DESIGN AND DEVELOPMENT ISSUES FOR EDUCATIONAL ROBOTICS TRAINING CAMPS

\author{
A THESIS SUBMITTED TO \\ THE GRADUATE SCHOOL OF NATURAL AND APPLIED SCIENCES \\ $\mathrm{OF}$ \\ MIDDLE EAST TECHNICAL UNIVERSITY
}

\author{
BY \\ MEMET ÜÇGÜL
}

IN PARTIAL FULFILLMENT OF THE REQUIREMENTS

FOR

THE DEGREE OF DOCTOR OF PHILOSOPHY

IN

COMPUTER EDUCATION AND INSTRUCTIONAL TECHNOLOGY

MAY 2012 
Approval of the thesis:

\section{DESIGN AND DEVELOPMENT ISSUES FOR EDUCATIONAL ROBOTICS TRAINING CAMPS}

submitted by MEMET ÜÇGÜL in partial fulfillment of the requirements for the degree of Doctor of Philosophy in Computer Education and Instructional Technology Department, Middle East Technical University by,

Prof. Dr. Canan Özgen

Dean, Graduate School of Natural and Applied Sciences

Prof. Dr. Soner Yildırım

Head of Department, Computer Edu. and Inst. Tech.

Prof. Dr. Kürşat Çağıltay

Supervisor, Computer Edu. and Inst. Tech. Dept., METU

\section{Examining Committee Members:}

Prof. Dr. Soner Yıldırım

Computer Education and Instructional Tech. Dept., METU

Prof. Dr. Kürşat Çağıltay

Computer Education and Instructional Tech. Dept., METU

Assoc. Prof. Dr. Erdinç Çakıroğlu

Elementary Education Dept. METU

Assist. Prof. Dr. Çiğdem Haser

Elementary Education Dept. METU

Assist. Prof. Dr. Erol Özçelik

Computer Engineering Dept. Atılım Univesity

Date: 04 May 2012 
I hereby declare that all information in this document has been obtained and presented in accordance with academic rules and ethical conduct. I also declare that, as required by these rules and conduct, I have fully cited and referenced all material and results that are not original to this work.

Name, Last name: Memet Üçgül

Signature: 


\title{
ABSTRACT \\ DESIGN AND DEVELOPMENT ISSUES FOR EDUCATIONAL ROBOTICS TRAINING CAMPS
}

\author{
Üçgül, Memet \\ Ph.D., Computer Education and Instructional Technology \\ Supervisor: Prof. Dr. Kürşat Çağıltay \\ May 2012, 278 Pages
}

The aim of this study is to investigate the critical design and development issues for educational robotics training camps. More specifically, the purpose of the study is to explore and describe critical design issues for educational robotics training camps, illustrating how each factor affects robotic camps and enlightening how these factors should be implemented for the design of a robotic training camp. For this purpose, two robotic training camps were organized with elementary school students. Thirty children attended the first camp and twenty two children attended to the second one.

The research design was qualitative in nature, more specifically; multiple-case design approach was used. Interviews with children and instructors, observations, field notes, and camp evaluation forms were the data collection methods. The data were analyzed through the qualitative data analysis techniques. The data were categorized under emerged themes, learning outcomes, evaluation of the camps' components, career, group issues, competition, coaching, technical issues, challenges and camp duration.

Some prominent findings of the study are; the instruction strategy for a robotics camp should be designed from simple to complex. The most effective and liked part of the camps are project studies, therefore projects studies should be encouraged at robotic camps. Robotics training camps should give chance to practice to the children 
what they have learned at schools. The group size should be arranged that every child in the group should have duties at any time.

The study was concluded with a robotics camp design guideline and a sample robotic training camp curriculum.

Key Words: Robotics Training Camp, Design Issues, STEM, Robotic Camp Curriculum. 


\title{
$\ddot{O Z Z}$
}

\section{EĞİTSEL ROBOT KAMPLARININ TASARIMI VE GELISTTİRILMESİ}

\author{
Üçgül, Memet \\ Doktora, Bilgisayar ve Öğretim Teknolojileri Eğitimi Bölümü \\ Tez Yöneticisi: Prof. Dr. Kürşat Çağgltay \\ Mayıs 2012, 278 Sayfa
}

Bu tez çalışmasının temel amacı, ilköğretim düzeyindeki çocuklar için tasarlanacak eğitsel robot kamplarının tasarım ve geliştirme ile ilgili kritik konularını incelemektir. Daha açık bir ifade ile, eğitsel robot kampları için başarıya etki eden faktörlerin belirlenmesi, bu faktörlerin kamp başarısına olan etkisi ve bu faktörlerin başarılı bir kamp için nasıl kullanılması gerektiğini ortaya koymaktır. Bu amaçla, ilköğretim öğrencilerine yönelik iki adet eğitsel robot kampı hazırlanmış ve gerçekleştirilmiştir. Birinci kampa otuz, ikinci kampa ise yirmi iki öğrenci katılmıştır.

Bu çalışma nitel bir çalışmadır. Daha detaylı belirtmek gerekirse, bu çalışmada çoklu durum çalışması yaklaşımı kullanılmıştır. Katılan öğrenciler ve eğitmenlerle gerçekleştirilen görüşmeler, gözlem, alan notları ve değerlendirme formları veri toplama araçları olarak kullanılmıştır. Nitel veri analizi yöntemleri kullanılarak veriler değerlendirilmiştir. Veriler açığa çıkan öğrenme kazanımları, kamp bölümlerinin değerlendirilmesi, kariyer, grup konusu, rekabet, koçluk, teknik konular, zorlanmalar ve kamp süresi temaları altında toplanmıştır.

Çalışmanın bazı öne çıkan bulguları şunlardır; kamp eğitiminde basitten karmaşığa giden bir yapı izlenmelidir, en etkili en beğenilen çalışma proje çalışmasıdır, bu nedenle bir robot kampında proje çalışmaları mümkün olduğunca uygulanmalıdır. Eğitsel robot kampları öğrencilere okullarda öğrendikleri bilgileri uygulayabilme 
olanağı sunmalıdır. Grup büyüklüğü her katılımcının, grup çalışmasına aktif olarak katılmasını sağlayacak büyüklükte olmalıdır. Çalışma her bir kritik faktör için tasarım ve geliştirme önerileri ve bu önerilerin uygulandığ örnek bir robot kampı müfredatı ile sonuçlandırılmıştır.

Anahtar Kelimeler: Eğitsel Robot Kampı, Tasarım Konuları, FTMM, Robot Kampı Müfredat1. 
To real two incidents of life; death and birth

To Uncle Halil, we miss you so much And Ahmet Demir, we love you so much 


\section{ACKNOWLEDGMENTS}

This study was a long long journey. I could not finish this journey without contributions of some special people. Firstly, I want to express my special thanks to my dear advisor Prof. Dr. Kürşat Çağıltay who proposed the study and he have always supported me on this journey. I am very grateful for your constructive criticism, punctual feedbacks, guidance and advice. Secondly, I would like to thank to Prof. Dr. Soner Yıldırım and Assoc. Prof. Dr. Erdinç Çakıroğlu for being in my committee. They gave final shape to this study with valuable and supportive advice. Thirdly, I would like to express my deepest gratitude to Assist. Prof. Dr. Çiğdem Haser for her friendly welcome and explanations about qualitative methodology. Without her, I could not understand qualitative methodology so deeply and I could never prepare evaluation forms of the study.

My dearest friend Mahmut Teker, you are more than a friend for me, you are my brother. I will never forget your support on this journey. I do not want to think about how I could achieve this dissertation without you.

My dearest another friend Öner Uslu, I know that at two o'clock you were still working on my data for cross-case analysis. I would like to express my deepest gratitude to you for your support.

Also special thanks to Assist. Prof. Dr. Aslihan Osmanoğlu, your fresh experience on qualitative methodology shed light on my paths. Millions thanks for sharing your experience with me.

I would love to thank Erol Özçelik, Nihan Ocak, Sinem Taşlı, Gamze Türkmen, Selin Deniz Uzunosmanoğlu, Nuri Kara and Bengisu Çağıltay. Without your support we could not conduct the both camps. I would also like to thank to Assist. Prof. Dr. Pelin Yüksel for observations during the pilot studies, Assist. Prof. Dr. Aslı Bugay for her valuable supports and Fatih Açıkgöz for helping me transcription of the interviews. 
Also, special thanks to all TEGV's staff primarily Olçum Kavruk, Gönül Çaltı, Rasim Erkan and Nilüfer Demirkan. You changed my life when I became a volunteer, like you changed millions of children.

I could not possibly forget to thank to my family. They supported me during the writing process of this dissertation and most importantly they stand me while I felt the pressure of the study. 
TABLE OF CONTENTS

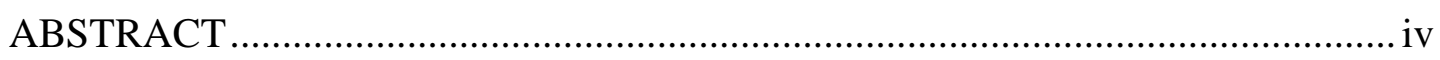

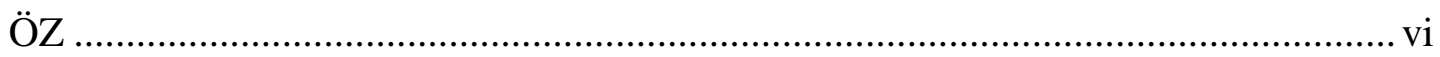

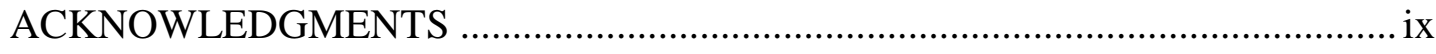

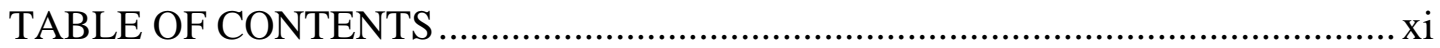

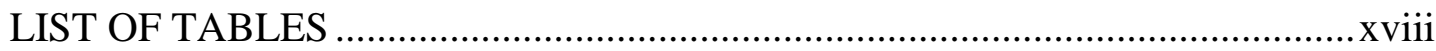

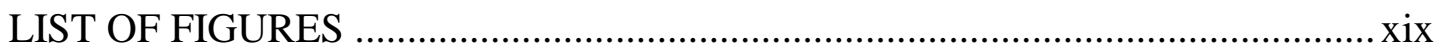

CHAPTERS

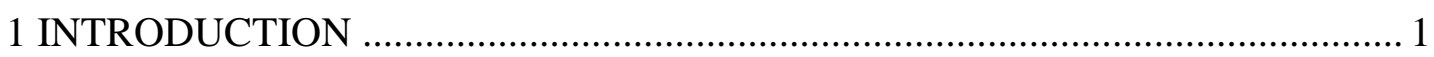

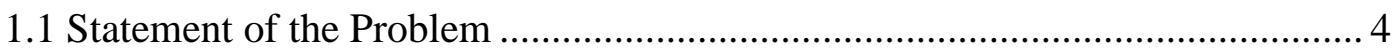

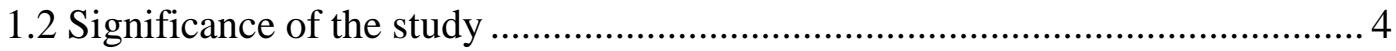

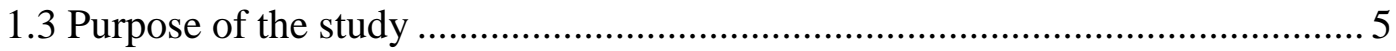

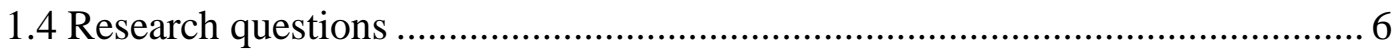

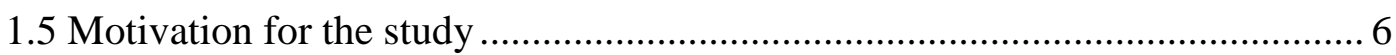

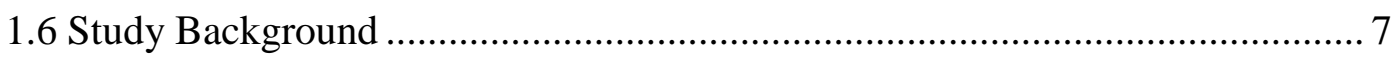

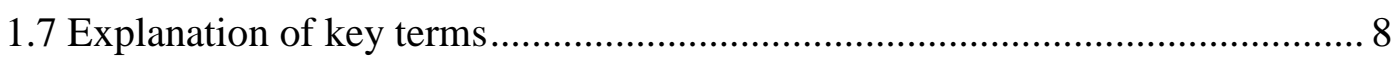

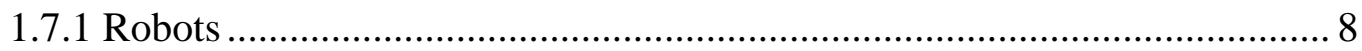

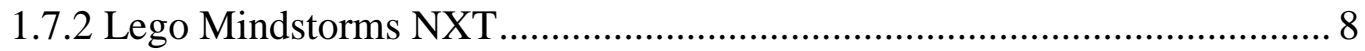

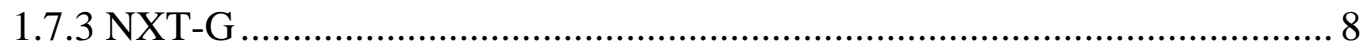

1.7.4 STEM (Science, Technology, Engineering, Mathematics) ........................ 9

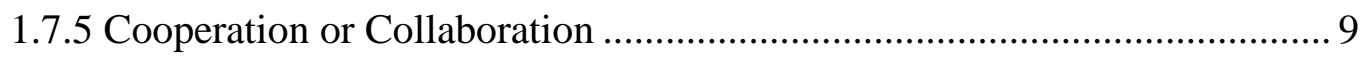

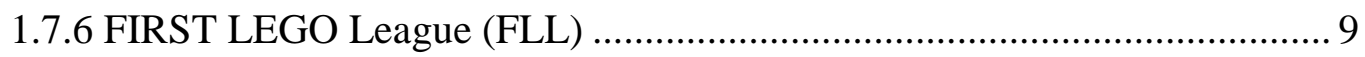

1.7.7 Educational Volunteers Foundation of Turkey (TEGV) .......................... 10

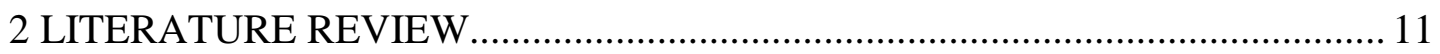

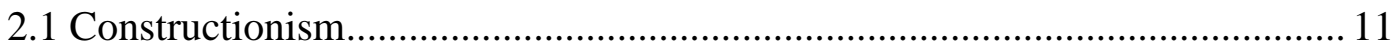

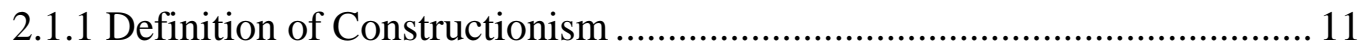

2.1.2 Constructionism, Constructivism Similarities and Differences................ 12

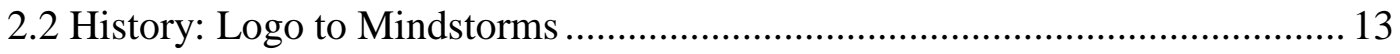


2.2.1 What is Logo

2.2.2 Lego/Logo ......................................................................................... 14

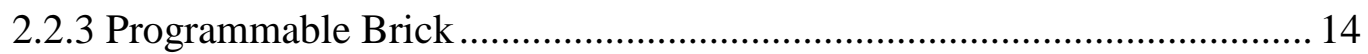

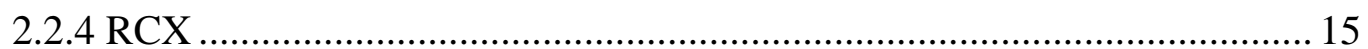

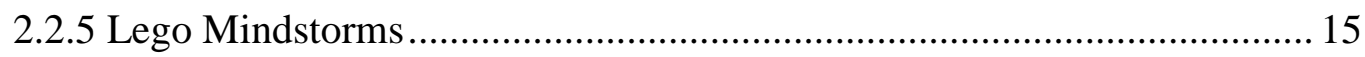

2.3 STEM (Science, Technology, Engineering and Mathematics) Education........ 17

2.3.1 Definition .......................................................................................... 17

2.3.2 STEM Education in Turkey …………………………......................... 18

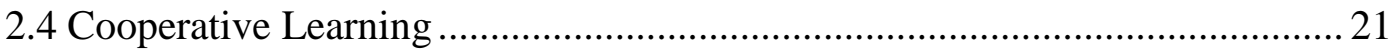

2.4.1 Competitive, Individualistic and Cooperative Learning ............................ 21

2.4.2 Basic Elements of Cooperation................................................................. 22

2.4.3 Cooperative Learning and Robotics ………………………………........ 25

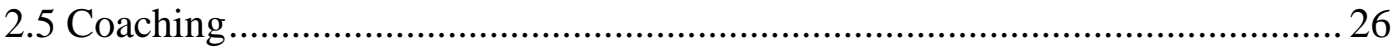

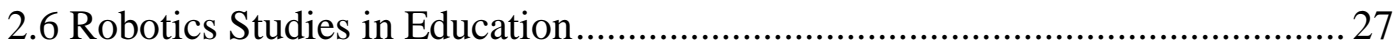

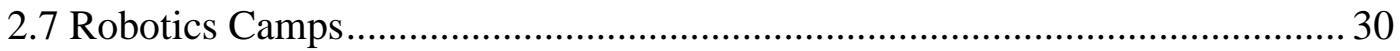

2.8 Summary and the Gaps in the Literature........................................................ 31

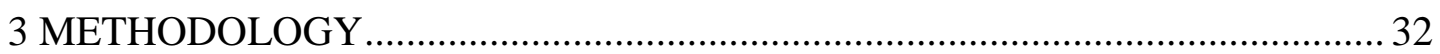

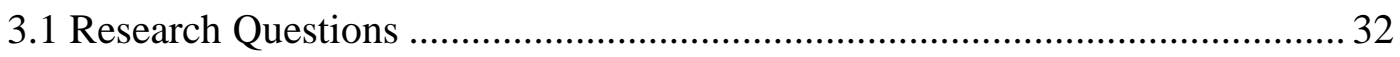

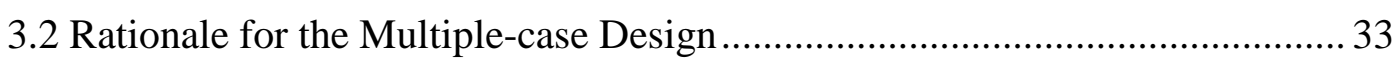

3.3 Study Related Concepts and Issues ............................................................ 34

3.3.1 Young inventors build robots and discover science project ....................... 34

3.3.2 The educational volunteers foundation of Turkey (TEGV): ...................... 35

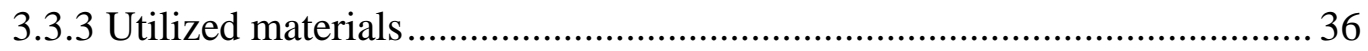

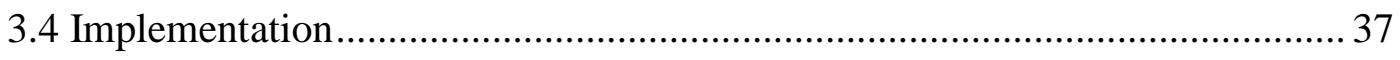

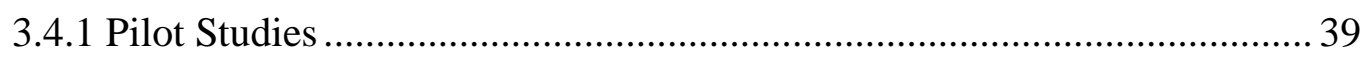

3.4.2 The first camp instructors meeting ……………………........................ 40

3.4.3 Practice of the camp............................................................................ 40

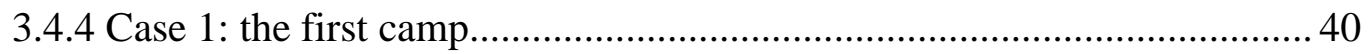

3.4.5 The second camp instructors meeting ....................................................... 41

3.4.6 Case 2: the second camp ......................................................................... 41

3.5 Data Collection Procedure................................................................................ 41

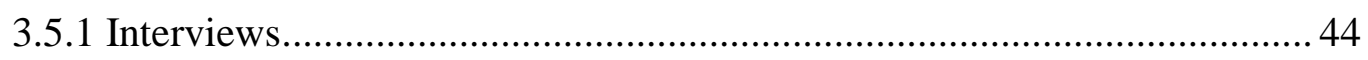

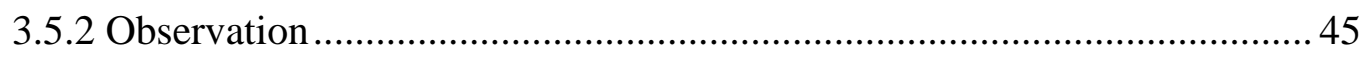

xii 


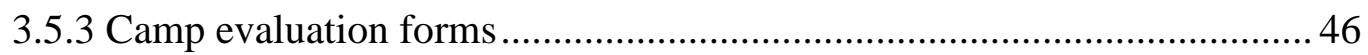

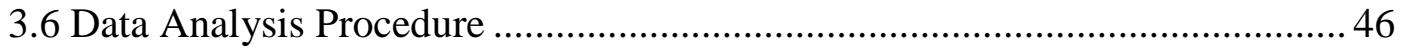

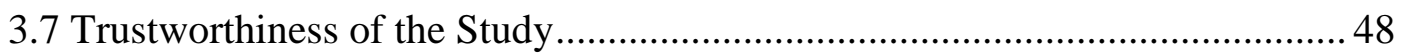

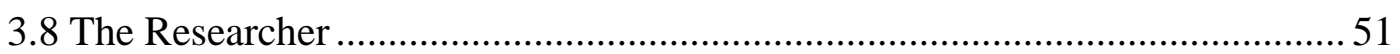

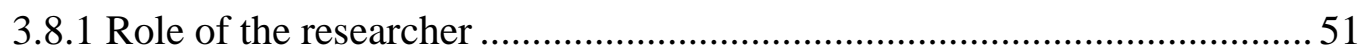

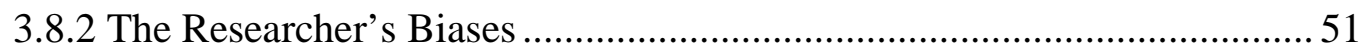

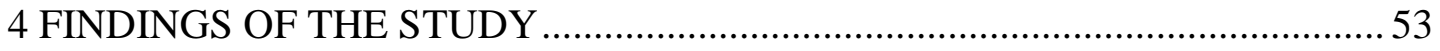

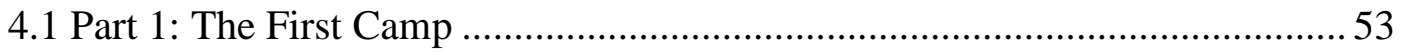

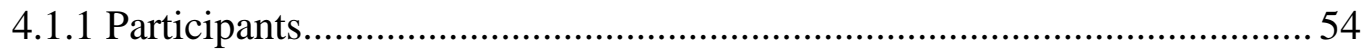

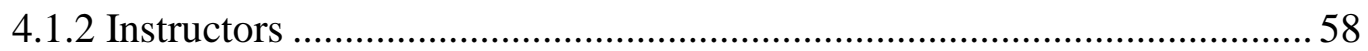

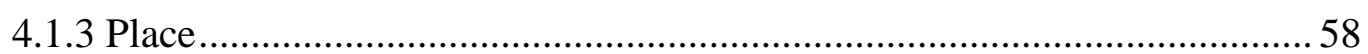

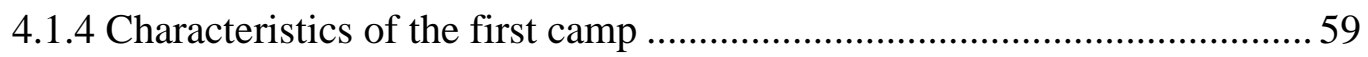

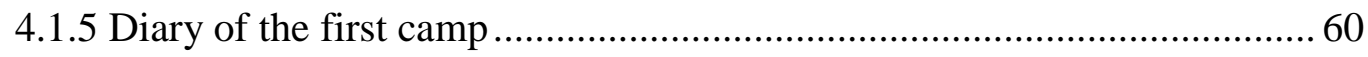

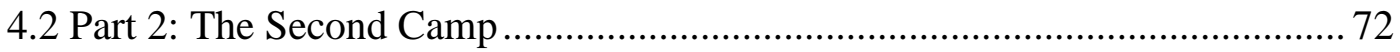

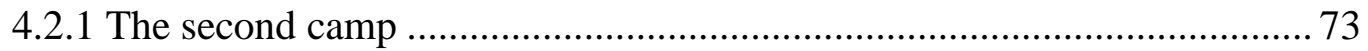

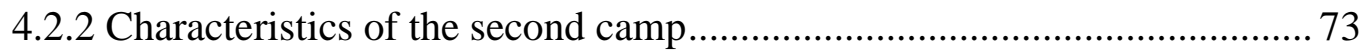

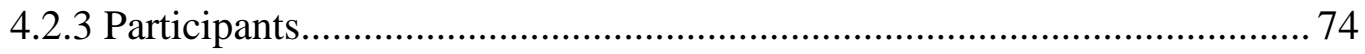

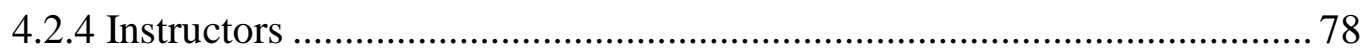

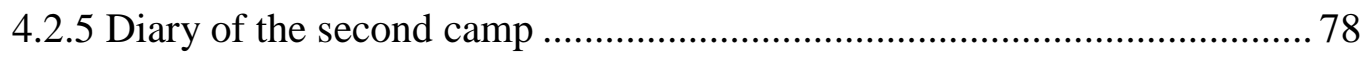

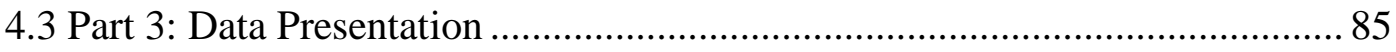

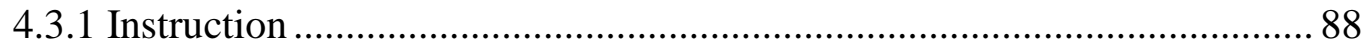

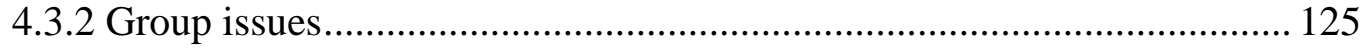

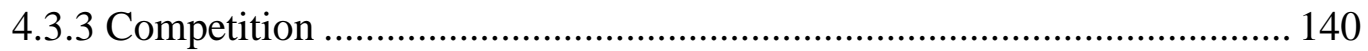

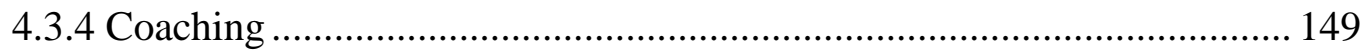

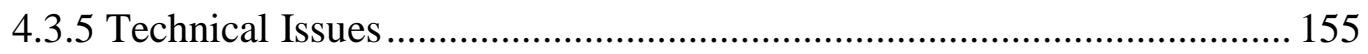

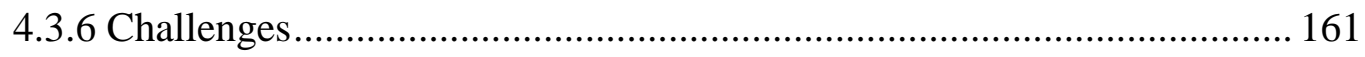

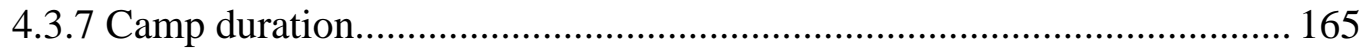

4.3.8 Summary and design principles ........................................................... 169

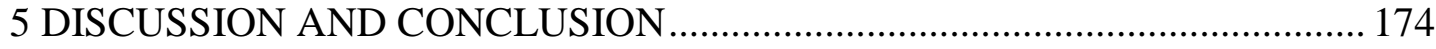

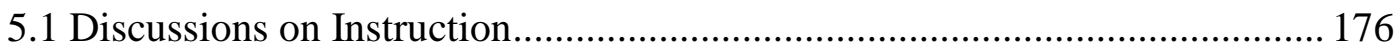

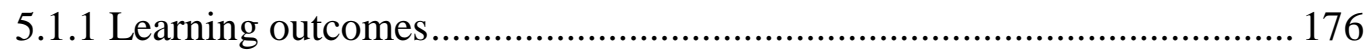

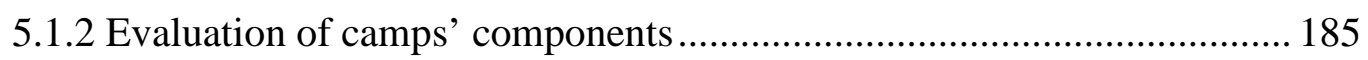

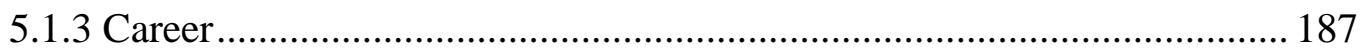

xiii 


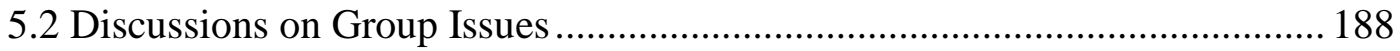

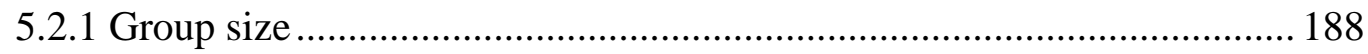

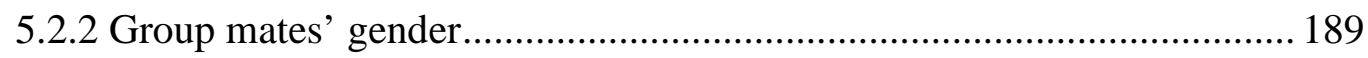

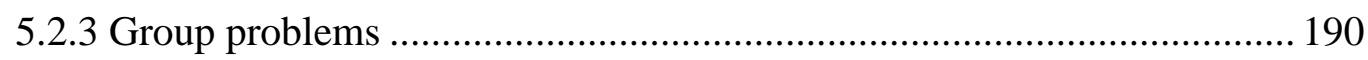

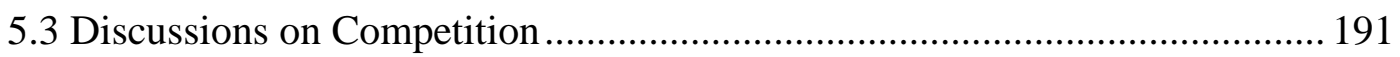

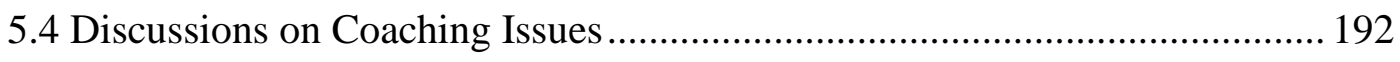

5.5 Discussions on Technical Issues ................................................................ 193

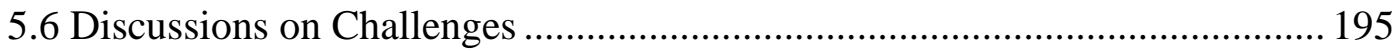

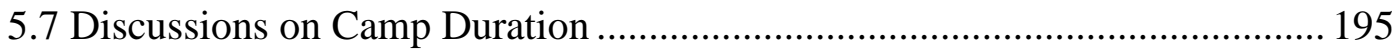

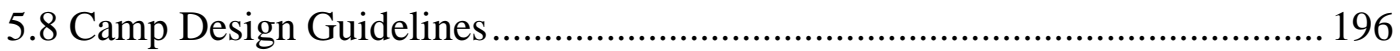

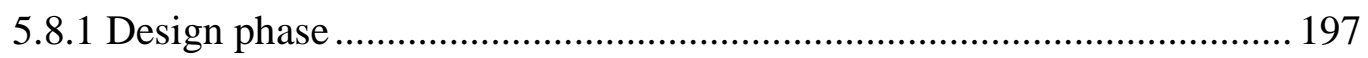

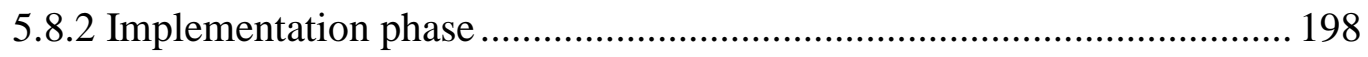

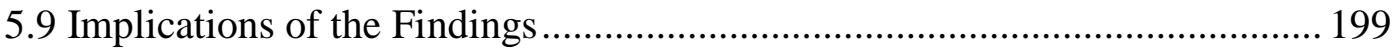

5.10 Recommendations for Future Research ................................................... 199

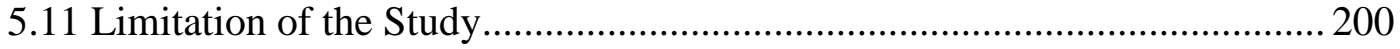

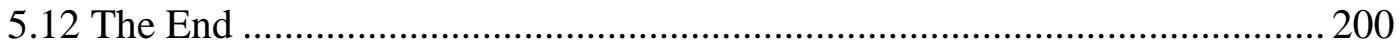

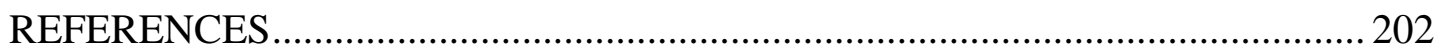

APPENDICES

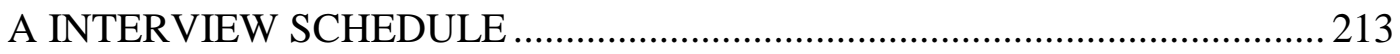

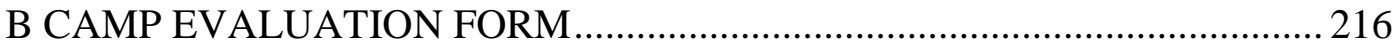

C RESEARCH PERMISSION ........................................................................ 217

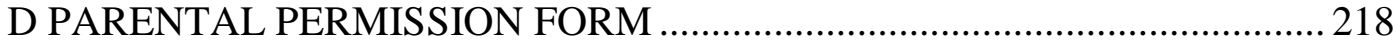

E THE FIRST CAMP CURRICULUM .......................................................... 220

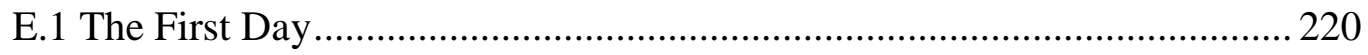

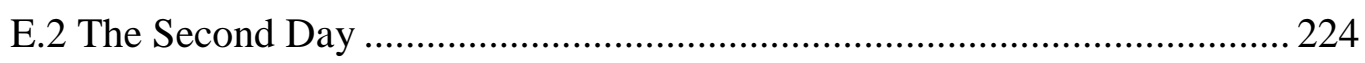

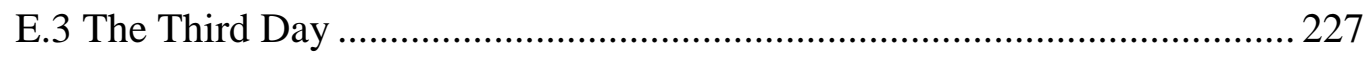

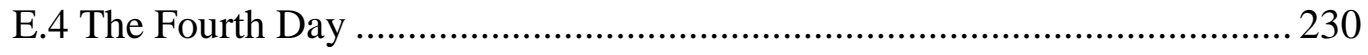

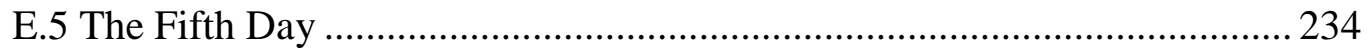

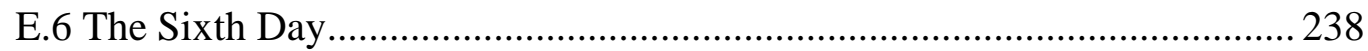

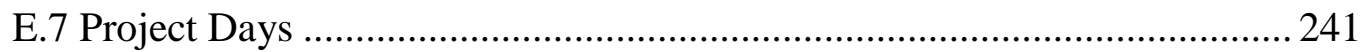

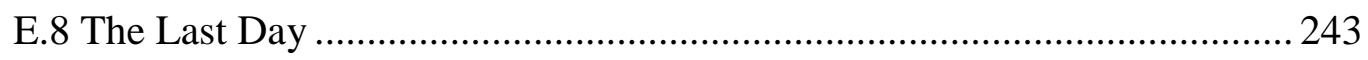

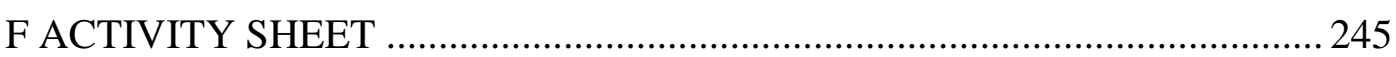

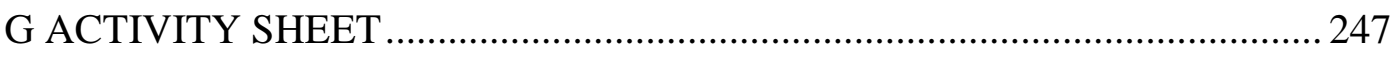

xiv 


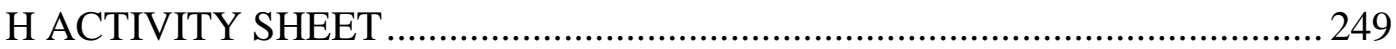

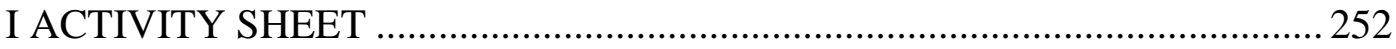

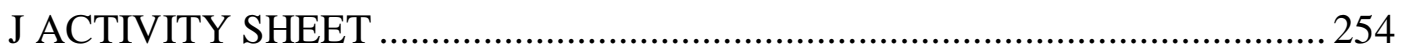

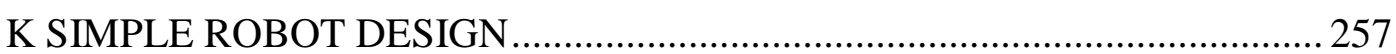

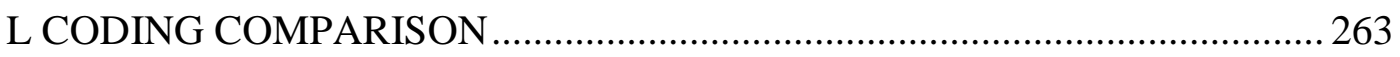

M SAMPLE ROBOTICS CAMP CURRICULUM …………………………........ 268

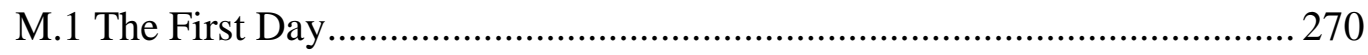

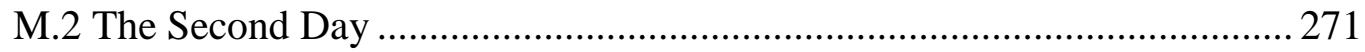

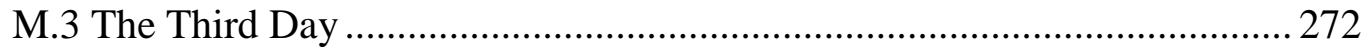

M.4 The Fourth, Fifth and Sixth Days............................................................ 272

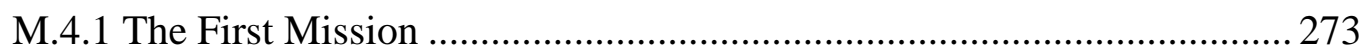

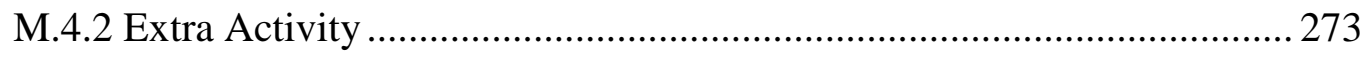

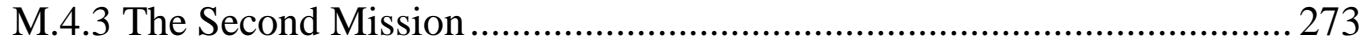

M.4.4 The Third Mission.......................................................................... 275

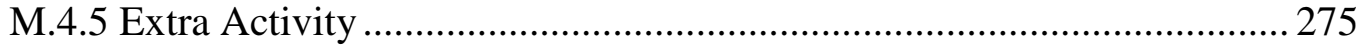

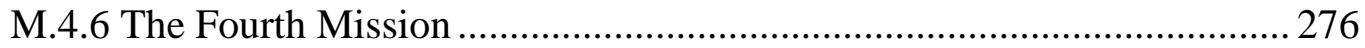

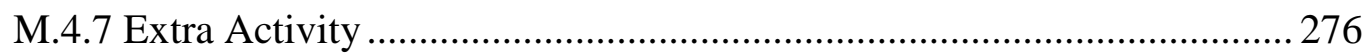

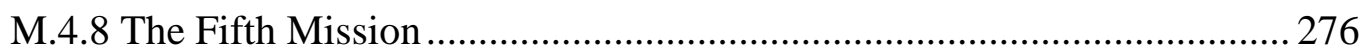

M.5 The Seventh, Eighth and Ninth Days ………………………………...... 276

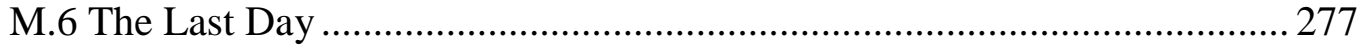

M.7 Extra Activity - Tournament................................................................... 277

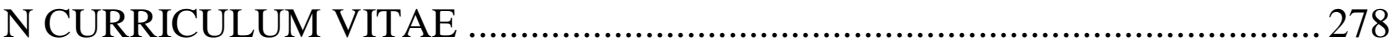




\section{LIST OF TABLES}

\section{TABLES}

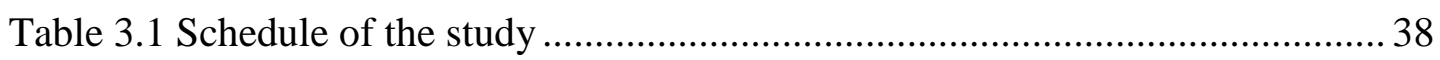

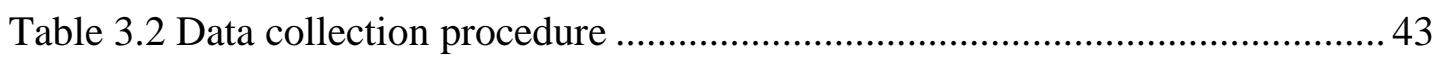

Table 4.1 Gender and grades of the second camp's participants ..............................54

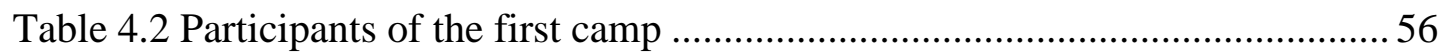

Table 4.3 Gender and grades of the second camp's participants .............................. 58

Table 4.4 Gender and grades of the second camp's participants .............................. 74

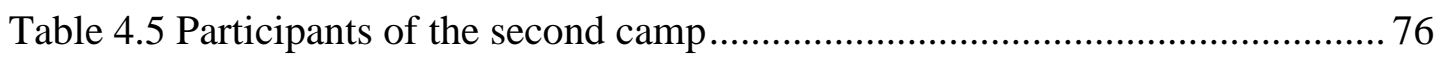

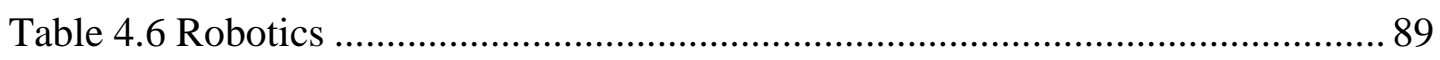

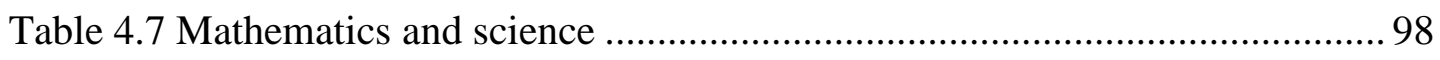

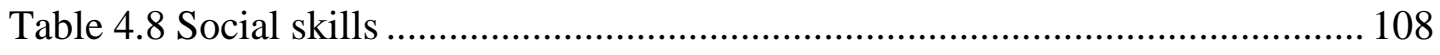

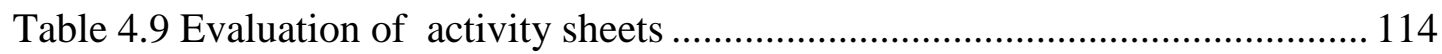

Table 4.10 Evaluation of the second camps' components ..................................... 117

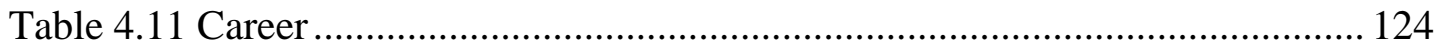

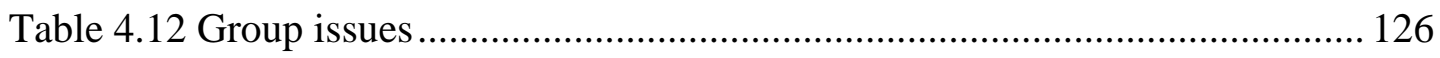

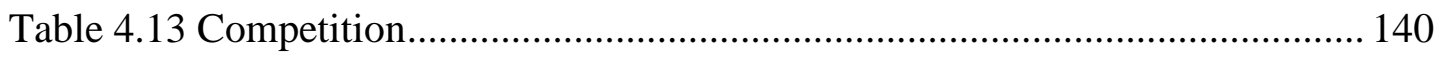

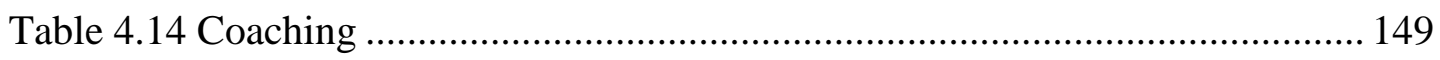

Table 4.15 Consequences of coaching approach .................................................. 151

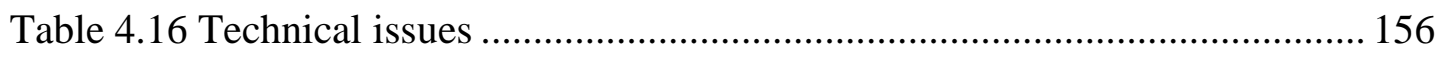

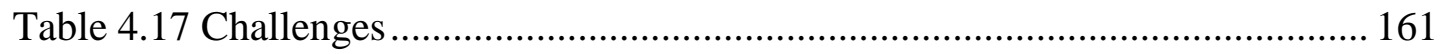

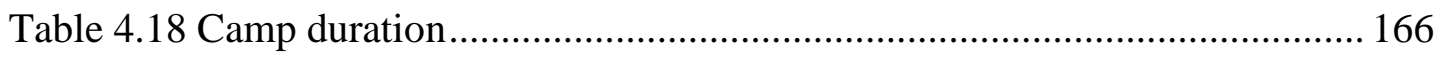

Table 4.19 Design principles for an educational robotics training camp................. 170

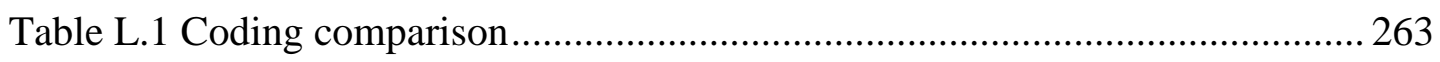




\section{LIST OF FIGURES}

\section{FIGURES}

Figure 2.1 Components of LEGO Mindstorms NXT ........................................... 16

Figure 3.1 LEGO Mindstorms NXT programming environments NXT-G .............. 37

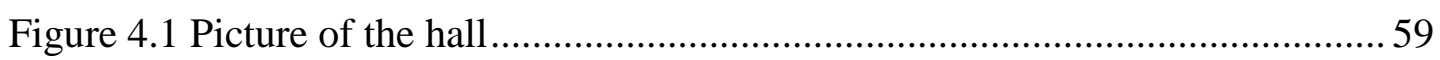

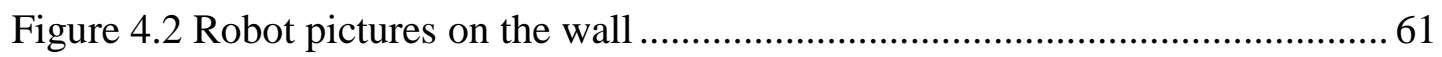

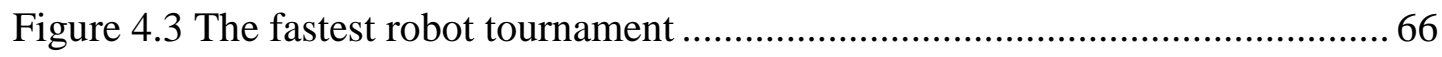

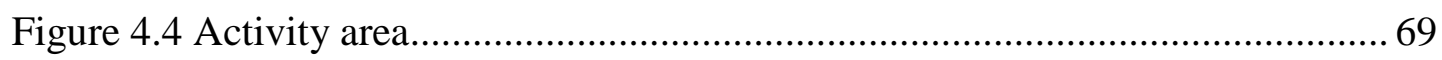

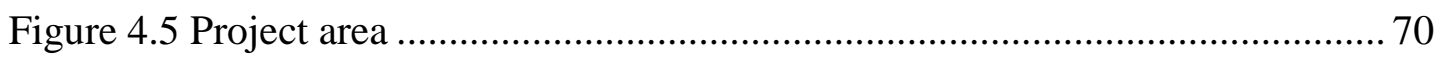

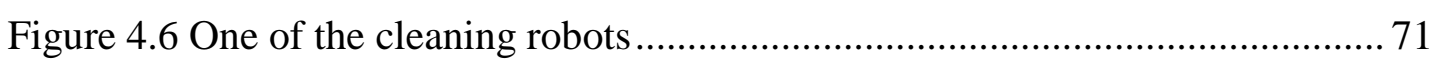

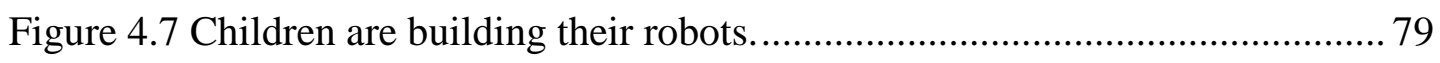

Figure 4.8 Children are working at a learning station.......................................... 81

Figure 4.9 One of the projects: irrigation robot .................................................. 83

Figure 4.10 One of the groups presenting their robot project .................................. 85

Figure 4.11 Concept map of the themes and categories......................................... 87

Figure 5.1 Concept map of the themes and categories.......................................... 175

Figure E.1 Yaz1 yazan robot..................................................................... 221

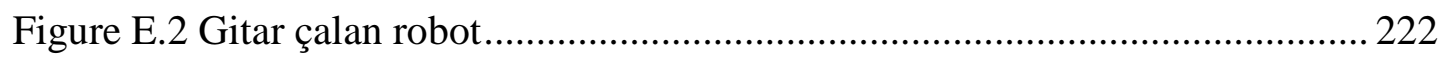

Figure E.3 Matematik problemi çözen robot ........................................................ 222

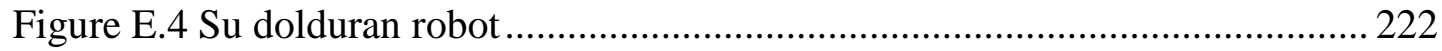

Figure E.5 Güvenlik robotu hirsızı yakalarken .................................................. 225

Figure E.6 Güvenlik robotu ultrasonik sensörü ile nesnelerin uzaklığını ölçerken . 236

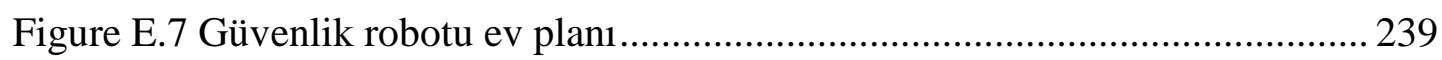

Figure E.8 Finished simple robot design......................................................... 257

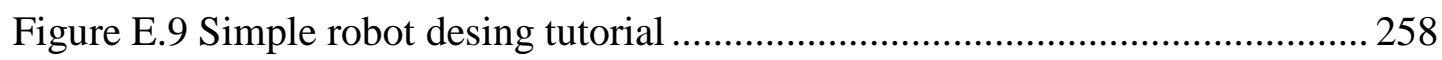

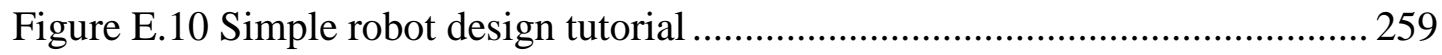

Figure E.11 Simple robot design tutorial ............................................................ 260

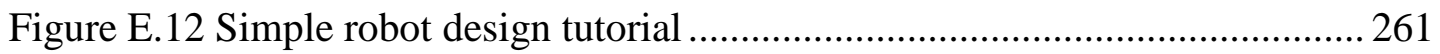




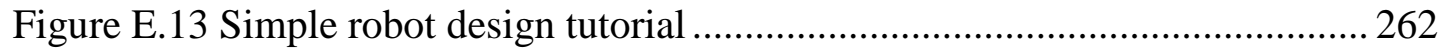

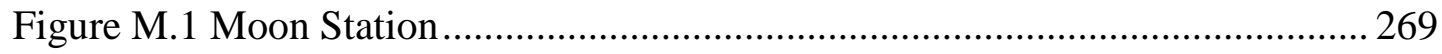

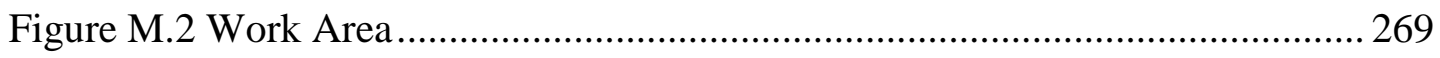

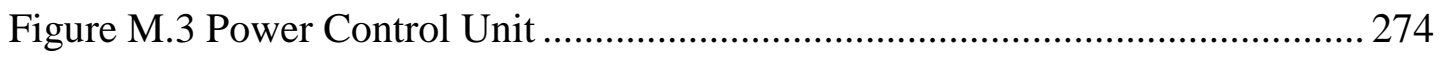

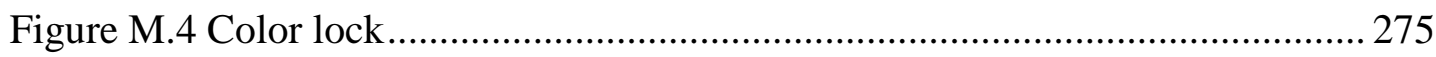




\section{CHAPTER 1}

\section{INTRODUCTION}

Background of the study rooted to study of Dr. Seymour Papert who is known as the founding father of Logo. Papert believes that children are innately gifted learners and it is possible to design computers therefore learning how to communicate with computer can be a natural process, like learning French by living in France (Papert, 1993). Papert and his students' research on introducing children to the computer world and bringing programming in to their physical world resulted creation of logo programming environment in 1967 (McNerney, 2004; McWhorter, 2005). Logo was computer language which communication with the Turtle which is basketball sized, dome shaped robot. Turtle could move across the floor by Logo commands like FORWARD, BACKWARD, LEFT and RIGHT; and made drawings on butcher paper with mounted pen (Martin, Mikhak, Resnick, Silverman, \& Berg, 2000; Papert, 1993; Watt, 1982).

Logo has been used by tens of millions of school children all over the world. Its theoretical background known as constructionism influenced educators and researchers direction of educational reform and roles of the technology in education (Kafai \& Resnick, 1996). The simplest definition of the constructionism is "learning by making" (Papert \& Harel, n.d.). Constructionism includes "learning by doing" which is the idea behind constructivism and goes far beyond it (Papert, 1993, 1999).

When personal computers had become common in the school, the floor turtle was expensive and unreliable for school setting. In 1970s the turtle migrated to computer screen. Screen turtle was more accurate and much faster than the floor turtle that 
allow children to create and examine more complex geometric shapes (Martin et al., 2000; McNerney, 2004; Sargent, 1995; Sargent, Resnick, Martin, \& Silverman, 1996; Watt, 1982).

Although the screen turtle was more practical, it added some abstraction and may have caused difficulties for some children (McNerney, 2004). In the mid-1980s collaboration with Lego group created Lego/Logo system which is combination of Lego Technic product (which includes beams, gears, and motors) and Logo language. Therefore, the turtle was of the screen and turned back to the real world. Children can build their own machines such as a Ferris wheel, elevator, and robot creature before programming them (Martin, 1988; Martin et al., 2000; Sargent, 1995; Sargent et al., 1996; Watt, 1982).

Lego/Logo had mobility limitation; the machine had to be connected to computer with wires. Fred Martin (1988) and his research group have overcome this deficiency by first Programmable Bricks in 1987. The Programmable Brick had a computer inside, therefore downloaded program can be executed without connecting to a computer (Sargent, 1995; Sargent et al., 1996).

Randy Sargent (1995) and his colleagues created second generation Programmable Bricks (Gray Brick and Red Brick). Red Brick and its field works would be basis for the development of the Lego RCX Brick which shares many common features with the MIT Red Brick (Martin et al., 2000; Mindell et al., n.d.).

In 1998, the Lego Company released a new product called the LEGO Mindstorms Robotic Invention Kit consisting of 717 pieces including LEGO bricks, motors, gears, different sensors, and a RCX Brick which contains three input ports and three output ports attached to a Hitachi H8/3292 micro controller (McWhorter, 2005; Mindell et al., n.d.).

First-generation Lego Mindstorms kit (the name comes from Seymour Papert's groundbreaking book (Martin et al., 2000)) was replaced with Lego Mindstorms NXT kit in 2006. Lego Mindstorms NXT kit consists of 577 pieces, including: 3 servo motors, 4 sensors (ultrasonic, sound, touch, and light). The kit also includes 
NXT-G, a graphical programming environment that enables the creation and downloading of programs to the NXT.

Although, robots have been playing an active role in education since LOGO Turtle (Papert \& Harel, n.d.), in recent years, interest in using robots for educational purposes has been increased. International robots championships such as RoboCup, First Lego League, and RoboFesta have taken the interest of primary and secondary schools administrators and students. Some researchers investigated instructional values of these competitions (Griffith, 2005; Petre \& Price, 2004; Welch, 2007). Wilczynski and Flowers (2006) found that involvement of robot contests offer some additional educational benefits such as; motivating student creativity, self-directed learning, developing teamwork and communication skills; fostering interest in science and technology.

Many universities and schools prepare technology and robotic related summer schools for children (Cannon et al., 2006; Cannon, Panciera, \& Papanikolopoulos, 2007; Keathly \& Akl, 2007; Nordstrom, Reasonover, \& Hutchinson, 2009; Williams, Ma, Prejean, \& Ford, 2008). Some of the technology related camps were prepared especially for girls to increase their curiosity and interest toward STEM (Science, Technology, Engineering and Mathematics) and also increase the possibilities of the engineering careers (Burket, Small, Rossetti, Hill, \& Gattis, 2008).

Robotic and STEM relations are not limited with the study of STEM careers. Robotics became the new approach to provide students with hands on experience while learning science subjects (Jim, 2010). For example, Barker and Ansorge (2007) investigated the effectiveness of science and technology curriculum based on robotics on the achievement scores of the children ages 9-11 in a 4-H program. (4-H is the largest out-of-school youth program sponsored by the Department of Agriculture in the United States. 4-H stands for Head, Heart, Hands and Health (National Institute of Food and Agriculture, n.d.)). Williams et al. (2008) stated that the summer robotics camp enhanced middle school students physics content knowledge, Mataric, Koenig, and Feil-Seifer (2007) concluded that robotics has been proved that a superb tool for hands-on learning, not only of robotics itself, but also general science, technology, engineering, and mathematics (STEM). 


\subsection{Statement of the Problem}

Robots' educational potential as teaching tools and motivators has long been recognized by educators, but economic constrains prohibited its extensive deployment. However, in the past few years cost of the robots has been decreased and their performance has been increased. Nowadays, robots are affordable, powerful and reliable to be deployed in college and even high schools. With the popularity of international robot championship, educational usage of the robots has accelerated recently.

There are some researchers also their experience and gave information about how they conducted their robotics camp. Murphy and Rosenblatt (2000) expressed their robotic camp and in the appendices section they present a daily teaching syllabus and information on appropriate videos, applicable robotics Web sites, and commercial robot kits. Moreover, Nourbakhsh et al. (2005) from Carnegie Mellon University, The Robotics Institute, offered the curriculum of their course Robotic Autonomy which is a seven week, hands on introduction to robotics design for high school students with daily plan. However, these studies were not conducted with Lego Mindstorms NXT sets and they did not offer any suggestions for successful robotics instructional camp, they just presented their curriculums.

Therefore, the popularity of educational usage of the robotics requires defining success factors for an instructional robotics camp. Moreover, inexperienced camp designers need to know the success factors, how these factors affect their camp and more importantly they need a guideline for an instructional robotics camps. Because the literature of instructional robotics camps design is very limited, this study aimed to fill this gap in the literature of instructional robotics studies.

\subsection{Significance of the study}

Papert (1993) stated that robots are excellent tools to implement constructivist theory into practice. The children can imagine themselves in the place of the robots and understand how robots interpret the programs and behave according to that program. Papert believe that programmable robots are flexible and powerful to be able to embody ideas which are previously had no real-world analogy. 
Using robotic activities in some engineering courses at elementary, middle and high school level has gained popularity (Nordstrom et al., 2009). Some organizations have been preparing team based robotic competitions ("BEST," n d, "FIRST LEGO League, FLL" n d, "National Robotics Challenge," n d). FLL competitions have been arranged for thirteen years to increase interest to science technology, engineering and mathematics (STEM) to teach teamwork and to grow children's creativity. Some universities and corporations have designed robotic programs to provide an introductory approach to robotics.

Results of some studies have shown that robotics are perfect tools to teach STEM subject and hands on experience (Jim, 2010; Mataric et al., 2007). Recently, there are increasing attentions toward robotics to improve teaching of STEM and they seem as innovative tools for STEM education. National Science Board, (2010) emphasizes engineering as a field that critical to innovation and exposure to engineering activities such as robotics and invention competitions can spark further interest in STEM.

Outputs of this study will contribute to the literature on robots in technology related learning. Teachers who may want to use robots to enrich their classes can benefit from the result of this study. The result of the study could enlighten their path how to implement robotic activities in classroom settings such as mathematics and science courses.

Any organization or corporation who want to prepare robotic programs, camps, and activities can benefit from the findings of the study. Therefore, they could have some insights before preparing their curriculum and they prepare their curriculum according to the findings and conclusion of this study.

\subsection{Purpose of the study}

The purpose of the study is to reveal the design principles for an educational robotics training camp. More specifically, to determine the factors those affect success of a robotics training camp and with the light of these factors, to determine design principles for an educational robotics training camp. To serve this purpose, two robotic training camps were organized and conducted with secondary school 
students. Case study approach which is a qualitative inquiry to explain, describe, illustrate and enlighten to a phenomenon within its real context (Yin, 2009) was chosen as research method. Because the purpose of the study is explaining and describing critical factors for design and development of an educational robotics training camp, illustrating how each factor affects success of the camp and enlightening how these factors should be implemented for a successful robotic training camp; case study approach was chosen.

\subsection{Research questions}

Driving research question of the study is:

- What are the key design and development principles for an educational robotics training camp?

And, the sub research questions are:

In a robotic camp:

- How should the instruction be structured?

- What are the group and gender issues?

- What are the issues and strategies about cooperation and competition among learners?

- How should coaching be provided? What are the successful coaching strategies and issues?

- What are the technical issues and strategies for a successful training camp?

\subsection{Motivation for the study}

The researcher was a volunteer instructor of The Educational Volunteers Foundation of Turkey (Türkiye Eğitim Gönüllüleri Vakfı, TEGV) at Semahat - Dr. Nüsret Arsel Education Park. He was working with six, sixth grade kids on "informatics seagulls" projects. They have just finished their project; manager of the education park offered them a new fascinating project; going in FLL (First Lego League) robotics competitions. They would be the first FLL team of the education park. 
During this study, the researcher and his team attended FLL twice and they were the winner of robot performance at our district in the second year. When the camps had started, the researcher had nearly two years robotics experiences.

While preparing FLL tournament with six unique children, The researcher had chance to observe them while they were creating solutions to challenging tasks and their enjoyment from the process. Working and observing them let the researcher's interest in pursuing a more rigorous study of a creating robotic camp curriculum and guideline.

As a $\mathrm{PhD}$. student and a research assistant the researcher always believe that results of the educational studies should have effects on the educational system or outputs of the educational studies should somehow have impact on the students. That is the reason why he has been a volunteer at TEGV, because, he wants to do something that directly related with students and their learning. Designing a robotic camp, working with the children and witnessing their learning also excited him toward this study.

\subsection{Study Background}

While coaching the FLL team of the park, the researcher and colleagues conducted two pilot studies at the education park. The pilot studies conducted during summer and fall semesters of 2009. The first study lasted four week long with four hours a week; the second was eight week long with two hours a week and conducted at weekends. During the pilot studies, a co-researcher observed children and educational activities were evaluated. Moreover, the researcher gained experiences about target group, educational robotics activities and LEGO Mindstorms NXT sets and programming environments.

After the pilot phases, actual data were collected from two ten days long robotics camps. The camps were supported by The Scientific and Technological Research Council of Turkey (TÜBİTAK). First camp was implemented between 25th January and 5th February of 2010 during the semester holiday. The second camp was implemented between 12th and 23th July of 2010. Both camps were implemented at The Educational Volunteers Foundation of Turkey (Türkiye Eğitim Gönüllüleri Vakfı, TEGV) Semahat - Dr. Nüsret Arsel Education Park. 


\subsection{Explanation of key terms}

The following definitions describe the key terms which are used in this study. These terms are explained in order to provide clear understanding and avoid ambiguity in the interpretation of the phenomenon and the findings.

\subsubsection{Robots}

Robot Institute of America (1982) defines a robot as "a programmable, multifunctional manipulator designed to move objects through variable programmed motions to perform a variety of tasks"(cited in Argote \& Goodman, 1984, p. 1). During the camps, the much simple and related to children life definition of the robots were used. "A robot is a device that is built to independently perform actions and interact with its surroundings. In a nutshell, a robot should be able to move and react all on its own. If you are controlling its actions, it's just a remote-controlled toy" (Kelly, 2010, p. 1).

\subsubsection{Lego Mindstorms NXT}

Lego Mindstorms NXT is a programmable robotic kit, the second generation of Lego's Mindstorms product line, released in 2006 (Ferrari \& Astolfo, 2007). The LEGO Mindstorms NXT kits consist of a central block (the NXT), a set of sensors (touch, ultra sonic, sound and light), 3 servomotors, and a wide selection of LEGO building pieces (including gears, wheels and structural pieces). The NXT contains a 32-bit ARM7 microcontroller, 3 output ports (for motors), 4 input ports (for sensors), a USB port, a loudspeaker, 4 buttons, a display and Bluetooth wireless communication ("Mindstorms: What is NXT," n.d.).

\subsubsection{NXT-G}

NXT-G is the programming software that comes bundled with Lego Mindstorms NXT. It has a graphical programming environment therefore programming is simple and fun by dragging and dropping the code blocks. Each code blocks (represented by icons) describe different behaviors and connect them with lines to describe program behavior (Ferrari \& Astolfo, 2007). 


\subsubsection{STEM (Science, Technology, Engineering, Mathematics)}

The acronym STEM stands for Science, Technology, Engineering, and Mathematics. "STEM Education is an interdisciplinary approach to learning where rigorous academic concepts are coupled with real world lessons where students apply science, technology, engineering, and mathematics in contexts that make connections between school, community, work, and global enterprise enabling the development of STEM literacy and with it the ability to compete in the new economy" (Tsupros, Kohler, \& Hallinen, 2009, p. 10).

\subsubsection{Cooperation or Collaboration}

Even though there are many parallels between cooperation and collaboration, some researchers emphasize their difference. In cooperation "partners split the work, solve sub-tasks individually and then assemble the partial results into the final output" (Dillenbourg, 1999, p. 8). According to Webb \& Palincsar (1996) in collaboration "the thinking is distributed among the members of the group" (p. 848) and “collaborative learning is generally assumed to subsume cooperation" (p. 848). However, some researcher emphasize ambiguity about the meaning of collaborative learning and states these two terms (cooperative learning and collaborative learning) usually used as synonym and intractable (Johnson \& Johnson, 1996). In this study these two terms will be used interchangeably and the meaning of small group of children working together to achieve shared goals and maximizes their learning.

\subsubsection{FIRST LEGO League (FLL)}

FIRST LEGO League (FLL) is offered by FIRST (For the Inspiration and Recognition of Science and Technology) to inspire middle school students toward science and technology and get kids excited about it. The competition is for ages 914 (up to 16 outside of the U.S. and Canada), and utilizes theme-based challenges to engage kids in research, problem solving, and engineering. The completion has two parts the projects and the robot game ("FIRST LEGO League," n.d.; Lau, Tan, Erwin, \& Petrovic, 1999). 


\subsubsection{Educational Volunteers Foundation of Turkey (TEGV)}

Educational Volunteers Foundation of Turkey (TEGV) was founded in January 23, 1995 by Suna Kıraç with the aim of supporting the primary education provided by the government (Kirac, 2006). The objective of this nonprofit organization is "to create and implement educational programs and extracurricular activities for children aged 7-16, so that they can acquire skills, knowledge and attitudes supporting their development as rational, responsible, self-confident, peace-loving, inquisitive, cognizant, creative individuals, who are against any kind of discrimination, respect diversity and are committed to the basic principles of the Turkish”(“About TEGV," n.d.). 


\section{CHAPTER 2}

\section{LITERATURE REVIEW}

Chapter two provides an overview of the theoretical background and a review of the related literature about robotic studies in education. In this chapter, firstly constructionism -theoretical background of the study- will be introduced. Then, the historical evaluation of LEGO Mindstorms will be presented. Later, the current situation of STEM Education in Turkey will be explained. Next cooperative learning issues, and the studies related to LEGO Mindstorms in educational settings will be summarized.

\subsection{Constructionism}

\subsubsection{Definition of Constructionism}

In the 1960s, Seymour Papert and colleagues initiated a research projects at Massachusetts Institute of Technology (MIT), to understand how children think and learn. They invented the programming language and philosophy of education which is Logo. Logo has been used by tens of millions of school children all over the world. Its theoretical background influenced educators and researchers direction of educational reform and roles of the technology in education. That theoretical background is known as constructionism (Kafai \& Resnick, 1996).

Papert worked with Piaget at late 1950's and early 1960's in Switzerland, and he stated that "in 1964, after five years at Piaget's Center for Genetic Epistemology in Geneva, I came away impressed by his way of looking at children as the active builders of their own intellectual structures" (Papert, 1993, p. 19). Papert built his theory of learning on the constructivist theories of Jean Piaget, stating that learning is 
active construction of the knowledge in the learner's mind, knowledge is not simply transmitted from teacher to student. In addition to constructivist theory, Papert constructed his learning theory based on artificial intelligence theories and gender and personality studies (Harel, 1991).

Papert makes the simplest definition of the constructionism as "learning by making" (Papert \& Harel, 1991). He adopted the word constructionism refer to everything that related to "learning by making" and the idea behind constructionism includes and goes far beyond the idea of "learning by doing", that is the idea behind constructivism (Papert, 1999). Seymour Papert and Idit Harel made following definition of constructionism in the first chapter of their book Constructionism.

Constructionism--the $\mathrm{N}$ word as opposed to the $\mathrm{V}$ word-shares constructivism's connotation of learning as "building knowledge structures" irrespective of the circumstances of the learning. It then adds the idea that this happens especially felicitously in a context where the learner is consciously engaged in constructing a public entity, whether it's a sand castle on the beach or a theory of the universe (Papert \& Harel, 1991, p. 1).

\subsubsection{Constructionism, Constructivism Similarities and Differences}

As stated in the previous paragraphs, Piaget and Papert are both constructivists. They viewed children as the builders of their own knowledge. Knowledge is not merely an asset to be transmitted, encoded, grasped, retained but constructed and reconstructed through personal experience. Learning means the creating of concepts and rules through an active process of doing and thinking (Ackermann, 2001; Harel, 1991).

According to Ackermann (2001), Piaget and Papers are also both developmentalists which means they have common idea on incremental knowledge construction. They both studied the condition in which learners' theories about a given phenomenon and relation with a specific period of time. However, Papert in his book Mindstorms Children, Computers, and Powerful Ideas (1993) stated that he does not fully accept Piaget's distinction concrete thinking and formal thinking but he accepts that this distinction close enough to reality. Piaget believed that computer can concretize (and 
personalize) the formal thinking. Therefore, computer can allow us to shift the boundary separating concrete and formal thinking.

Constructionist view sees children as the active builder of their knowledge rather than passive receiver of the knowledge from teacher, as in constructivist view, however constructionist view adds extra emphasis to "external artifact" and "sharing with others" (Kafai \& Resnick, 1996; Maxwell, 2006). "Unlike Piaget, Papert believe that learning as particularly effective when it takes place in the context of a rich and concrete activity, which the learner (child as well as adult) experiences while constructing a meaningful product such as a piece of artwork, a story, or a research report. Therefore, he creates and emphasizes far richer learning environments than does Piaget in his experiments" (Harel, 1991, p. 26). While accepting the Piaget's cognitive stages, "Papert is interested in how learners engage in a conversation with [their own or other people's] artifacts, and how these conversations boost selfdirected learning, and ultimately facilitate the construction of new knowledge" (Ackermann, 2001, p. 1). He stresses the importance of tools, media, and context in human development (Ackermann, 2001; Harel, 1991).

\subsection{History: Logo to Mindstorms}

\subsubsection{What is Logo}

After returning to the United States, Seymour Papert founded MIT Artificial Intelligence Laboratory with Marvin Minsky. Early work of the Papert with his research group included the development of the Logo programming language. First version of Logo was created in 1967. Logo was computer language which communicate with the Turtle. Turtle was wastebasket-sized computer-controlled cybernetic animal. Turtle made drawings on butcher paper with mounted pen. Turtle was commanded by children's Logo program (Martin et al., 2000; Papert, 1993; Watt, 1982). According to Papert (1993) turtle served as an "object-to-think-with" 
A first encounter often begins by showing the child how a Turtle can be made to move by typing commands at a keyboard. FORWARD 100 makes the Turtle move in a straight line a distance of 100 Turtle steps of about a millimeter each. Typing RIGHT 90 causes the Turtle to pivot in place through 90 degrees. Typing PENDOWN causes the Turtle to lower a pen so as to leave a visible trace of its path while PENUP instructs it to raise the pen. Of course the child needs to explore a great deal before gaining mastery of what the numbers mean. But the task is engaging enough to carry most children through this learning process (Papert, 1993, p.11).

Most popular version of logo has floor turtle. In 1970s the turtle migrated to computer screen. Screen turtle was more accurate and much faster than the floor turtle that allow to children to create and examine more complex geometric shapes. Some turtle shapes can change shape to birds, cars, planes or whatever the designer chooses (Martin et al., 2000; Sargent et al., 1996; Watt, 1982).

\subsubsection{Lego/Logo}

In the mid-1980s Logo research group began to collaboration with Lego group. They created Lego/Logo system which is combination of Lego Technic product (which includes beams, gears, and motors) and Logo language. Therefore, the turtle was of the screen and turned back to into the world. However, lego/logo was different from the earlier floor turtle. Lego/logo was not already built mechanical object. Children can build their own machines such as a Ferris wheel, elevator, and robot creature before programming them. Children did not restrict to the turtles (Martin et al., 2000; Sargent et al., 1996; Watt, 1982).

In the late 1980s, Lego/logo system became commercially available. It was sold to schools with the name "LEGO tc logo" by the Lego group. It was used more than 15.000 elementary and middle schools in the United States (Martin et al., 2000; Sargent et al., 1996; Watt, 1982).

\subsubsection{Programmable Brick}

Lego/Logo had limitations. The machines constructed by children had to be connected to computer with wires. When children used Lego/Logo to create mobile 
machines, wires limited its mobility. Wires got tangled with other objects in the environments also they restrict the range of machines. Each motors and sensors should be connected to the computer with their own cable. Therefore, they get twisted in knots as the machine rotates. Moreover, it was difficult to think Lego/Logo machine as an autonomous while it was attached to a computer (Martin et al., 2000; Sargent et al., 1996). Fred Martin (1988) and his research group have overcome this deficiency by first Programmable Bricks in 1987. The Programmable Brick had a computer inside, therefore to program the Programmable Brick you first write the program on the computer, and then download the program to the Programmable Brick via a cable. Then, the brick can be disconnected from the computer. The program stored on the brick and the brick can be carried anywhere and the program can be executed without connected to a computer (Sargent et al., 1996).

\subsubsection{RCX}

From 1992 to 1996 Randy Sargent and his colleagues created second generation Programmable Bricks (Gray Brick and Red Brick). Fieldwork with tree classroom usage of Red Brick were resulted some design upgrades at size, LC screen, and Logo programming environment. The idea of putting Logo statements as blocks (called Logo Blocks) serves as the basis for the Lego Group later commercial usage. Red Brick and its field works would be basis for the development of the Lego RCX Brick which shares many common features with the MIT Red Brick (Martin et al., 2000; Mindell et al., n.d.). In their article "Building and Learning with Programmable Bricks", Sargent and colleagues listed twenty things to do with a programmable brick, inspired on Papert and Solomon's (1971) memo called Twenty things to Do with a Computer.

\subsubsection{Lego Mindstorms}

In 1998, the Lego Company released a new product called the LEGO Mindstorms Robotic Invention Kit consisting of 717 pieces including LEGO bricks, motors, gears, different sensors, and a RCX Brick which contains three input ports and three output ports attached to a Hitachi H8/3292 micro controller (McWhorter, 2005; 
Mindell et al., n.d.). Lego Company believed in robot design concept so strongly that they gave the name of Seymour Papert's book (Martin et al., 2000).

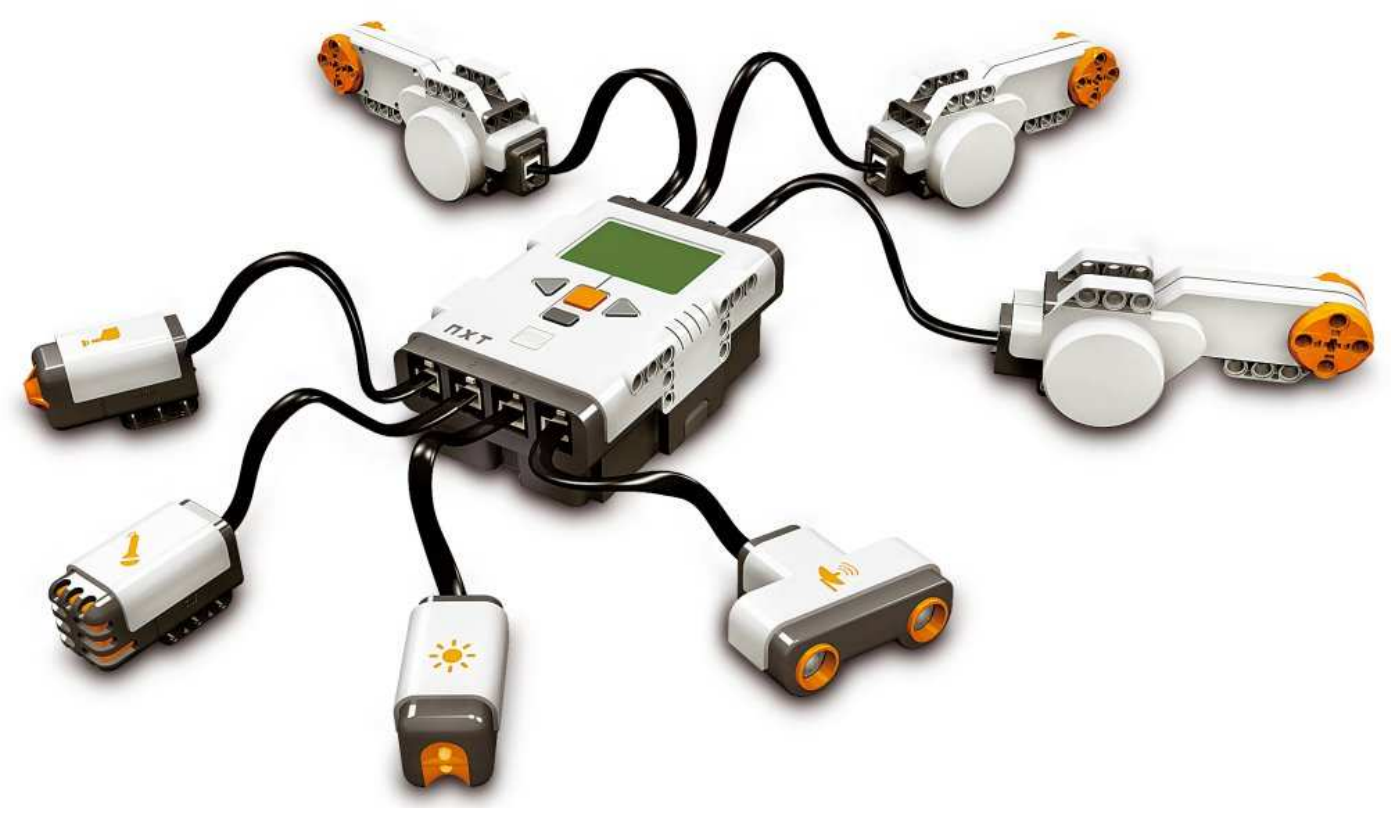

Figure 2.1 Components of LEGO Mindstorms NXT

First-generation Lego Mindstorms kit was replaced with Lego Mindstorms NXT kit in 2006 (Figure 2.1). At the heart of the system is NXT brick which is a multipurpose controller that interfaces easily with a development or graphics computer. The main processor of the NXT is a 32-bit Atmel ${ }^{\circledR}$ ARM ${ }^{\circledR}$ processor operating at $48 \mathrm{MHz}$, with $256 \mathrm{kB}$ flash memory and $64 \mathrm{kB}$ RAM; an 8-bit, $8 \mathrm{MHz}$ co-processor provides additional functionality. It has four-button interface and a 100 x 64 pixel (26 x 40.6 mm) LCD display. It can communicate with a desktop or laptop computer with the integral USB 2.0 port (12 Mbit/s) or the wireless Bluetooth port, based on the singlechip CSR BlueCore ${ }^{\mathrm{TM}} 4$ ("Lego Mindstorms NXT Hardware Developer Kit," n.d.). In addition to the NXT brick, Lego Mindstorms NXT kit consists of 577 pieces, including: 3 servo motors, 4 sensors (ultrasonic, sound, touch, and light). The kit also 
includes NXT-G, a graphical programming environment that enables the creation and downloading of programs to the NXT.

\subsection{STEM (Science, Technology, Engineering and Mathematics) Education}

\subsubsection{Definition}

Common understanding from STEM education that the integration of science, technology, engineering, and mathematics concepts in the curriculum (Scott, 2009). According to Ohio STEM Learning Network definition STEM is greater than the sum of its parts,

STEM is an acronym for Science, Technology, Engineering, and Mathematics, but what it teaches is far greater than the sum of its parts. Critical thinking learned through STEM education is applied across all disciplines, from the humanities through everyday problem solving and, of course, higher-level science (Ohio STEM Learning Network, n.d.).

Tsupros Kohler and Hallinen (2009) also emphasize interdisciplinary approach of STEM Education.

"STEM Education is an interdisciplinary approach to learning where rigorous academic concepts are coupled with real world lessons where students apply science, technology, engineering, and mathematics in contexts that make connections between school, community, work, and global enterprise enabling the development of STEM literacy and with it the ability to compete in the new economy" (p.10).

Robotics became the new approach to teach STEM subjects with hands on experience (Jim, 2010). Mataric, Koenig, and Feil-Seifer, (2007) asserted that robotics has been proved that a superb tool for hands-on learning, not only of robotics itself, but also general science, technology, engineering, and mathematics (STEM). Increasing attention has been paid to developing innovative tools for improved teaching of STEM, including trough robotics as a solution the current shortage of students' interest in STEM topics. Moreover, Natioanl Science Board, (2010) sees engineering is a field critical to innovation and exposure to engineering activities such as robotics and invention competitions can spark further interest in 
STEM. (Robotics studies to encourage interest to STEM topics are given in "Robotic Studies in Education" section of this chapter).

\subsubsection{STEM Education in Turkey}

In Turkish K-12 education system, STEM education should be investigated with three separate courses which are Science and Technology (Fen ve Teknoloji), Mathematics (Matematik) and Technology and Design (Teknoloji ve Tasarım).

\subsubsection{Science and Technology}

In 2004, Turkish Ministry of Education has prepared a new elementary school (grades 1 through 8) curriculum. Ministry of National Education - Board of Education (Milli Eğitim Bakanlığı Talim Terbiye Kurulu Başkanlığı - TTKB) evaluated inspectors' and teachers' report from 79 cities and reveled problems of science curriculum at 2000 (TTKB, 2006). With the light of this evaluation, technology dimension added to science curriculum and class hours increased 3 to 4 at a week (Tuysuz \& Aydin, 2009).

Vision of the new science and technology curriculum is to raise all students independent from individual differences as science and technology literate. For this purpose; The Board of Education (2006) stated the characteristics of the new science curriculum as based on constructivist approach, enriched with teaching activities and multiple assessment methods and techniques, it has seven learning areas with four content strands and there is a spiral approach for each strand. The seven learning areas are the following:

1. Physical Processes

2. Life and Living Beings

3. Matter and Change

4. The Earth and the Universe

5. Science Process Skills (SPS)

6. Science-Technology-Society-Environment (STSE)

7. Attitudes and Values (AV) 


\subsubsection{Mathematics}

New mathematics curriculum has been developed and is being implemented for primary and secondary schools with the curricula change in 2004 in Turkey.

The Vision of the newly developed Mathematics curriculum is stated as training individuals who can be able to use the mathematics in their lives, solve problems, share their solutions and ideas, work in groups and who enjoy learning mathematics (TTKB, 2009).

Newly developed mathematics curriculum is different from the old one by some aspects (TTKB, 2005). New mathematics curriculum;

- follows a conceptual approach, therefore the students could understand and embody mathematics with the help of their institutions and experiences.

- is based on the idea of the students should actively participate their learning process.

- gives opportunities to the students to express their abilities and individual differences via projects and homework,

- provides environments where the students could research, discover and discuss to solve problems.

- gives opportunities to develop the students psychomotor abilities via materials and activities.

- gives opportunities the students an education that appropriate for the environment they live in via activities adaptable to different periphery environments.

\subsubsection{Technology and Design}

Handcraft (İş Eğitimi) course was replaced with Technology and Design course at 2006 - 2007 education year (Şık \& Koç, 2011). Vision of the course is training individuals who can be able to realize the problems, create solutions, build ideas and share their solution, know how to learn, inquisitorial, entrepreneur, creative and imaginative (TTKB, 2006b). 
The curriculum consists of three parts which are system, fiction and production. With its spiral structure these three parts repeats $6^{\text {th }}, 7^{\text {th }}$ and $8^{\text {th }}$ grades $($ TTKB, 2006b). Characteristics of the new technology and design curriculum are:

- The program was prepared for students' development stage, interest, ability, needs and expectation.

- It is suitable to spiral approach

- It has common competencies with other Board of Education accepted and published courses (elementary education Turkish, Social studies, Mathematics, Science and Technology).

- It has been based on student-centered approach which made students as an active participant and individual investigator in practice.

- It contains class, group and individual activities aimed to parts' focal points.

- It contains biographies of scientists and inventors, innovation and invention stories in order to develop self-confidence, to look at situations from different angles.

- It contains activities that aimed to stimulate students' creativity before in class activities.

- It has a flexible structure because it will be shaped by students' individual expectations, needs and interests.

- It provides formative evolution as well as summative one.

\subsubsection{Current Status of Science and Mathematics Education in Turkey}

The PISA (Programme for International Student Assessment) evaluates the quality, equity and efficiency of school systems by evaluation of 15-year-old school pupils' scholastic performance. It is repeated every three years by the Organization for Economic Co-operation and Development (OECD) (OECD, 2010).

According to the result of the PISA 2003, Turkey was $28^{\text {th }}$ country between 40 attending countries with mean score of 423 at mathematics, 434 at science and 441 at reading. These scores were statistically significantly lower than the OECD countries' mean (MEB, 2005). 
In 2006 , Turkey was $44^{\text {th }}$ country at science, $43^{\text {th }}$ country at mathematics and $38^{\text {th }}$ country at reading between 57 countries. The mean scores of the Turkish pupils' were 424 at science, 424 at mathematics and 447 at reading. These scores were also statistically significantly lower than the OECD countries' mean (MEB, 2007).

PISA 2009 results was not different than the previous ones, Turkey was $43^{\text {th }}$ country at science and mathematics and $41^{\text {th }}$ country at reading with mean score of 445 at science, 454 at mathematics and 464 at reading between 65 countries. Although little increase at the scores between 2003 and 2009 years, the rank of Turkey did not change and Turkey is still statistically significantly lower than the OECD countries' mean (OECD, 2010).

With the reform on elementary education curriculum in 2004, Ministry of the Education emphasized information and communication technologies to visualize and deepen the understanding of concepts (Ersoy, 2006). However, results of PISA scores show that there should be much more innovative support mechanism for STEM education in Turkey.

\subsection{Cooperative Learning}

\subsubsection{Competitive, Individualistic and Cooperative Learning}

In the competitive classroom setting, each student studies against to other students in the classroom to achieve a goal that only one or few students can achieve. Students are graded on a norm-referenced grading, in which students should work faster more accurately than the others. Students' achievement based on the other students' failure. Therefore, in competitive classroom only a few can be successful (Johnson \& Johnson, 1984, 1996). In competitive settings, they strive to better than their peers, work to take away others, celebrates classmates' failures, think resources are limited, recognize their negatively linked fate, and believe only the strong one will be successful (Johnson, Johnson, \& Hulubec, 1986). Most of the students perceive school as a competitive enterprise. They either work hard to do better than the others or they take it easy because they do not believe that they have a chance to be successful (Johnson \& Johnson, 1984). 
In the individualistic learning settings, students work alone on learning goals independent from the goals of the other students. Individual goals are assigned each day and students are evaluated according to fixed criteria (criteria-referenced grading). The success or failure of other students does not affect their score. Therefore, students are encouraged to focus on their strict self-interest, value only their own efforts and success, and view success or failure of others are irrelevant. They perceive that their achievements are unrelated with what the other students do (Johnson \& Johnson, 1984, 1996; Johnson et al., 1986).

Cooperation is defined as working together to achieve shared goals. In cooperative activities, each individual look for outcomes that beneficial to individual and to all other group members. Cooperative learning is the instructional use of small group therefore students work together to maximize their own and each other's learning. Unlike competitive settings, cooperative settings result in students striving for mutual benefit from each other's efforts, recognizing that all group members have common fate, knowing that one's performance is mutually caused by oneself and one's colleagues, and feeling proud and celebrating together for a group members' achievement. In cooperative learning settings, there is a positive interdependence among students' goal attainments; students realize that they can reach their learning goals if and only if the other students in the learning group also reach their goals (Johnson \& Johnson, 1996; Johnson et al., 1986).

\subsubsection{Basic Elements of Cooperation}

Structuring cooperative learning is more than grouping number of students which are sitting at the same table can freely talk each other and working on their own work. There is a difference between structuring students to work cooperatively and having students working in a group. There are five basic elements to accept a group work as a cooperative group learning (Johnson \& Johnson, 1984; Johnson et al., 1986).

- Clearly perceived positive interdependence

- Considerable promotive (face-to-face) interaction

- Clearly perceived individual accountability and personal responsibility to achieve the group's goals 
- Frequent use of relevant interpersonal and small-group skills

- Frequent and regular group processing of current functioning to improve future effectiveness.

\subsubsection{Positive Interdependence}

In the cooperative learning environments each students have two responsibilities: to learn the assigned materials and to be sure that all the members of the group also do it. This dual responsibility is called positive interdependence. Positive interdependence exists when one perceives that they are all linked with the group members in a way so that makes it impossible to be successful unless the entire group succeeds (and vice versa) and they must coordinate their efforts with the efforts of others to complete the task. When positive interdependence established in a group work, students realize the fact that (1) each group member's efforts are required and indispensable and (2) each group member has a unique contribution to success of the group (Johnson \& Johnson, 1996; Johnson et al., 1986). Johnson, Johnson and Smith (2007) divided positive interdependence into three categories: outcome, means, and boundary interdependence. First, when students are in cooperative or competitive situation, the students are directed to desired outcome; that is goal or reward. Goals can be real or imaginary. Goal interdependence includes goal, reward/celebration and fantasy. Second, means interdependence which is specifying the actions required on the part of group members includes overlapping resource, role, and task interdependence. Last, boundary interdependence includes environmental (i.e., different part of the room or different room), identity (which binds them together as an entity) and outside enemy (i.e., negative interdependence with another group) interdependence.

\subsubsection{Promotive Interaction}

Positive interdependence causes to the second essential component of cooperative learning; promotive interaction. Promotive interaction refers to students encourage and facilitate each other's efforts to complete tasks in order to achieve the group' goal. Promotive interaction causes to providing each other with efficient and effective help and assistance, exchanging needed resources, more efficiently and 
effectively information processing, providing feedback to each other to improve their subsequent performance, challenging each other's conclusion and reasoning to advance decision making and better understanding of the problem, encouraging each other for mutual goals, trusting group members and acting trustworthy ways, attempting to accomplish mutual benefit, and having a moderate level of arousal with low levels of stress and anxiety (Johnson \& Johnson, 1996, 2008; Johnson et al., 2007).

\subsubsection{Individual Accountability/Personal Responsibility}

The third essential component of cooperative learning is individual accountability. Individual accountability exists when the each individual's performance is assessed, the results given back to the individual and the group to compare against a standard of performance, and the member is held responsible by group mates for contributing his or her fair share to the group's success. It is also important that the group knows performance of the members, who needs more assistance, support, and encouragement in completing a task, just as it's important that group members know they cannot "hitchhike" on the work of others. Sometimes group members seek a free ride when it's difficult to identify individuals' contributions, when their contributions are redundant, or when all members are not responsible for the final group outcome (Johnson \& Johnson, 1996, 2008; Slavin, 1991).

\subsubsection{Interpersonal and Small-Group Skills}

The fourth essential component of cooperative learning is interpersonal and smallgroup skills. In cooperative learning groups, students learn academic subject matter as well as the interpersonal and small-group skills. Cooperative learning requires group members to master the small group and interpersonal skills they need to work effectively with each other and function as part of a group. If teamwork skills are not learned, academic goals cannot be achieved. The greater the members' teamwork skills, the higher the quality and quantity of their learning. This characteristic makes cooperative learning more complex than competitive and individualistic learning. In order to achieve mutual goals, students must (1) get to know and trust each other, (2) communicate accurately and unambiguously, (3) accept and support each other, and 
(4) resolve conflicts constructively (Johnson \& Johnson, 1996). However, the students do not instinctively know how to interact effectively with others. They must be taught the interpersonal and small-group skills required for high-quality collaboration and be motivated to use them.

\subsubsection{Group Processing}

The last essential component of cooperative learning is group processing. Group processing occurs when members discuss what member actions were helpful and unhelpful and make decisions about what actions to continue or change. The aim of group processing is to explain and improve group member's effectiveness to achieve the group's goals. Group processing could be achieved by enabling learning groups to focus on maintaining good working relationships among members, promoting the learning of cooperative skills, ensuring that members receive feedback on their participation, ensuring that students think about their metacognitive as well as their cognitive work, and providing a way to celebrate the success of the group and reinforce group members' positive behaviors (Johnson \& Johnson, 1996; Johnson et al., 2007).

\subsubsection{Cooperative Learning and Robotics}

Robotics provide an environments that encourages and promotes small group learning and interaction (McGoldrick \& Huggard, 2004). Denis and Hubert (2001) reported activity based on collaborative and problem-based learning in educational robotics environments called "educational robotics". They developed educational robotics activities at primary and secondary school levels. The aim is not only that the learners acquire specific knowledge but also demultiplicative (e.g. consultation of reference guides, note taking), strategic (e.g. explanations skills) and dynamic skills. They stated educational robotics offers a great opportunity to collaboration. Similarly, McGoldrick and Huggard (2004) study focused on peer learning in Lego Mindstorms environments, and they concluded that the students practiced and reflected their group collaboration and peer learning in addition to the improvement on their problem solving skills. Beer, Chiel and Drushel (1999) offer Autonomous Robotics course at Case Western Reserve University. The course uses Lego robotics 
to foster a hands on, interdisciplinary, teamwork-oriented approach. As well as learning new approaches to robot control, the children engages the issues of realworld problem solving, multidisciplinary teamwork, and creative and critical thinking. Baloian, Hoeksema, Hoppe, and Milrad, (2006) used Lego Mindstorms in their Challenge-Based Learning (CBL) method which is a special form of problembased learning, in which the problems are of realistic, open-ended nature. They defined the instructors' role as coach, co-experimenter and designer. As a sum, the robotic activities like in a robotic camp provide learners cooperative environments in which group processing and peer learning could easily be achieved. In that environments, the role of the instructors are coaching.

\subsection{Coaching}

The teachers' role in a cooperative group work is different that classic learning environments. Coaching students' group work process is one of them. Dennen (2004) defined coaching as the monitoring students' activities and assisting and supporting them when it's needed. For most of the people, coach term brings to mind sports. Coaching is also commonly heard in technology and business settings. According to Jonassen (1999) a good coach motivates learners, analyzes their performances, provides feedback and advice on the performances and how to learn about how to perform, and provokes reflection on and articulation of what was learned. According to Tinzmann et al., (1990) coaching involves giving hints or cues, providing feedback, redirecting students' efforts, and helping them use a strategy. The major principle of coaching is providing the right amount of help when students need it neither too much nor too little so that students retain as much responsibility as possible for their own learning. The coach must be able to accomplish four goals:

1. Make sure that within each microworld the right sub skills are acquired, instead of ones that later have to be unlearned.

2. Design the right exercises, provide the right technology, and select the right microworlds to turn nonconstructive bugs into constructive ones.

3. Demonstrate a task the way a student did it in order to maximize the student's chances of recognizing his bugs. 
4. Explicate knowledge in terms the student can understand and execute, that is, give good instructions. (Burton, Brown, \& Fischer, 1984)

\subsection{Robotics Studies in Education}

Papert (1993) says that robots are one of the best tools to implement constructivist learning principles. Some of the studies with robotic activities resulted that robotic activities increased students' motivation toward mathematics and science courses (Robinson, 2005; Rogers \& Portsmore, 2004). They provide practice platform for science and mathematics principles (Rogers \& Portsmore, 2004), and increased students problem solving skills (Beer et al., 1999; Nourbakhsh et al., 2004; Petre \& Price, 2004; Robinson, 2005; Rogers \& Portsmore, 2004). However, some studies could not find positive effect of robotics in educational settings (Bjoerner, 2009; Fagin \& Merkle, 2003; Hussain, Lindh, \& Shukur, 2006; McNally, Goldweber, Fagin, \& Klassner, 2006).

One of the large scale studies about robotics ("Study of educational impact of the LEGO Dacta materials-INFOESCUELA-MED. Final Report.," n.d.) was conducted in Peru. The quasi-experimental, posttest-only approach was used. Fourteen schools were selected to participate in the study. The sample involved 553 students in grade 2, 566 students in grade 4, and 534 students in grade 6. Many post-test employed to assess the students' ability to use mathematical skills related to real world problems, technology knowledge, Spanish performance, eye-hand coordination, problem solving and self-esteem. After one year usage of LEGO, the results revealed that students in the experimental group had outperformed the students control group in math, technology, Spanish, and eye-hand coordination. The difference between the boys and girls were not significant.

Hussain, Lindh, and Shukur (2006) made similar large scale study to investigate the effect of one year of regular LEGO training on pupils' performance in schools in Sweden. There were 322 students, 193 at fifth grade and 129 at ninth grade in experimental group and there were 374 students, 169 at fifth grade and 205 at ninth grade. Then they looked at achievements in mathematics for fifth grade students before and after the training by using the standard two-sample t-test, they found a 
positive shift in the mean from 0.711 to 0.817 with $\mathrm{p}$-value $=0.000$ indicating better performances in mathematics for the trained group. For the problem solving, on the other hand, they have found a slight shift in the opposite direction from 0.696 to 0.649 with $p$-value $=0.023$ which is rather significant. When ninth grade students were compared they did not find any significant difference neither mathematics nor problem solving.

Fagin and Merkle (2003) used robots to teach computer science at 2000 - 2001 academic year. Their computer science course was given to 938 freshman year students in 48 sections of 15-20 students each. Nine of these sections were designated as "robotics" sections, where they provided laboratory instruction using Lego Mindstorms robots and programming environments. They found that the test scores were lower in the robotic sections than in the non-robotic section. They concluded that this result occurred because students in robotics section must run and debug their programs on robots during assigned lab times, therefore deprived of both reflective time and the rapid compile-run-debug cycle outside of class that was an important part of the learning process.

Williams, Ma, Prejean, and Ford, (2008) prepared a two week summer robotic camp to explore middle school students' physics content knowledge and scientific inquiry skills. A single group of 21 summer camp participants was pre-tested, exposed to the summer camp program, and post-tested. The result of the study revealed that the robotics summer camp had a statistically significant impact on students' gains in physics content knowledge, however, no statistically significant difference was found on scientific inquiry skills.

Robinson (2005) has interviewed with the science teachers who used Robolab (Mindstorms programming environment) in 8th grade physics courses; the teachers reported that; robotic activities increased students' motivation and attitude toward the physics and students' inquiry skills. Moreover, Petre and Price, (2004) observed and interviewed the children who attended RoboCup Junior (6 - 18 years old) and RoboFiesta (12 -14 years old). The children stated that robots had positive effect on their programming, problem solving, and team work skills also hardware and electronic knowledge had increased. 
McNally, Goldweber, Fagin, and Klassner (2006) focused on disadvantages of the robots in educational settings. They defined logistical and pedagogical disadvantages. "The primary logistical disadvantage is cost. While it is not overly expensive to outfit a lab with Mindstorms-based robots, it is too expensive to provide each Computer Science 1 (CS 1) student with their own robot. This implies that all student experimentation is limited to the robot lab's operating hours" (p.61). This disadvantage was similar to result of Fagin and Merkle's (2003) study. Unfortunately, various sensor of Mindstorms need to be re-calibrated for changing physical environments, and battery level of the robot will change turning angle and speed of the robots. Learned programming skills should be both worthwhile and useful; however learned programming skills from Mindstorms will not be reused or reinforced anywhere else in the undergraduate CS curriculum.

One of the study conducted by Barker and Ansorge (2007) focused on investigation of the effectiveness of an informal 4-H science curriculum to teach SET (Science, Engineering and Technology) concepts and validation of assessment instruments. LEGO Mindstorms kit and Robolab programming software were used at an afterschool program and 42 students aged 9 to 11 participated the study. The result of the study showed that even though there was improvement on the post-test with the experimental group, the control group scored better on some items.

Ruiz-del-Solar and Aviles (2004) developed range of robotic activities to motivate school children for pursuing studies in science and technology and university careers in science and technology, increasing their technological literacy and becoming technology-friendly adults. More than 700 children from 7th through 10th grade and 90 teachers participated in the workshops. They evaluated the workshops with questionnaires focused children's satisfaction, the level of completed work and interest in pursuing an engineering career. They reported that $92 \%$ of the participants satisfied with the workshop, $88 \%$ finished all the basic tasks during the workshop and $86 \%$ of the participants indicated they will follow an engineering or science university career in the future. They found that children's self-motivation seems to be the key element for their success during the workshop; unmotivated children do rather poorly. Moreover, the group structure also plays an important role for success 
of the workshop. Best group works occurred when previously unknown participants meet each other for the first time during the workshop to form a working team.

In the fall of 1998, the Pennsylvania Department of Education granted Bloomsburg University to support the creation of an innovative problem-solving course that would use a combination of logic, hands-on experience, and trial and error to help students identify the process behind effectively solving problems (Mauch, 2001). During summer of 1999, eight middle school teachers from many districts enrolled in a twenty hours course to learn about the LEGO Mindstorms system and how to implement it within their curricula. In the second week, forty gifted students from 6th to 8th grade attended a thirty hours camp taught by these teachers. The students were placed in a group of four and each one received a specific task such as builder, programmer etc. The teacher reported that three students would be ideal and the system should be more readily implemented in a classroom where the same students had the same robotic system each day for several weeks. Mauch (2001) concluded that this new product has shown promise, "students remain highly engaged throughout the process because they visualize their robots as a toy" (p. 212). However, cost, and classroom implementation are the primary problems. In addition, the nature of the system requires considerable time engagement for both students and teachers.

Bjoerner (2009) conducted a study with 300 Danish children aged 9-14 focused on the question of children's attitudes towards robotic technology. Half of the children participated in the robotic competition FLL (First Lego League) and the other group (from the same geographic area) did not. He concluded that there were no significant differences concerning attitudes towards robots between children who participated in the robotic competition FLL and children who did not.

\subsection{Robotics Camps}

Many universities and schools prepare technology and robotic related camp for children such as Carnegie Mellon University (Nourbakhsh et al., 2005), University of Minnesota (Cannon, Panciera, \& Papanikolopoulos, 2007; Cannon et al., 2006), 
University of North Texas (Keathly \& Akl, 2007), Lipscomb University (Nordstrom et al., 2009) etc.

However limited number of the researchers share their experiences about their how they conducted the robotic camp. Murphy and Rosenblatt (2000) presented their daily teaching syllabus and they explained the activities in the camp. Moreover, Nourbakhsh et al. (2005) offered the curriculum of their course Robotic Autonomy which is a seven week, hands on introduction to robotics design for high school students with daily plan.

In addition, these studies are not aimed to define success factors for a robotic camp; they just shared how they conducted their robotics camp and the activities. It is clear that, there is need to define success factors of a robotic instructional camp and evaluation of these factors.

\subsection{Summary and the Gaps in the Literature}

This chapter began with the philosophy of the robotic studies; constructionism and continued with the history of LEGO Mindstorms robots. One of the main purposes of using LEGO Mindstorms in educational settings is to support STEM education. Therefore, STEM education in Turkey was presented. Some robotic camp related issues such as cooperative learning, and coaching related literature were expressed. Then robotic studies in education were presented. Lastly the chapter was concluded with limited number of the studies related to robotics camp curriculum and activities. The main point is that use of robotics for STEM education is untouched area in Turkey and there is a gap on the literature about success factors of a robotic camp. Also, detailed educational robotics camp design guidelines are not available. These factors should be investigated to design better educational robotics training camps. 


\section{CHAPTER 3}

\section{METHODOLOGY}

A research design is a logical plan for getting from here to there, where here may be defined as from an initial set of questions to be answered, and there is some set of conclusions (answers) about these questions. Between "here" and "there" may be found a number of major steps, including the collection and analysis of relevant data (Yin, 2009, p.26).

"Here" of this study is the research questions described in the introduction chapter. This chapter describes the steps taken between research questions and conclusion. In this chapter, firstly, research questions will be reminded to the reader and then rationale of why multiple-case design methodology approach was chosen will be described. Later, for better understanding of the study, some related concepts "Young Inventors Build Robots and Discover Science Project", The Educational Volunteers Foundation of Turkey (TEGV) and Lego Mindstorms NXT sets will be explained. Then, implementation, data collection and data analysis phases of the study will be described. Lastly, trustworthiness of the study will be discussed.

\subsection{Research Questions}

The study was guided by the following research questions:

- What are the key design and development principles for an educational robotics training camp?

For an effective robotic camp;

- How should the instruction be structured? 
- What are the group and gender issues?

- What are the issues and strategies about cooperation and competition among learners?

- How should coaching be provided? What are the successful coaching strategies and issues?

- What are the technical issues and strategies for a successful training camp?

\subsection{Rationale for the Multiple-case Design}

After deciding the problem, the researcher should select an approach to investigate the problem. According to match between problem and approach, personal experiences and audience, the researcher ought to choose one of the approaches of qualitative, quantitative or mixed method. Creswell (2002) stated that a phenomenon or concept deserves a qualitative approach when it needs to be understood because little research has been done on it. When the researcher does not know the important variables to examine, qualitative research is useful because it is explanatory. Accordingly, the goal of this research is to understand the success factors of an effective educational robotic camp. The researcher picked qualitative approach to investigate the problem, because of necessity of exploratory design and lack of literature about educational robotic camps.

Van Maanen (1979, p. 520) defined qualitative research as "an umbrella term covering an array of interpretive techniques which seek to describe, decode, translate, and otherwise come to terms with the meaning, not the frequency, of certain more or less naturally occurring phenomena in the social world". Denzin and Lincoln (2005) identify six qualitative research types; case study, ethnography, grounded theory, life and narrative approaches, participatory research and clinical research. Merriam (2009) also identified six qualitative research types which are basic qualitative research, phenomenology, grounded theory, ethnography, narrative analysis, and critical qualitative research. After, deciding to use qualitative approach, the researcher should decide which type of qualitative research is appropriate to investigate the research problem. When each qualitative research types and their characteristics considered, case study was chosen as the most appropriate qualitative research type for this study due to the following reasons. 
Yin (2009) defines case study as "an empirical inquiry that investigates a contemporary phenomenon within its real-life context, especially when the boundaries between phenomenon and context are not clearly evident" (p. 18). He also explains four different applications (to explain, describe, illustrate and enlighten) of the case study. The most important one is that case study can be used to explain the assumed causal links in real-life interventions which are too complex for the survey or experimental. He stated that the case study has a distinct advantage in some situation in which "how" and "why" questions are being asked, contemporary set of events and little or no control of investigator. The purpose of this study is to determine the factors that affect success of a robotic training camp. Without knowing the success factor for a robotic training camp, it is impossible to conduct a survey or an experimental study. Therefore, robotic training camp(s) should be understood with case study approach. Thus, each success factors could be defined and described; illustrated how each factor affects a robotic camp and enlightened how these factors should be implemented for a successful robotic training camp.

Yin (2009) advises that if researchers have the choice (and resources), multiple-case design should be preferred. Even if at two-case case study, researchers have chances of doing a good case study will be better than using a single-case design. A common example of multiple-case design is a study of school innovation such as use of new curricula, rearranged school schedules or a new educational technology. Because of all these characteristics and the match between the researcher's intention to investigate the problem and Yin's (2009) explanations and suggestions; multiple-case design was used to investigate the research problem of this study.

\subsection{Study Related Concepts and Issues}

\subsubsection{Young inventors build robots and discover science project}

The Scientific and Technological Research Council of Turkey (TÜBİTAK) supports "Science and Society Projects". With these projects, the aim of TÜBİTAK is to transfer knowledge to society in an understandable way. While doing this, the knowledge should be visualized as possible as it could be and should be supported with interactive applications. "Young Inventors Build Robots and Discover Science 
Project" was designed and proposed to TÜBİTAK for this purpose. The scope of the project was offering 10 days educational robotic camp for children. In the camp, children design their robots with LEGO Mindstorms NXT robotic sets and while designing their robots they realize how they could use mathematics and science subjects in real life. The project was managed by the researchers from three different universities and supported by TÜBITAK.

The first camp was implemented between 25th January and 5th February of 2010 during the semester holiday. After the successful implementation of the first camp, the managers decided to organize the second one. The second camp was implemented between 12th and 23th July of 2010. Both camps were implemented at The Educational Volunteers Foundation of Turkey (Türkiye Eğitim Gönüllüleri Vakf1, TEGV) Semahat - Dr. Nüsret Arsel Education Park.

\subsubsection{The educational volunteers foundation of Turkey (TEGV):}

The Educational Volunteers Foundation of Turkey (Türkiye Eğitim Gönüllüleri Vakf1, TEGV) is a non-profit civil society organization. TEGV was founded by Suna Kıraç to support eight year basic education (elementary education) on 23 January 1995. The foundation provides a comprehensive program of activities organized within five learning areas; a) personal development b) social development c) language, art, communication d) history, geography, culture and e) mathematics, science and technology

The aim of the foundation is to empower 7-16 years-old primary and secondary school students to discover themselves, develop usable skills, broaden social commitment and gain a global perspective. For this purpose the foundation consists of three different types of facilities; education parks, learning centers and firefly mobile units.

Today, donors of the foundation are more than 200 thousand and it is the first time that foundation has donors at this count in Turkey. There are more than 10 thousand volunteers have been working for the foundation. The foundation gave non-formal education for more than 600 thousand young people (Kirac, 2006). 
The foundation is aware of importance of the technology and emphasizes technology related activities. All education parks of the foundation have computer laboratories for supporting technology literate generations. "Knowledge is my job" (Bilgi Benim İşim, BBİ) project reflects their concern about technology. Aim of the project is giving technology and computer literacy to 217.000 primary and secondary school students in three years. Nearly, all education parks of the foundation attend FLL robotic competition every year to give the children a new vision.

\subsubsection{Utilized materials}

The LEGO Mindstorms NXT Education robot kits were used for this study. The LEGO Mindstorms NXT kits consist of a central block (the NXT), a set of sensors (touch, ultra sonic, sound and light), 3 servomotors, and a wide selection of LEGO building pieces (including gears, wheels and structural pieces). The NXT contains a 32-bit ARM7 microcontroller, 3 output ports (for motors), 4 input ports (for sensors), a USB port, a loudspeaker, 4 buttons, a display and Bluetooth wireless communication. Internal memory is used to store programs, sound files, graphics files and text files. Sensors can be mounted in a myriad of different configurations, with up to four connected to the NXT at a time. The NXT supports up to three motors, connected in various fashions, and powered by three dedicated motor ports. Bluetooth capability allows communication between NXT's and other Bluetoothenabled devices.

The LEGO Mindstorms NXT kit provides a powerful; easy-to-use programming environment called NXT-G (Figure 3.1). The software enables users to program their NXT robotic inventions and upload programs to the NXT brick via USB or Bluetooth connectivity. Drag-and-drop programming approach is used in NXT-G. That is user drag and place predefined programming blocks on the screen to create a program. The users do not need to write any code. Each block performs a unique function such as moving the motors, displaying a message, detecting a sound, or measuring a distance (Perdue, 2008). It makes developing programs with the LEGO Mindstorms NXT software fun and simple (Ranganathan, Schultz, \& Mardani, 2008) 


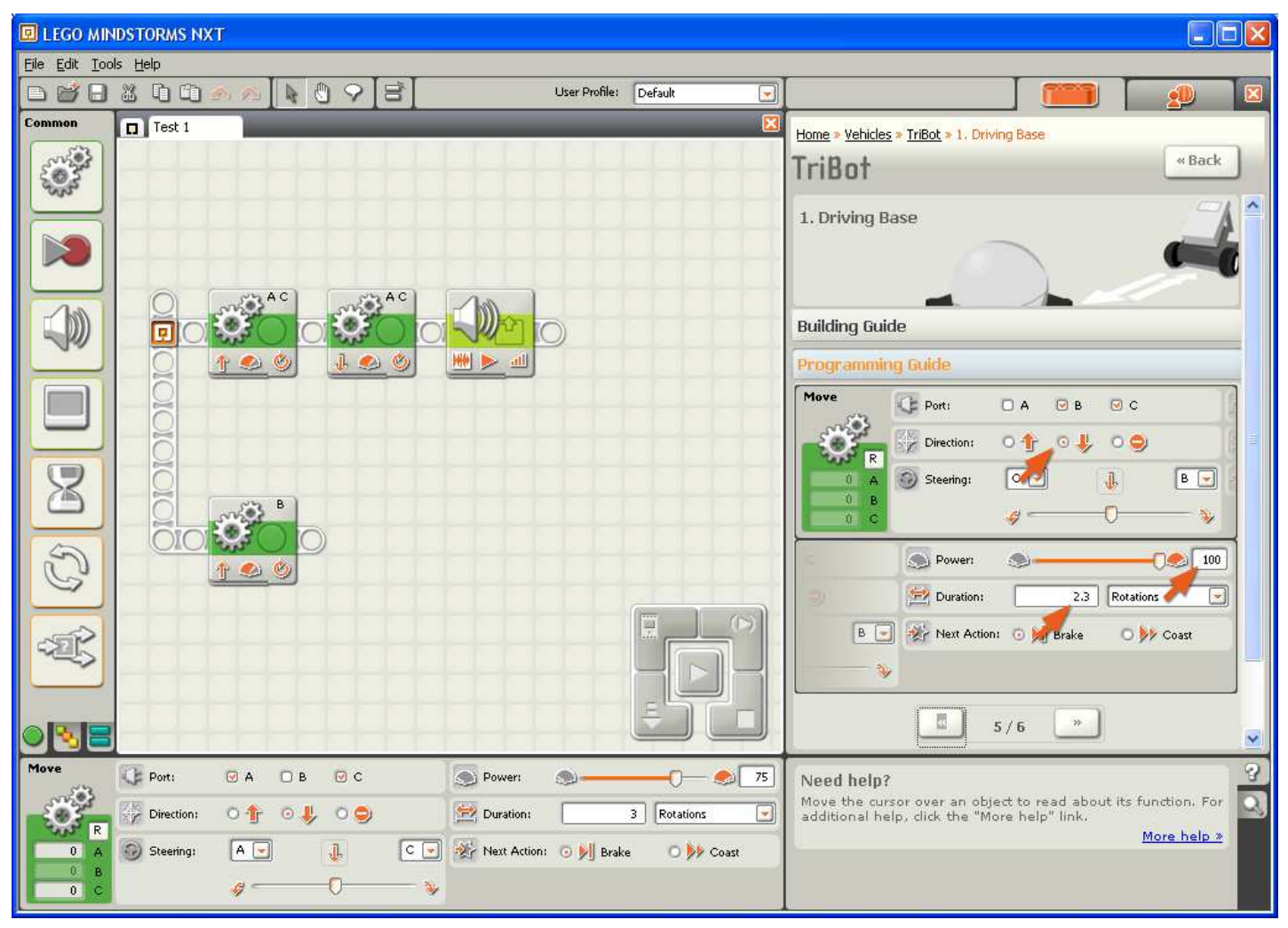

Figure 3.1 LEGO Mindstorms NXT programming environments NXT-G

\subsection{Implementation}

Actual data for the study was collected from two ten-days-long robotic camps.

However, the schedule of the study started long before the first camp. Table 3.1 summarizes the schedule of the study. 
Table 3.1

Schedule of the study

\begin{tabular}{cll}
\hline Activities & \multicolumn{1}{c}{ Date } & \multicolumn{1}{c}{ Explanations } \\
\hline The first pilot study & $\begin{array}{l}\text { Summer semester } \\
\text { of } 2009\end{array}$ & $\begin{array}{l}\text { Pilot study conducted with 12 children. } \\
\text { 4 week long with 4 hours meetings in a } \\
\text { week. }\end{array}$
\end{tabular}

The second pilot study

Fall semester of 2009

18 January 2010

The first camp instructors meeting
Pilot study conducted with 16 children and an observer. 8 week long with 2 hours meetings in a week.

Two hours long one meeting with instructors and project manager for evaluation of camp curriculum and activity sheets.

Two hours long

Practice of the camp

19 January 2010

Practice of the camp with 10 children and 5 instructors between 13:50 to 16:00 at camp area.

The implementation of the first camp with 28 children studying $6^{\text {th }}$ grade.

to

5 February 2010

The second camp 16 June 2010 instructors meetings

07 July 2010

One and a half hours long two meetings before the second camp to discuss curriculum changes with instructors and project manager.

The implementation of the second camp with 22 children at $6^{\text {th }}, 7^{\text {th }}$ and $8^{\text {th }}$ grades.

23 July 2010 


\subsubsection{Pilot Studies}

As stated in the introduction chapter, the researcher is a volunteer educator at The Educational Volunteers Foundation of Turkey (Türkiye Eğitim Gönüllüleri Vakfı, TEGV) Semahat - Dr. Nüsret Arsel Education Park. He had been the coach of the team attending to First Lego League (FLL) robotics competition for two years.

The researcher and his colleagues had developed a four week robotics activities at summer semester of 2009. In that summer semester, students attended to robotic activities for four hours a week. In the first week, brief information about the components of the robot sets and programming software was introduced to the students. The students constructed their robots with the help of manual. At the end of the first week, students learned how to build and program robots. In the second week, the students used sensors with their robots such as ultrasonic sensor to avoid obstacles and light to follow a predefined path. For the following two weeks, students created their own robot. Students created scenario of the activity, appropriate robot design and they programmed their robots.

According to the feedbacks of the first pilot study, some activities were redesigned and second pilot study was designed. In the fall semester of 2009, the second pilot study was conducted with improved activities. There were some differences at implementation of summer semester and fall semester. In fall semester, the students attended the robotic activities during weekends and two hours at a week, the summer semester they had attended four hours a week. However, unlike the four week long summer semester, the fall semester was eight week long. Therefore, total class hours for two semesters were equal.

At the end of these two pilot studies, the researcher has got used to target audience. The researcher tried to understand how they interact with robots, how they behave in non-formal educational settings, and what kind of problems can occur in similar settings. Beside the audience, the researchers gained experiences about NXT Mindstorms sets and programming environments. Moreover, one colleague attended to the second pilot study as an observer. These observation notes were used to design instruction and interview schedule for the camps. 


\subsubsection{The first camp instructors meeting}

Just before the meeting of the first camp, the researcher and the instructors joined the "Young Inventors Build Robots and Discover Science Project". Before that, the researcher has been conducting pilot studies and the instructors also had prepared learning materials for LEGO Mindstorms NXT sets and the project had already approved by TÜBİTAK. The camp curriculum was evaluated at the meeting, mostly instructional aspects and science and mathematics concepts reviewed. It was decided to prepare activity sheets for science and mathematics concepts and each activity sheet assigned to an instructor. Moreover, robotic completions and tournaments such as programming robots to move exactly two meters with three different tires decided and suggested to add related activity sheets. Later, communication was made via email.

\subsubsection{Practice of the camp}

After the camp program and activities prepared, robotic activities from second day of the camp curriculum was practiced with five instructors and 10 children at the hall the place where the camp will be conducted. Aims of this practice were to evaluate the appropriateness of the activities to target audience and to measure their reaction. After this practice and little revision, camp program has reached its final format.

\subsubsection{Case 1: the first camp}

The first camp was implemented at The Educational Volunteers Foundation of Turkey (TEGV) Semahat - Dr. Nüsret Arsel Education Park between $25^{\text {th }}$ January and $5^{\text {th }}$ February of 2010. Manager and staff of the park gave support to the camp; they took care of from application to the camp to the children nutrition.

Thirty sixth grade students attended to the camp. During the camp the children had chance to learn programming of the robots with NXT-G programming software and work on science and mathematics activities with the LEGO Mindstorms NXT sets. Camp curriculum and activities were prepared in a constructionist approach that is main purpose of the camp was to create an environment where the children could learn by making. 
First six days of the camp, the children learnt robotic concepts and worked on science and mathematics activities with robots. Following three days, they built robotic projects to propose a solution to some problems in their life. They presented their projects to their families on the last day of the camp (more details about the camp and dairy of the camp can be seen in the next chapter).

\subsubsection{The second camp instructors meeting}

Before the second camp, two instructor meetings were conducted to evaluate the first camp results and to discuss required curriculum change. The meetings lasted around one and a half hours at 16 June and 07 July 2010. The decisions were taken during these meetings: (a) number of attended children must be at most 24; (b) an instructor would be assigned to each group; (c) competition should be keep minimum; (d) learning station approach would be implemented; and (e) first three days of the camp the children would learn only programming.

\subsubsection{Case 2: the second camp}

Like the first camp, the second camp was also implemented at The Educational Volunteers Foundation of Turkey (TEGV) Semahat - Dr. Nüsret Arsel Education Park between $12^{\text {th }}$ and $23^{\text {th }}$ July 2010.

Twenty two $6^{\text {th }}$ to $8^{\text {th }}$ grade students attended to the camp. Unlike the first camp, the children have taught robots and programming during the first three days of the camp. During the next three days of the camp, each group joined six different half day long learning stations. Like the first camp, the children created robotic projects and presented their projects to their families in the following days of the camp (more details about the camp and diary of the camp can be seen at next chapter).

\subsection{Data Collection Procedure}

According to Yin (2009), a case study research is not limited to one single source of data; a good case study benefits from having multiple sources of evidence. He defined six common sources of evidence which are documents, archival records, interviews, direct observation, participant observation, and physical artifacts. 
Interviews, observations, field notes, and evaluation forms were the data collection methods for this study.

After related literature review and preparation of the data collection tools, the researcher took the required permissions for conducting research involving human subjects from Ethical Committee of METU (See Appendix C).

First day of the camp, the participants were asked for their parent permission to attend the study. For this purpose, a consent form which summarizes the camp, ethical issues and asks for permission to their children to attend the study was delivered. All parents accepted and signed the consent forms (See Appendix D). Table 3.2 summarizes data collection tools and procedure. 
Table 3.2

Data collection procedure

\begin{tabular}{llll}
\hline Methodology & Sources & Procedure & When \\
\hline Interview & Participants & $\begin{array}{l}\text { Semi-structured interviews were recorded } \\
\text { with a digital recorder. }\end{array}$ & $\begin{array}{l}\text { Last three days of the both } \\
\text { camps. }\end{array}$ \\
Focus group interview & Other instructors & $\begin{array}{l}\text { Semi-structured interview was recorded } \\
\text { with a digital recorder. }\end{array}$ & Just after the second camp. \\
& & (23.07.2010)
\end{tabular}




\subsubsection{Interviews}

Interview is "a process in which a researcher and participant engage in a conversation focused on questions related to a research study" (DeMarrais, 2004, p. 55). A researcher conducts interview because it is the only way to understand someone's feelings, thoughts, and intentions. Interview allows a researcher to enter other person's perspective (Patton, 1990). The primary data collection method was one-on-one semi structured interviews with the children attended to camps.

Interview schedule for this study was prepared by the researcher during a Qualitative Research Course. With the guidance of the course instructor, interview questions were prepared to address research questions. Interview schedule was piloted with some of the students who attended to pilot study. Because of short interview time and the feedback gained from the interviewees, some new questions were added to interview schedule. The final interview schedule includes 9 questions with sub questions (See Appendix A). Example interview questions were given below:

1. Can you evaluate the process you worked with robots?

a. Was it fun?

b. How do you feel about the camp?

c. What are the benefits for you?

i. Can you give examples?

d. What have you learned in this process?

i. Can you give examples?

e. Have you had got into stuck?

i. Can you give examples?

2. Have you had problems with your group mates? What kind of problems were they?

Probe: Not taking responsibility

Probe: Personal problems

a. How did you solve these problems?

b. What should the instructors do? 
All final interviews were conducted by the same researcher in order to ensure consistency of data collection procedure and to obtain maximum reliability on the data. Interviews were conducted during the last three days of the camp in a private room. Before each interview, the interviewee was informed about the interview, confidentiality and asked permission for recording of the interview. Except one participant, all participants accepted using a recorder. Then, the researcher started to interview according to interview schedule, if it was needed, further explanation and clarification was done during interviews. Each interview lasted from ten to twenty minutes.

In addition to the interviews with the children, the researcher and the instructors (except one) conducted a group interview just after the second camp. Purposes of the interview were mostly evaluating the instructional aspect of the camp, making selfcriticism, and discussing each camp's positive and negative aspects.

\subsubsection{Observation}

Observation, like interview, is another primary source of data in qualitative research. Observation has two characteristics which differentiate it from interview. Firstly, observation occurs in the settings where the phenomenon of interest naturally occurs. Secondly, observer has firsthand experience with phenomenon and informant (Creswell, 2007; Merriam, 2009). Participant-observation is a special mode of the observation in which the observer is not passive. Instead, the observer takes a variety of roles within a case study and may participate in the events being studied (Yin, 2009).

The researcher worked as an instructor at both camps. Therefore, he was a part of the case and had a chance to experience the phenomenon at firsthand. The researcher observed the situation as a participant-observer. The main concern of the observation was identifying the social issues, effectiveness of the robotic activities and the positive or negative experiences they have lived. The researcher took notes and summarized events when he needed and every evening, he made a fair copy of these observation notes. 
Moreover, a video recorder was used to record the social atmosphere, to later evaluate the events in the first camp. Before the second camp, one of the advisors advised to use two video recorders. Therefore, two recorders were used in the second camp, one recorder used to record the whole hall and one recorder used to record a randomly selected group. Thus, between and within group social interactions were recorded to evaluate in the second camp.

\subsubsection{Camp evaluation forms}

During the camps, participants were asked to evaluate the camp every two or three days evening with an evaluation form (See Appendix B). Aim of the evaluation form was twofold, first, participants could have chance to express themselves without hesitating from group mates or instructors. Second, because the researcher conducted interviews with the participants at the last days of the camp, it could be too late to discuss some daily events. Evaluation form was created by the researcher and it consists of four following open ended questions:

- What have you learned in the camp today?

- What are the positive or negative experiences with your group-mates?

- What are the positive or negative experiences with the instructors?

- Could you evaluate today's activities (deficiencies, suggestions, positive or negative experiences that affected you)

\subsection{Data Analysis Procedure}

"Analyzing the data in a qualitative study essentially involves analyzing and synthesizing the information the researcher obtains from various sources into a coherent description of what he or she has observed or otherwise discovered" (Fraenkel \& Wallen, 2003, p. 435). To start the data analysis phase, the researcher transcribed all interview records and observation notes. To give coherent description, the date should be coded. Coding is analytic process through which concepts are identified and their properties and dimensions are discovered in data. During the coding procedure data are broken down in to discrete parts, closely examined and compared for similarities and differences. Events, happenings objects and actions/interactions that are found to be conceptually similar in nature or related in 
meaning are grouped under more abstract concepts termed "categories" (Strauss \& Corbin, 1998). In this study, attribute coding, structural coding, descriptive coding and pattern coding techniques were used. Attribute coding is coding a record of data known about the case, such as participants' characteristics or demographics. This data is recorded separately from the text generated by that case (Bazeley, 2007; Saldana, 2009). Structural coding is another fist cycle coding, and used to collect similar segment of data that related to a specific research question. Similarly, coded segments of data collected for more detailed coding and analysis (Saldana, 2009). Descriptive coding is summarizing a class of phenomena with a segment of text most often as a noun. Description is the basics for qualitative analysis and its primary goal is to assist the reader to show what you saw (Miles \& Huberman, 1994; Saldana, 2009). Lastly, pattern coding is a second cycle coding. Miles and Huberman (1994) defined pattern code as "explanatory or inferential codes, ones that identify an emergent theme, configuration, or explanation. They pull together a lot of material into more meaningful and parsimonious units of analysis. They are a sort of metacode... Pattern coding is a way of grouping those summaries into a smaller number of sets, themes, or constructs" (p. 69).

NVivo 8 a Computer Assisted Qualitative Data Analysis Software (CAQDAS) was used while analyzing the data. As Bogdan and Biklen (2007) stated, computer program only helps to organize or categorized to data, and it does not analyze data for researchers. However, there are some advantages of using a CAQDAS. Firstly, these programs offer an organized filing system therefore data can be retrieved according to categories or codes easily and this gives the researcher more time to think about the meaning of the data. Secondly, these programs encourage a close examination of the data. Thirdly, the concept map feature of these programs helps the researchers to visualize relationships among data (Merriam, 2009).

Because of the nature of Nvivo, first the list of the children who attended to the camp were imported as individual cases and their attributes (gender, grade and schools) were given. Later, interviews and evaluation forms also imported to the program and the connection between a case and interview and evaluation forms of that case were done. This data preparation process was done similar way for the second camp's 
data. The researcher created different Nvivo files for each camp's interviews and evaluation forms, each camp's video recordings and instructors' interviews.

Especially interviews and evaluation forms file, firstly the data were coded as free nodes. Later, these free nodes organized by using Nvivo tree nodes feature. Therefore, each camp's data were coded and organized and analysis of the each case is completed.

In a multiple-case study, there are two stages of analysis: within-case analysis and cross-case analysis. For the within-case analysis each case treated as independent research studies. When the analysis of the each case is completed cross-case analysis begins. The researcher attempts to find general explanation that fits the individual cases (Miles \& Huberman, 1994; Yin, 2009).

For the cross-case analysis the researcher did not used any software, because the two camps' codebook were compared, their similarities and differences easily perceived.

\subsection{Trustworthiness of the Study}

In quantitative studies, validity and reliability are two important issues, because the inferences drawn should base on valid and reliable data. Validity is defined as “...referring to the appropriateness, correctness, meaningfulness, and usefulness of the specific inferences researchers make based on the data they collect (Fraenkel \& Wallen, 2003, p. 158). Reliability, “...refers to the consistency of the scores obtained-how consistent they are for each individual from one administration of an instrument to another and from one set of items to another" (Fraenkel \& Wallen, 2003, p. 158).

Validity and reliability concepts should be thought differently in qualitative research because these terms are not suitable to nature of qualitative research. Lincoln and Guba (1985) substituted reliability and validity with the parallel concept of "trustworthiness," containing four aspects: credibility, transferability, dependability, and confirmability. Therefore, in qualitative research we can mention credibility instead of internal validity, transferability instead of external validity, dependability 
instead of reliability and confirmability instead of objectivity (Yildirim \& Simsek, 2006).

Credibility (internal validity) "...deals with the question of how research findings match reality" (Merriam, 2009, p. 213). Additionally, Merriam (2009) suggests strategies to increase the credibility of the findings; triangulation (methods, source of data, investigator and theory), member check, adequate engagement in data collection and peer examination. Lincoln and Guba (1985) also suggest prolonged engagement, persistent observant, triangulation, peer debriefing and member check (Guba, 1981) for credibility of a study.

The researcher tried to ensure credibility through firstly prolonged engagement. The researcher was a volunteer instructor at the education park for two years. Moreover, during the pilot studies the research work with target group students in a camp similar environment and activities. Secondly, the researcher persistently observed the situation (every day of the camps). The data were collected with multiple methods (interview, observation, camp evaluation forms and content analysis) and from different sources (children and instructors). Because of the nature of dissertation writing process, the process and findings were read and reviewed by who acted as the peer reviewer.

The second criteria to establish trustworthiness in a qualitative study is transferability (external validity). Transferability is "concerned with the extent to which the findings of one study can be applied to other situations" (Merriam, 2009, p. 223). Thick description and maximum variation in the sampling are the two strategies to enhance transferability of the study (Merriam, 2009; Simsek \& Yildirim, 2008).

To enhance transferability of the study, both camps were described in the next chapter, not only characteristics, differences or similarities but also each day of both camps were thickly described.

The third criteria to establish trustworthiness is dependability (reliability). In quantitative studies reliability is concerned with if the study replicated could it yield the same result (Merriam, 2009). This approach in a qualitative study is problematic because human behavior's is never static, the more important question in qualitative 
studies is "...whether the process of the study is consistent, reasonably stable over time and across researchers and methods" (Miles \& Huberman, 1994, p. 278). Audit trial (Lincoln \& Guba, 1985) and intercoder agreements (Creswell, 2007) two strategy to enhance dependability of a study. "An audit trail in a qualitative study describes in detail how data were collected, how categories were derived, and how decisions were made throughout the inquiry" (Merriam, 2009, p. 223). Comparison of the code segments which are coded by different coder to establish the reliability of the data analysis process is called intercoder agreements (Creswell, 2007).

The researcher tried to explain the research design of the study that is how data were collected, how categories were derived in a detail to help other researchers to repeat the study. Moreover, randomly selected five interviews and coding table were sent to a graduate student, he was using Nvivo for his study, via e-mail. He coded these five interviews in Nvivo software. Then intercoder reliability was calculated by using “coding comparison query” feature of Nvivo software. Minimum 86.82\% agreement was achieved. Complete coding comparison table can be seen at Appendix L.

The last criteria to establish trustworthiness in a qualitative study is confirmability (objectivity). In a scientific study, it expected that the results of the study should be objective, should not include the researcher's biases. However pure objectivity is impossible in qualitative study (Simsek \& Yildirim, 2008). Therefore, the naturalistic researcher looks for confirmability which "are established through an auditing of the research process" (Creswell, 2007 p. 204) and triangulation (E. Guba, 1981).

The researcher tried to ensure confirmability through triangulation and detailed description on the methodology of the study. Triangulation achieved by collecting date with multiple methods (interview, observation, evaluation forms and content analysis) and from different sources (children and instructors). Data from interviews with children and instructors, observation (video recording and the researcher's participant observation), camp evaluation forms (Appendix B) and analysis of the related studies compared to know how valid the emerged categories were. 


\subsection{The Researcher}

\subsubsection{Role of the researcher}

In qualitative research, role of the researcher is different than a quantitative study. In quantitative study the role of the researcher is to be as objective as possible in order to make ultimate decisions. However, the researcher is a natural part of the data collection procedures in qualitative research (Simsek \& Yildirim, 2008). It is impossible to achieve pure objectivity (Patton, 1990). Therefore, the researcher should clearly define his role and his biases in the study.

In this study, the researcher is a volunteer of The Educational Volunteers Foundation of Turkey (TEGV) nearly for three years. Last two years, the researcher prepared the students for the FIRST Lego League (FLL) competition, which is a robotic competition around the world, on behalf of the TEGV Ankara Etimesgut Education Park. Therefore, the researcher has experience on Lego Mindstorms robotic kits and robotic activity program was designed by the researcher and his colleagues.

During the both camps, the researcher worked as an instructor. He spent all time with the children from 9:30 am to 16:30 pm. The researcher sometimes explained the subject to all students by using a video projector, sometimes he worked with a group to solve a problem as a guide, they played games together during breaks and they had lunch together every day of the camps. Because of the tradition in TEGV, all instructors are called as "brother" or "sister" by children. Therefore, the relations between the researcher and the children were much richer than an ordinary instructor-student relation.

\subsubsection{The Researcher's Biases}

Literature about "robots in education" is not deep enough, it is reported that there are positive and negative sides of using robots in education. More studies are needed to clearly understand the effects of robots in education. The researcher thought that, robots are another new media in media - method debate. He expects that the future of robots in education could be similar to radio or television's place in education. In history of instructional technology it was written that "tomorrow they will be as 
common as the book and powerful in their effect on learning and teaching" (Morgan, 1932, p. ix cited in Reiser, 2001) for radio, films and television. However over the next 20 years radio had very little impact on instructional practices (Cuban, 1986, cited in Reiser, 2001).

On the other side, the researcher worked with the children while playing with Lego Mindstorms NXT sets. He observed what Papert (1993) mean saying "object-tothink-with". Robot sets to give chance to the children to apply what they have learned in science courses and their problem solving ability while playing with them.

The researcher thinks that if we want to use robot sets somehow in education, we should investigate educational potential, media attributes and other educational aspects. We should be aware of both positive and negative effects of using robots in education before investing huge amount of money, time and labor. 


\section{CHAPTER 4}

\section{FINDINGS OF THE STUDY}

The findings of the study will be presented in this chapter. This chapter consists of three parts. One of the special features of the case study is descriptive means that the end product of the case study should be rich and thick description of the phenomenon (Merriam, 2009). For this purpose, the first camp will be introduced with participants, instructors, place and characteristics. Then diary of the first camp will be presented. Secondly, the second camp will be presented in the same way. Thirdly, the findings from both camps will be presented accordingly research questions. After presented each emerged categories, the researcher will propose robotics camp design principles for that category by considering results of the interviews, camp evaluation forms, observations and his own experiences.

\subsection{Part 1: The First Camp}

As stated in the previous chapter, the first camp was implemented between $25^{\text {th }}$ January and $5^{\text {th }}$ February of 2010, during semester holiday at The Educational Volunteers Foundation of Turkey (Türk Eğitim Gönüllüleri Vakfı, TEGV) Semahat Dr. Nüsret Arsel Education Park. The camp was organized with the support of The Scientific and Technological Research Council of Turkey (TÜBITTAK). Name of the project was "Young Inventors Build Robots and Discover Science". Three instructors from different universities of Turkey involved as directors, and two graduate and four undergraduate students participated as instructors in the project. Moreover, TEGV staff at Semahat- Dr. Nüsret Arsel Education Park supported the project. They organized the children who wanted to attend the camp, provided the place and took care of the nutrition of the children during the camp. 


\subsubsection{Participants}

"Young inventors creating robots and discovering science" robotic-science camp was announced at its website: http://robotcampi.atilim.edu.tr. Moreover, activities manager of TEGV Semahat - Dr. Nüsret Arsel Education Park informed their students who already attend the activities at TEGV and their parents about the camp. The interested students accepted to camp by filling a registration form.

The camp was conducted at Etimesgut, Ankara which is the smallest district of Ankara in area but $6^{\text {th }}$ in population (TUIK, 2010). Thirty children at $6^{\text {th }}$ grade have attended to the first camp but the interviews were conducted with nineteen boys and nine girls (Table 4.1). The researcher had intended to interview with all the participants but one of them did not let the researcher to use sound recorder and one of them did not attended to the camp on interview day.

All participants was selected from the $6^{\text {th }}$ grade students because, the camp curriculum was designed for $6^{\text {th }}$ grade students. While designing camp curriculum, $6^{\text {th }}, 7^{\text {th }}$, and $8^{\text {th }}$ grades science and mathematics curricula were investigated for suitable subjects for robotics activities. The subjects were chosen from $6^{\text {th }}$ grade curriculum, therefore it is decided that participants should be $6^{\text {th }}$ grade.

Table 4.1

Gender and grades of the first camp's participants

\begin{tabular}{lcc}
\hline Grade & Boys & Girls \\
\hline $6^{\text {th }}$ & 19 & 9 \\
\hline
\end{tabular}

Most of the children were from surrounding schools. Some studies in education classified Etimesgut as low socio-economic context (Ozbay, 2003), some studies classified as middle socio-economic context (Ozbay, Buyukikiz \& Uyar, 2011). Socio-economic status (SES) is a characteristic for a family and identified by education level, family income, parents' occupation and ownership (Kalaycıoğlu, Çelen \& Türkyılmaz, 2010). There could be the families with different SES level in 
any district; therefore it can be mentioned distribution of the SES levels for a district. In this study, the participants were not selected by random selection; therefore, SES level of the participants' families could not be resemble to the district's statistics. Thus, each participant and their characteristics are given in Table 4.2. A nick name has been given to each child according to camp number and interview order. 
Table 4.2

Participants of the first camp

\begin{tabular}{|c|c|c|c|c|c|c|c|}
\hline Nick name & Gender & Father's job & Mother's job & \# of sibling & Grade & School & $\begin{array}{c}\text { Any Lego toy } \\
\text { experience }\end{array}$ \\
\hline Kid.I.01 & Boy & Tradesman & Housewife & 4 & $6^{\text {th }}$ & Şeyh Şamil İO - Public & No \\
\hline Kid.I.02 & Girl & Worker & Housewife & 3 & $6^{\text {th }}$ & Şeyh Şamil İO - Public & Yes \\
\hline Kid.I.03 & Girl & Soldier & Housewife & 2 & $6^{\text {th }}$ & Şeyh Şamil İO - Public & Yes \\
\hline Kid.I.04 & Boy & Tradesman & Worker & 3 & $6^{\text {th }}$ & Şeyh Şamil İO - Public & No \\
\hline Kid.I.05 & Boy & Retired & Housewife & 4 & $6^{\text {th }}$ & Şeyh Şamil İO - Public & Yes \\
\hline Kid.I.06 & Boy & Tradesman & Housewife & 3 & $6^{\text {th }}$ & Şeyh Şamil İO - Public & Yes \\
\hline Kid.I.07 & Girl & Tradesman & Housewife & 2 & $6^{\text {th }}$ & Şeyh Şamil İO - Public & No \\
\hline Kid.I.08 & Boy & Tradesman & Housewife & 3 & $6^{\text {th }}$ & Şeyh Şamil İO - Public & No \\
\hline Kid.I.09 & Boy & Artist & Housewife & 3 & $6^{\text {th }}$ & Şeyh Şamil İO - Public & Yes \\
\hline Kid.I.11 & Boy & Not Working & Academician & 0 & $6^{\text {th }}$ & Teyfik Fikret İO - Private & Yes \\
\hline Kid.I.12 & Boy & Doctor & Officer & 0 & $6^{\text {th }}$ & Teyfik Fikret İO - Private & Yes \\
\hline Kid.I.13 & Girl & Worker & Worker & 2 & $6^{\text {th }}$ & Semiha İsen İO - Public & Yes \\
\hline Kid.I.14 & Girl & Tradesman & Nurse & 2 & $6^{\text {th }}$ & Semiha İsen İO - Public & Yes \\
\hline
\end{tabular}


Table 4.2 (continued)

\begin{tabular}{|c|c|c|c|c|c|c|c|}
\hline Kid.I.15 & Boy & Worker & Housewife & 2 & $6^{\text {th }}$ & Ali Suavi İO - Public & No \\
\hline Kid.I.16 & Boy & Officer & Housewife & 3 & $6^{\text {th }}$ & Ali Suavi İO - Public & Yes \\
\hline Kid.I.17 & Boy & Not Working & Worker & 2 & $6^{\text {th }}$ & Ali Suavi İO - Public & Yes \\
\hline Kid.I.18 & Boy & Officer & Housewife & 0 & $6^{\text {th }}$ & Koç İO - Public & Yes \\
\hline Kid.I.19 & Boy & Tradesman & Housewife & 3 & $6^{\text {th }}$ & Koç İO - Public & Yes \\
\hline Kid.I.20 & Boy & Worker & Housewife & 4 & $6^{\text {th }}$ & Koç İO - Public & Yes \\
\hline Kid.I.21 & Girl & Tradesman & Housewife & 4 & $6^{\text {th }}$ & Koç İO - Public & No \\
\hline Kid.I.22 & Boy & Officer & Housewife & 2 & $6^{\text {th }}$ & Koç İO - Public & Yes \\
\hline Kid.I.23 & Girl & Tradesman & Housewife & 2 & $6^{\text {th }}$ & Koç İO - Public & Yes \\
\hline Kid.I.24 & Boy & Officer & Officer & 2 & $6^{\text {th }}$ & Koç İO - Public & Yes \\
\hline Kid.I.25 & Girl & Tradesman & Housewife & 2 & $6^{\text {th }}$ & Koç İO - Public & Yes \\
\hline Kid.I.27 & Boy & Worker & Housewife & 0 & $6^{\text {th }}$ & Koç İO - Public & Yes \\
\hline Kid.I.28 & Boy & Officer & Housewife & 2 & $6^{\text {th }}$ & Koç İO - Public & Yes \\
\hline Kid.I.29 & Girl & Officer & Housewife & 2 & $6^{\text {th }}$ & Koç İO - Public & Yes \\
\hline Kid.I.30 & Boy & Officer & Housewife & 2 & $6^{\text {th }}$ & Koç İO - Public & Yes \\
\hline
\end{tabular}




\subsubsection{Instructors}

In addition to the researcher, five instructors were attended to the first camp (Table 4.3). One of them (Instructor 5) was a PhD. student and he has experience with robotics, because he was a coach of a FLL team and he was also conducting studies with robotics. Four of the instructors were at final year of the university and they had already prepared a project which was applications of Lego Mindstorms NXT in educational settings. However, these four instructors could not attend the whole camp.

Table 4.3

Gender and grades of the first camp's participants

\begin{tabular}{lll}
\hline Nickname & Gender & Experience \\
\hline The researcher & Male & FLL and robotics activities at TEGV \\
Instructor 1 & Female & Project robotics in education \\
Instructor 2 & Female & Project robotics in education \\
Instructor 3 & Female & Project robotics in education \\
Instructor 4 & Female & Project robotics in education \\
Instructor 5 & Male & FLL and robotics studies \\
\hline
\end{tabular}

\subsubsection{Place}

The camp was implemented at the biggest hall of the education park. In the hall, there is a platform for performance, a computer and a projection for presentation tables and many chairs. Furthermore, there are football, basketball and volleyball fields, and wide grass area at the outside of the park. 


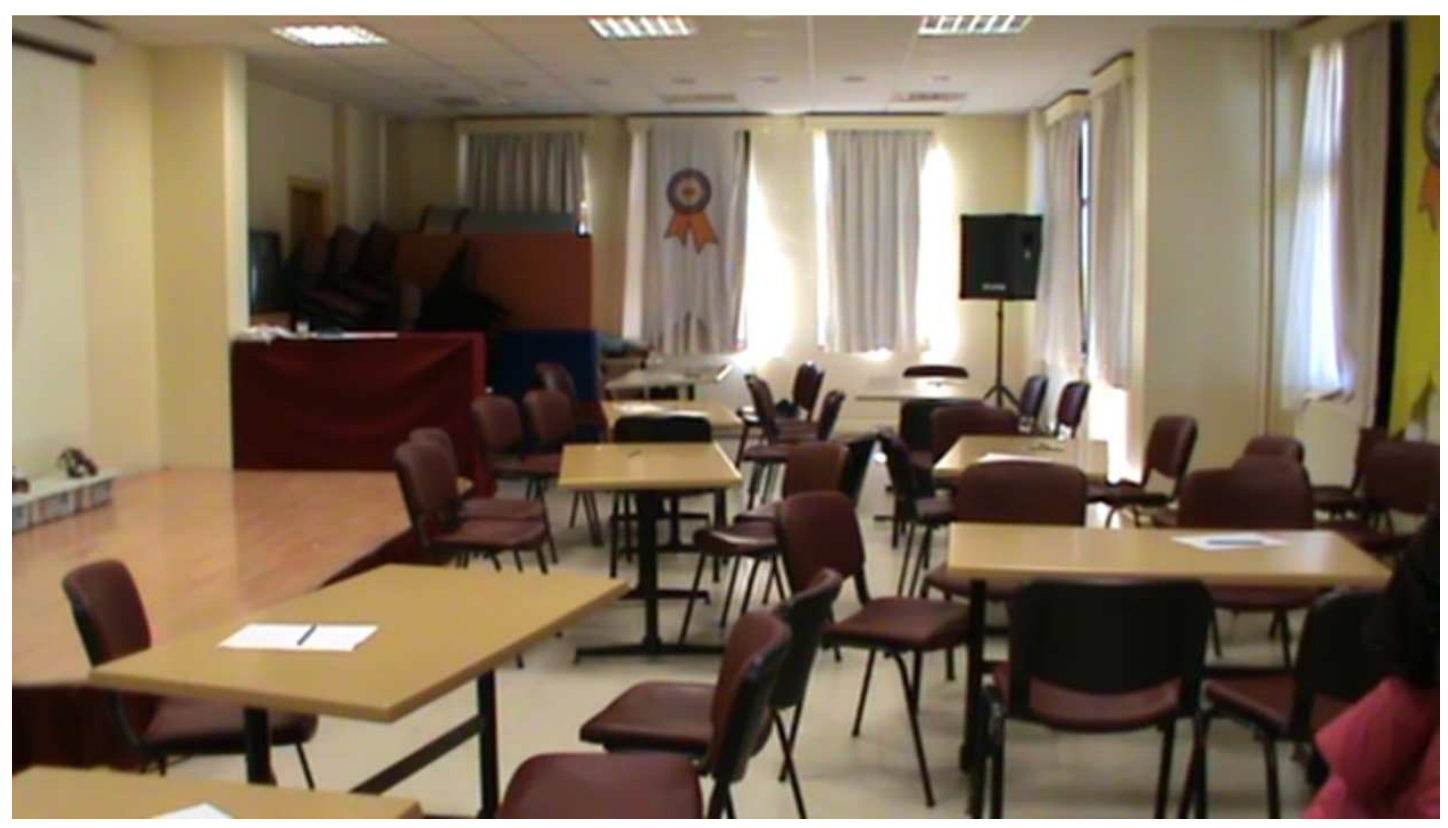

Figure 4.1 Picture of the hall

\subsubsection{Characteristics of the first camp}

Constructionist approach was driving learning philosophy of the first camp. Main purpose of the camp was to prepare environments and tools for children to discover about some science and math concepts from school curriculum. Since, it is impossible to implement robotic activities for all science and mathematics curriculum; $6^{\text {th }}$ grade science and math curriculum were analyzed and suitable concepts were chosen. Moreover, Carnegie Mellon University, Robotic Academy Curriculum was analyzed and appropriate concepts, their approach and relation with STEM curriculum (Science, Technology, Engineering and Mathematics) were evaluated. In addition, related literature about the usage of the robots in STEM curriculum was reviewed.

Educational Robotic Camp curriculum was prepared according to the results of these content analyses. In this curriculum, robotic education such as programming robot for specific rotation with three different tires was combined with the radius and circumference concepts in mathematics. So, the children firstly learned a piece of programming and then they applied that piece of programming to an activity which is related to science and math concept in school curriculum. Moreover, activity sheets 
were prepared for these activities, and they were consisting of some activity related questions and blank areas. It was expected that students answer these questions and fill the blanks with their measurements and calculations. Activity sheets are presented in the Appendix F, G, H, and I. Detailed explanation of the activities and their implementation will be explained day by day later in this chapter.

Some robotic competitions were prepared at the design of the camp curriculum. Aim of these competitions was just to increase motivation of the children and add some fun to the activities. The winner of the competition could not get any prize. Winner groups were only applauded by friends.

During the camp, number of instructors attended to camp changed day by day, therefore the instructors could not attached to one group, they walked around and they guided any group which needed guidance.

Three meals were given at the camp. Pastry and milk or juice as breakfast at around 10:30. Lunch breaks were mostly given around 12:30 to 13:30 and lunches were varied. Snacks, similar to the breakfast, were also given in the afternoon. Children were taken from their home by school buses in the morning and they returned back with the same buses to their homes.

The first six days of the camp were reserved for the robotics education, programming and science and mathematics activities. Following three days were reserved for the robotics project work. The last day of the camp, the children presented their robots to their family and friends. Detailed camp curriculum is presented in the Appendix E.

\subsubsection{Diary of the first camp}

\subsubsection{The first day $(25.01 .2010)$}

Children had already arrived and were waiting excitedly. Firstly, the instructors introduced themselves and then the children introduced themselves one by one. After a brief introduction about the camp and camp's rules, the children filled some pretest questionnaires which were requirements of the project. 
Short robot videos were presented by using projector. The aim of short videos was to gain their attention, increase their motivation towards the camp and show them what they would achieve at the end of the camp. After that, they watched a movie related to robots. Then, they discussed about what robots are, what the characteristics of a robot are, the difference between a robot and a remote control toy etc. until lunch break.

Afternoon session started with a game to form their groups for the rest of the camp. All children were acting like atoms and they walked around. With the command of the instructor they created a molecule with two, three or four atoms, that is each child linked his/her arm with the nearest stated number of the children. Lastly, they created molecule with four atoms and this molecule became their groups.

Later, colored pencils and papers were distributed to each group and they pictured the robot in their mind. Then, each group presented their robots' picture and its' functions. After the presentations, all pictures were hanged on a wall (see Figure 4.2)

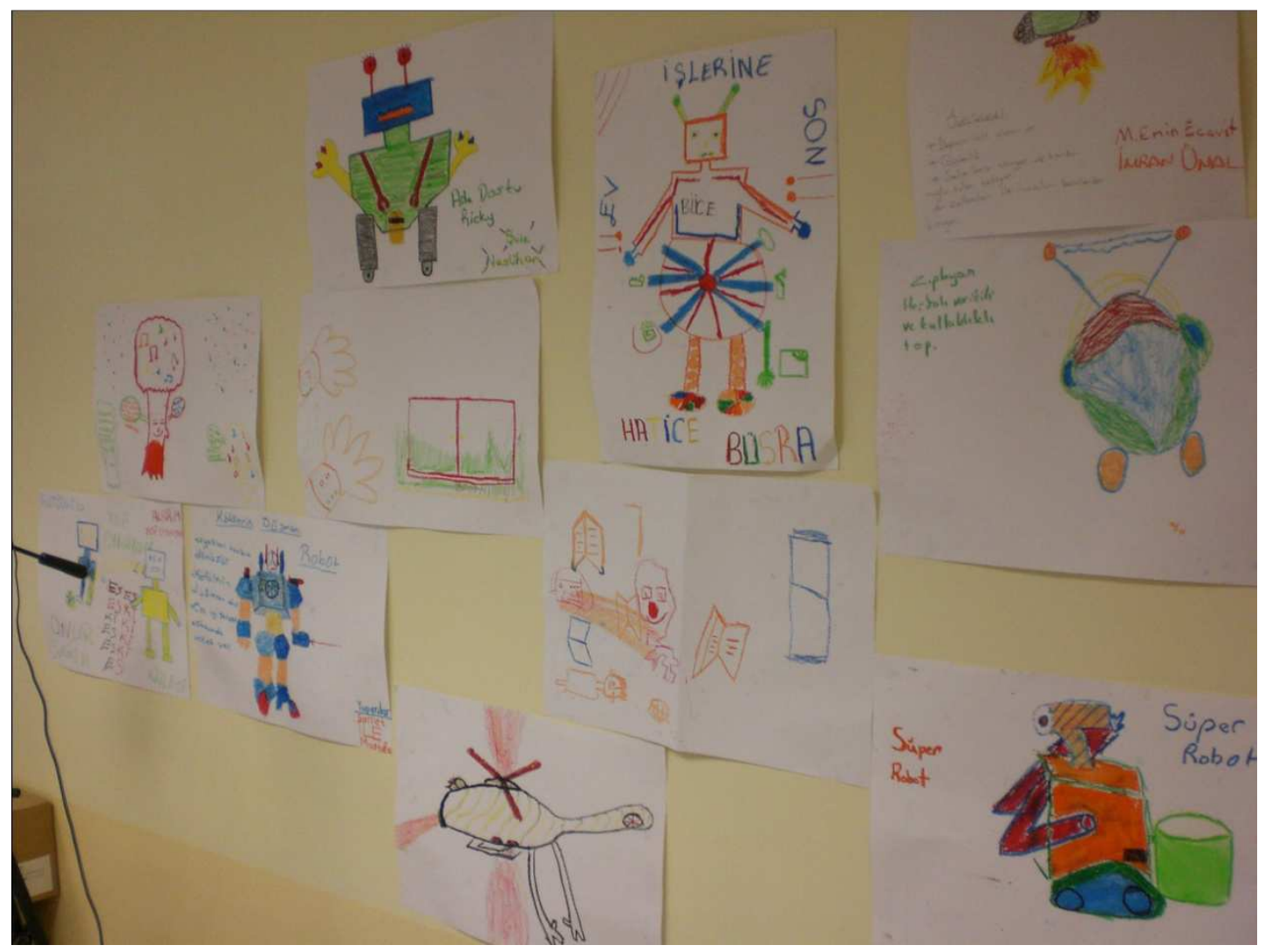

Figure 4.2 Robot pictures on the wall 
Around 14:00, Lego Mindstorms NXT sets were distributed to the groups. Sets were boxed and the children were the first ones to open them. Therefore, firstly they should arrange the pieces; they put the pieces cubicles of the boxes. They started to build their first robots according to the manual at 15:20. With the help of the instructors, they built their first robots and they made a simple program to move them. They did not use computer to program their robots, they made their program on the NXT bricks. They played and explored the NXT brick until 16:20 and then they picked up their robots and left the camp.

\subsubsection{The second day (26.01.2010)}

Around 09:45 children arrived to the camp. After taking attendance and explanation of the day's program, all instructors came to the platform to perform a drama. In the drama, each instructor acted as an object used to build robots. One acted as user, other one acted as computer, other one robot, wire etc. Children were asked what would be the programming steps if the robot (in this case one of the instructors) would go toward the wall, then when he saw the wall turn back and stop. According to the children's commands, all instructors performed drama.

Around 10 o'clock, after the drama, paper and pencil were given to each group and asked to write down programming steps for a security robot which goes until detecting an object, then turns back, goes straight until detecting another object and performs this action continuously. During the paper and pencil programming, instructors were pretending like robot. They took the paper, read the programs and acted how the robot should behave according to written program. Therefore, children could easily grasp if the program had bugs. Until the breakfast break (at 10:30), children could grasp basic understanding of the programming, sensors and surprisingly looping concept in programming.

After the break, NXT-G programming interface and blocks architecture of the program presented to the children by using wall projector. In NXT-G, to write a program for the NTX robot is very simple. Children do not need to write any code. 
By dragging and dropping the pre-defined blocks in sequence and adjusting each block properties, children can create a program. For 20 minutes, one instructor presented "move block" and its properties to the children. After then, children made some practice about move block and played with the robots until 11:25. As a practice, children were asked to create a program which moves the robot in perfect square shape. Until 12:00 every group finished this task by using eight move blocks. One move block used for going straight and one move block used for turning 90 degrees and that process repeated four times. Then, the instructor challenged the children whether they could make the same square drawing program with only three blocks. With little hint, some groups figured out to use loop block to make move and rotate process four time, other groups reached the same point with more support of the instructors.

Before the lunch break, all class evaluated what they have learnt so far then they went out for launch at 12:30.

After the lunch, activity sheets (see Appendix F) were distributed to the children. For this activity, three couples of different size tires were given to each group. For each tire, children measured the diameters and circumference of the tires, and they have found the required rotation to move the robot $50 \mathrm{~cm}$ by trial and error. They had noted what they had measured and found on the activity sheet. This activity lasted until the afternoon break (at 14:45).

After the break, there was a competition about this activity. Children had already found required rotation for $50 \mathrm{~cm}$ movement of the robot by trial and error. The competition was making a program to move the robot exactly 2 meters without any trial and error. The closest robot to the 2 meters line would be the first one and so on. This competition repeated three times for three different sizes of the tires.

After the competition, children picked up the parts of the robots and they left the camp at around 16:15. 


\subsubsection{The third day $(27.01 .2010)$}

After taking attendance, all class started to talk and joke about their daily routines. After this warming up talk, with the guidance of an instructor, the class discussed about how a robot could turn 180 degrees. As children stated, there are two ways to achieve that; a) one motor turns forward and the other one turns backward, and b) one motor stops and the other motor turns forward. After stating the second way of the turning, two instructors acted as motors of the robot; they stood close and walked together. At the end of the platform, one instructor stayed and other instructor turned around her. They performed same act, with wider space between them. After that, one child said that

\section{"takes a longer path" \\ "daha uzun yol allyor"}

Once children realized the difference, activity sheet at Appendix G were distributed to the groups. In this activity, children would measure the rotation of a tire to rotate the robot 180 degrees with three different distances between the tires.

While children were working on the activity, one journalist visited the camp and took information about the camp. This visit did not disrupt the children, because he did not carry a camera.

Until the breakfast break (at 10:50), children worked on the activity. Just before the break, the competition was announced. Competition was about making a program to move robot 2 meters and turn 180 degrees and move back to the starting point. The closest robot to the starting point would be the winner and so on. This competition was done twice with two different sized tires. After the competition, children left the class for the lunch at 12:50, half an hour later than the planned schedule.

Afternoon session started half an hour later than usual. So far, children had just programmed robot for movement. It was the time to start to a new concept, because students were getting bored. The next subject was sensors, after little talk about sensor; the children attached touch sensor to their robots by following the instruction given in the manual. 
When all of the groups attached touch sensors, how they should program the robot was presented with wall projector. They have learned, "wait for" block, which is used for waiting for a specific action such as until the touch sensor pressed then does defined action. Then, they were asked for programming their robots to go forward until they touch an object than turn backward and again go forward and so on.

Except two breaks at 15:00 and 15:50, children worked on their robots and programs. Some children did not even go out at the second break, and continued to work on their robots. After 16:15, they packed up their robots and filled the evaluation form given at Appendix B. At 16:30 they left the camp.

\subsubsection{The fourth day (29.01.2010)}

One of the directors of the project from the Science Education department attended to camp. However, four undergraduate instructors could not attend. There were four instructors at the fourth day of the camp.

The concepts of the day were velocity, displacement and time. Activity sheet in the Appendix $G$ was prepared for this subject. The children would measure the time for three different speeds of the robots (power at programming interface of NXT-G) for tree times and would calculate average speed of the robot. In the activity sheet, A-B distance was 8 meters. However, the platform at the camp area was shorter than this distance. As a result, all instructors agreed on using 4 meters for the distance between $\mathrm{A}$ and $\mathrm{B}$.

Firstly, they set motors' power to $30 \%$ and measured the time for 1 meter and 4 meters with chronometers. While measuring the time, there was only one platform, so there was a discussion about queue. The instructor from Science Education department collected one child from each group and made a small oral quiz to decide the queue for measurements of $50 \%$ powers and $100 \%$ powers.

When all of the groups finished the measurement for $30 \%$ power, they had a break at 11:11. After the break, the instructor gave information about velocity, displacement and time and their relations by using small white board. 
Before and after the lunch break, they continued to measure time for 50\% and $100 \%$ motor powers. When all the groups finished the measurement of time, the instructor noted all groups' average value on the board and discussed about measurement errors with the children.

The fastest robot tournament was that day's competition. Children were free to design and program. The race would begin with referee's whistle, therefore they used sound sensor for their design. Moreover, all groups used the biggest tires to get faster robot.

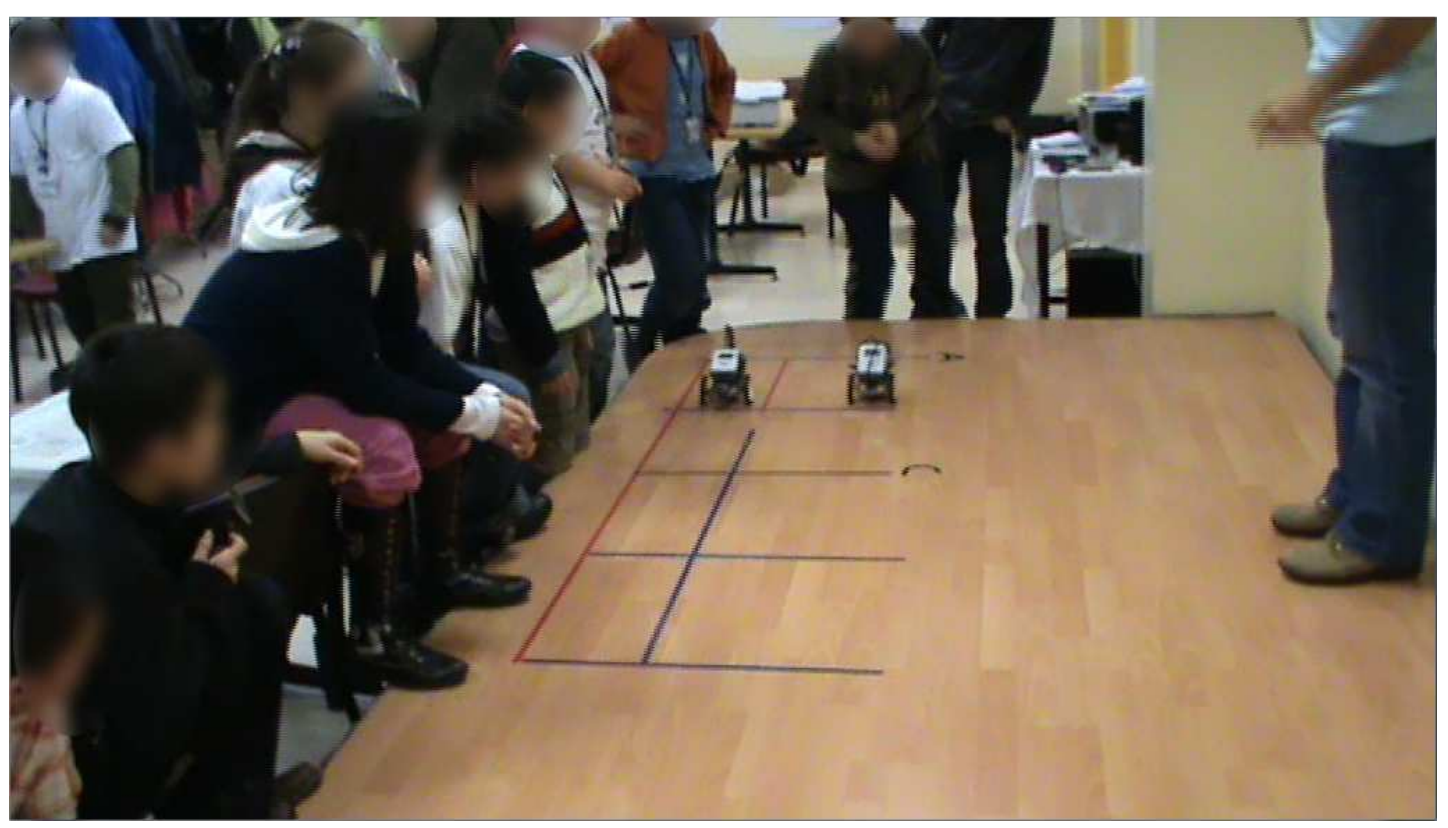

Figure 4.3 The fastest robot tournament

At the end of the tournament, one group was the champion but the hardest discussion of the camp started after the tournament. Other groups objected to get outside help. After the discussion, instructors thought about competitions one more time. Around 15:46, they packed up their robots and they filled the evaluation form (Appendix B).

\subsubsection{The fifth day $(01.30 .2010)$}

Most of the children had complained about the previous day's tournament and its results on previous day's evaluation forms. Therefore, the instructors started the day with a discussion with children. They tried to explain there was nothing at the end of competitions; they would not get any prize at the end. Why they gave so importance 
the result of the competitions. During the discussion, they voted to whether organizing more competitions or not and they decided not to organize another competition on that day. Moreover, they made some changes in groups because of complaints from the group members.

Around 10:00 o'clock children started to add ultrasonic sensors to their robots according to the NXT manual. When they finished, one instructor explained how they measure a sensor's value from the NXT screen. They measured the distance between an object and ultrasonic sensor and they filled the activity sheet (Appendix $\mathrm{H})$. The competition in the sheet was not made.

After the breakfast break (at 11:23), the children started to build a security robot which approaches to an object for $20 \mathrm{~cm}$, then turns back and goes straight until 20 $\mathrm{cm}$ to another object and continuously repeat these actions similar to the programming steps they had written on the second day of the camp. One of the instructors started to use the referee's whistle to get attention of the children and he continued to use the whistle until the end of the camp.

At 11:48, switch block was presented to children with wall projector. Switch block is equivalent of "if condition" in other programming languages. With switch block, if a condition is satisfied such as the value from ultrasonic sensor less than $20 \mathrm{~cm}$, then we can define the action of the robot and if it is not satisfied we can define another action. Later, the children made the same security robot's program by using switch block.

Until that time, they used only one sensor at a time. Then, they were asked to use ultrasonic sensor and touch sensor at the same time to design a robot which plays sounds while approaching to a wall like parking sensor and when it touches the wall it would stop. They started working on this robot before the lunch and finished at around 14:00.

In the NXT manual, there is a robot design which has an arm like jigger and it approaches to ball's platform, if the ball is blue then gives an error sound and goes back, however, if the ball is red it hits the ball. In this design, two sensors; ultrasonic 
and light sensor are used. They were assigned to follow the instruction in the manual and make that robot design.

Until the end of the day, children worked on this robot design and programed by following the instruction in the manual.

\subsubsection{The sixth day $(01.02 .2010)$}

They started by talking about what they have learned so far. They had finished one week of the camp and they were going to start the second week of the camp. As the time passed, the control of children was getting harder. One of the instructors stated that they would choose the group of day. The most noiseless and obedient group was going to be the group of the day.

There was no more activity sheet and the activities would be a bit improvisational. The first activity of the day was upgrading their security robots. The children were asked to make required change on their robots and programs to follow the line and play some sound in specific time intervals. They talked about how robots can follow a line, and which sensor they should use.

Until the breakfast break, children built required upgrade on their security robots by means of the light sensor; their robots can detect the dark line from the light background.

After the break, they were asked to make a robot which goes around in the area bordered with black line and pushes the randomly placed balls. They made a program which detects the black border with light sensor, when the robot reached the border, turns back and goes until to reach other points of the border and it does this action continuously. Robots pushed the balls when randomly meet the balls. Children added wide pushing arms to increase the chance of the meeting.

After the break, between 14:25 and 14:40, they started the last activity of the day. Last activity was like the previous one, the robot would go around the area but this time would not touch the balls (See Figure 4.4). 


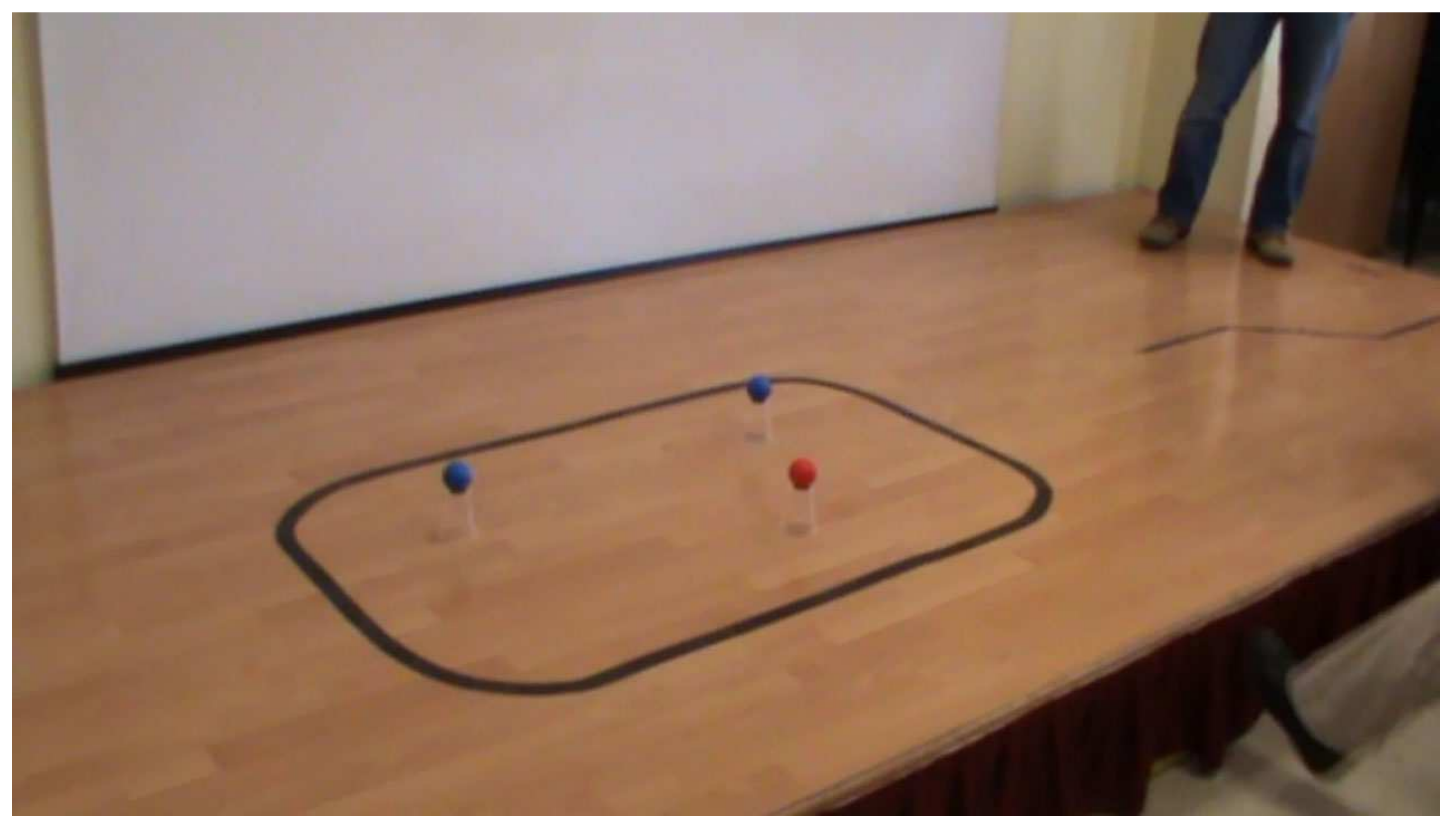

Figure 4.4 Activity area

They added ultrasonic sensor to detect the balls and did required change on the previous program to avoid the balls. Around 15:30, they packed up their robots and they filled the evaluation form (Appendix B).

There was last thing should be done, selecting the group of the day. All instructors collected together and picked a group because of their kindly behaviors. Prize was to have a Turkish flag on the table next day. Still they had thirty minutes; they went outside and played until 16:30.

\subsubsection{The seventh day $(02.02 .2010)$}

On the seventh day of the camp, the children started to work on their project. Firstly, approximately $2 \times 4 \mathrm{~m}$ area was bounded with black line on the platform. Also one corner of the area was defined as base (See Figure 4.5). For the project, it was asked them to design cleaning robots which would collect three cans and bring them to the base. They had three days to finish their project. 


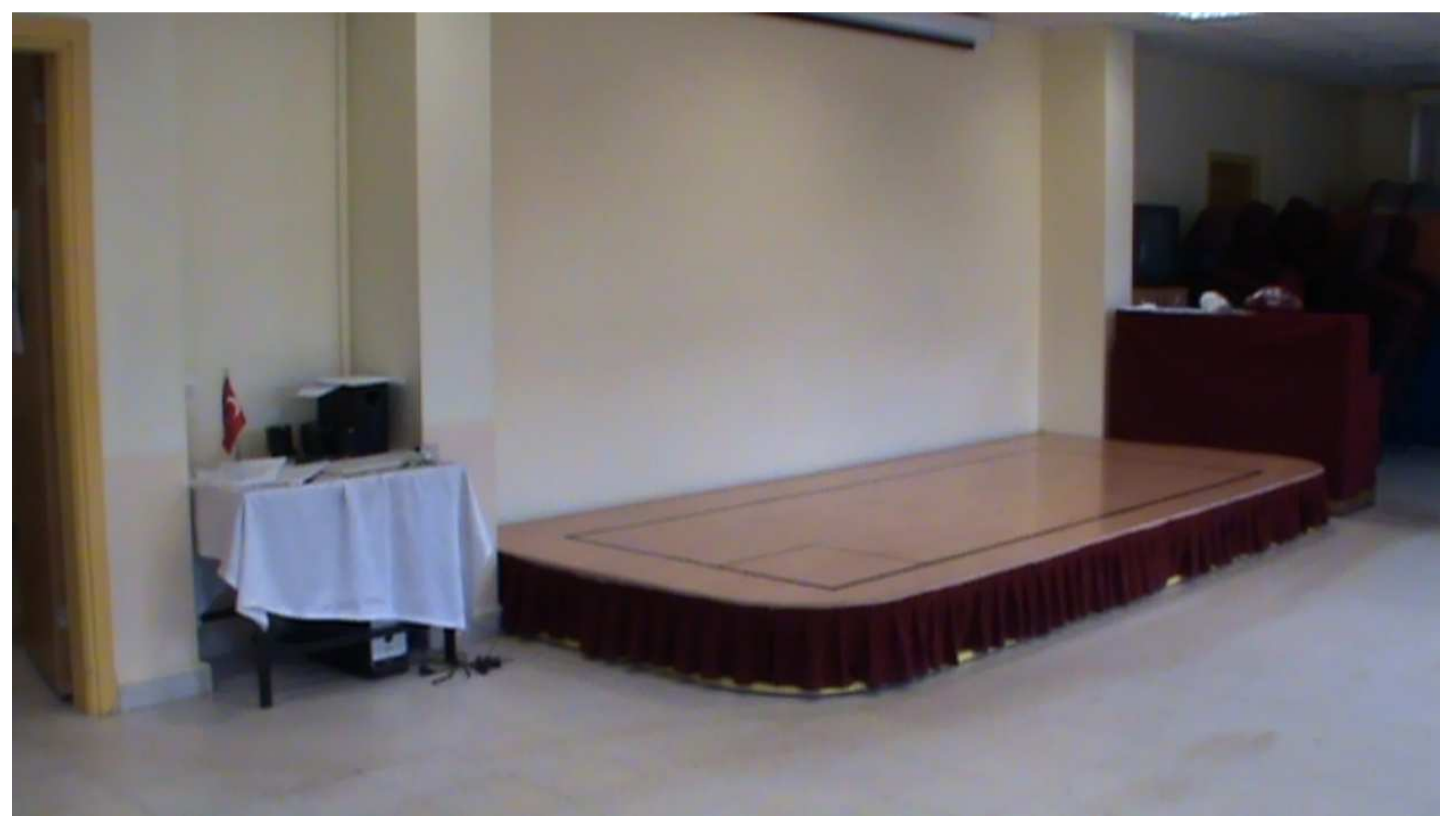

Figure 4.5 Project area

They worked on their projects until lunch break at 12:30 pm. A trip to Middle East Technical University's Science and Technology Museum had arranged for that day. After the lunch, they visited the museum; surprisingly the staff working on the museum started her presentation with a different kind of robot. Her robot was looking like a human with legs and arms. It made some acrobatic movements and danced. Then, she presented other scientific staff and made some interactive scientific experiments. After the museum, all children were given a ride to their home.

\subsubsection{The eighth day $(03.02 .2010)$}

Because they visited the museum on the previous day, the instructors had not selected the group of the day; first they picked the group of the day. Then, resource sets were distributed to groups. LEGO MINDSTORMS Education Resource Set includes plenty of special elements such as belts, unique connectors, a worm gear, and structural elements, as well as other LEGO elements such as beams, axles, and connectors. 
The children worked on their projects with the help of the instructors all day long. Two unusual things happened at that day; firstly, one of the instructors (the researcher at the same time) started to one to one interview with the children in a different room and secondly, one journalist visited the camp at 12:00. He took pictures of projects and children and got information about the camp.

They filled out the evaluation forms (Appendix B) for the last time. The instructors selected the group which would carry the flag next day and then they left the camp.

\subsubsection{The ninth day $(02.04 .2010)$}

One of the directors of the camp stated that it would be better if all groups present different robots than all groups' presentation of their cleaning robots. Therefore, they decided that all group continue to work on cleaning robots projects until noon, and then they would choose a robot design they had built before and rebuild that robots to present their family.

Children worked on the cleaning robots until noon. Some of the groups finished completely their design and program; however some of them did not. One of the finished cleaning robots design is shown in Figure 4.6.

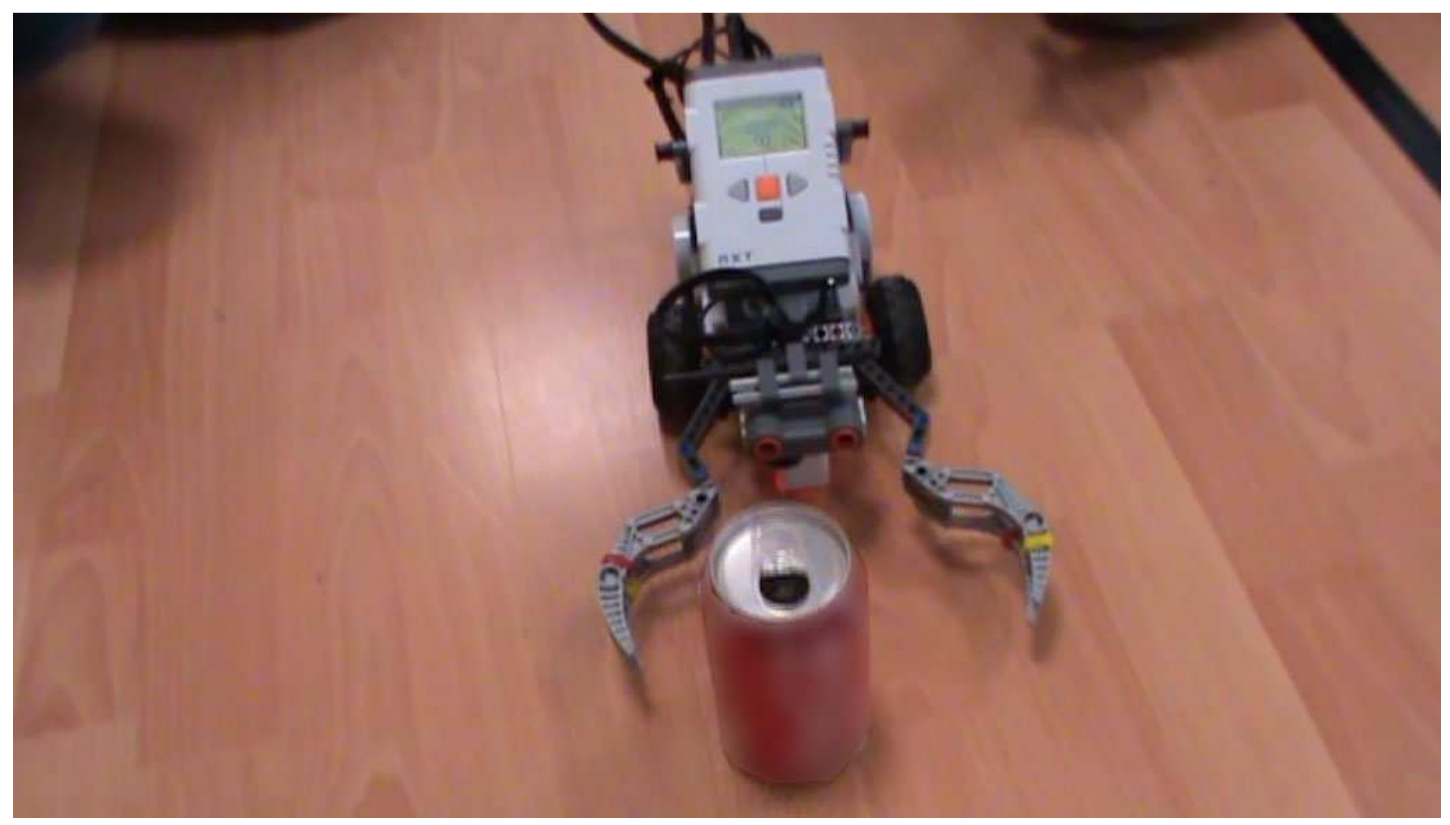

Figure 4.6 One of the cleaning robots 
After the lunch, children were asked to think about the robots which had been designed during the camp and which design they wanted to present to their family. Because, all groups should present different robots, they should choose which robot they want to present. Each group assigned different robots such as one group would present security robot and another group would present the robot hitting the ball.

They worked on their robots until 16:20, and then the group of the day was selected. Time of the school buses for the families was announced and they left the camp.

\subsubsection{The tenth day $(05.02 .2010)$}

One of the instructors showed a newspaper. They saw the newspaper story about the camp. They were quite interested in the story and their pictures. They made the last preparations on their robots until 11:20. Then, they filled some post-test questionnaires required for the project. At 11:40, they started to rehearsals. Each group would come to platform; each group member would introduce himself; they would present their robots and they would show the performance of the robot.

During the lunch break, the camp was cleaned and organized for presentations. In the meantime, reporters from a television channel had come to the camp and also they made their preparations.

All guests arrived and took their place in the hall and presentations started at 14:45 pm. They presented themselves and their robots as rehearsals. The families were quite interested in their children's performance. After the presentations, certificates of the participation were distributed to all children and the staff. Later, photos were taken and the camp ended at 15:30 of the fifth of February.

\subsection{Part 2: The Second Camp}

Before the second camp, the first camp results were evaluated and the curriculum was discussed with all instructors and the director of the project at two meetings. The meetings lasted around one and half hours on 16 June and 07 July.

Some changes were done on the curriculum as a result of these meetings. Firstly, the first camp was so crowded; therefore they decided to keep the number of children at 
24. There were six instructors and each group should have four children. Secondly, at the first camp the instructors walked between the tables and helped the children, for the second camp the instructors would attend the all camp and the number of the instructors would not change during the camp, therefore they decided to assign each group to an instructor. Thirdly, because they had some troubles about the competitions and contests, so they decided to minimize competitions. Fourthly, they decided to apply learning stations approach. Learning station is a center where the children try to reach objectives through predetermined activities (Ediger, 2011). They defined six half day long learning stations and each instructor would guide one station. The groups would visit all the stations during three days. Lastly, they allocated the first three days of the camp to programming that is the children would learn combining and programming of the robots, they would give everything about programming at the first three days. Then, they would start learning stations and work on for three days. Last four days were allocated for projects and presentations of the projects.

\subsubsection{The second camp}

Like the first camp, the second camp was also implemented at The Educational Volunteers Foundation of Turkey (TEGV) Semahat - Dr. Nüsret Arsel Education Park between $12^{\text {th }}$ and $23^{\text {th }}$ July 2010 with the support of The Scientific and Technological Research Council of Turkey (TÜBİTAK). The staff of the TEGV again organized the applications and acceptance of the children, took care of the nutrition and support of the place. 24 children from 6th, 7th and 8th grade attended to the second camp.

\subsubsection{Characteristics of the second camp}

Like the first camp, driving philosophy of the second camp was also consctructionism in which the children were supported to construct their knowledge by making. The instructors avoided giving direct solutions of the problems, they tried to encourage, scaffold and guide them to solve the problems.

Unlike the first camp, robots and programming were emphasized during the first three days of the camp. All robotics staff like combining, programming etc. were 
given without any integration with science and mathematics concepts. It was expected that, at the end of the third day the children would be competent about the LEGO Mindstorms NXT and its programming, therefore they can apply their knowledge to learning stations and their projects.

$4^{\text {th }}, 5^{\text {th }}$ and $6^{\text {th }}$ days of the camp reserved for learning stations work. Six different stations were prepared by the instructors. Each station was designed for half day long and each station was guided by an instructors. Different mathematics and science concepts were studied at these stations. A group visited a station at morning session and move to other station at afternoon session. Therefore, all groups visited and worked at all stations during these three days.

\subsubsection{Participants}

Twenty two children at different grade levels attended to second camp. In the design phase of the second camp, the instructors had not been informed about grade levels of the children and they had been thinking that the $6^{\text {th }}$ grade students would attend the second camp, like the first one. They prepared the instruction especially the stations for the $6^{\text {th }}$ grade. However, the grade levels of the participants varied in the second camp. Participants' gender and grade levels are shown at Table 4.4.

Table 4.4

Gender and grades of the second camp's participants

\begin{tabular}{lcc}
\hline Grade & Boys & Girls \\
\hline $6^{\text {th }}$ & 2 & 3 \\
$7^{\text {th }}$ & 8 & 3 \\
$8^{\text {th }}$ & 1 & 5 \\
\hline
\end{tabular}

Participant of the second camp were more from diverse schools contrary to the first camp. In addition, three children attended from governments special dormitories for divorced parents' children. Because of the existence of the children without families, 
the researcher excluded the interview questions related to family (father and mother's occupation and number of the siblings) from the interview schedule. Like the first camp, nick names were given to the participants according to camp and interview order. Participants' and their demographics are shown at Table 4.5. 
Table 4.5

Participants of the second camp

\begin{tabular}{|c|c|c|c|c|}
\hline Nick name & Gender & Grade & School & $\begin{array}{c}\text { Any Lego toy } \\
\text { experience }\end{array}$ \\
\hline Kid.II.01 & Boy & $8^{\text {th }}$ & Merkez 50. Y11 İzzet Baysal İO - Public & Yes \\
\hline Kid.II.02 & Boy & $6^{\text {th }}$ & Teyfik Fikret İO - Private & Yes \\
\hline Kid.II.03 & Girl & $8^{\text {th }}$ & Kazım Krabekir İO - Public & Yes \\
\hline Kid.II.04 & Boy & $7^{\text {th }}$ & Kadri Suyabakan İO - Public & No \\
\hline Kid.II.05 & Girl & $7^{\text {th }}$ & Mesa Koru İO - Public & Yes \\
\hline Kid.II.06 & Girl & $7^{\text {th }}$ & Etimesgut İO - Public & Yes \\
\hline Kid.II.07 & Boy & $7^{\text {th }}$ & Sevgi Çocuk Yuvası - Dormitory & Yes \\
\hline Kid.II.08 & Girl & $8^{\text {th }}$ & Köy Hizmetleri İO - Public & Yes \\
\hline Kid.II.09 & Girl & $8^{\text {th }}$ & Ağa Ceylan İO - Public & Yes \\
\hline Kid.II.10 & Boy & $7^{\text {th }}$ & Sevgi Çocuk Yuvası - Dormitory & No \\
\hline Kid.II.11 & Boy & $7^{\text {th }}$ & Koç İO - Public & Yes \\
\hline Kid.II.12 & Girl & $6^{\text {th }}$ & Sakarya İO - Public & Yes \\
\hline
\end{tabular}


Table 4.5 (continued)

\begin{tabular}{|c|c|c|c|c|}
\hline Kid.II.13 & Boy & $7^{\text {th }}$ & Şeyh Şamil İO - Public & Yes \\
\hline Kid.II.14 & Girl & $6^{\text {th }}$ & Etimesgut İO - Public & No \\
\hline Kid.II.15 & Girl & $6^{\text {th }}$ & Etimesgut İO - Public & No \\
\hline Kid.II.16 & Boy & $7^{\text {th }}$ & Eryaman İO - Public & Yes \\
\hline Kid.II.17 & Girl & $7^{\text {th }}$ & Etimesgut İO - Public & No \\
\hline Kid.II.18 & Boy & $6^{\text {th }}$ & Sevgi Çocuk Yuvası - Dormitory & No \\
\hline Kid.II.19 & Girl & $8^{\text {th }}$ & Zekiye Güdüllüoğlu İO - Public & No \\
\hline Kid.II.20 & Boy & $7^{\text {th }}$ & Nurettin Ersin İO - Public & Yes \\
\hline Kid.II.21 & Boy & $7^{\text {th }}$ & Ankara TED Koleji İO - Private & Yes \\
\hline Kid.II.22 & Girl & $8^{\text {th }}$ & Ahi Evran İO - Public & Yes \\
\hline
\end{tabular}




\subsubsection{Instructors}

All instructors who had attended to the first camp also attended to the second camp with the experience of the first camp. Moreover, the instructors who had been at final year of the university had graduated and they attended to the camp as qualified teachers. In addition, all of the instructors could attend the everyday of the camp.

\subsubsection{Diary of the second camp}

\subsubsection{The first day (12.07.2010)}

All the children had sat and were waiting. The t-shirts, prepared for the camp were distributed to children and the instructors. Videos from the first camp and a video captured a TV channel news about the first camp were presented to the children to get their attention. After a little briefing about the camp rules, the groups were assigned randomly. One of the directors of the camp gave numbers 1, 2, 3, 4, 5, and 6 to each child in queue and repeated that four times. Then, all 1's made the group 1 and so on. Therefore, all groups were defined. They went out for the breakfast at 09:30.

After the breakfast the children filled pre-test questionnaires until 10:15 and then they had another break.

They started the discussion of what a robot is at 10:30. Two characteristics of the robots were emphasized which are programmable and interact with the environment. Each group set down their table and one instructor assigned to each group. The robot sets were distributed and the children explored the components of the sets with the guidance of the instructors. Then, they constructed a simple NXT robot (Domabot (Kee, n.d.)) with the help of a construction sheets (Appendix K). After the break at 11:20, they learned how to turn on, turn off and programming buttons on the NXT Brick and started to program the robots on the brick (without using computer). Until the lunch break at 12:15, they worked on programming.

After the lunch break, between 13:10 and 14:15, they continued programming the robots on brick. However, this time they used the ultrasonic, sound and touch sensors 
on their robots and programs. After the break for snack at 14:15, they collected the robots and played some physical games, such as tug of war and charade.

\subsubsection{The second day (13.07.2010)}

The children arrived to the camp at 8:45, and then they took their robots sets. The robots they build yesterday were so simple, they broke up the robots and they built their robots according to the manual until 9:40 (Figure 4.7). In the meantime, the instructors changed their groups; that is for the morning session they worked with different groups. After the breakfast, they started to NXT-G programming interface and blocks architecture of the program was presented. Therefore, they started to program their robots at the computer, sent to the program to the robots and run the program on the robots. Except the break between 11:00 - 11:15 they worked on programming and learned move, record/play, sound, display and wait blocks until the lunch at 12:15. One instructor presented what these blocks are, how they can use these blocks and asked them to create a specific program by using these blocks.

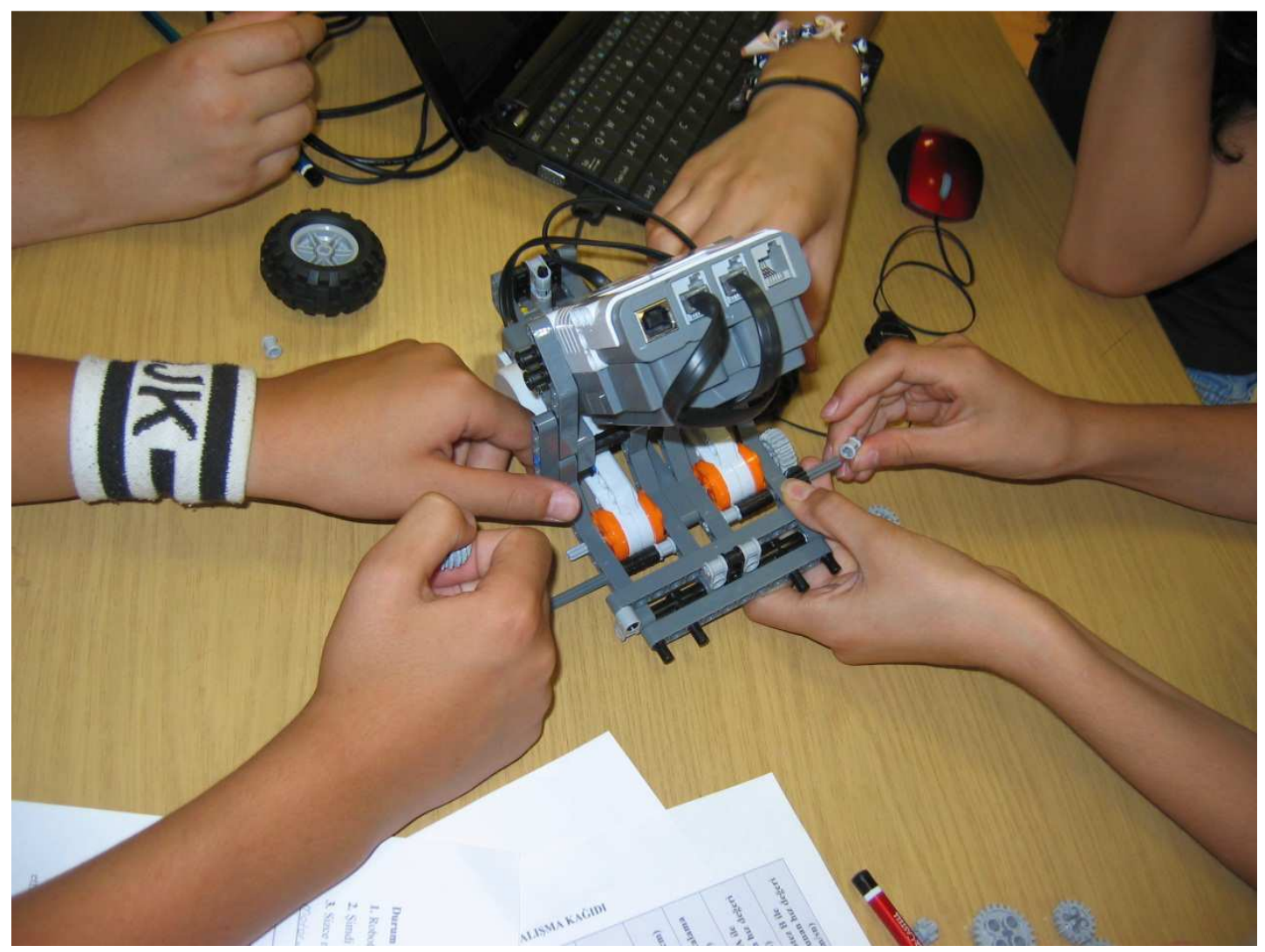

Figure 4.7 Children are building their robots. 
Afternoon session started at 13:40, the instructors changed the groups they worked with and they continued to work on programming. Sensors, parallel processing, switch and loop concepts were described and programs were done by the children about these concepts. Two children decided not to attend the camp anymore because of personal reasons. The camp was ended at 15:00.

\subsubsection{The third day (14.07.2010)}

The camp was started at 8:40 by taking attendance, and then they reviewed what they had learned about programming. Until the breakfast break at 9:30, they worked on the robots to follow the black line, with the light sensor.

After the breakfast, they started to work on a bit advanced concept, making connection with a wire in the program. With the wires, value of a variable can be transferred by one block to another one, such as sound level from a sound sensor can be transferred as input power level for the motors. Therefore, the robot can move slowly in silent environment and move faster in loud environment. After the break between 10:30 and 10:50, they made an arm to their robots according to NXT manual. They would make golf playing robots like the first camp. That day, the lunch was arranged a bit earlier than usual and they give lunch break at 11:00.

Afternoon session was started at 12:30; they programmed the robots for hitting the red ball and giving error sound for the blue ball. After the break between 13:15 and 13:35, some programming hints like exiting from a loop and cleaning the memory of the NXT were explained. Lastly, they made a program to write the values of the sensors to the NXT screen. Snack break was given at 14:00. When all groups finished the programs, they were asked to break up their robots, because the next day learning stations would start. They filled out the camp evaluation form (Appendix B) for the first three days of the camp. They left the camp at around 15:00.

\subsubsection{Learning stations (15-16-19.07.2010)}

Six half day long learning stations were prepared. Each groups visited all the stations during these three days. This time, instructors and stations were stationary and groups were mobile. Like the previous days, the camp started at 8:40 and finished at 
around 15:00. The breaks were like usual during these three days. At the end of the sixth day they also filled the evaluation form (Appendix B).

At each station, different science and mathematics concepts were examined with the help of the robots.

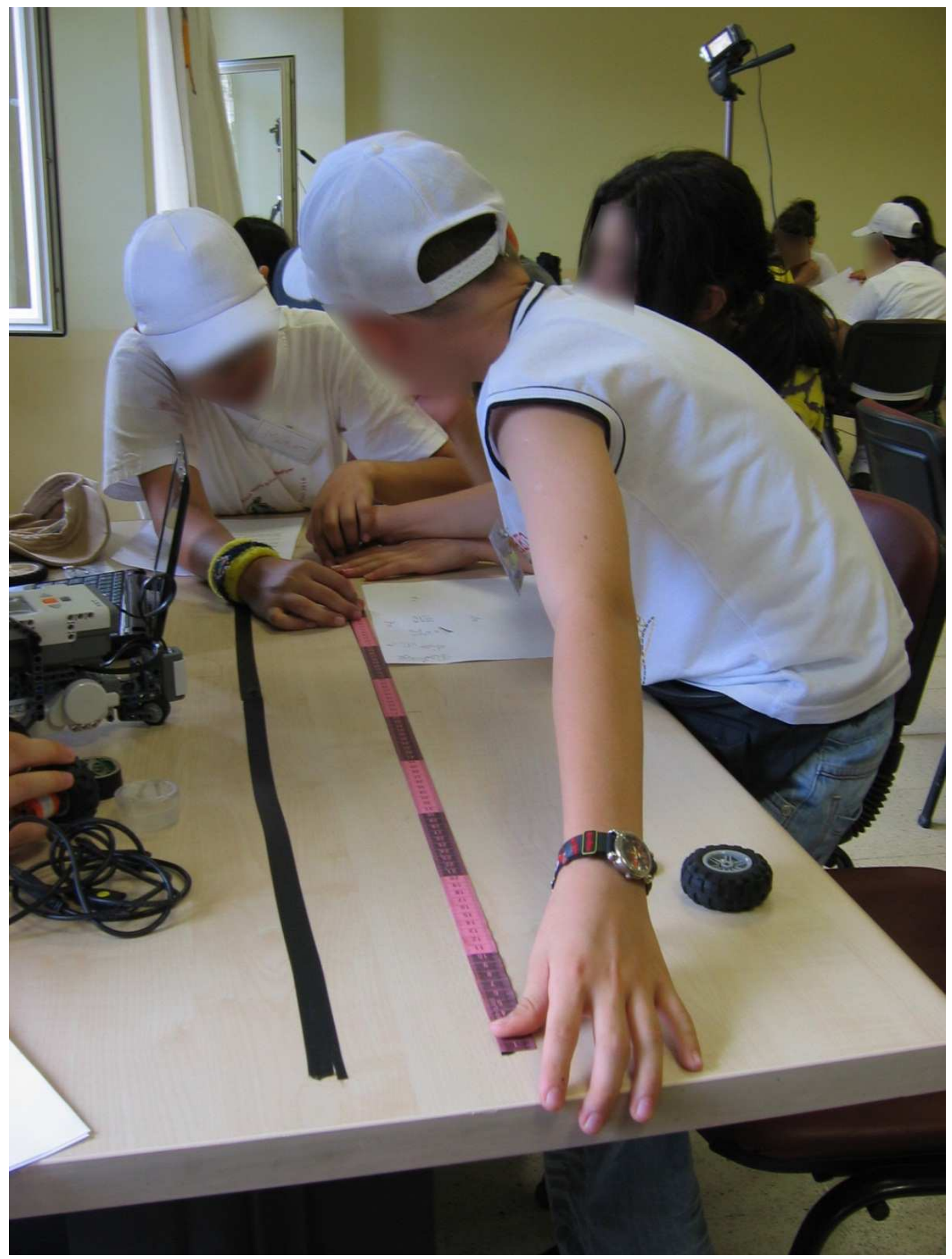

Figure 4.8 Children are working at a learning station 


\subsection{Geometrical shapes station}

In this station, the children worked on geometrical shape concepts which are triangle, square, rectangle and circle. They firstly, discussed about the characteristics of these shapes then they made required calculations and programmed their robots to draw these geometrical shapes.

\subsection{Circumference -pi station}

Aim of the station was to teach (or review) radius, diameter, circumference pi and distance and their relations. The instructor reviewed the children knowledge about these concepts and then the children measured and filled the activity sheet (Appendix J)

\subsection{Gear station}

The children discovered the relation between the sizes of a gear and its' effects on the velocity of the robots. The children tried different sized gears to transmit the motion from motors to wheels and measured the velocity of the robots.

\subsection{Sound station}

They have learned sound and the characteristics of the sound such as sound waves and frequency. The children built a theremin (a musical instrument controlled without touch) with two light sensors and simple org with eight touch sensors.

\subsection{Velocity station}

The children examined the velocity, distance and time relations at this station. With the different power level of robots, the children measured the time for $2 \mathrm{~m}$ and $3 \mathrm{~m}$ distances, wrote down their notes to activity sheet (Appendix $\mathrm{H}$ ) and drew the distance versus time graphics.

\subsection{Sensors station}

The children measured the data from rotation, sound, light and ultrasonic sensors and evaluated their graphics with the help of the NXT 2.0 Data Logging software. They 
programmed the robots to collect the data, transferred the data file to the computer and discussed about the measured data.

\subsubsection{The seventh day $(20.07 .2010)$}

They were scheduled to start their projects at that day. Therefore, they started with discussion about their projects. Some of the children already had ideas about their projects, however the rest had not. Until 09:30, the breakfast break, they were let to discuss about their project with the guidance of the instructors. Each group had an instructor and they would not change until the end of the camp.

After the break, each group presented their project idea, their robot's mission, and which sensors they would use. Then, they started to work on their projects. Meantime, the extension packs were distributed to the groups. At 11:30 lunch break was given.

Afternoon session started at 13:10 and lasted until 15:15. Except a long snack break (it lasted half an hour) they worked on their projects.

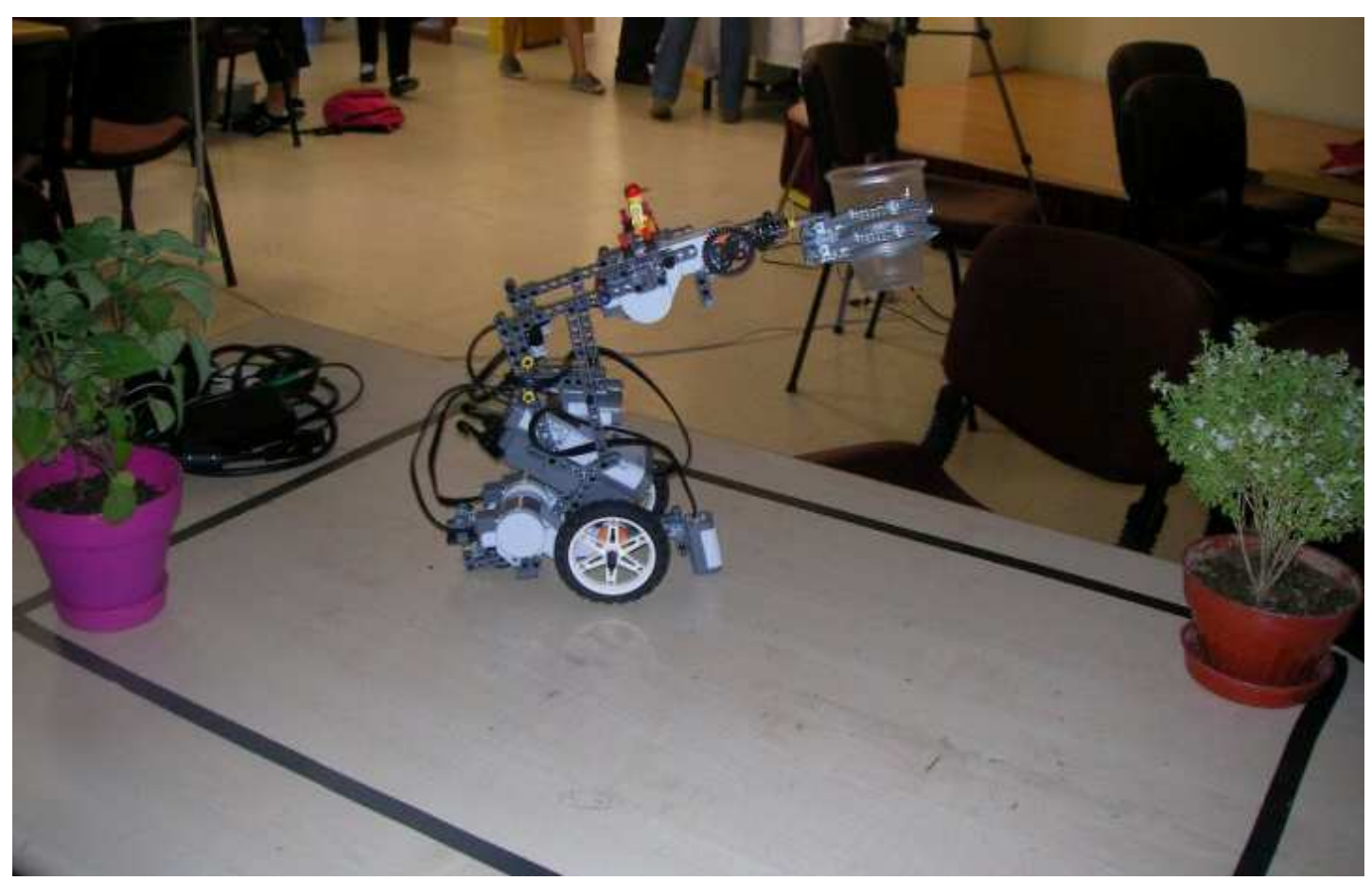

Figure 4.9 One of the projects: irrigation robot 


\subsubsection{The eighth day (21.07.2010)}

They continued to work on their project as usual schedule; the camp was started at 08:40 and finished at 15:10. Except the previous day, a journalist visited to the camp, asked questions about the camp, how they feel etc. The children presented to her their robots as much they had built.

\subsubsection{The ninth day $(22.07 .2010)$}

The children continued to work on their projects on the scheduled time. The researcher started to one to one interviews with the children in a private room. At the end of the day, they filled the evaluation form (Appendix B).

\subsubsection{The tenth day $(23.07 .2010)$}

The camp started at 8:40 as usual, the children wrote down what they would say during the presentation and memorized their cues. Then, each groups came to the platform and made rehearsal because, afternoon they would present what they had built to their families. Other students and instructors at the education park visited the camp and children gave information about their projects. At 10:30 the required posttests were distributed to the children, they filled them until lunch time.

During the lunch break, the camp area was cleaned and rearranged for the families. At 13:10, the education park's manager and then the project manager gave little briefing about the camp. Later, all groups presented their robot and showed their performance. After distribution of the participation certificates, the photos were taken and the camp ended around 14:30. 


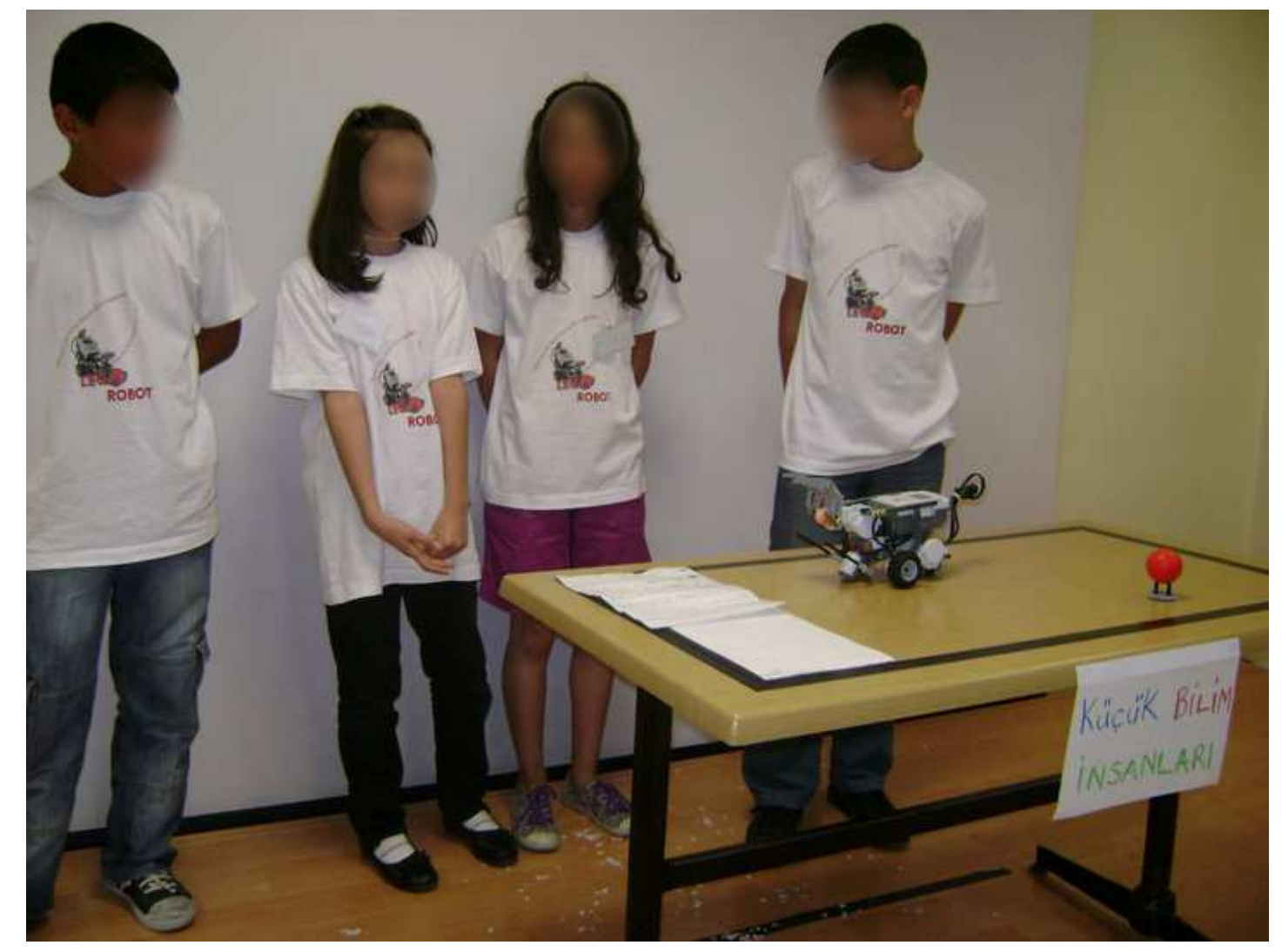

Figure 4.10 One of the groups presenting their robot project

\subsection{Part 3: Data Presentation}

This part presents the findings of the interviews with children from both camps, interviews with instructors, observations, evaluation forms and field notes. Variableoriented (Miles \& Huberman, 1999) strategy is used while presenting the results. When a researcher look for themes that cut across cases, it is better to choose variable-oriented strategy than case-oriented one. Thus, the researcher looks for the design principles for an educational robotics training camp, data are represented in variable-oriented approach. According to research questions emerged categories and themes from both camps are presented.

After the second camp the researcher and the instructors (one of the instructors could not attend) conducted a group interview to evaluate mostly instructional issues of both camps. It will be nonsense to assert that the first camp was better than the 
second one or vice versa. Each camp had positive components or better instructional values than the other. Therefore, instructors compared each camp according to issues related to research questions. Themes and categories are also supported with instructors' evaluations about the concepts.

Because the number of the children attended to camps was not the same, 30 children attended to the first camp and 22 children attended to the second camp, additionally percentage of the children (\# of the children / total number of the children x 100) also presented in tables for each themes and categories. Figure 4.11 presents overview of the themes and categories and their relations. 


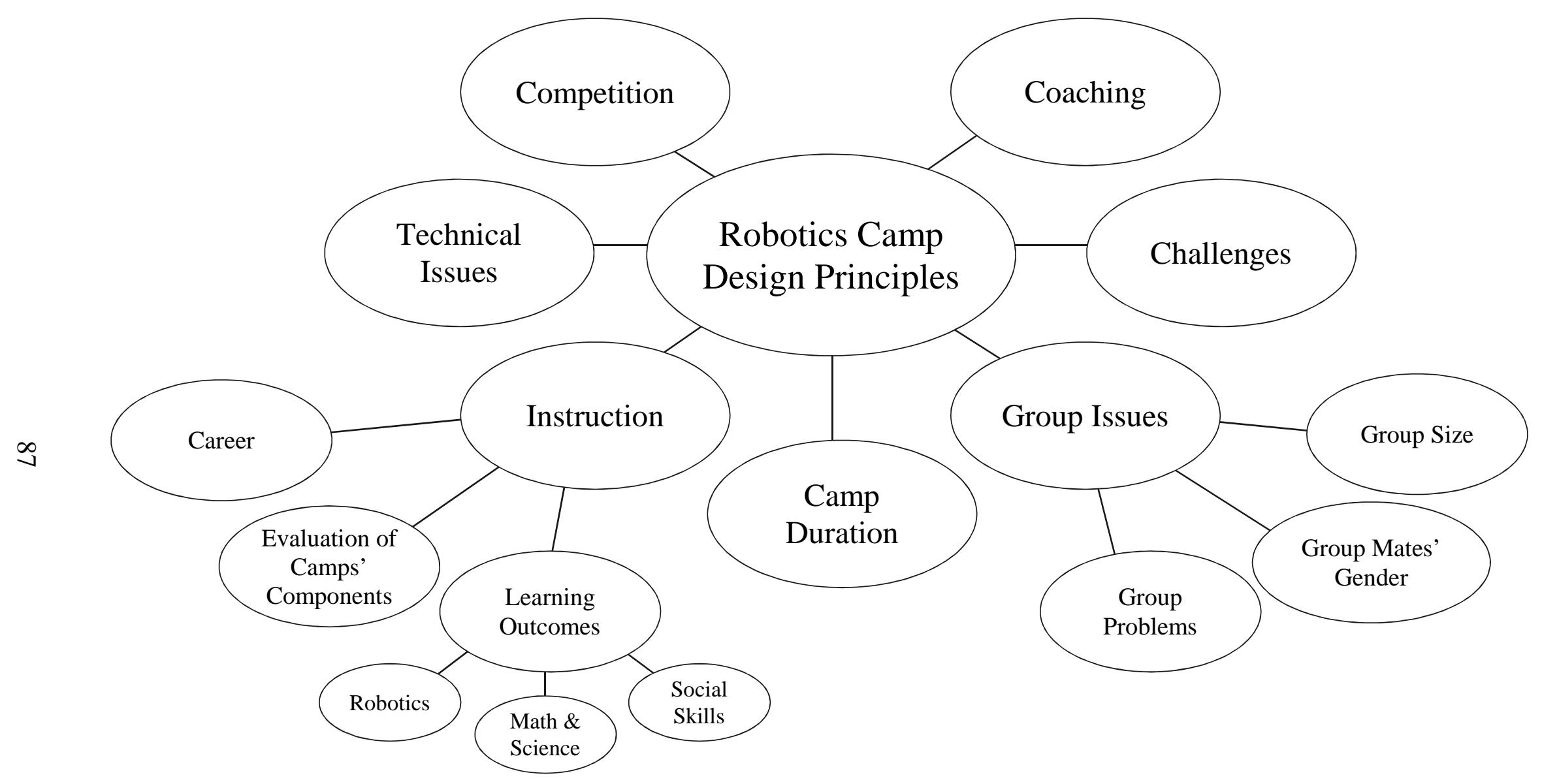

Figure 4.11 Concept map of the themes and categories 


\subsubsection{Instruction}

The first sub-question is how the instruction should be structured for a robotic camp. After the analysis of data, three categories emerged as the instructional aspects of the robotic camp which are learning outcomes, evaluation of the camps' components, and career.

\subsubsection{Learning outcomes}

Learning outcomes theme emerged with similar categories from both camps. The children expressed their learning outcomes from the camps three different categories which are robotics, mathematics and science and social skills. Robotics category covers all robotic related outcomes, similarly mathematics and science category covers the mathematics and science related robotics activities and children's outcome from these activities and social skills category covers social outcomes of children from both camps.

\subsection{Robotics}

During both camps, it was observed that children got accustomed to robot concept. For example, when they were talking or working, they were using robot related words properly or they know the properties of each sensors and how the sensors should be used. Except one of the children, the children had not touched a robot before. All children stated that they have learned robotics at the camp. Sometime they expressed their learning with general words like "I have learned robots"; sometimes they used more specific words such as sensors, programming etc.

Table 4.6 presents the frequencies (number of the children mentioned about related sub- categories) of robotics related sub-categories from the interviews with children and camp evaluation forms from both camps. 
Table 4.6

Robotics

\begin{tabular}{llccccc}
\hline \multirow{2}{*}{ Category } & Sub-category & \multicolumn{2}{c}{ I. Camp } & \multicolumn{2}{c}{ II. Camp } \\
& & $\#$ & $\%$ & $\#$ & $\%$ \\
\hline \multirow{3}{*}{ Robotics } & General robotics knowledge & 9 & 30.0 & 5 & 22.7 \\
& Programming & 17 & 56.7 & 21 & 95.5 \\
& Sensors & 19 & 63.3 & 11 & 50.0 \\
& Mechanic & 11 & 36.7 & 5 & 22.7 \\
\hline
\end{tabular}

\subsection{General robotics knowledge}

The children worked on robots during ten days, as a result of it they got to know what a robot is and its characteristics. During the interviews and evaluation forms they used mostly more specific terms such as programming, sensors etc.; however nine children from the first camp and five children from the second camp used general term "robots" while expressing their robotics content knowledge, the children stated that they have idea about what robots are and what they can do.

Kid.I.22 mentioned his robotics content learning as:

$R:$ So, do you think that it was useful for you?

Kid.I.22: Yes, I think.

$R:$ For example, what usefulness it has?

Kid.I.22: For instance, formerly when someone mentioned about robots, I did not know what it is. Now I can answer lots of questions instantly. I can even make a robot myself if I have program.

R: Peki sana faydası olduğunu düşünüyor musun?

Kid.I.22: Evet. Düşünüyorum.

R: Mesela ne gibi faydası olmuştur.

Kid.I.22: Mesela bana robot dedikleri zaman eskiden ben ne diye bakardım. Şimdi robot hakkında bir soru sorsalar hemen cevaplarım. Bir robot yapabilirim tek başıma program falan olsa.

Likely, Kid II.16 expressed his benefit from the camp with general terms about robots as: 
$R:$ Ok, do you think that the camp was beneficial to you?

Kid.II.16: Yes, I do.

$R:$ For example, what kind of benefits?

Kid.II.16: I learnt what robots can do. I learnt that I can make a robot too.

R: Peki kampın sana faydası olduğunu düşünmüyor musun?

Kid.II.16: Düşünüyorum.

R: Mesela ne gibi faydası olmuştur?

Kid.II.16: ...Ondan sonra robotların neler yapabileceğini öğrendim. Kendimin de bir robot yapabilece ğimi öğrendim.

Similarly Kid.I.19 reflected his robotics content learning in evaluation forms as;

Kid.I.19: Positive things are that we came here and learned lots of important things and learned about robots. We learned how to make a robot too.

Kid.I.19: Olumlu olaylar, bizim buraya gelip önemli şeyleri ögrenmemiz ve buraya gelerek bütün bilmediğimiz o robotları yaparak, robot yapmayı da ögreniyoruz.

The children get basic understandings about robotics because they worked with robots during ten days. Although most of the children stated their robotics knowledge with more specific words such as sensors and programming, some of children stated their general understandings about robotics. This instructional outcome of a robotics camp is called general robotics knowledge under robotics category.

\subsection{Programming}

One of the most stated learning outcomes of both camps was learning of the robot programming. Most of the children (17 of 30 children from the first camp and 21 of 22 children from the second camp) expressed that they have learned robot programming at the camp. Moreover, it was observed that children can grasp "loop" concept so easily that impressed the researcher. Although most of them had just basic level computer literacy, they stated that they have learned programming in the camps.

Kid.I.20: I have learned how to program too. For instance, I was very interested in computers. Before these activities, I did not know so many things at the beginning... I have learned programming too. 
Kid.I.20: Program yapmayı da öğrendim. Mesela ben bilgisayar ile çok ilgileniyordum. Önceden. Ama bu kadar bilmiyordum. Ilk başlarda... programlamayı da ögrendim.

Kid.I.14 has aware that the camp was a chance to learn robotics and programming.

She stated learning outcomes of the camp as:

$R:$ So, in this duration do you think you have learned something?

Kid.I.14: Yes.

$R:$ For instance, what you have learned?

Kid.I.14: A lot of people do not have power to make robots while sitting at their homes. This is reality. We came here and learnt how to make these robots. In fact, here we have learned lots of things that we could not learn at outside.

R: Peki bu süreçte bir şeyler öğrendiğini düşünüyor musun?

Kid.I.14: Evet.

R: Mesela neler öğrendin.

Kid.I.14: Yani birçok kişi evde oturup da robot yapmaya gücü yok yani. Bu bir gerçek. Biz buraya gelerek işte robotları programlamayı öğrendik. Dışarıda öğrenemeyeceğimiz bir sürü şeyi öğrendik diyebiliriz aslında.

Also, they stated learning of programming in the evaluation forms.

Question: Today what have you learned in the activity?

Kid.I.03: We have learned how to make a program for our designed and built robot to go straight and return when it meets an obstacle and then a program for our robot to walk inside an area and throw balls inside it without going outside.

Soru: Bugün etkinlikte neler öğrendiniz?

Kid.I.03: Tasarlayıp kurguladığımız robotun normal olarak ilerleyip bir engel görünce dönmesi için gerekli olan programı, sonra robotumuzun verilen alan içinden çıkmadan, topları çıkarması için gerekli olan programı yapmayı ögrendik.

During first three days of the second camp the children focused on programming, they built a basic robot according to manual and then they just worked on the programming during the first three days of the second camp. Therefore, the programming aspect of robots was more emphasized at the second camp. As a result 95\% of the children at the second camp stated that they have learned programming of the robots also in evaluation forms. This was something new even for students who identify themselves as familiar or good at computers. 


\subsection{Sensors}

NXT Education basic set which was used in the camps comes with one light, one sound, one ultrasonic and two touch sensors. One of the important characteristics of the robots different from any remote controlled device is their interaction with the environment. This interaction occurs through sensors. Therefore, sensors are the one of the important parts of the robots that makes robots as robots. Like the researcher, the children had heard the sensors like parking sensor but they hadn't a work with them before. During the camps they worked with all of the sensors in the set. Nineteen children at the first camp and eleven children at the second camp stated their learning of sensors, mostly in the evaluation forms. In their statements it can be seen that they did not state like "I have learned the sensor" they gave detail about characteristics of the sensor and how they used that sensor.

\section{$R:$ How is robot camp?}

Kid.I.15: It is very beautiful and entertaining. I had not known light sensor, ultrasonic sensor but now I have learned. We see some places with light sensor. It returns when it sees black bands. With ultrasonic sensor; if it sees obstacles, it has hands and lifts cans.

\section{R: Robot kampı nasıl?}

Kid.I.15: Çok güzel eğlenceli. Hiç tanımadığım ışık sensörü var, ultrasonik sensörü hiç bilmiyordum ama şimdi öğrendim. Işık sensörü ile bazı yerleri görüyoruz. $O$ siyah bantları gördükten sonra geri dönüyor. Ultrasonic sensörde engeli görünce elleri var elleri ile bidonları allyor.

Like the first camp, Kid.II.11 from the second camp emphasized on learning of sensors as:

Kid.II.11: Yes I learnt. How a robot is programmed, and put a light on it. I learnt how a light sensor works...

Kid.II.11: Evet öğrendim. Robotun nasıl programlandı̆̆ı nasıl robot yapmayı nasıl robotun ışık yapılır. Işılk sensörü nasıl çalışır onu öğrendim...

Correspondingly learning of the sensors was expressed on the evaluation forms from both camps.

Kid.I.15: We have measured the light tones with light sensor. We changed the direction when the ultrasonic sensor sees an obstacle.

Kid.I.15: Işık sensörü ile renk tonlarını ölçtük. Ultrasonik sensör ile engeli görünce yön değiştirdik. 
Kid.I.29: We have learned how to mount sound sensor and program from computer and start sound sensor when applause.

Kid.I.29: Robota ses sensörünü takıp bilgisayardan programlamayl, alkışlayınca ses sensörünü çalıştırmayı öğrendim.

Kid.II.07: I learnt that how our robot evaluates the sound, vision, and light sensors.

Kid.II.07: Robotumuzun ses, görme, ışık gibi sensörleri nasıl ölçtügün̈ü ögrendim.

During the camp, the children worked with four different sensors. As a result of this engagement, children had learnt how to use a sensor. As the children expressed, they learnt not only what is a sensor, but also they create logic how to use a sensor to solve a problem.

\subsection{Mechanic}

When they asked what they have learnt from the camp, one of the answers was learning of combining pieces. A Lego Mindstorms NXT set comes with approximately four hundred pieces and with a resource set the number of the pieces more than a thousand. With these building elements the children can create their own design. The children valued combining these pieces as a learning outcome of the camps. Eleven children at the first camp and five children at the second camp stated that they have learned combining the Lego pieces both in interviews and evaluation forms.

R: So, when you mention about learning, could you tell what you mean?

Kid.I.04: How to mount program that is building Legos.

R: Peki ögrendim derken neleri ögrendin bunları söyler misin.

Kid.I.04: Programlamayı takmayı mesela öyle işte. Yani Legoları birleştirmeyi.

$R:$ So, did you learn something from the camp?

Kid.II.17: Yes, I did.

$R:$ For example, what did you learn?

Kid.II.17: I learnt how to program. I learnt how to run and combine them.

R: Peki bir şeyler öğrendin mi sence bu süre içinde kampta. 
Kid.II.17: Öğrendim.

$R:$ Mesela neler ögrendin?

Kid.II.17: İște programlamayı öğrendim. Onları nasıl birleştireceğimi falan öğrendim çalıştırmayı öğrendim.

Similarly, the children expressed combining Lego pieces as a learning outcome in evaluation forms.

Kid.I.15: How to combine several materials and make robot and make it walk with passion...

Kid.I.15: Birçok malzemeyi birleştirip robot yapmayl, azimle robotu yürütmeyi...

Kid.II.09: I learnt how to combine the robot parts, sensors and how to put them.

Kid.II.09: Robotun parçalarını, sensörlerini birleștirmeyi, takmayı...

\subsection{Instructors' opinions about robotics}

The instructors think that the second camp has more positive effects on the robotic concept learning programming, mechanic, sensors etc. Like Instructor 2 stated the main reason for better learning outcome was fixed number of the children each group and appointment of an instructor to each group.

The children have learnt robotics better, in addition to robotics; they have learnt the concepts very well, because there was an instructor for four children. The instructors only care them and ask them one by one. All of them have learnt better, in addition, evaluation of the students was easy. (Instructor 2)

Çocuklar robotu daha iyi öğrendi, robotu artı konuları çok iyi öğrendiler çünkü eğitmene dört öğrenci düşüyor. Sadece onlarla ilgileniyorsun ve onlara tek tek sorabiliyorsun. Hepsi çok iyi öğrendi bide ayrıca öğrencileri değerlendirmekte kolay oldu (Ë̈itmen 2).

One of the instructors stated that after three days of challenging programming section, the learning stations was so easy and that affected children's motivation negatively.

After complex programming, passing to the science and mathematics concepts were easy. Because only "move" command was used, you know, how could I say, they backward, negatively transferred. It is like we block their speed. (Instructor 3) 
Zaten hani o kompleks programlardan sonra geçince o fen matematik müfredatina konularına kolay kaldl "move" komutunu kullaninca sadece orda hani çocuklar geriye nasıl denir olumsuz aktarma oldu. Hızların kestik gibi bir şey oldu (Ë̆itmen 3).

That could be interpreted as during the camp the children should be continuously challenged and their motivation should be kept high during the camp. One way to achieve that, request them to create more and more challenging programming activities even work on science and mathematics activities.

\subsection{Conclusion on robotics}

Robotics content knowledge (general robotics knowledge, programming, sensors, mechanics and interest in robotic) was an inevitable outcome for successful robotic activities. The most important outcome of both camps was that the children have learned programming. The children's and instructors' interviews and the researcher's observation proved that. Although, programming could be very challenging for that age children in classical programming environments such as basic or Pascal, NXT-G programming environment makes programming understandable for children. Even, the children could use nested loops at the end of the camp.

It is obvious that the programming section is inevitable part of a robotics training camp. At the first camp, programming was mixed with math and science activities for example the children had learned how to move the robots then they made circumference and pi activities. After that, they moved back and continued programming. However, first three days of the second camp focused only on programming, the children have learned just programming these three days than learning stations started.

Percentage of the children who stated that have learned the programming at the second camp was much higher than the first camp and the instructors also stated that the children learned programming better at the second camp. However, it was observed that some of the children had trouble to remember how to use some blocks at projects section in the second camp. During the learning stations (three days between programming and the project sections) the children made only simple programming mostly with move blocks. Therefore, they could forget how to use 
some of the advanced blocks. Moreover, firstly learning advanced programming in robots then moving to learning stations could also decrease the children's motivation towards learning stations.

The second important result under the robotics category is learning of the sensors. Like our sense organs, the sensors are crucial parts of the robots. Robots can interact with their environments through their sensors. During the camps, the children have chance work with sensors while building their robots. As a result of it, most of the children stated their learning about sensors.

Mechanic sub-category which is related to connecting Lego pieces to create functional part of a robot was also stated outcomes of both camps. During the camps, the children did not get direct/formal instructions about how they build their robots like programming or sensors. Programming and sensors concepts were firstly presented to them and then the children work on these concepts. However, the children build their robots according the manuals with the guidance of the instructors.

\subsection{Design principles for robotics}

While designing a robotics camp, robotics concepts should be carefully considered. Robotics concepts instructions could be design under four heading, general robotics knowledge, programming, sensors and mechanics.

General robotics knowledge could be presented at the beginning of the camp with interesting activities like videos, drawing pictures, role playing games and guiding questions. The children's attention toward the subjects could be directed like what a robot is? What the differences between a robot and a remote controlled toy are?

Programming, sensors and mechanic concepts could not be separated, that is these three subjects should be given to the children concurrently. When the children built their first robots, they want to operate them immediately however a robot could not operate without a program. In the same vein, a sensor could operate only when it is programmed. 
The content of the instruction at a robotics camps, should be organized from simple to complex and subsequent content should be integrated with former one. For example, firstly, the children should build their robots. Lego Mindstorms NXT's manual gives building instruction of a base robot. However, it is advised to start simpler base robot like in Appendix K. Later, they could build the design in the manual. Toward the end of the camp, the children should be encouraged to build their own design for their projects.

Similarly, the children should start programming with simple move command. Meanwhile, the sensors concept should be integrated to the instruction. During the programming and sensors instruction the children should have chance to practice what they have learned. In addition, they should be challenged with programming their robots for specific missions.

Three days (around 6 hours a day) instruction section is quite enough to introduce NXT Mindstorms sets and teach NXT-G programming environments with advanced panel and necessary practices. Therefore, while designing a robotics camp approximately 18 hour's should be reserved for fundamental robotics instruction section.

\subsection{Mathematics and science}

Suitable mathematics and science concepts were investigated by using robot sets at

both camps. Activities were prepared at the first camp and learning stations were prepared at the second camp for mathematics and science concepts.

As stated in the "diary of the first camp" section, activities in the camp were related to mathematics and science. First two activity sheets (Appendix F and G) were especially related to mathematics and their subjects were circumference, radius and pi. The third and fourth activities (Appendix $\mathrm{H}$ and I) were related to science concepts and their subjects were velocity and sound.

However, as explained in the "diary of the second camp" section mathematics and science concepts were investigated at learning stations between the fourth and sixth 
days of the second camp. Geometrical shapes, circumference-pi, gears, sound and velocity concepts were the subjects investigated at learning stations.

Table 4.7 shows the frequencies of mathematics and science related sub-categories from the interviews with children and camp evaluation forms from both camps.

Table 4.7

Mathematics and science

\begin{tabular}{llcccc}
\hline \multirow{2}{*}{ Category } & Sub-category & \multicolumn{2}{c}{ I. Camp } & \multicolumn{2}{c}{ II. Camp } \\
& & $\#$ & $\%$ & $\#$ & $\%$ \\
\hline \multirow{3}{*}{ Mathematics } & Math reinforced & 7 & 23.3 & 1 & 4.5 \\
& Interest in math & 2 & 6.7 & 2 & 9.1 \\
& Circumference - pi & 7 & 23.3 & 9 & 40.9 \\
& Geometrical shapes & - & - & 4 & 18.2 \\
\hline \multirow{3}{*}{ Science } & Science general & 10 & 33.3 & - & - \\
& Science reinforced & 4 & 13.3 & 2 & 9.1 \\
& Interest in science & 1 & 3.3 & 1 & 4.5 \\
& Gear & - & - & 8 & 36.4 \\
& Sound & - & - & 7 & 31.8 \\
& Velocity & - & - & 6 & 27.3 \\
\hline
\end{tabular}

\subsection{Mathematics}

Totally sixteen children from each camps expressed positive effects of the camps their mathematics knowledge. They stated that during the camp they have learned with fun, like the statement of Kid.I.25.

Kid.I.25: It has improved my mathematics. My math skill was not very good this year but because it was funny here I could have learned math.

Kid.I.25: Benim matematiğimi geliştirdi. Benim matematiğim pek iyi değildi. Bu sene. Ama burada ĕ̆lenceli olduğu için öğrenebildim matematiğimi. 
Seven of the children from the first camp and nine children from the second camp stated that they have learned circumference - radius subject at the camps.

$R:$ So, do you think that the camp was beneficial to you?

Kid.I.20: Yes. In my fifth class, my teacher had taught radius. In fact, I could not have understood some terms such as pi number. Here with XXX teacher I could have understood more.

R: Peki kampın sana faydası olduğunu düşünüyor musun?

Kid.I.20: Evet. Beşinci sınıfta ögretmenimiz yarıçapı anlatmıştı. Onun pi sayısını falan onları açıkçası anlamamıştım. Burada XXX abla ile beraber çözerken iyice şey oldu.

Kid.I.23: I had a problem with math. When we were calculating circumference of wheel, with using meters I have learned it so I have relaxed.

Kid.I.23: Matematikte bir sorunum vardl. Tekerlek çevresi hesaplamada metresini falan ölçtügüumüzde nasıl hesaplanacă̆ını öğrendim. Rahatladım o yüzden.

Kid.I.24: Yes. The ambient here is beautiful than the school. And if I compare with the school, here I have learned much than school such as science and math. For example, at calculating diameter, circumference and area topics, I tried to learn more and I believe that I learned.

Kid.I.24: Evet yani okuldan bir kere burası daha güzel yani buradaki ortam güzel okuldan ve okulla klyaslarsak yani okuldaki öğrendiğimden daha çok şey ögrendim burada fen olsun matematik olsun hesaplamalarda çap çevre alan hesaplamasında falan burada daha çok şey öğrenmeye çalıştım ve öğrendim de yani ben böyle inanıyorum.

Similarly, the children expressed their content knowledge about circumference - pi in the evaluation forms.

Kid.I.20: We have learned that in order to return a robot $180^{\circ}$, a motor should be stopped. Moreover, I have learned that in order to find the way a wheel goes we have to calculate circumference $x$ round number.

Kid.I.20: Bir robotun 180 derece dönmesi için bir motorun durmasının gerek olduğunu ögrendik. Bir de tekerin aldiğl yolu bulmak için çevre uzunluğu $x$ tur sayısı olduğunu öğrendim.

Kid.II.08: Generally, we learnt diameter, radius, and pi number too. 
Kid.II.08: Genel olarak çap ve yarıçap aynı zamanda pi sayısını... öğrendik.

Seven children from the first camp and one child from the second camp expressed that they have already known the some mathematics concepts but the camp reinforced their mathematics knowledge through activities.

Kid.I.29: At mathematics, in fact I had known but I have improved topics such as circumference etc. I had learned at fourth class but because it was not this year, I have improved.

Kid.I.29: Matematikte işte çevre işte onları gerçi biliyorum da biraz pekişti işte bu sene öğrenmediğimiz için daha geçmedik onlara dördüncü sınıfta öğrenmiştik daha da böyle pekişti.

Kid.I.03: ...We have made calculations with math. In those activity sheets, there were always calculations. We made them. From that point it was helpful to us. We could have both improved it and also had chance to repeat the things that we have learned at fifth class but not this year.

Kid.I.03: ...Matematikten hesap yaptık. Zaten o aktivite kâğtlarında sürekli hesap vardı. Onları yaptık. O açıdan bize yararlı oldu. Hem pekiştirme hem beşinci sınıfta öğrenip bu sene ögrenmediklerimizi bir genel tekrar yapmış olduk.

$R:$ Is there anything else that you have learnt?

Kid.II.20: I had chance to repeat science and math subjects.

R: Başka öğrendiğin bir şey var mı?

Kid.II.20: Başka öğrendiğim fen matematik konularını tekrar etmiş oldum.

Two children from each camp expressed that they have liked the mathematics at the camps.

R: You have seen and created equations, what do you think about them?

Kid.I.30: They were also good because they were mathematical that is here we both learned and had fun.

$R$ : You also learned, did these have role on learning?

Kid.I.30: Yes.

$R$ : You say yes, so if we have chance to repeat this camp...

Kid: I liked math but I have a teacher who makes me not to like math. 
R: Gördünüz, denklemler kurdunuz onlar hakkında ne düşünüyorsun?

Kid.I.30: Onlar da güzeldi çünkü bizim matematikle ilgili yani biz burada hem ĕglendik hem öğrendik

R: Hem öğrendiniz bunları ögrenmede faydası oldu mu?

Kid.I.30: Evet

R: Oldu diyorsun. Peki, biz bu kampı tekrar yapacak olsak...

Kid.I.30: Ben matematiği sevdim ama benim bir ögretmenim var matematiği sevdirmiyor

Kid.II.05: For example, I do not know, I am thinking and I know math I think. I loved it.

Kid.II.05: Mesela ne bileyim faydası olduğunu düşünüyorum ama matematiği biraz daha iyi biliyorum. Sevdim sanki.

One of the kids, who had forgotten writing his /her name on the evaluation form, stated that the activity had impressed him/her so much then his/her attitudes toward mathematics has changed.

Kid.I.UN: This activity affected me very much, and from now on I love mathematics and science lessons very much. Thanks.

Kid.I.UN: Bu etkinlik beni çok etkiledi bundan sonra matematik ve fen dersini çok seviyorum. Teşekürler.

Geometrical shapes were one of the learning stations at the second camp and it was not an activity at a first camp. Therefore, four children from only the second camp expressed that they have learnt geometrical shapes in the evaluation forms.

Kid.II.11: We learnt how to draw triangle, square, circle, and rectangle with robot.

Kid.II.11: Robotla üçgen kare çember dikdörtgen çizmeyi öğrendik.

Because both camps have some mathematics activities with robots, the children stated that their learning about related mathematics concepts. However, the most important point is some of the children stated that they liked mathematics at the camps. Therefore, mathematics instruction at a robotics camp should be prepared in a way that, the children will like not only robotics activities but also mathematics. 


\subsection{Science}

On the fourth day of the first camp, the instructor from science education department attended the camp and he make small oral quiz to decide the queue. Moreover, he gave information about velocity, displacement and time. Therefore, the children mentioned about the instructor and effects on their science content learning. Ten children from the first camp expressed that the camp had positive effects on their science knowledge.

$R:$ For instance, what kind of benefits did it have?

Kid.I.30: What kind of... A bit for the mathematics and then instructor XXX asked questions about science that is I think it was effective for mathematics and science.

\section{R: Mesela ne gibi faydaları oldu}

Kid.I.30: Ne gibi oldu matematikte biraz oldu sonra XXX abi fenle ilgili sorular sordu onunla yani matematikle fene etkili olmuştur diye düşünüyorum

Kid.I.24: ... as I told that I have learned lots of things about mathematics and science. I answered questions asked by instructor $X X X$ during the competitions and also there were some questions that I did not know and I learned their answers.

Kid.I.24: ...Dediğim gibi matematik ve fenle ilgili birçok şey öğrendim. XXX abinin yaptı̆̆ yarışmalarda da işte soruları cevapladım bazı bilmediğim sorularda vardı orada cevaplarını da ögrendim.

Four of the kids from the first camp and two kids from the second one stated that they had already known the science subjects they worked during the camp but they had chance to repeated that subjects, therefore they reinforced their science knowledge.

Kid.I.UN: We had known how to calculate velocity of a moving object but we had chance to repeat it.

Kid.I.UN: Bir hareketlinin süratini (hızını) hesaplamayı biliyorduk. Ama burada tekrar etmiş olduk...

$R:$ For example what kind of benefits did it have?

Kid.I.05: For instance, in fact we had learned circle and measurements of circle but we had forgotten it.

$R:$ Equations?

Kid.I.05: Velocity-time relations. 
R: Mesela ne gibi faydaları oldu

Kid.I.05: Mesela aslında öğrenmiş̧tik ama sonradan unuttum. Çember Çemberin ölçümleri denklemler onlar.

R: Denklemler?

Kid.I.05: Sürat zaman ilişkileri.

Kid.II.09: I am thinking. I am a person who does not like science and math. Here, I loved math and science more.

Kid.II.09: Düşünüyorum. Ben zaten matematik ve feni seven bir insan değilim. Burada Matematik ve Fen'i biraz daha fazla sevdim.

One kid from each camps stated that the camp changed his attitude toward science course.

$R$ : What benefits did it have?

Kid.I.9: Before here I did not like science and mathematics lessons because I did not know the topics... but now I love very much.

R: Ne gibi faydalar oldu.

Kid.I.09: Eskiden fen dersi ile matematik derslerini sevmiyordum. Bilemediğim yerler olduğu için... Ama artık çok seviyorum.

Gear, sound and velocity learning stations were science related learning stations at the second camp. Therefore the children mention what they had learnt from these stations. During the interviews no child mentioned a specific science concept, they reflected only in evaluation forms. Eight children stated learning of the gears subject.

Question: Today, what did you learn in the activity?

Kid.II.09: I learnt about gears, velocity of the engine (robot's), calculating the amount of the way that it takes according to the number of gears.

Soru: Bu gün etkinlikte neler öğrendiniz?

Kid:II.09: Dişlileri, motorun (robotun) hızını, dişli sayısına göre aldığı yolu v.b. şeyleri hesaplamayı öğrendim.

Seven children wrote that they have learnt sound subjects.

Kid.II.13: I learnt about intonations, sound wall, sound frequency, the difference of the cat and bear voice frequency whether lower or higher. 
Kid.II.13: Tonlamaları, ses duvarı, ses frekansını kedi ve ayının seslerinin frekansı yüksek mi düşük mü onları öğrendim.

Moreover, six children reflected the velocity subject but all of them did not give any details about this subject.

Kid.II.15: ... We have studied velocity subject with instructor XXX.

Kid.II.15: ...XXX ablada hız konusunu işledik

Science related learning outcomes of the camps are similar to the mathematics outcomes. Preparing such science activities that affect the children attitudes toward science is also important for science concepts in a robotics camp.

\subsection{Instructors' opinions about mathematics and science}

Circumference-pi learning station's instructor made self-criticism about the learning station. She stated that the children enjoyed station work and some of the children put into word heir enjoyment, however she complained about not enough usage of robots at the station.

I tried to mention the mystery of pi. You know, there were interested children some group says how much fun it; it is not the mathematics we learn at school. Because we could not use robots much, the children could not grasp it is a robot camp or not at that activity (Instructor 3).

İste pi sayısının gizeminden bahsetmeye çalıştım. Hani belki bazı guruplarda çok ilgili çocuklar vardı yine bunu dinleyen aaaaa ne kadar zevkliymiş işte okulda gördü̈̆̈̈̈müz matematik gibi değilmiş diyen var ama çok fazla robotu kullanmadı̆̆ımız için robot kampın olup olmadı̆̆ını o etkinlikte kavrayamadı (Eğitmen 3).

Another instructor stated that connection between mathematics and robotic activities should not be simple as calculation of circumference, the children should be challenged with complex problems and they should use their mathematics knowledge to overcome the problem. She also admitted that they had not been successful about using robotics in that way.

So it will fulfill mathematics when doing calculation. But it must be like "children now we going to do division, today we will divide the 
distance to the circumference of the tire at robot" not like that way. Some complex situation should be given them to chance to use their knowledge. We could not do that because our mind is limited. (Instructor 1)

Yani matematiği de karşılayacaktır hesap yaparken geliştirecektir. Ama şöyle olmalı "çocuklar şimdi bölme işlemi yapacağız bugün robotta yolu çevreyi tekerin çevresini böleceğiz. Bakın bölme işlemini kullanıyoruz” değil de çocuklara bildikleri bir şeyleri kullanmaları için kompleks bir şeyler verilmeli. Biz bunu yapamıyoruz çünkü bizimde aklımız sı̆̆ gerçekten (Ĕ̆itmen 1).

The instructors criticized their approach to combining science concepts and robotics at design phase. They stated that, they searched science curriculum for appropriate science concepts. After two robotics camps experience, like mathematics theme, the instructors think that instruction should not be direct instruction, a camp should provide complex situation and put children in it. Therefore, the children should use previous knowledge to solve the problem or situation. Moreover the camp should not abide by the school curriculum; the robots should give them something that not in the curriculum.

It was very limited, because we came from this education system. So, our vision so limited. I am doing like that; I am looking the subjects in the curriculum, what could be done, nothing. For example DNA in biology, is it related to the experiment, no I could not find. For example, circulation of blood, we think in this way, it moves on circulation of heart. According to us, the robot is just moving, we do not have anything else...(Instructor 2)

So, we had limited with curriculum, this robots should give something else ...(Instructor 1)

Çok sınırlıydı sonuçta bizde bu eğitim sisteminden geldik, yani bakış açımız o kadar dar ki alıyoruz ben böyle yapıyorum müfredatta konulara bakıyorum kazanımlarına bakıyorum ne yapılabilir elle tutulur bir şey yapılamaz. Biyoloji işte bakıyorum DNA işte deneyle hiçbir alakası var mı bulamıyorum. Mesela kan dolaşımı işte böyle düşünüyoruz kalp dolaşımının üzerinde gitsin bize göre robot sadece gidiyor başka bir şey yok kafamızda işte varda...(Eğitmen 2).

Yani biz müfredata kısıtl l kaldık ki bu robotlar başka bir şeyler versin çocuklara...(Ë̆itmen 1).

In the same way, Instructor 2 emphasized, encouragement of the discovery learning.

I think they find themselves such things. We should expect to discover some things. Yes, in this way, it remains like mold. The lesson is like mold. Let's measure the light with light sensor. Let's try this lesson we know. The problem is given and those subjects are inside the problem and the children use them while interpreting. (Instructor 2) 
Bence böyle şeyleri kendileri bulsun böyle şeyleri yapsinlar. Bir şeyleri keşfetmelerini beklemeliyiz. Ya evet yani bu böyle kallp şeklinde kalıyor. Ders kalıp kalıyor, orda böyle bir kalıp. Ha bırakalım onu, hadi bakalım ışık sensörü ışığın hadi şeyini ölçelim. Bu bir dersimiz bizim deneyelim de hani bir problem verilir problemin içinde geçsin onlar çocuk onları yorumlayarak kullansin. (Eğitmen 2)

\subsection{Conclusion about mathematics and science}

At the first camp, mathematics concepts were given with activity sheets and the activities were not separated from the robotics education. For example, the children had learnt "move" block, then they worked on circumference activity, after that they back to programming. However, at the second camp, they worked on mathematics concepts in the related learning stations after completing robotics and programming education.

At the end of the camp, the children stated that they have learnt or have been reinforced related mathematics concepts. Some children from both camp also stated that increase in their interest towards mathematics.

Both camps resulted with similar way at mathematics dimension, because circumference and pi concept was common at both camp, the children from both camp mentioned about those concepts. Geometrical shapes added to the second camp as a learning station, therefore, some of the children also mentioned about that concepts at interviews.

The instructors believed that mathematics concepts should not be given as instruction, some context should be prepared and the children should use their mathematics knowledge in that context. Therefore, mathematics at a robotics camp would be more meaningful.

Attendance of the instructor from science department added a dimension to the first camp. Although the children did not state specific science concept, the children stated the instructor and his effects.

There were three learning stations related to science at the second camp which are gears, sound and velocity stations. The children mentioned about these stations only in evaluation forms. When science and mathematics category is compared with 
robotics category, it is obvious that robotics contents were much more stated than science and mathematics. It shows that robotics were much more impressed the children. That could be the reason why the children mentioned robotics and did not mention about science during the interviews at the end of the camp.

\subsection{Design principles for mathematics and science}

Mathematics and science dimension of a robotics training camp also should be carefully designed. Mathematics and science concepts should not be given with direct instruction at a robotics camps. The children could learn these subjects at their schools. Robotics training camps should give chance to practice what they have learned at schools.

The robotics camps have potentials to affect children's attitudes toward mathematics and science in a positive way. Therefore, mathematics and science activities should be prepared in a way that the children's should have chance to like mathematics and science.

As the instructors emphasized that some complex problems like real life should be prepared and the children should use their mathematics and science knowledge to solve that complex problem by using robots. Therefore, mathematics and science concepts at a robotics camps would be more meaningful.

At least one science instructor should attend to a robotic camp; therefore, that instructor can encourage and manage discussion about science concepts. For example, the fastest robot competition could be arranged. Therefore, like the instructors stated the children would be in a complex situation, while they design their robots, they should consider such as gears and radius of the tires. After the competition, the science instructor could make discussion about effects of gears and radius of the tires on velocity of a robot.

\subsection{Social skills}

The children worked in teams during the camps. It was observed that children worked as a group to be successful. Especially in competition or tournament, their collaboration and enthusiasm for being winner can easily be observed. Specialization 
on a task also observed in some of the groups. That is, one group member was responsible for programming and wrote the program on the computer, another one was responsible for combining pieces etc.

Moreover, they have eaten their meal together, the boys played football during the lunch break, and the girls played jumping rope. Sometimes, they played altogether at the end of the days.

At the beginning of both camps, the children were informed just the rules of the camps which were mainly focused on being polite to the instructors and group mates. Social skills expectations or any other social behaviors expectations were not announced to the children. As a result of being social environments, social skills category emerged as learning outcomes of the camps especially from the first camp. Table 4.8 presents emerged social skills category and its sub-categories from analysis of interviews and evaluation forms.

Table 4.8

Social skills

\begin{tabular}{llcccc}
\hline \multirow{2}{*}{ Category } & Sub-category & \multicolumn{2}{c}{ I. Camp } & \multicolumn{2}{c}{ II. Camp } \\
& & $\#$ & $\%$ & $\#$ & $\%$ \\
\hline \multirow{3}{*}{ Social Skills } & Social skills general & 13 & 43.3 & 2 & 9.1 \\
& Group work & 2 & 6.7 & - & - \\
& Lose - win case & 3 & 10.0 & - & - \\
& Low shyness & 1 & 3.3 & - & - \\
& Meal in community & 1 & 3.3 & - & - \\
\hline
\end{tabular}

The children were together during the camp hours and they worked as team during the camps. They did all activities together. Therefore, thirteen children from the first camp stated they have learned some social skills at the camp. Kid.I.25 stated her social learning as: 
Question: Generally, can you evaluate this activity? (Missing points, your suggestions and the things affected you positively or negatively)

Kid.I.25: Generally, in fact we even learned how to speak in this camp. We know how to speak but we learned how to speak well and polite.

Soru: Genel olarak bu günkü etkinliği değerlendir misiniz? (Eksik olan noktalar, önrileriniz, yaşadı̆̆ınız size etkileyen olumlu yada olumsuz olaylar)

Kid.I.25: Genel olarak bu kampta konuşmayı dahi ögrendik aslında konuşmayı biliyoruz ama daha iyi ve kibar konuşmayı öğrendik ...

R: What else did you learn?

Kid.I.25: I learned how to cooperate. I have learned how to get along with my friends. I learned that the robot is not so hard thing.

$R:$ Başka neler öğrendin.

Kid.I.25: Yardımlaşmayı öğrendim. Arkadaşlarım ile iyi geçinmeyi öğrendim. Robotun zor bir şey olmadığını öğrendim.

During camps the instructors encouraged the children to think they are a member of a group and they should work together and solve the problems together. Group issue will be reported later in this chapter however, as a social skill, two children stated that they have learned group working at the camp.

$R:$ What else did you learn during the camp?

Kid.I.30: What else I learned that how to work as group...

Peki başka neler öğrendin kampta

Kid.I.30: Başka neler öğrendim grupça çalışmayı sonra nasıl desem...

Kid.I.28, bulleted what he had learnt from the camp in the evaluation form and two of them were related with social skills.

\section{Kid.I.28: Cooperation \\ How to place arm to robot and program. \\ Trust, friendship.}

\section{Kid.I.28: Yardımlaşmayı \\ Robota kol takıp programlamayl \\ Güven. Arkadaşlık}

At design phase of the camp first camp, competitions were added to increase children's motivation toward what they were making. Competition will be examined 
with a detail in this chapter, but as a side effect of competition, three children stated they have learned winning and losing in the camp.

Kid.I.16: ... that is here we have learned win and lose much better...

Kid 16: ... yani kazanmakla kaybetmeyi daha da çok öğrendik yani burada...

During the interviews two children mentioned two unpredicted positive effects of the camp. Kid.I.01 mentioned about decrease of his shyness when talking with teachers and Kid.I.12 mentioned etiquette when eating meal in community.

Kid.I.01: Speaking with my teacher at school. For instance, I was ashamed while talking to my teacher. I came here and talked with our leaders here without shame. I went to my school and talked with my teachers too.

Kid.I.01: Okulda öğretmenimle konuşma. Mesela önce utaniyordum ögrretmenimle konuşmaya. İşta buraya geldim. Ablalarla falanda utanmadan konuştum. Okula da gittim öğretmenlerimle konuştum.

$R$ : Do you think that the camp was helpful.

Kid.I.12: Yes, yes. Enormously. First of all I was very hungry when I was eating meals. I put in to my mouth two of them and people warned me to be slow. As a result of these warnings, my manners became well. I can eat slowly even I am very hungry. Apart from this I learnt how to eat beside the other people with you much more belter. I learnt how to eat together.

R: Faydası olduğunu düşünüyor musun kampın.

Kid.I.12: Hıl hıl. Fazlasıyla. Bir kere mesela yemek yerken çok aç oluyorum. Allyorum hemen atıyorum iki tane azıma biraz yavaş ye lan diyorlar. Isşte öyle diye diye terbiyem biraz daha düzeldi. Çok acıksam bile daha yavaş yiyebiliyorum. Mesela. Onun dışında sizin yanınızda herkesin yanında yemek yenilebileceğini daha iyi bastırarak ögrendim. Hep birlikte.

The children were together from 8:40 to 15:00 and they worked as team during the camp. They did all activities together. However, unlike the first camp, only two children mentioned about learning of some social skills.

$R:$ Do you think that the camp was beneficial to you?

Kid.II.22: Yes.

$R$ : For example? 
Kid.II.22: At least I learnt how to work in group environment. I usually work as individual. I developed my group working skills. Moreover, my interest on it became higher.

R: Peki sana faydası olduğunu düşünüyor musun kampın?

Kid.II.22: Evet.

R: Mesela?

Kid.II.22: Yani ne biliyim böyle en azından bi grup ortamında çalışmaya. Ben genelde hep bireysel çallşlyordum. Hem grup ortaminda çallşmak şeyim gelişsti. Hem de böyle merakım daha çok arttı.

It is observed that, the working area of the first camp was much noisier, more crowded and messier than the second camps. In the first camp, the children can freely walk around and visited to the other groups. However, second camp was much more structured and orderly.

\subsection{Instructors' opinions about social skills}

One of the instructors also observed that the second camp was more orderly than the first camp and she was happy about the second camp working area.

I remember the other project (the first camp), there was always someone in the middle were walking constantly. Especially the station (the second camp), I'm looking for a class, I am at the corner, everyone is working. I said, oh God it is something so nice, super... (Instructor 1)

Ben diğer projeyi hatırllyorum (birinci kamp), sürekli dolaşıyorlardı sürekli ortada birileri vardı. Hele istasyonda (ikinci kamp) ben şöyle sınıfa bir bakıyorum en köşedeyim ya bide, herkes harll harıl çalışlyor. Allah'ım ne güzel süper bir şey falan diyordum... (Eğitmen 1)

During the interview, one of the instructors stated that one of the kid's behavior change about sharing robot.

Kid.II.05 especially when he took over, he was mumping. But when he came to my group, he put one piece and said to Kid.II.15 take it and put it. Whether, he behave like that because of my existence or he gained like that behavior.( Instructor 1)

Kid.II.05 özellikle elinden alınca da somurtuyordu ama sonra Kid.II.05 benim guruba geldi ya, geldi bir parçayı taktı sonra hadi bunu da sen tak Kid.II.15 dedi .Ya ben ordayım benim huyumu biliyor diye ya da gerçekten böyle bir kazanım elde etti.( Eğitmen 1) 
Moreover, one of the instructors gave quotation of one of the kid's statement about learning of group work.

One of the kids, talkative one, mentioned that he likes to work individually, he used to like work individually but he learnt at least group work at the camp. (Instructor 2)

Çocuklarımızdan biri bundan bahsetti bende bireysel çalıșmayı severim, çokta konuşkan, bende bireysel çalışmaktan hoşlanırdım ama burada en azından gurup çalışmasını öğrendim dedi.( Ĕ̈itmen 2)

\subsection{Conclusions about social skills}

The first camp social skills themes were much richer than the second camp's theme. Number of the group mates, number of the children at camp, being an instructor at each group and competition could be the reasons for the difference.

The first camp was more crowded than the second camp and the groups also. Therefore the children should have richer social environments at the first camp.

At the first camp, the number of the instructors was limited. Although it caused classroom management problem, the children could work more freely. They could visit the other groups and chat with them. However at the second camp, each group has an instructor, therefore the instructors could interfere any unwanted situation on time. Therefore, the children could work much more noiseless but less social environments.

Moreover, some of the children from the first camp mentioned that they have learned losing-winning case. At the second camp, competition was kept at minimum level; therefore the children could not find any chance to learn losing-winning case at the second camp.

As a sum, social outcome of a camp can be adjusted with these variables. Peer learning or more social outcome can be encouraged with less involved instructors but in less managed environment. 


\subsection{Design principles for social skills}

In group and between groups social interaction should be encouraged in a robotic training camp. Implementing cooperative learning and small group work strategies could enhance in group interaction.

Between groups interaction could be enhanced borrowing Lego pieces, sharing information or arranging competition between the groups. Moreover, playing physical games at breaks and eating meals together will also strengthen between group interactions.

\subsubsection{Evaluation of the camps' components}

Secondly, to answer the first sub question how the instruction should be structured, the researcher has taken children's opinions about the camp's components. Mathematics and science activities were implemented by activity sheets at the first camp, therefore the children asked to evaluate the activity sheets during interviews. Activity sheets were not used at the second camp, mathematics and science concepts were studied at learning stations. Therefore, the researcher changed the activity sheets question as evaluation of the camp components for the second camp interviews (See Appendix A). The children from the first camp evaluated only the activity sheets that used at the first camp and the children from the second camp evaluated the components of the second camp which are programming section, learning stations and project work.

\subsection{Evaluation of the first camp's component}

The whole curriculum of the first camp was composed of activities. These activities combine STEM concepts and robotics. That is the children used their mathematics and science knowledge with robots when working on these activities. As reported before, four activity sheets were prepared and used during the first week of the camp (See diary of the first camp). These activity sheets were the bridge between STEM concepts and robotics. During the interviews the children were asked to evaluate used activity sheets, Table 4.9 presents children's opinions about used activity sheets at the first camp. 
Table 4.9

Evaluation of activity sheets

\begin{tabular}{llcc}
\hline \multirow{2}{*}{ Category } & Sub-category & \multicolumn{2}{c}{ I. Camp } \\
& Math related & $\#$ & $\%$ \\
\hline \multirow{2}{*}{ Activity Sheets } & Learned new things & 11 & 36.7 \\
& Learned better & 6 & 20.0 \\
& Note to remember & 3 & 10.0 \\
& Like quiz & 5 & 16.7 \\
& Hard & 4 & 13.3 \\
& Boring & 2 & 6.7 \\
& & 2 & 6.7 \\
\hline
\end{tabular}

Eleven children stated that used activity sheets at the first camps were related to the mathematics.

R: We had distributed worksheets to you. What do you think about them?

Kid.I.22: They were helpful for mathematics. In that point they are useful for math. For example, some of my friends had forgotten some concepts such as computing the circumference of circle. When they were distributed, we had chance to repeat and we learnt. For instance, we had learnt how to use those robots, and how much will the wheel go, and how many times will wheel turn to go one meter. You gave us big wheel and it was helpful in these concepts.

R: Biz size çalışma kâğıtları dağıtmıştık. Onlar hakkında neler düşünüyorsunuz. Kid.I.22: Işste O matematikte işimize yartyor. Tam o noktada matematikte işimize yarıyor. Mesela bazı arkadaşlarımı şeyleri falan unutmuştu. Çemberin çevresini hesaplamayı. Burada o kâğttlar gelince falan tekrar ettik ve ögrendik. Mesela o robotları nasıl kullanacă̆ımızı falan öğrendik. Tekerlek ne kadar gidecek mesela. Bir metreyi tekerlek kaç turda dönecek mesela. Büyük tekerlek verdiniz bizlere. Öyle şeylerde faydalı oldu bize. 
According to the subject of the activity sheets, the children said that sometimes they learned the new things, sometimes they reviewed what they have learned before. Six children mentioned they have learned new things from activity sheets.

$R:$ In which activity sheets involve circumference of the circle and velocity?

Kid.I.15: When we had learnt the circumference of the circle first time, we did not know it. It was hard to learn it. We have repeated here and I know it well anymore.

$R$ : So, these activity sheets are kind of repeating or they had new things for you?

Kid.I.15: Both of them, I repeated some topics and also learnt new topics.

R: Hani aktivite kağıtlarındaki işlediğimiz konular var ya işte çemberin çapı hız konusu.

Kid.I.15: Çember çapını daha önce ilk öğrendiğimizde hiç bilmiyorduk. Ögrenirken zorlanmıştık. Burada tekrarladık. Artık biliyorum.

R: Yani bu aktivite kağıtları biraz, tekrar mı oldu yoksa yeni bir şeyler mi ögretti.

Kid.I.15: Hem tekrar hem de yeni bir şeyler öğrendim.

Moreover, four children mentioned they have reviewed their previous knowledge with the activity sheets.

R: We had prepared activity sheets for you. What do you think about them?

Kid.I.14: They were very useful in fact. We had chance to repeat things both we had learnt last year and this year. Normally, I do not think that there is no one opening the 4th year book and checking what learnt before.

R: Bir de aktivite kâğıtları hazırlamıştık hatırlıyorsan. Onlar hakkında neler düşünüyorsun.

Kid.I.14: Onlar aslında çok iyi oldu. Hem geçen senelerdeki yaptı̆̆ımız şeyleri hem de bu sene yaptığımız şeyleri tekrarlama firsatı bulduk. Normalde açıp da dördüncü sınıf kitabını ben ne yapmışım diye bakan yoktur sanırım.

Like Kid.I.16 expressed, three children stated that they learned better while engaging the activity sheets.

$R:$ So, are they beneficial for your school lessons?

Kid.I.16: They are enormously beneficial. In school we usually, just read and pass. We do not go over it carefully. But here, we go over them carefully and understand them better.

R: Peki onların faydası oluyor mu okuldaki derslerine 
Kid.I.16: Acayip çok faydası oluyor. Mesela okulda hemen okuyup geçiyoruz. O kadar çok üstünde kalmıyoruz. Ama burada yani üstünde çok kallyoruz. Iyice anllyoruz.

Children should make calculations and fill the blanks on the activity sheets with the results of these calculations. Later, they used these results to make their programs. Five of the children emphasize that kind of usage of activity sheets.

$R:$ What do you think of those sheets?

Kid.I.19: Those sheets were very good for us. They were telling us how to set up from where they were coming and they should go. It was easier for us to write them and then pass them to the computer. Our knowledge was rising while writing on it.

R: $O$ kâğıtlar hakkında neler düşünüyorsun.

Kid.I.19: O kâğıtlar bence verilmesi daha iyi olmuştu. Böyle gideceği bölgeden duracă̆ bölgeye kadar hesaplanması. Oraya yazıp bilgisayara geçirmemiz daha kolay oluyordu. Orada bilgilerimiz biraz daha çoğalıyordu.

Two of the children likened the activity sheets to quiz in the school and two of them stated that sometimes the activity sheets were hard.

R: How were those sheets? Let's start with them, were they good or bad?

Kid.I.06: Some parts on them were challenging. We had learnt some concepts such as way divide time etc. very long ago so it was hard and you helped us. It was good.

R: O kağıtlar nasıldı iyi miydi kötü müydü önce ordan girelim.

Kid.I.06: Bazı yerleri zorlayıcıydı. Şey eskiden öğrendiğimiz için yol bölü zaman falanı o yüzden biraz zorlandık sizler yardım ettiniz. Güzeldi.

Kid 11 stated he prefer working with robots to the activity sheets because, he find them a bit boring.

R: Do they have missing parts? Is doing them funny?

Kid.I.11: They were a bit boring for me. Having time with dealing robot was funnier for me.

R: Bunların eksik olan yerleri var mı? Onları yapmak eğlenceli mi?

Kid 11: Ya biraz sıkıyordu beni. Robota uğraşıp bir şeyler yapmak daha zevkli geliyordu.

\subsection{Evaluation of the second camp's components}

Instructional structure of the second camp was a bit different from the first one. The second camp consisted of three parts which were programming section, learning 
stations section and projects section. Therefore the children were asked to evaluate these sections of the camp. Table 4.10 shows children's opinions about the second camp's components.

Table 4.10

Evaluation of the second camps' components

\begin{tabular}{|c|c|c|c|}
\hline \multirow{2}{*}{ Category } & \multirow{2}{*}{ Sub-category } & \multicolumn{2}{|c|}{ II. Camp } \\
\hline & & $\#$ & $\%$ \\
\hline \multirow{3}{*}{$\begin{array}{l}\text { Programming } \\
\text { Section }\end{array}$} & Good & 4 & 18.2 \\
\hline & Loaded & 7 & 31.8 \\
\hline & Challenging & 5 & 22.7 \\
\hline \multirow{4}{*}{$\begin{array}{l}\text { Learning Stations } \\
\text { Section }\end{array}$} & Enjoyable & 8 & 36.4 \\
\hline & Familiar subject & 9 & 40.9 \\
\hline & Learned new things & 3 & 13.6 \\
\hline & Confusing & 1 & 4.5 \\
\hline \multirow{2}{*}{ Projects Section } & Good & 9 & 40.9 \\
\hline & Enjoyable & 5 & 22.7 \\
\hline
\end{tabular}

\subsection{Programming section}

The first three days of the second camp was the programming section. Without any considerations about science and mathematics concepts, the children combined the basic robot in the manual and then the programming blocks were explained them by a projection. After that, they asked to programs their robot for a given purpose such as following a black line or reaction to an object in specified distance.

It was observed that, the children were quite successful at programming of the robots. The children could use even "nested loop" in their programs. Their performance so astonished the researcher, he noted that;

At the programming part I did not tell so easy things. I even told about "Wire". In my opinion, kids take how much it is given to them, if they are curios. 
Programlama da hiç de basit şeyler yaptırmadım. "Wire” bile anlattım. Bence çocuklar ne kadar verilirse o kadarını alıyorlar, yeter ki istekli olsunlar (Researcher).

Four of the children stated that the first three days was pretty good.

Kid.II.02: First three days were very good. I learnt lots of things about robots.

$R$ : So, you were not bored in this process.

Kid.II.02: No.

Kid.II.02: İlk üç gün çok iyi idi. Robotlar hakkında çok şeyler öğrendim...

$R$ : Sıkılmadın yani bu süreçte.

Kid.II.02: Hayır.

However, seven of the children stated that the programming section was loaded for them.

Kid.II.08: Programming was good at the beginning. However, it was confusing because we learnt consecutively.

Kid.II.08: Programlama ilk olarak güzeldi. Ama ard arda öğrendiğimiz için kafa karıştırıyordu.

Kid.II.21: Actually, it was not so hard. But dealing with too much programming was boring.

Kid.II.21: Aslında şey çok da zor değildi de. Şey çok fazla olunca sıktı o biraz.

Similarly, when the advanced programming blocks explained (the third day)

Kid.II.15 reflected his boredom to evaluation forms.

Question: As general could you evaluate the today's activity? (Missing points, suggestions, and things affected you positively or negatively)

Kid.II.15: Today, we began working on a different place of the mindstorms program. It was different than previous ones and also it was complicated and hard. We were bored. The reason for that is doing programming continuously.

Soru: Genel olarak bugünkü etkinliği değerlendirir misiniz?(Eksik olan noktalar, önerileriniz, yaşadığınız sizi etkileyen olumlu ya da olumsuz olaylar)

Kid.II.15: Bugün ise yine mindstorms programında farkll bir yere girip orada çalışmaya başladık. Ama bu diğerleri gibi değil daha karışık ve zordu. Biraz sıkıldık. Onun nedeni ise sürekli program yapmamızd.

Five kids stated that programming section was challenging for them at the first but later they got used to it. 
Kid.II.01: First three days were hard because I did not know the subject well but on the third day I got used to it.

Kid.II.01: Ya ilk üç gün yani bilmediğim için biraz zordu deyim sonrada iyice alıştım o üçüncü günde.

Overall, the programming section of the second camp was a bit challenging for the children because all of the children had not written program before. However the children had learnt how to program their robots impressively faster and they could use even nested loop within three days programming instruction with NXT-G environment.

\subsection{Learning stations}

Some mathematics and science concepts were examined at the learning stations with the help of the robots between the $4^{\text {th }}$ and $6^{\text {th }}$ days of the camp. Eight of the children stated that the learning stations were enjoyable.

R: You had moved around each table one by one. When you think those works one by one.

Kid.II.04: That is good. They were the works that I liked much.

$R$ : Why were those parts that you loved most?

Kid.II.04: I learnt different things on each one. I moved from around other teachers. They taught very funny.

R: Her masayı tek tek dolaştınız ya. O çalışmaları tek tek düşünecek olursan.

Kid.II.04: $O$ çok iyi. Onlar en sevdiğim çalışmalar zaten.

R: Peki neden en çok sevdiğin kısımdı?

Kid.II.04: Her ayrı ayrı şeyler öğrendim mesela. Başka öğretmenleri gezdim. Onlar çok eğlenceli öğretti.

Nine of the children expressed that they have already familiar some of the learning stations' subjects; therefore they a bit bored at that learning stations.

Kid.II.01: For example, in other three days, we were repeating the thing that I knew before so I was bored.

Kid.II.01: mesela sonrada diğer üç günde istasyon çalışmasında bazı şeyleri biliyordum bildiğim şeyler tekrar etmek bana sıkıcı geliyor orada biraz sıkıldım.

Kid.II.21: I bored at thing. For example, it was A, B, C and coming and going.

$R$ : Velocity subject.

Kid.II.21: I bored at that. Actually I bored a bit because I had known that. 
Kid.II.21: Şeyde sıkıldım. Mesela hani A B C diyordu bi gidiyo bi geliyo.

bi gidiyo bi geliyo.

R: Hoz konusu.

Kid.II.21: Onda biraz sıkıldım. Aslında şey yani bildiğim için sıkıldım biraz.

Tree of the children mentioned that they have learnt new things from each station.

$R:$ So, do you think that it was useful?

Kid.II.03: Yes. I mean I learnt different things in each group.

R: Peki faydası olduğunu düşünüyor musun?

Ki.II. 03: Evet. Yani çünkü orada her grupta yeni bir şey öğrendim.

Lastly Kid.II.12 complained that she had confused, because each station had different concept and it was hard to comprehend them for her.

Kid.II.12: Yes, you go there and you are told something different, and you go there and told different and your mind becomes things...

$R:$ Get confused?

Kid.II.12: Yes you cannot gather all of them.

R: Did you have difficulty or was it hard for you?

Kid.II.12: It was a bit hard for me to understand.

Kid.II.12: Evet oraya gidiyorsun başka şey anlattyor, oraya gidiyorsun başka şey anlatıyor insanın kafast şey oluyordu.

R: Kafası karışlyordu.

Kid.II.12: Evet hepsini bir araya toplayamiyorsun.

$R$ : Orada peki zorlandın mi sana zor mu geldi?

Kid.II.12: Biraz anlamam zor geldi.

The learning stations were mostly enjoyable. The children worked at learning stations with fun. However, some of the children stated that they had already familiar to the subject of some learning stations. The camp curriculum was designed for $6^{\text {th }}$ grade students but there were children from $7^{\text {th }}$ and $8^{\text {th }}$ grades. Therefore, constructing camp with mixed grades children negatively affected the learning stations activities.

\subsection{Projects}

The children worked on their robotic projects between the 7th and 9th days of the second camp. Each group has different robotic projects for different daily life 
problems. There was not any negative statement about the projects section. Fourteen children expressed that projects section was pretty good and enjoyable.

Kid.II.22: The most positive thing that I liked most? We had Project works and the most important thing that we designed them an even with our designs we could have achieved it and this is something very proud. At you say yourself that I designed this and it what I wanted. Something very proud.

Kid.II.22: Hoşuma giden en olumlu şey? Ya bu proje çalışmalarımız oldu hani özellikle de tasarımımızın kendimize özgü olması ve öyle olduğu halde de başarmamı hani çok gurur verici bi şey ve çok hani zevkli sonuçta yani. Diyorsun ki bunu ben tasarladım kendi kafama göre ve oldu. Çok gurur verici bi şey.

Kid.II.19: Project part was more difficult than others but also it was the most funny part for me.

Kid.II.19: Proje kısmı diğerlerine göre daha zordu ama en zevklisiydi bence.

One of the important outcomes of the study is projects section of the second camp was most enjoyed part of the camp. There was any negative statement about the projects section of the camp.

\subsection{Instructors' opinions about camps components}

The main difference between the two camps was the replacement of the activity sheets with learning stations. Instructors emphasized that the learning stations was better than the activity sheets. Instructor 1 stated that:

I liked the learning stations application very much, I think it could be improved (Instructor 1).

Istasyon uygulamasını çok beğendim geliştirilebilir diye düşünüyorum (Eğitmen 1).

Moreover, Instructor 2 emphasized management advantages of learning station approaches.

The learning stations were very successful in my opinion, because every teacher had children to be responsible for...Or when I saw someone, I know that which instructor was responsible for. Other way, they become very free (Instructor 2). 
Özellikle istasyonlar çok başarlliydı bence, çünkü her bir öğretmenin sorumlu olduğu öğrenciler vardl... Ya da birisini gördü̈̆̈̈̈mde hangi ablanın ya da abinin sorumluluğunda biliyordum. Diğerleri çok serbest oluyorlar (Ë̆itmen 2).

However, during learning stations the children worked on mainly mathematics and science concept and little programming. When they started to their projects, it was observed that some of the children were not applied what they have learned at programming section. One of the instructors also stated that same situation in her group.

After the first design, when they started to their projects, they would start to programming, I said come on do it, there were some children stated that they have already forgot programming (Instructor 3).

Şeyden sonra hani o projeye başladiklarında hani ilk tasarlamaları bitti programlamaya geçecekler diyorum hadi yapsana programlamay unuttum falan diyen oldu (Ĕ̈itmen 3).

One of the hardest issues of preparing instructional robotic camp was finding suitable science or mathematics concepts and expressing these concepts using Lego Mindstorms. Although all of the instructors find learning stations successful, some of the instructors complained that they could not use robots so much in their stations.

You know, there were interested children some group says how much fun it; it is not the mathematics we learn at school. Because we could not use robots much, the children could not grasp it is a robot camp or not at that activity (Instructor 3 ).

Hani belki bazı guruplarda çok ilgili çocuklar vardı yine bunu dinleyen "aaaaa ne kadar zevkliymiş işte okulda gördüğümüz matematik gibi değilmiş" diyen var ama çok fazla robotu kullanmadığımız için robot kampın olup olmadığını o etkinlikte kavrayamadı (Ĕ̈itmen 3).

I said science and technology and sound, like the Instructor 3 stated, how much robot was used my station is discussable. In addition, "theramin" used to change frequency of sound. Maybe, the interesting thing was not the robot. Sonic barriers were more interesting for them. I think they clearly understood that sound is a vibration and these vibrations are real. That is, they could be intensified to be a barrier. I think they clearly understood that (Instructor 1).

Fen teknolojisi birde ses diyordum da Eğitmen 3'nin dediği gibi hani benim konumda da ne kadar robot vardı bu tartışılır? Bide işte diğer "teramin" aleti 
frekansta ses değiştiriyorsunuz. Robot yani çocukların dikkatini çeken kısım belki de o değildi. Daha çok şeyler dikkatini çekiyordu. Ses duvarı olayı çok dikkatlerini çekti hepsinin oradan da ben şeyi çok iyi anladıklarını düşünüyorum. Artık ses bir titreşimdir ve bu titreşimler gerçektir. Yani bir duvar oluşturabilecek kadar yoğunlaştıran bir şeydir. Bunu çok iyi anladıklarını düşünüyorum (Eğitmen 1).

\subsection{Conclusions about evaluation of the camps' components}

It is important to evaluate the components of both camps to reach better camp curriculum. After the first camp, the instructors decided to try learning station approach for the second camp.

When the activity sheets from the first camp, programing, learning stations and projects section from the second camp compared; projects section of the camps was the most enjoyable and most liked part of the overall camps. Projects sections were last parts of both camps and while working on the projects, the children had chance to design their own robots and use what they learned during the programming section. They had to solve design and programming problems of their robots. While they working on their project, they worked more freely than the other sections of the camp. If there is not any science and mathematics consideration, after the basics of Mindstorms NXT and programming, the rest of the camp could be arranged one day or half day long mini projects. Alternatively, science and mathematics mini projects could be prepared.

According to instructors using learning station approach instead of activity sheet is better approach. Learning stations make easier classroom managements and it was also more productive usage of the resources. With limited resources such as limited extra sensors (accelerometer, temperature, force sensors etc.) the children could work on different applications of robotics at different learning stations.

\subsection{Design principles for camps' components}

While designing robotics camp curriculum, projects parts should be emphasized, if it is possible whole camps curriculum should made of small projects. Because the projects section is where the children use what they have learnt and the children should encouraged to application of the knowledge. 
STEM related concepts should be studied at learning stations, because learning stations were better than using activity sheets. Activity sheets also could be used at learning stations. Moreover, at learning stations, robots should be used actively, that is the children should have chance programming more than just using "move" block.

\subsubsection{Career}

During the interviews some of the children, especially girls, stated their interest toward technology, computing and engineering career. Table 4.11 presents frequencies of the children from both camps who stated their interest about robotics career.

Table 4.11

Career

\begin{tabular}{lcccc}
\hline \multirow{2}{*}{ Category } & \multicolumn{2}{c}{ I. Camp } & \multicolumn{2}{c}{ II. Camp } \\
& $\#$ & $\%$ & $\#$ & $\%$ \\
\hline Career & 3 & 10 & 4 & 18.2 \\
\hline
\end{tabular}

Three of the children from the first camp expressed that, they started to think career about computing and robotics. Kid.I.13 (a girl) stated that:

$R$ : Does robot camp have any benefits for you?

Kid.I.13: Yes.

$R:$ What are the benefits of robot camp?

Kid.I.13: For example, if I'll be interested in robot, I can continue working on robot professionally

R: Peki sana faydası olduğunu düşünüyor musun bu kampın.

Kid.I.13: Evet.

$R:$ Ne gibi faydalart var mesela.

Kid.I.13: Mesela büyüyünce robot ĕger ilgim olursa belki bu meslĕge yönelebilirim.

From the second camp, four children ( 3 of them was girl) mentioned that the camp has effect on their attitudes towards the technology and engineering. Kid.II.06 stated that:

R: Do you think that the camp will be useful for you? 
Kid.II.06: Yes, I do. Maybe my opinions could change and later it could be helpful during my carrier. Maybe when I grow up, could be useful in my school life.

R: Sana faydası olacağını düşünï̈yor musun kampın?

Kid.II.06: Düşünüyorum. Belki fikirlerim değişebilir yarın meslek hayatımda yardımcı olabilir. Belki büyüyünce okul hayatımda yardımcı olabilir.

\subsection{Conclusions about Career}

During design phase of the camps, career effect of a robotics camp could not be considered and the researcher also did not investigate the subject. The children stated their career intention when they taking about benefits of the camps. Although without direct question about their career intention three children from the first camp and four children from the second camp stated their career intention. Therefore, the real effect of robotics camps on the children career decision might be greater.

\subsection{Design principles for career}

It seems that, robotics camp has effects on participants' interest towards technology and their engineering career. If one of the aims of the camp is to increase children's interest toward technology, computing and engineering, in addition to the robotics activities, career choices could be emphasized. In addition, a guest who has robotics career could be invited to discuss career options with children. Moreover, female guest advised because she also will be a role model for the girls.

\subsubsection{Group issues}

The second sub-question is what the group, gender and individual differences issues are? At the first camp the groups were not strictly structured, when the students had problems with his/her group; they can change their group with the approval of new group members. Therefore, some children had chance to work with different groups with different characteristics. However, at the second camp groups were fixed that is the groups did not change except little adjustment done by instructors.

The children's opinions about group size, group members' gender, group problems and solutions for the group problems were taken. Table 4.12 shows the frequencies 
of the sub categories of group issues from the interviews and camp evaluation forms from both camps.

Table 4.12

Group issues

\begin{tabular}{llcccc}
\hline \multirow{2}{*}{ Category } & Sub-category & \multicolumn{2}{c}{ I. Camp } & \multicolumn{2}{c}{ II. Camp } \\
& & $\#$ & $\%$ & $\#$ & $\%$ \\
\hline \multirow{3}{*}{ Group size } & 3 members & 12 & 40.0 & 6 & 27.3 \\
& 4 members & 6 & 20.0 & 8 & 36.4 \\
& More than 4 & 5 & 16.7 & 3 & 13.6 \\
\hline \multirow{3}{*}{$\begin{array}{l}\text { Group mates } \\
\text { gender }\end{array}$} & Gender does not matter & 14 & 46.7 & 7 & 31.8 \\
& Mixed gender group & 5 & 16.7 & 8 & 36.4 \\
& Same gender group & 5 & 16.7 & 3 & 13.6 \\
& Different working style & 1 & 3.3 & - & - \\
\hline \multirow{3}{*}{$\begin{array}{l}\text { Group } \\
\text { problems }\end{array}$} & Group member & - & - & 13 & 59.1 \\
& Not interested & 7 & 23.3 & 4 & 18.2 \\
& Want to make more & 8 & 26.7 & 5 & 22.7 \\
& No sight of respect & 4 & 13.3 & - & - \\
\hline
\end{tabular}

\subsubsection{Group size}

As stated before, the first camp was more crowded than the second camp but the number of the robot sets therefore the number of the groups at both camps was the same. Therefore at the first camp, the children worked on more crowded groups at the first camp than the second camp. Average group was six at the first camp; however it was four at the second camp.

When the children evaluated their group work, twelve children from the first camp and six children from the second camp stated that group size should be three. They stated that they can work better in three members groups, because their chance of working with the robot will increase and the discussions in small group were lesser than bigger ones. 
R: First of all, what do think about the group members number? How was with three people and 5 people?

Kid.I.05: With five people, it was crowded. We could have arguments between us such as I will do this and you will this kind of things but with three people everything was ok. Everybody takes one mission and it becomes easier.

R: Öncelikle ne düşünüyorsun bu grubun sayısı hakkında beş kişiyle nasıldı üç kișiyle nasıl.

Kid.I.05: Beş kişiyle daha karmaşı oluyordu. Aramızda tartışmalar çıkabiliyordu. Ben опи yapcam sen onu yap gibi ama üç kişiyken herkes şey oluyor. Herkes bir görev alabiliyor. Daha kolay oluyor.

$R:$ So the size of the group; there were four in your group?. For example, three or five or six or even two people in the groups?

Kid.II.21: Could be better with lower size.

$R$ : Lower size. How many people were proper?

Kid.II.21: For example, three is good, two or three.

R: So, you say two or three people are better?

Kid.II.21: Three is good.

R: Peki grup sayısl: dört kişi vardı sizin grupta. Ne biliyim üç kişi olsa veya beş kişi olsa, altı kişi mi olsa, iki kişi mi olsa?

Kid.II.21: Daha az olsayds iyi olurdu mesela.

R: Daha az olsa. Kaç kişi olsa daha iyi olurdu?

Kid.II.21: Mesela üç iyi mesela iki ya da üç.

R: İki ya da üç daha iyi diyorsun.

Kid.II.21: Üç iyi.

Kid.I.14: As group three people is better than four people. Moreover, I feel comfortable also everyone has capability to do.

Kid.I.14: Grup olarak üç kişi dört kişiden daha iyi. Hem daha rahat çalışlyoruz. Hem de herkesin yapabilme olană̆ var.

Six of the children at the first camp and eight of the children at the second camp stated that optimum group size is four; they balanced between the numbers of the ideas, minds and available materials in this case one Lego Mindstorms set and one resource set for each group.

$R:$ What is the ideal number for working?

Kid.I.23: In my opinion, four people is ideal.

$R:$ If it is two or three?

Kid.I.23: When it is two I feel missing. I want more opinion.

R: Çalışma için sence en ideal sayı kaçtır.

Kid.I.23: Bence dört kişi ideal. 
R: Üç kişi veya iki kişi olunca mesela.

Kid.I.23: İki kişi olunca kendimi eksik hissediyorum. Daha çok fikir istiyorum.

R: How are four people inside the group? Would it better lower or higher?

Kid.II.17: For me four people would be better.

R: Bu dört kişi sayı nasıl? Daha mı az olsa daha iyi olur, daha mı çok olsa daha iyi olur?

Kid.II.17: Bence dört kişi daha iyi olur.

However, five of the children from the first camp and three of them from the second one expressed that the group size should be more than four. Therefore, the number of the ideas and minds will increase, the more discussions will be and they will get more benefit from the group work. Also with effective collaborative group work strategies such as task sharing, they can work much more effectively.

$R:$ Is being five or four is comfortable?

Kid.I.28: Five is better. We argue more. We develop our knowledge better. We use our knowledge more. We enforce our mind.

Kid.I.28:

$R$ : While being four?

Kid.I.28: There is not much discussion. If someone thinks like that and three are agrees the last one is just saying ok.

$R$ : If we thinks these missions, is five people better or should it be lower? Is four better?

Kid.I.28: Five people are ideal. One is dealing with materials, one is bringing materials, one is dealing with robot and other one is programming. Sharing could be done.

$R$ : When sharing the work?

Kid.I.28: It is better. Our work is decreasing and also it is becoming quick.

R: Beş kişi mi daha rahat dört kişi mi.

Kid.I.28: Beş kişi daha iyi. Daha çok tartışıyoruz. Bilgilerimizi daha iyi geliştiriyoruz. Daha fazla bilgimizi kullanıyoruz. Beynimizi zorluyoruz.

R: Dört kişi olunca.

Kid.I.28: Biraz fazla tartışma olmuyor. İşte birisi öyle düşünüyorsa. Üç kişi öyle düşünüyorsa diğeri de tamam öyle olsun diyor.

R: Bu görevleri düşünürsek beş kişi daha mı iyi. Yoksa daha mı az olsun. Dört kişi mi daha iyi?

Kid.I.28: Beş kişi tam. Ișste malzemeler ile uğraşıyor. Birisi malzemeleri getiriyor. Birisi robotla uğraşıyor. Birisi program yapıyor. Daha iyi bölünme olabiliyor.

$R$ : Iş̧ bölümü yapınca.

Kid.I.28: Daha iyi oluyor. Işlerimiz biraz daha azallyor. Birde daha çabuk oluyor. 
R: Were the groups with four people proper for the camp or even higher or lower?

Kid.II.18: More is better.

$R:$ So, you say, more people inside the groups are better?

Kid.II.18: We could have finished quickly.

R: Dört kişilik grup daha az olsa daha mı iyi olurdu kamp için. Yoksa daha mı fazla olsa daha iyi olurdu?

Kid.II.18: Daha fazlası iyi.

R: Daha fazla olsa daha iyi olurdu neden daha iyi olurdu?

Kid.II.18: Çabucak hemen bitirirdik.

It could be inferred that the children attended to the camps prefer mostly three or four members groups.

\subsection{Instructors' opinions about group size}

During the second camp, instructors worked with a group like a group mate. They attached a group and responsible the kids at that group. When they evaluated their group work, one of the instructors reflected that group size should be three. The groups with four members are big for the learning stations.

....and groups should be maximum three persons, four is too much. (Instructor 4)

...ve gruplar en fazla üç kişi olmall, dört kişi çok fazla. (Eğitmen 4)

\subsection{Conclusions about group size}

Most of the children from the first camp preferred to work with three members group and most of the children from the second camp preferred to work with four members group. The first camp was more crowded and not orderly as the second camp, therefore the children from the second camp could want to work lesser groups.

\subsection{Design principles for group size}

The group size should be arranged that every child in the group should have duties at any time. If the any group member does not have any work to do, they find something to engage and mostly not related to group work. Engagement of all group members with activities could be achieved by adjusting group size or complexity of 
activities. For the activities similar to activities used in these camps, three member groups are advised, four members group also acceptable, however more than four member groups will be crowded for these activities.

\subsubsection{Group mates' gender}

In this study, the researcher's aim was not reveal the differences or similarities between boys and the girls; aim was to answer the how the groups should be formed at a robotics camp. Therefore, during the camp the children were not faced any gender differentiation. While creating the groups at the first day of the second camp, the groups were created as mixed as possible according to number of the boys and girls. The children from same schools distributed to different groups. During the interviews the children's opinions about the group mates' gender were asked them; fourteen of the children from the first camp and seven from the second camp stated that group mates' gender does not matter, it does not change anything, working with girls or boys do not change anything.

$R$ : Ok, if you were two boys and two girl, how would it be according to you?

Kid.I.08: I think, it would be the same, no change.

R: Peki iki erkek iki klz olsaydı sence nasll olurdu.

Kid.I.08: Bir şey olmazdı. Yine aynı olurdu.

$R$ : So if you were let to form your group, how did you do that? Would you like to have all girls or boys?

Kid.II.14: I am happy with my group, if I had chosen them, I would have chosen same friends.

$R$ : What about the number of girls and boys? Would like to involve in all girl group?

Kid.II.14: It does not matter for me, at last I learn and no problem.

R: Peki sen olsaydın kendi grubunu belirlemen istenseydi nasıl belirlerdin. Yani hepsi kız, mı olsun isterdin hepsi erkek mi?

Kid.II.14: Ben grubumdan memnunum yani isteseydim yine bunlart seçerdim yani arkadaşlarımı.

R: Peki kız erkek sayısı. Hepsi kız olan bir grupta çalışmak ister miydin?

Kid.II.14: Fark etmez benim için yani sonuçta öğreneyim.

Moreover, five kids from the first camp and eight kids from the second camp expressed that they prefer to work in a mixed gender groups. They think that different gender groups could be more productive than same gender groups. Also, the 
researcher's observation support that mixed gender groups perform better because; all girls and all boys groups had more conflict and group problems than mixed groups.

$R$ : According to you, is being mix or if all of you were girl how it would affect?

Kid.I.21: In my opinion being mixed is better. If all we were girls maybe we could not have gotten well. If someone took something I also want to take it but if there are boys we get along with them. Things could go ordered.

R: Sence karışılk olması mı daha iyi yoksa hepsi kız olsa nasıl olurdu.

Kid.I.21: Karışılk olması benim için. Daha iyi. Hep klz olsaydık anlaşamayabilirdik mesela. $O$ aldiğında bende almak isterdim. Ama erkekler ile iyi anlaşabiliyoruz. Stra ile gidebiliyor.

Kid.II.06: It was logical that being 4 people for 24 people. At the beginning we were asking for boys and girsl group but it was not meaningful. There could be problem if only boys and only girsl were inside the groups like I will do that and you will do that kind of things. Sharing was higher when the groups were arranged mixed.

Kid.II.06: 24 kişiye dört kişi mantıklıydı bence. Başta biz hani kızlar erkekler olsun diyorduk ya. Bence birazda anlamsız bir şeymiş. Bu projede kızlar erkekler olsaydı. Böyle bir anlaşmazlıklar çıkabilirdi. İşte ben yapacam sen yapacan gibi. Yani erkek kız karışık olunca biraz paylaşım oldu.

Three boys' and two girls preferences were to be same gender groups in the first camp and three boys and three girls stated that they wanted to work with the same gender group mates in the second camp. As Kid.I.04 explained individual factors such as being a shy person could affect their preferences.

$R:$ So, this four are all boys. If they were mixed, would it be better? Kid.I.04: If they were mixed of boys and girls it would be worse.

$R:$ Why?

Kid.I.04: Because, it would be the thing... This time boys would do the things and girls just watch. In my opinion.

$R$ : Why? If you can do with boys, you can also do with girls.

Kid.I.04: We can be shamed.

R: Peki bu dört kişinin hepsi erkek ya. Bunlar kız erkek karışık olsa idi daha mı iyi olurdu.

Kid.I.04: Kız erkek karışık olsa daha kötü olurdu.

R: Neden.

Kid.I.04: Çünkü. Şey olurdu. Bu sefer erkekler yapar kız bakar kızlar yapar erkekler bakar. Bence öyle. 
R: Niye birlikte erkekler ile birlikte yapıyorsanı kızlar ile de birlikte yapardınız. Kid.I.04: Ama sanki utanırız.

Similarly, Kid.II.10 stated main reason for choosing same gender as group mates is they feel uncomfortable with opposite gender.

$R: O k$, on the first day we grouped you as random, if you had do that how would you form your group?

Kid.II.10: Like what?

$R$ : I we had wanted you to form a group, how would you form it?

Kid.II.10: I would not choose girls?

$R$ : You would not let girls join to group. Why?

Kid.II.10: No reason.

R: Why? Do not girls work and be lazy?

Kid.II.10: No, they are working very well.

$R$ : So, why do not you want them?

Kid.II.10: It is problematic when they are in and I am bored also.

R: Peki biz sizi ilk gün rastgele dağıttı ya gruplara sen olsan kendi grubunu nasil belirlerdin?

Kid.II.10: Nasil yani?

R: Hadi istediğiniz gibi bir grup oluşturun deseydik nasıl oluştururdun?

Kid.II.10: Kız almazdım.

R: Gruba kız almazdın. Neden?

Kid.II.10: İşte.

R: Neden. Kızlar çalışmıyorlar mı tembellik mi yapıyorlar?

Kid.II.10: Yo iyi çalışıyorlar.

R: Peki neden istemiyorsun?

Kid.II.10: Kötü oluyor. Sıkıntılı oluyor. Sıkıllyorum. Kızlar olunca.

Interestingly, one boy expressed that the boys and girls have different working styles.

He stated that, boys work more efficiently than girls on the camp; however girls work more seriously than boys.

$R:$... Is there a difference between boys and girls inside group about working?

Kid.I.11: There is not much difference but boys are working more efficiently but they are sassy sometimes. Girls are not sassy while working, that is they work seriously.

$R$ : They are working seriously.

Kid.I.11: Yes but if boys work, they are more active.

R:...Bu kızlar ile erkekler arasında bir farklılık var mı. Grupta çalışmak açısından.

Kid.I.11: Çok yokta erkekler bence daha verimli çalışıyor. Ama tabi cıvıtıyorlar da. Kızlar bazen cıvitmıyor, yani kızlar daha çok cıvıtmıyor.

R: Daha ciddi çalışıyorlar.

Kid.I.11: Evet. Ama erkekler çalışınca daha etkin çalışıyorlar. 


\subsection{Conclusions about group mates' gender}

The children's opinions about group mates' genders dominated by mixed gender group or group mates' gender does not matter. It is concluded that in a robotics camp the group should be constructed with mixed gender. Moreover, mixed gender group could also help shy children gaining social skills.

\subsection{Design principles for group members' gender}

It is obvious that group in a robotics camps should be constructed with mixed gender group to encourage them to make social interaction with opposite gender and more productive group works.

\subsubsection{Group Problems}

As expected, sometimes the children had problems with their groups. During the first camp, it was observed that children were mostly complained their group mate(s) about giving less chance to them and wants to make nearly all staff by himself/herself. In that situation, the instructors advised to share the task. For example, while combining pieces according to manual, every member should combine the pieces at one page. Group members desire to make more was not a problem at the second camp; however, some of the children's destructing behaviors were the main source of the group problems at the second camp.

Sometimes the children had problems with their groups. When they were asked about the group problems, eight of the children from the first camp and four of the children from the second camp were not satisfied their group members' performance; because they not interested what they working on.

$R:$ For instance, what did you do? What was hard for you?

Kid.I.30: I had hard times with my friends. $R$ : With your friends, what kind of things?

Kid.I.30: My friends did not do anything. All the things was done by me and my friend Abdullah. In that day, we were very tired and we were in asleep in the school bus.

$R$ : You were in asleep in the bus?

Kid.I.30: They do nothing, they just talk each other. 
R: Mesela ne yaptın neydi o zorlandı̆̆ın zamanlar

Kid.I.30: Zorlandı̆̆ım zamanlar arkadaşlarımla oldu

R: Arkadaşlarınla oldu ne gibi

Kid.I.30: Arkadaşlarım hiçbir şey yapmadı hep Abdullah diye arkadaşımız bütün programları filan hep ona yaptırdı arkadaşımla ben sadece biz yaptık iki kişi işıte o sadece biz yaptık biz o gün hatta çok yorulduk serviste uyuyorduk nerdeyse

$R$ : Serviste uyuyordunuz nerdeyse

Kid.I.30: Hiçbir şey yapmıyorlar sadece konuşuyor sohbet ediyorlar

$R:$ Ok, did you have any problem with your group members?

Kid.II.09: Yes. When I was in my old group, Kid.II.12 and I were very curios and we were trying to do something every time. When I was involved in the group, we were trying to do flower watering machine. We were trying to do its hand and boys were playing with the computer. We were working but they were dealing with something else. It was a bit problematic. While they were playing with computer I was fed up with doing it and I did not want to do.

R: Peki grup arkadaşların ile her hangi bir problem yaşadın mı?

Kid 09: Evet. Eski grupta birinci gruptayken şöyle bir şey vardı. Kid 12 ve ben genel de çok meraklı olduğumuz için sürekli bir şeyler yapmaya çalışıyoruz. Ne bileyim ben projeye geçtiğimiz zaman çiçek sulama robotu yapmaya başlamıştık. Biz orada elini yapmaya çalışıyoruz. Erkekler orada bilgisayar la oynuyorlar. Biz yapıyoruz işte onlar başka bir şeyle uğraşıyorlar. İşte o biraz sıkıntı oldu. Onlar yine bilgisayar ile oynarken artık bezdim kendimden yapmak istememiştim.

Similarly complaints about not interested group members reflected on the evaluation forms.

Kid.I.03: In the last days of the camp we started a new Project. $U$ was working hard for the Project but others were not working. Everybody should work and do something.

Kid.I.03: Kampımızın son günlerindeyiz ve bir projeye başladık. Ben bu proje için çok çalışlyorum, arkadaşlarım hiç çalışmıyor. Herkes çalışıp biraz uğraşmalı bence.

Although, the instructors warned about them to work together with respectfully and advised to combine pieces with task sharing or with a queue, seven of the children from the first camp complained about their group members had wanted to make more and gave less chance to them. Similar to the first camp, some of the children wanted to make more on work and give less chance to group mates at the second camp. Although, each groups' instructors warned them to work respectfully to the group mates' rights; five children complained about the group mates not to respect their rights. 
$R$ : Ok, Could you evaluate the interaction among the group? Like sharing missions and other distributions.

Kid.I.03: Yes, we do it. It was also valid when XXX was here but there were some people who did not care it. XXX knew it. She did this. She was saying that we were deciding for everyone like you do this and you this kind of. We were doing what we told but later XXX saw that her mission was hard or short. She said that I do two things. I did not like her behavior.

R: Peki grup içerisindeki etkileşimi bir değerlendirebilir misin? Hani grup arkadaşınla paylaşımlar görev paylaşımı.

Kid.I.03: Evet onu yapıyoruz zaten. XXX varken de o vardı. Ama mesela hani uymayanlar vardl. XXX biliyordu. Şey yapıyordu. Diyordu ki herkesin ki gibi kararlaştırıyorduk. Sen şunu o şunu gibi. Siz şunları yapacaksınız diye yapıyorduk. Ama sonrasında XXX baktı kendi aşaması kısa geldi veya zor geldi böyle derken. O hemen diyordu banane banane ben işte iki aşama yapayım. Bunu beğenmedim.

$R$ : So, did you have any problem with your friends?

Kid.II.20: I had some problems with Kid.II.18.

R: Yes, you are in the same group with Kid.II.18, what kind of problems did you have with Kid.II.18?

Kid.II.20: Kid.II.18 does not help much. He wants to do everything alone and when he cannot he blames us.

R: Peki grup arkadaşlarınla herhangi bir sorun yaşadın mı?

Kid.II.20: Biraz Kid.II.18'le sorun yaşadım.

R: Evet Kid.II.18'in grubundasın sen, ne gibi sorunlar yaşadınız Kid.II.18'le?

Kid.II.20: Kid.II.18 çok yardım etmiyo. Her şeyi kendi yapmak istiyor yapamayınca da suçu bize atıyor.

Four of the children stated that they want to be respected. They complained about some group members who they did not care their ideas during group work. Moreover, some of the children's bad language was another complained disrespectful behavior. However, the kids from the second camp did not mentioned selfish behavior of a group member.

Kid.I.07: I have two things with my group and robot. There were rude things among the group. They call people as "Lan" and also they were mocking. I was telling something very seriously and want them to make like that but they were saying me "Do not be silly!". I mean, they were not taking my ideas. For instance something should be done one by one but they were breaking the queue and it was torture.

Kid.I.07: Ya hani grupla ilgili bi de robotla ilgili 2 tane şeyim var. Hem hani gruplarda şey oluyo mesela saygısızlık oluyo işte. Lan man gruplar arasında bi de kendi grubumuzda mesela işte dalga geçiyolar. Ben çok ciddi bişi söylüyorum 
mesela bunu böyle yapalım diyorum işte saçmalama yok bu olmaz hani benim ordan giriyo ordan çıkıyo hani benim dediğim görüşümü almıyolar. Hani mesela bunu sıra sırı yapcaz. Hani işte sırayı bozdum ben bana böyle bi eziyet yapmış gibi oluyo böyle bakıyorlar.

In the second camp the instructors had problems with some children. Especially some of the divorced parents' children attended from governments special dormitories. It was hard to handle them and keep them on the subjects. Most of the children also complained about these boys. Thirteen of the children stated that main group problem was their group mates.

$R:$ So, what is the reason for the problems with $X X X$ ?

Kid.II.03: He is talking very rude. We do not get on well.

$R:$ So, are those problems solved?

Kid.II.03: No.

$R:$ Did the instructor interfere to these problems?

Kid.II.03: Yes, they did but he did not listen to them.

R: Peki, XXX ile yaşanan problemler neden oluyor sence?

Kid.II.03: Çok kaba konuşuyor. Hiç anlaşamıyoruz.

R: Peki bu sorunlar çözüldü mü?

Kid.II.03: Hayır.

R: Eğitmen bu sorunlara müdahale etti mi?

Kid.II.03: Ya ediyorlar da hiç dinlemiyor ki.

Moreover, complains about some of the group members reflected on the most of the evaluation forms.

Kid.II.02: Our friend called Kid.II.18 did not help us. He disturbed us but we were good with other friends and helped each other.

Kid.II.02: Kid.II.18 adlı arkadaşımız bize yardım etmedi, bizi rahatsı etti ancak diğer arkadaşlarımla çok iyi anlaştık ve hep birbirimize yardım ettik.

\subsection{Instructors' Opinions about Group Problems}

As stated in camps' diaries parts, the groups defined by a game at the first camp however at the second camp children were given a number between 1 to 6 and all the children with the same number created a group. One of the instructors stated that, defining the group with giving number was good because all the friends (and same gender) sitting together therefore this method separate them perfectly.

I think it was very good especially, 1-2-3-4-5-6 was very good. In my opinion, it was good to get authority at first day. What we said had happened. They completely separated with 1-2-3-4-5-6 
because all friends sitting together and the girls were ready to become spoiled. One separated to a group, another separated to other group that method was super. Bu maybe before that we could play a game (Instructor 1).

Bence çok güzel oldu, 1-2-3-4-5-6 çok güzel oldu. Bence ilk günü otoriteyi hop diye ortaya koymak iyi oldu. Bizim dediğimiz oldu. Ya zaten direk ayrıldılar kızlar çok kötüydüler ay ben şu tişörtü giymem ay ben onla olmam kızlar şımarmaya hazırdılar. 1-2-3-4-5-6 Yaptık zaten bütün arkadaşlar yan yanaydl. Biri o guruba biri bu guruba o metot süper oldu. Ama belki ondan önce oyun oynayabilirdik. (Eğitmen 1)

Assigning each group an instructor prevented many of the problems before they emerged. Instructor 3 stated that at the first camp some of the children's complains about carelessness. However, at the second camp, the instructors and the responsible group were defined and the children did not have such expectation.

When we went to a group, other groups asked us why you did not come to us (at the first camp). The children knew their own groups so they did not said that you did not come to our group, because every child worked with each instructors (Instructor 3).

Bir gruba gitsek diğer grupta niye sen bize gelmedin diyebiliyordu (Birinci kampta). Burada çocuklar kendi gruplarını bildi ve sen bize gelmedin gibi olaylar olmadı. Çünkü herkes o grupta o abi ve o ablayla çalıştı. (Eğitmen 3)

Moreover, when an instructor assigned to each group, the instructors' responsibilities were clearly defined. Therefore, the instructors were aware of children he/she responsible. As instructor 2 stated, a child and responsible instructor were obvious in the second camp.

I my opinion, especially stations was very successful because every instructor had the students to be responsible. For example, when I saw Kid II.18, I could say where you were Kid II.18. The Kid could say that the instructor 5 was responsible from me. When I saw a child, I knew which instructor was responsible for him. Other way (first camp) was too much free (Instructor 2).

Özellikle istasyonlar çok başarılıydı bence, çünkü her bir öğretmenin sorumlu olduğu ögrenciler vard. Mesela ben Kid.II.18'i gördüğüm zaman diyebiliyordum Kid.II.18 nerdesin? Eğitmen 5 deyim o Eğitmen 5 in sorumluluğunda. Ya da birisini gördüğ̈̈mde hangi ablanın ya da abinin sorumluluğunda biliyordum. Diğer türlü (birici kamp) çok serbest oluyorlar. (Eğitmen 2)

With the instructor and group match, classroom management was also easier and the noise level of the camp environment was quite low at the second camp. Instructor 1 
stated that she was impressed when the children had been working at the second camp.

I remembered the other project (the first camp), there was always someone in the middle who was walking around constantly. In the station works (second camp) I was looking for a class and when I saw everyone worked hard, I felt that what a good thing that was super... (Instructor 1)

Ben diğer projeyi hatırlyyorum (birinci kamp), sürekli dolaşıyorlardı sürekli ortada birileri vardı. Hele istasyonda (ikinci kamp) ben şöyle slnıfa bir bakıyorum en köşedeyim ya bide, herkes harll harıl çallşlyor. Allah'ım ne güzel süper bir şey falan diyordum... (Eğitmen 1)

In the design phase of the second camp the instructors had not been informed about grade levels of the children and they had been thinking that the $6^{\text {th }}$ grade students would attend the camp. They prepared the instruction especially the stations for the $6^{\text {th }}$ grade. In programming part of the camp that was not a big deal, because all the children had not known the programming and programming was a new thing for them. Therefore, programming section could grasp their attention. However, in stations sections, some of the children had already familiar the related science or mathematics concepts. Therefore, these affected the children motivations toward that station.

In the part of analysis, we did not know the students come from different grades (6-7-8). Therefore, the students were not the same classes and it was really big problem. Each group has $6^{\text {th }} 7^{\text {th }}$ and $8^{\text {th }}$ grades children. Now I've noticed that six grades students were more interested in the camp. Imagine that the small junior were much more concerned with the camp. If $7^{\text {th }}$ and $8^{\text {th }}$ grade did not attend the camp, $6^{\text {th }}$ grades could be more motivated toward velocity activities (Instructor 1).

Bi kere analiz kısmında biz öğrencilerin 6-7-8 olacă̆ını bilmiyorduk. Bu çok büyük bir problem oldu kesinlikle aynı sinıftan olmamaları sınıf seviyelerinin farklı olmaları bütün gruplarda 6'da vardı 7'de 8'de öyle bir dağıtmışı ki yani buna göre şimdi genelde benim fark ettiğim 6.sinıflar daha çok ilgiliydiler. Düşünün o küçük ufaklıkları onlar çok daha ilgiliydiler. Eğer etkinlikler 8 ler falan olmasaydı 8-7 belki 6 lar yine o hız etkinliklerinde onlarda da çok hevesli motive olabilirlerdi yani. (Eğitmen 1)

Moreover, that was also affected, children are 5-6-7-8 th grades they says; "aaaa I already have know that" and it does not get attention. (Instructor 3) 
Ya bide şeyde etkiledi bence hani 5-6-7-8 ya bir şey oluyor aaaa ben bunu biliyorum diyor çok hani ilgisini çekmiyor. (Eğitmen 3)

The consensus of the instructors' opinion is the grade level of the children or children's prior knowledge about the concept should be same for effective instruction.

\subsection{Conclusions about Group Problems}

"Group member", "not interested group members", "wants to make more" and "no sight of respect" are causes of the group problems emerged at this study.

While designing a robotic camp, the instructors should be aware of these possible causes. Assigning an instructor to each group could prevent some group problems. For example, the instructor can manage task sharing; can get interest of the children toward activities and the children should be more respectful toward group mates in existence of an instructor in the group.

Encouraging task sharing or division of the labor could give equal chance to each member to join group work. Therefore, each group members will be aware of how much he/she could do and group mates' rights.

\subsection{Design principles for group problems}

Because a robot is an interesting toy for children, the children wants to engage more time with them even without giving chance to group mates. On the other hand, some of the children feel isolated and does not interest what the group mates are doing and engage different things. Task sharing and division of labor should be encouraged during a robotics camp to eliminate both problems.

As the instructors stated, the children who attended to a robotics camps should be at the same age. Therefore, the children will understand each other more easily and during STEM activities, the instructor could define level of the activities. 


\subsubsection{Competition}

While designing the robot camps; one of the important decisions was whether the camp will be competitive or not. That was a dilemma, because the races and tournaments will increase the children's motivation and would be the source of the fun. Although, there was not any prize at the end of the contests, there would always one winner and the rest will feel they were defeated. Therefore, it was decided that, there will be competition at first camp but it will be explained the children, the races and contests are just for fun, the results should not be exaggerated. However, competition was kept at minimum level at the second camp.

Although, there was any encouragement for competition at the second camp, during the interviews the children's opinions about competition were taken from all children. Competition related concepts and their frequencies are shown at Table 4.13.

Table 4.13

Competition

\begin{tabular}{llcccc}
\hline \multirow{2}{*}{ Category } & Sub-category & \multicolumn{2}{c}{ I. Camp } & \multicolumn{2}{c}{ II. Camp } \\
& & $\#$ & $\%$ & $\#$ & $\%$ \\
\hline \multirow{5}{*}{ Positive } & 22 & 73.3 & 7 & 31.8 \\
& Negative & 9 & 30.0 & 7 & 31.8 \\
& Tournament event & 15 & 50.0 & - & - \\
& Desire to be the first & 3 & 10.0 & - & - \\
& Gentlemanly contest & 1 & 3.3 & - & - \\
& Contest give value to camp & 1 & 3.3 & - & - \\
& Self-competition & - & - & 14 & 63.6 \\
& No competition & - & - & 6 & 27.3 \\
\hline
\end{tabular}

At the first day of the first camp, the robot sets were distributed and while children were combining the pieces accordingly to the manual, the researcher was walking between the groups and looking their progress. One child said that with enthusiasm: 
-We are the first.

-Biz birinciyiz.

Their progress was further than the other groups, and they nearly finished their robot, however, the instructors did not announce any competition. The child put himself into a self-competition. Moreover, during the camp it was observed that, the children spend more effort when they were programming their robots for races or tournaments. At competition time, they worked more seriously and more collaboratively with their group.

Twenty two of the children who attended to first camp and seven of the children from the second camp think that the competition was positive and they emphasized that they work more seriously when there was a competition like Kid.I.27 stated.

$R$ : At the beginning, we had competitions. What do you think about those competitions?

Kid.I.27: I think the competition is better.

$R$ : Why is it better?

Kid.I.27: For example, Mustafa does not accept the loss. You learn to accept the loss. Then, you congratulate the winner. For instance, Mustafa does not do such things. He never says to you that you did good robot. Moreover, everyday one group takes the flag. Everybody applaud to them and if one person does not applaud, the group members sadden.

$R$ : So, the group who wins saddens.

Kid.I.27: Yes.

$R:$ So, is such a competition atmosphere good?

Kid.I.27: Yes, you try to do belter robot to win the competition, to become belter.

R: İlk zamanlar yarış yapıyorduk. Yarışlar hakkında ne düşünüyorsun?

Kid.I.27: Yarışma bence daha iyi...

$R:$ Neden daha iyi?

Kid.I.27: Mesela Mustafa yenildiği zaman yenilgiyi kabul etmiyor. Yenilgiyi kabul etmeyi öğreniyorsun. Sonra yenen kişiyi tebrikliyorsun. Mesela, Mustafa öyle şeyler yapmıyor. Hiç yanına gidip siz çok güzel robot yapmışsınız demiyor. Bir de, biz artık şey allyoruz ya, bayrak, o bayrakta mesela hergün bir kişsi alıyor, bir grup alıyor. O zaman herkes alkışlıyor, biri alkışlamadı̆̆ zaman o gruptaki kişiler biraz üzülïyor.

$R$ : Alan kişiler üzzülüyor yani...

Kid.I.27: Evet.

R: Peki böyle bir rekabet ortamının olması güzel mi?

Kid.I.27: Evet, daha iyi robot yapmaya çalışlyorsun. Biz birinci olalım, biz iyi olalım diye... 
$R:$ Ok, is rivalry good for you?

Kid.II.02: It is good for me.

$R$ : Are there any problem when there is a rivalry.

Kid.II.02: When there is rivalry, we become more determined. We

work more.

R: Peki rekabet olmasl sence güzel bir şey mi. Yoksa?

Kid.II.02: Iyi bir șey bence.

R: Sorun çıklyor mu peki rekabet olunca?

Kid.II.02: Rekabet olunca daha azimli oluyoruz. Daha çok çalışıyoruz.

In one of the evaluation form, Kid.I.24 put into word his request of contest like:

Kid.I.24: In my opinion, when sensor was put on it, there should have been a mission and competition.

Kid.I.24: Bence sensör takılınca bir görev verilmeliydi ve yarış olmallydl.

Nine of the children at the first camp and seven of the children at the second camp think that competition was negative. There were two reasons for it. Firstly, in the competition case, they wanted to be the winner and they worked for it. However, while working for contest they felt much more stress. Therefore, the stress affected their performance.

$R$ : What do you think about the competitions?

Kid.I.11: There are competitions already. We can win or lose. When worked so much it makes unhappy when you lose.

$R$ : Even there is not a reward, you become unhappy?

Kid.I.11: Yes.

$R: O k$, in the evening when we say, there is competition, is the work more funny and efficient?

Kid.I.11: For me, it is a bit stressful.

$R$ : Rivalry? Is competition something stressful for you?

Kid.I.11: Yes.

$R:$ So, why are you becoming stressful?

Kid.I.11: For doing fast and win it. I could not do or cannot be done like kind of things.

$R$ : This is the source?

Kid.I.11: Yes.

R: Ne düşünüyorsun yarışmalar hakkında.

Kid.I.11: Ya zaten yarışmalar oluyor. Kazanmakta var kaybetmekte. O kadar çalışlyorsunda kaybedince öyle bir üzülüyorsun.

$R$ : Ödül olmasa dahi üzülüyorsun.

Kid.I.11: Evet.

R: Peki akşam yarışma var dediğimizdeki çalışma daha mı eğlenceli daha mı verimli oluyor.

Kid.I.11: Benim için bana biraz stres veriyor.

R: Rekabet olması? Yarışma olması stres mi yaplyor? 
Kid.I.11: Evet.

R: Peki neden stres oluyorsun.

Kid.I.11: Hemen yapayım. Kazanayım. Yetiştiremiyeceğim. Böyle olmuyor filan

diye.

$R: O$ stres yaplyor.

Kid.I.11: Evet.

Second reason is the results of the contests as thought before the camp. Although, there was not any prize at the end of the contest, the children gave too much emphasis on the result of the contest than the researcher's expectation. As Kid.I.20's term; they turned the situation to "a matter of life and death".

$R$ : We were doing competitions at first times. There was rivalry between the groups. What do you think of those competitions?

Kid.I.20: We won of those competitions. Was it "golden girls" or "inventor girls". I think it was "inventor girls". We won with draw but we were chosen as the winner. I was very happy however in the other game even we did the right program, we had put it to the wrong file so we made it very important for us and became unhappy.

$R$ : Did you make it?

Kid.I.20: Yes. For example, Kid.I.18 went to his side and put his head to the table like that. He said himself like that. Later, everyone started arguing each other before giving order each other.

R: Biz ilk zamanlar yarışmalar yapıyorduk. Gruplar arast rekabet vardl. Ne düşünüyorsun yarışmalar hakkında.

Kid.I.20: O yarışmanın birinde kazandık. Altın kızlar mıydı? Mucit kızlar miydı? Her halde mucit kızlardı. Íkimiz berabere kalmıștık. Ama birinci seçilmiștik. O açıdan çok sevinmiştim. Ama daha sonra öbür yarışta kendimiz doğru programı yapıp ta yanlı̧̧ dosyanın içine attığımız için resmen hayat memat meselesine çevirmiştik.

R: Siz mi çevirmiştiniz.

Kid.I.20: Evet. Mesela Kid.I.18 şöyle geçti yerine şöyle kafasını masaya yasladı. Şöyle kendi kendine laf attı falan. Daha sonra herkes birbiri ile tartısmaya başladı. Görev vermeden önce birbirimize.

$R:$ Would the camp more funny if there were competition?

Kid.II.16: This is better in my opinion because there could be problems such as doing better if there were competition. There could be sulks between us. This is the best.

R: Yarışma ortamı olsa daha mı iyi olurdu. Daha mı eğlenceli olurdu kamp? Kid.II.16: Böylesi bence çok daha iyi. Çünkü yarışma olsa ben daha iyi yapcam ben daha iyi yapcam kavgalar olabilirdi. Küslükler olabilirdi. En iyisi böyle.

As explained in the diary of the first camp section, at the fourth day of the camp they made a tournament. After the tournament, some of the groups objected to result of 
the tournament because they thought that the winner group got some extra help. It was the hardest discussion and the worst event of the camp. The instructions tried to explain it was not so important but the children had already made it a matter of life and death. The tournament result did not change, but other children disturbed from the discussion and objections. Fifteen of the children express their discomfort from that event.

$R:$ We created a rivalry situation. What do you think of it?

Kid.I.14: There were unnecessary arguments. It was a bit sad event. In my opinion there was no need to make it bigger. It is just a competition. I do not care things like that.

R: Bir şekilde rekabet ortamı oluşturduk. Bunun hakkında neler düşünüyorsun Kid.I.14: Saçma tartışmalar yaşandı. Biraz üzücü bir olaydı. Ama fazla büyütmeye gerek yok bence. Altı üstü bir yarışma bence. Ben pek önemsemiyorum böyle şeyleri.

Children reflected their opinions about that incident also on that day's evaluation forms.

Kid.I.18: Something I faced with as negative; we made a competition. Everybody had arguments and fighting on it. In my opinion those things are unnecessary. We do not need these arguments.

Kid.I.14: Olumsuz olarak yaşadı̆̆ım olaylardan biri; bir yarışma yaptık. Herkes onun üstüne tartışmalar, kavgalar yaptı. Bence bu tür şeyler çok saçma. Ne gerek var böyle tartışmalara.

As exampled before, some of the children intrinsically want to be winner although they are not in a competitive environment. Three of the children stated that they have desire to be the winner. They gave a value to the winner intrinsically. As Kid.I.18 expressed, they wanted to be the winner therefore their friends and instructors could recognize them.

$R:$ What do you think while you are here?

Kid.I.18: Finishing the robot as soon as possible and showing you. R: Why is this so important? Is showing as soon as possible important?

Kid.I.18: Yes for me. Finishing earlier than everyone.

$R$ : Why doing early and showing before everyone is so important for you?

Kid.I.18: Why important. Finish earlier than everyone and taking well done from you. 
R: Burada iken neler düşünüyorsun.

Kid.I.18: Robotu bir an önce bitirip size göstermeyi.

R: Bu neden bu kadar önemli. Hani bir an önce göstermek önemli mi?

Kid.I.18: Yani benim için. Bir an önce herkesten önce bitirmek.

$R$ : Önce yapıp göstermek neden senin için önemli.

Kid.I.18: Neden önemli. Herkesden önce bitirip yani bana aferin demeniz. O.

Although the tournament events and its' bad consequences, during the interviews two-third of the children expressed their positive thought about competition. That shows somehow group competitions should be part of this king of camps. However, the answer of the big question "how should competition be structured?" was also given by the children. Kid.I.22 emphasized that if the completion was structured, contests should be done in a gentlemanly manner. They should not discuss the result of the contests.

R: What do you think of the competitions we made at the beginning?

Kid.I.22: In the competitions, for instance if a group loses it, they work. They argue on it and it is bad. During the competitions, we should be gentlemen and have respect to others.

$R$ : Which one is good, having competitions or not?

Kid.I.22: In my opinion, having competitions is better but it should be like this. Groups should not have arguments among them. I mean, they should not argue it there is a competition. If they will argue, there should not be any competition.

$R$ : İlk zamanlar yaptığımız yarışmalar hakkında neler düşünüyorsun.

Kid.I.22: Yarı̧̧malar da mesela bir grup kaybedince bir grup ta çalı̧̧ma ya gidiyor. Tartışlyorlar. $O$ kötü oluyor mesela. Yarışma yapllırken centilmen davranılmalı bence. Birbirlerine sayg gösterilmeli.

R: Yarışma olması mı olmaması mı daha iyi.

Kid.I.22: Yarışma olması daha iyi ama şöyle olmalı. Gruplar arasında tartı̧̧mamaları lazım. Yani yarışma olacak ise tartısmayacaklar. Eğer tartışacaklar ise yarışma olmasin bence.

Moreover, Kid.I.28 explained that the contests gave value to the camp, when they work for contest they made discussion and exchange their ideas. They liked worked this way. However, without contests, they worked unwillingly and just hanged out.

$R$ : Ok, we had some competitions, what do think of these competitions?

Kid.I.28: Competitions were good but sometimes robots were not doing what we wanted from them so we were unhappy in these times. We were becoming angry so we did not want competitions.

$R$ : Should competitions be or not?

Kid.I.28: It is both good if there are competitions or not. 
$R:$ If there are competitions, why it is good?

Kid.I.28: When there are competitions, a rivalry exists among us. We have arguments. We talk about doing something like this and doing other like this. If we do like these things become fast. We can have meetings during the competitions.

$R: O k$, if they do not exist?

Kid.I.28: If there are not competitions, we argue less. We do not give importance to the competition and it is not good.

$R$ : When there are competitions, you work more efficiently. With no competition, you do not care?

Kid.I.28: Yes. We fool away the time. For example, we finish the robot and have the remaining time with competition. Now there is no competition so we sit usually. We try to set something. We are busy with them.

R: Peki biz bir ara yarışmalar yapıyorduk. Ne düşünüyorsun yarışmalar hakkında

Kid.I.28: Yarışmalar güzeldi de robotlar bazen istediğimizi yapmıyordu. O yüzden de canımız çok sıkılıyordu. Sinirleniyorduk. O yüzden fazla yarışma yapmayı istemiyorduk.

$R$ : Yarışma olsun mu olmasın mı?

Kid.I.28: Olsa da güzel olmasa da güzel.

R: Olsa da neden güzel?

Kid.I.28: Olsa aramızda bir çekişme oluyor. Tartışmalar oluyor. Şunu şöyle yaparız bunu böyle yaparı. Böyle yapsak daha hızll gider daha fazla döner gibi. Tartışmalar yapabiliyoruz yarışmada.

R: Peki olmasa nasil olur?

Kid.I.28: Olmasa biraz az tartışma yapıyoruz. Fazla yarı̧̧ma üzerinde durmuyoruz. Pek de güzel olmuyor.

R: Yarışma olunca daha da etkin çalışıyorsunuz. Yarışma olmayınca daha da böyle boş veriyorsunuz.

Kid.I.28: Evet. Biraz boş geçiyor vaktimiz. Mesela robotu bitiriyoruz. Kalan zamanı yarışma ile geçiriyoruz. Öbür günlerde. Şimdi yarışma yok o yüzden oturuyoruz. Bir şeyler takmaya çalışıyoruz. Onlara uğraşıyoruz.

At design phase of the second camp, the instructors decided to keep competition at minimum level at the second camp. However, some instructors asked some questions or took each child's guess or hypothesis about the result and compared them at learning stations. During the interviews, the children evaluated these activities as competition. However, the instructors never encouraged them for group competition. But, some of the children especially Kid.II.06, visited the other groups and challenged them that her group does it better of faster.

Fourteen of the children stated that somehow they put themselves into the selfcompetition (self means the children challenged themselves, the instructors did not encouraged them). They mostly mentioned about Kid.II.06 behaviors. 
$R:$ So between the groups, was there a competition kind of things? Have you felt like that during the camp?

Kid.II.11: Only a girl called Kid.II.06 was coming to our side and telling that our robot was bad and theirs was good.

R: Peki gruplar arası böyle bir yarışma tarzı bir şey var mıydı? Kamp boyunca hissettiğin?

Kid.II.11:Sadece bir kız, Kid.II.06 geliyordu. Kid.II.06 de bizim robotumuz iyi oluyor. Sizin ki kötü oluyor. Diyordu.

The rest of the children at the second camp $(\mathrm{N}=6)$ stated that there was not any competition.

Students' data revealed that the children liked completion in the robotics camps. Even though, the tournament event (unwanted consequences of the competition) the children prefer to work in a competitive environment. If the camp was not competitive, they create their competition between themselves.

\subsubsection{Instructors' opinions about competition}

Kid.II.06 behaviors also noticed by the instructors. Instructor 4 reflected the complaint of the children in her group about the Kid.II.06 behaviors mostly challenge and detraction about their projects.

R: ...yes Kid.II.06 was used it for self-motivation.

Instructor 4: She breaks others motivations. Kid.II.05 complained her, also Kid.II.21 said that please don't come our table.

Instructor 1: I think that Kid.II.06 motivated himself as using the way. She had really high motivation.

R: ...evet Kid.II.06 kendini öyle motive ediyor.

Eğitmen 4: Karşısındakinin moralini inanılmaz bozuyor. Kid.II.05 şikayet etti, ya da Kid.II.21 gelmesin artık yeter dedi kaç kere masalarına gidip yok ne dandik yok şu yok bu...

Eğitmen 1: Bence kendini o şekilde motive ediyor. Kid.II.06 motivesi çok yüksek bir ögrenci yani aslında.

The instructors also criticized selection of "the group of the day" at the first camp. According to them, it moved away the children from the aim of the camp.

Instructor 2: In the first camp we selected the group of the day at the end of the each day. They come to us and asked to choose them.The aim was...

Instructor 4: Became the winner instead of to learn. 
Eğitmen 2: Eski grupta (birinci kamp) biz birincilere her günün sonunda birinci seçip masaya bayrak koyuyorduk ve bir yarış vardı ve öğrenciler sürekli yanımıza gelip abla beni birinci seç artık. Amaçları şey olmuştu

Ĕ̆itmen 4: Öğrenmek değil de birinci olmak.

Moreover, Instructor 1 mentioned about a bad sequences of competition in her learning station at the second camp.

Kid.II.16's group was too bad in my station work. Because of competition the group separated as girls and boys." Are they faster than us", "I could not make" they turned to another dimension. (Instructor 1)

Bizim işte şu diyorum ya Kid.II.16 lerin bizim istasyonda çok kötüydü. Onun sebebi rekabetti onlar ayrlldlar kızlar erkekler diye. Onlar mı çabuk yaptı abla biz mi çabuk yaptık ben yapamadım bilmem ne böyle farklı bir boyuta dönüştü. (Eğitmen 1)

\subsubsection{Conclusions about competition issues}

Although some negative consequences of competition, like tournament event at the first camp, most of the children's opinions about competition was positive. Moreover, especially at the second camp, it is observed and most of the children stated existence of self-competition. Therefore, competition should be a part of a robotic camp. As the instructor stated, competition should not be over emphasized like selecting "the group of the day" to keep them quiet.

\subsubsection{Design principles for competition}

When design phase of a robotics camp curriculum, tournaments and races should be arranged to increase children motivation toward the activities and it will make the camp more entertaining. However, competition should not be over emphasized and causes to misunderstandings. It should be clearly defined that tournaments and races are just for fun and motivation and the children should not predicate another meaning to the results of the competitions. 


\subsubsection{Coaching}

The fourth sub-question of the study is related to coaching issues at a robotic camp. Meaning of coaching is the monitoring of the learners' activities and when it necessary assisting and supporting them (Dennen, 2004). Coaching involves giving cues or hints, providing feedback, redirecting students' efforts, and helping them use a strategy. The main principle of coaching is to giving the right amount of help when learners need it neither too much nor too little therefore learners retain as much responsibility as possible for their own learning (Tinzmann et al., 1990). According to Jonassen (1999), a good coach should motivate learners, analyze their performances, provide feedback and advice on the performances and how to learn about how to perform, and provoke reflection on and articulation of what was learned.

During the camps the instructors main duties was coaching the children's work with robots. It was observed that the children were much more enjoyed their process when they guided and solved their problems their own. Because the camps' curriculum based on constructionist view which sees children as the active builder of the their knowledge (Kafai \& Resnick, 1996; Maxwell, 2006), the instructors' main responsibility is coaching children's learning. During the camps, the instructors did not give direct answer of the problems; they gave some hints about how they should solve problems. Table 4.14 presents frequencies of the coaching category from the both camps.

Table 4.14

\section{Coaching}

\begin{tabular}{llccccc}
\hline \multirow{2}{*}{ Category } & \multirow{2}{*}{ Sub-category } & \multicolumn{2}{c}{ I. Camp } & \multicolumn{2}{c}{ II. Camp } \\
& & $\#$ & $\%$ & $\#$ & $\%$ \\
\hline Coaching & Coaching & 17 & 56.7 & 2 & 9.1 \\
\hline
\end{tabular}


Seventeen of the children stated that the instructors had not given the direct answers and therefore they learned better from the camp.

$R$ : It was hard for you to program. How did the instructors help you?

Kid.I.29: Instructors helped us about all the things that we could not do but they did not do it directly, they just gave us opinion and we make them check it.

$R$ : Ok, The instructors did not do for you, just show and gave tips. Could you evaluate this? Is this a good thing? If they had done it for you, your work should have been less.

Kid.I.29: Yes, like this it would be easier but we came here to learn and make robot if they do the job it would not be meaningful. They would learn for us and we do not learn anything.

R: Programları yaparken zorlandınız. Eğitmenler sizlere nasıl yardımcı oldular. Kid.I.29: Eğitmenler bize yapamadı̆̆ımız her konuda yardım ettiler ama hepsini de onlar yapmadılar tabi bize sadece fikir verdiler biz yaptık kontrol ettirdik işte öyle.

R: Peki şey diyeceğim ĕgitmenler onlar yapmadılar size sadece gösterdiler bir ipucu verdiler. Bunu değerlendirir misin? bu iyi bir şey mi? Hani yapıp verseler sanki işiniz daha da kolay olurdu gibi.

Kid.I.29: Ya öyle tabi daha kolay oludu da bizim buraya sonuçta biz ögrenmek için geliyoruz robot yapmak için geliyoruz onlar yaparsa hiçbir anlamı olmaz zaten onlar biliyor. O zaman onlar öğrenmiş olurlar. Biz hiçbir şey öğrenmiş olmayız.

Unlike the first camp, only two children were mentioned about the instructors' encouragement them to learn themselves. Kid.II.01 stated that he was given chance to discover some concept at the camp.

R: About the education given at the camp; how would it be? Would it be given or would you explore yourself?

Kid.II.01: We have explored ourselves, it would be funnier and hard, that is we would have been rehearsed when we learnt.

$R$ : What was missing in this camp from that point?

Kid.II.01: Nothing was missing from that point.

$R$ : Were you let to explore or learn yourself?

Kid.I.01: Yes, we were.

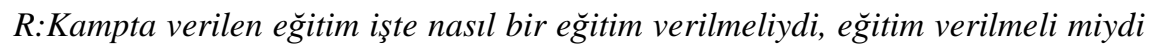
kendiniz mi keşfetmeliydiniz?

Kid.II.01: Biz kendimiz keşfettik daha eğlenceli ve daha zor olurdu yani ögrenince tam otururdu.

R: Evet. Bu kampta mesela ne eksik oldu o yönden?

Kid.II.01: $O$ yönden bir eksik yok bence.

R: Peki sizin keşfetmenize veya sizin kendi başınıza öğrenmenize izin verildi mi?

Kid.I.01: Verildi. 
Moreover, Kid.II.06 expressed that the instructors gave clues about the solution for the problems.

R: Did the instructors help you about this problem?

Kid.II.06: Yes, they did.

$R:$ For example, what did the instructor?

Kid.II.06: For instance, they gave hints about the problem. They

helped.

R: Eğitmen abi abla size yardımcı oldu mu bu problem de?

Kid.II.06: Evet oldu.

$R$ : Neler yaptı mesela eğitmen?

Kid.II.06: Mesela sorun ile ilgili ipuçları verdi. Yardım etti gibi.

\subsubsection{Consequences of coaching approach}

As a result of constructionist approach and the instructors' coaching strategies the children mentioned some learning outcome of the camp. Although, they cannot name it, they have explained very well their learning. Table 4.15 shows frequencies of subcategories emerged as results of coaching approach from both camps.

Table 4.15

Consequences of coaching approach

\begin{tabular}{llcccc}
\hline \multirow{2}{*}{ Category } & Sub-category & \multicolumn{2}{c}{ I. Camp } & \multicolumn{2}{c}{ II. Camp } \\
& & $\#$ & $\%$ & $\#$ & $\%$ \\
\hline \multirow{2}{*}{$\begin{array}{l}\text { Consequences } \\
\text { of coaching }\end{array}$} & Discovery learning & 9 & 30.0 & 1 & 4.5 \\
& Critical thinking & 3 & 10.0 & - & - \\
& Trial \& error & 8 & 26.7 & 1 & 4.5 \\
& Learning with fun & 3 & 10.0 & - & - \\
\hline
\end{tabular}

\subsection{Discovery learning}

Discovery learning refers to a type of learning where the students are exposed to particular experiences and questions in such a way that they "discover" for themselves the intended concepts (Hammer, 1997). According to Bruner, (1961) discovery learning could be benefited "(1) The increase in intellectual potency, (2) 
the shift from extrinsic to intrinsic rewards, (3) learning the heuristics of discovering, and (4) the aid to memory processing"(p. 58). Nine of the children expressed that they had discovered and constructed their knowledge. Kid.I.24 expressed the satisfaction and befits from the discovery learning as:

Kid.I.24: When you did like that I learnt how to make analogy and relationships between them. While days were passing I was learning more, I mean about robots, and I was relaxing because I was learning so in first days it was problematic for me.

R: Which one is good? Behaving like that or just telling on the board directly?

Kid.I.24: In my opinion, behaving like that because we set up the connection between them and we learnt better.

$R$ : So, what is happening when you set up yourself?

Kid.I.24: If you had shown on the board, maybe we could have forgotten it but for example at first when we make mistake and then fix it, I could remember this mistake longer however I am talking for me of course.

Kid.I.24: Sizin böyle yaptı̆̆ınızda mantık kurmayı anladım aralarındaki ilişkiyi anladım yani zaten ilk günler geçtikçe daha çok ögreniyordum ve yani robotla ilgili daha çok şey ögrendiğim için rahatllyordum o yüzden ilk günlerde sorun oldu yani

R: Böyle davranmamı mı iyi yoksa direk tahtada böyle anlatmamı mı daha iyi olurdu?

Kid.I.24: Bence böyle davranmanı çünkü kendimiz kurduk onunla arasındaki ilişkiyi yani daha çok anladık

R: Yani kendiniz kurunca ne oluyor?

Kid.I.24: Kendim yani direk tahtada gösterseydiniz siz belki unutabilirdik ama mesela biz ilk başta hata yapıp sonra düzelttiğimiz o hatayı daha çok aklımda kalıyor ben kendim için konuşuyorum

\subsection{Critical Thinking}

Critical thinking was defined as "an investigation whose purpose is to explore a situation, phenomenon, question, or problem to arrive at a hypothesis or conclusion about it that integrates all available information and can therefore be convincingly justified" (Kurfiss, 1988, p.20). Three of the children expressed that the camp has positive effects on grow of their critical thinking ability.

Kid.I.11: That is, we developed our mind. How is it called...

R: Knowledge? Skill?

Kid.I.11: Both it is

R: Or combination skills? 
Kid.I.11: Yes like it is. Still I am thinking. We can understand what to do better. For example, what could be for could be for collecting garbage? Could be hand and other things.

Kid.I.11: Yani başka zihnimizi şeyimizi geliştirdik. Ne denir.

R: Bilgilerini? Yeteneğini mi?

Kid.I.11: Hem o

R: Birleştirme becerilerini mi yoksa

Kid.I.11: Evet. Gibi. Yani daha iyi düşünüyorum. Ne yapacağımızı daha iyi düşünüyoruz. Mesela çöp toplamak amaçlı neler olabilir. El olabilir. Daha başka şeyler olabilir.

\subsection{Trial \& Error}

During the camps, children were encouraged to find the answers themselves. While working on activities or building their projects all instructors did not give the answers of their questions directly. They were supported to think on what they were making. That is children's learning were scaffolded which is a kind of supporting for the development and learning of children and young people (Rasmussen, 2001).

Sometimes the children figured out the problems and their solutions with trial-anderror. Eight of the children stated that they have learned with trial-and-error.

Kid.I.05: Good. Because now at first you cannot do anything but later everything, for example I could do the first one and it not it I could do the second so you really learn something. You learn something while passing from second to the third.

Kid.I.05: Güzel. Çünkü şimdi başta hiç bir şey yapamıyorsun. Ama sonradan her şey mesela ilk bi tanesini yaptım. O olmadı ikinciyi yaptım ondan ona geçerken bir şey öğreniyorsun. İkiden üçe geçerken bir şey öğreniyorsun.

Some of the children emphasized positive consequences of the trial-and-error learning.

$R$ : What do you think about that subject?

Kid.I.17: For me, finding with trying is better.

$R:$ Why it is better?

Kid.I.17: For instance, one instructor. When one thing was hard for us if he would say how to fix directly, we could not do it. We could see our mistakes. With trying and trying.

R: $O$ konuda neler düşünüyorsun.

Kid.I.17: Ya bence deneye deneye bulmak daha güzel.

R:Neden daha güzel. 
Kid.I.17: Mesela bir eğitmenimiz. Mesela bir konuda zorlandık. Hemen böyle yapın dese biz bir şey yapamazdık ki. Hatalarımızı görmüşs oluyoruz. Deneye deneye.

\subsection{Learning with fun}

The phrase "learning with fun" can be defined as a phenomenon in which the learner engage in a learning experience because the learner enjoy and value the process of the learning itself, rather than any instrumental reasons (Packer, 2006). It was observed that the children enjoyed being the camp and also they emphasized their enjoyment. Three of the children stated they experienced fun and learning during the camp both interviews and evaluation forms.

Kid.I.13: School sometimes could be boring. Here you learn something but having funny times.

Kid.I.13: Okul bazen sıkıcı oluyo. Burda bişeyleri öğreniyosun ama eğlenerek ögreniyosun.

Kid.I.UN:...It is nothing except for it and I could come here every day because it is very good to learn something with having fun.

Kid.I.UN: ...Onun haricinde yok ve ben burada çok güzel her gün olsun gelirim çünkü ĕglenerek bir şeyler öğrenmek çok güzel

\subsubsection{Instructors' Opinions about Coaching}

During the interview, one of the instructors stated how she worked on velocity concept with children. As she stated she preferred Socratic questioning to explore velocity concept and she adjusted pace of the station according to children needs.

For example, my topic was velocity. They should have done the equation; first of all we did with the robot and formed the equation. Later on I asked each one about what happens when the velocity increases and the way remains. Like that. I asked these kinds of questions to everyone and then one asked to another and another asked other one so they understood the topic well. Let's draw the graphic now and why did happened like that when we decrease the power and what happened to the velocity? They answered like it happened like that because there is a direct proportion and etc; at the end everyone answered. Even I asked to the Kid.II.18. I warned him that his friend is asking a question and wanted him to answer it. As a result I involved everyone to the group and I continued till I got the correct answer, and I told the topic entirely. Maybe, I went 
over something very fast and for something I was very slow because of the understanding level of the students. In my opinion, it was a good method because I think that they understood the velocity topic (Instructor 2).

Benim konum mesela hız konusuydu. Hız formülünü çıkartacaklar işte önce robotla yaptık formülünü çıkarttık. Daha sonra ben hepsine soru sordum tek tek hiz artarsa yol sabit kalırsa zaman ne olur? Gibi. O tarz sorular hepsine sira sıra sordum sonra bir ögrrenci diğer arkadaşlarına sordu o diğerine o diğerine sordu derken bayağı bir kavradılar. Hadi şimdi grafiği çizelim sizce niye böyle çıktı işte gücü azalttık hı ne oldu. Abla böyle oldu abla çünkü doğru orantı var abla ters orantı var gibi çünkü hepsine sordum ben tek tek. Kid.II.18 bile gelse gurubuma Kid.II.18'e de sordum. Kid.II.18 bak arkadaşın sana soruyor hadi bakalım nasıl yapmış diye. Yani herkesi guruba kattım ve herkesten de doğru cevaplar alana kadar soru sordum ben, o kadar uzunda anlattım. Belki bir şeyi çok hızlı geçtim bir şeyi çok daha yavaşlattırdım. Çünkü onların anlama düzeylerine göre anlayana kadar anlattım yani. Bence gayette iyi oldu hız konusunu anladıklarını düşünüyorum (Eğitmen 2).

\subsubsection{Conclusion about Coaching}

An instructor's duty in a robotic camp is becoming a good coach not a teacher or a group member to make activities with children. Therefore, they should monitor the children performance and give right amount of support when needed. Consequently, the children will learn better and they will enjoy their learning.

\subsubsection{Design principles for coaching}

Instructors' main duty at a robotics camps to be good coaches not to be classical teachers. Because of the theory behind robotics instruction, constructionism requires to children's learning from their own experiences with robots. Moreover the children stated that they have learnt better and they enjoyed their learning experiences with coaching.

A coach should motivate learners, analyze their performances, provide feedback and advice on the performances and how to learn about how to perform, and provoke reflection on and articulation of what was learned (Jonassen, 1999).

\subsubsection{Technical Issues}

During the camps, children had faced some technical problems, such as battery shortage, Lego pieces etc. During the first camp, it was observed that batteries of the 
robots could not stand all day and sometime children had to wait to charge their robots. At the second camp, extra battery packs were used, when a robot out of battery, that battery changed with charged one and the empty battery connected to charger. Therefore, the children should not have to wait charging of the battery. As seen at Table 4.16 which shows frequency of the technical issues from both camps, no child complained about battery shortage at the second camp.

Table 4.16

Technical issues

\begin{tabular}{llcccc}
\hline \multirow{2}{*}{ Category } & Sub-category & \multicolumn{2}{c}{ I. Camp } & \multicolumn{2}{c}{ II. Camp } \\
& & $\#$ & $\%$ & $\#$ & $\%$ \\
\hline \multirow{2}{*}{ Bechnical } & Battery shortage & 5 & 16.7 & - & - \\
Issues & Nattery charger & 3 & 10.0 & 1 & 4.5 \\
& Met enough pieces & 3 & 10.0 & 11 & 50.0 \\
& Unexpected behaviors & 3 & 10.0 & - & - \\
& Computer problems & 1 & 3.3 & - & - \\
\hline
\end{tabular}

Because of the camps were all day long, the most common technical problem was battery shortage. Although, the children warned to charge their robots at noon or at night when they leaving the camp, sometimes the batteries could not stand all day or sometimes the children forgot to charge them. Five of the children complained about battery shortage as a technical problem they faced.

Kid.I.23: We did not have any missing materials but we had a charge problem. It was because of us. Since, we forgot to charge it while having lunch.

Kid.I.23: Parçamı eksik kalmadı ama robotumuz şarjı falan bitiyordu. O bizden kaynaklanıyordu. Çünkü yemek yerken falan şarja takmayı unutuyorduk. O yüzden.

Moreover, three of the children from the first camp (they were at the same group) stated they had problems with battery charger. Because they had broken their battery charger; they have some troubles when they want to charge their robot. Only one boy 
stated the charger as a technical problem at the second camp, and they solved their problem borrowing from the other groups.

Kid.I.07: No, it did not.

$R$ : We did not have any problem.

Kid.I.07: Except the charger, there is not. The charger was broken.

$R$ : Was the charger broken?

Kid.I.07: We could not charge it. Except this, there was no problem.

Kid.I.07: Hayır olmadı da.

R: Olmadı herhangi bir probleminiz olmadı.

Kid.I.07: Şarj aleti dışında olmadı. Şarj aleti kırıldı.

$R$ : Şarj aleti kırlldı?

Kid.I.07: Şarj edemedik. Onun dışında bir şey olmadı.

Lego Mindstorms NXT Education set consist of 431 small pieces. These small lego pieces allow building what the children imagine such as arm to grab an object. While working on the robots sometimes, these pieces could not enough to build what they want to build. Therefore, when the children started to their projects, resource sets were distributed to them. Three of the children reported that from the first camp, basic robot set is not enough and they had deficiency of the pieces. Distribution of the resource sets was the solution to this problem.

R: Have you ever had any technical problem?

Kid.I.25: The materials were not enough, especially while doing the arm. For instance, we needed a two-part "l" shaped Lego but we could not find. We asked from another group but they also did not have.

R: We brought extra package. After that, did you still have problem?

Kid.I.25: After that, it started to be done. Because, we had used all the materials for the robot. However, we did not have for arm. After the extra materials, we did not have problem. We have done our job easily with the more materials.

R: Herhangi teknik bir problem ile karşılaştınız mı?

Kid.I.25: Parçalarımız yetersiz di. Kol yapmaya çalıştı̆̆ımız zaman. Çok yetersizdi. Mesela ikili le şekilinde bir lego artyoruz onu bulamıyoruz. Başka bir gruptan istiyoruz orada da yok.

R: Ekstra paket getirdik. Ondan sonra da mı olmadı.

Kid.I.25: Ondan sonra olmaya başladl. Çünkü robotta bütün malzemleri kullanmıştık. Kol için yapacağımız malzemler yoktu ama ek malzeme gelince pek zorlanma yaşamadık. Daha çok malzeme ile rahat bir iş yaptık. 
Until the children started to build their projects, the children worked with the NXT Education Set. When they started to their projects, the resource packs were distributed to the groups. With both sets, the groups have more than a thousand lego pieces. However, it seems that they were still not enough to satisfy children imagination. Like Kid.II.03, eleven children from the first camp stated that they had not enough pieces.

R: So, what can happen? You can have missing part of the robot. You can have missing part of the tool.

Kid.II.03: In fact, we had thought this robot Project like that; you know the mine workers, it is very hard for them and I would invent a robot that works in underground but we had no tool to dig.

$R$ : There were no tool to dig and you say this was something missing.

Kid.II.03: Yes.

R: Yani ne olabilir? Robotun parçası eksik olabilir. Yapacak aletinizin parçası eksik olabilir.

Kid.II.03: Biz aslinda bu robot projesini şöyle düşünmüş̧tüm. Hani maden iş̧̧ileri var ya. Onlara çok yazı oluyor. Öyle bir icat tasarlayacaktım da. Bu yeraltında çalı̧̧acaktı bu robot. Ama kazacak bir alet yoktu.

R: Kazacak bir alet yoktu. Bu bir eksiklik diyorsun dimi.

Kid.II.03: Evet.

Although, resource packs did not satisfied Kid.II.03, most of the children expressed that with the distribution of the resource pack their problem was solved.

Kid.II.11: Yes I had. It was at this Wednesday. We were looking for parts for our robot. Because we did not have, we wanted from XXX abi. He brought it to us. He brought a new box.

Kid.II.11: Evet. Oldu. Bu Çarşamba günü olmuştu. Biz robotumuz için parça arıyorduk. Parçamız olmadlğı için şey abiden istedik. XXX abiden istedik. O da getirdi bize. Yeni kutu getirdi.

At the second camp, children also stated that when they need a specific piece they had borrowed from other groups.

R: Ok, did you have any technical problem? For example, nonworking robot sensor etc... Missing parts etc...

Kid.II.02: When we had missing parts, we wanted from other groups.

$R$ : So, did you have any problem like they did not want to give it.

Kid.II.02: No. 
R: Peki teknik olarak herhangi bir problem ile karşılaştınız mı? Robot sensörü çalışmıyor olabilir. Parça eksik olabilir...

Kid.II.02: Parça eksik olduğunda başka gruplardan istedik.

R: Peki herhangi bir sorun oldu mu? Hayır, vermiyoruz gibi?

Kid.II.02: Yok hayır.

Lego Mindstorms NXT brick has $246 \mathrm{~KB}$ flash memory, when a program was written on the computer and then downloaded to brick; that program was occupied on the memory. Not only the programs, the sounds and pictures used in the program were also transferred to memory. Therefore, later the children should delete the old programs in memory, to open space for the new programs. Three of the children at the first camp complained about the memory deficiencies while working on the robots.

\section{R: Have you had a technical problem?}

Kid.I.17: what technical?

R: Start of the computer, missing materials, cut off electricity etc...

Kid.I.17: This kind of technical problem: we used the usb cable for two of them. We tried to send but it always gave error. It, for example, is a technical problem. It made us busy for ten-fifteen minutes.

R: Teknik bir problem yaşadınız mı?

Kid.I.17: Teknik derken.

R: Bilgisayarın açılmaması. Parçaların yetersiz gelmesi. Elektiriklerin kesilmesi. Kid.I.17: Şöyle bir teknik sorun. Usb kablosu mesela her ikisinide taklyorduk. Göndermeye çalışlyorduk. Ama hep "error" veriyordu. O mesela teknik bir sorun. On on beş dakika onunla uğraştık.

One of the children from the first camp complained about the robot's unexpected behaviors. He called the situation as "the robot losses its' mind".

$R$ : So, did you have any problem? The program may not work. The materials are not enough. The computer may not work.

Kid.I.11: The robot was getting mad time to time.

R: It is possible.

Kid.I.11: It is not. There is a problem. We had such a problem just a minute ago. XXX (one of the teacher) was also dealing. The teacher said to turn but it was not turning properly.

R: Peki teknik olarak bir sorun yaşadınız mı? Program çalışmayabilir. Parça yetersiz olabilir. Bilgisayar çalışmayabilir.

Kid.I.11: Arada bir robot kafayı yiyordu.

R: Olabilir.

Kid.I.11: Yemezde. Öyle bir problem var. Daha demin de öyle bir sorun yaşandl. XXX (eğitmenlerden biri) de bakıyordu. Daha dön gel diyor. Şöyle şöyle dönüyor. 
One of the children from the first camp stated that there was a problem with their computer, their computer was not responding while they were writing a problem and opens "error reporting" screen.

$R:$ So, did you have any technical problem? Your computer is not worked, the program is not worked.

Kid.I.28: Yes, our computers were not respond sometimes. All the programs did not respond. All the programs were deleted. We had such problems.

$R$ : So, Did not you save the program?

Kid.I.28: No, it was working without saving. While doing, it was not respond when we touch something. It gave error report.

R: Peki her hangi bir teknik program yaşadınız mı? Bilgisayarınız çalışmaz, program çalışmaz.

Kid.I.28: Evet.bazen bilgisayarımız kilitlendi. Bütün programlar kilitlendi. Bütün programlar silindi Onun gibi ve benzeri bazı sorunlar yaşadık.

R: Peki programı kaydetmediniz mi?

Kid.I.28: Hayır kaydetmeden oluyordu. Tam yaparken bir şeye dokunduğumuz zaman kilitleniyordu. Hata raporu veriyordu.

Two children from the second camp also complained about the problem on their computer. This problem was solved by using the one of the instructors' laptop.

Kid.II.22: We had some problems with the robot like it did not see all the lines on the ground and sometimes it did not see the flowerpot and pour it before see it. Moreover, at the beginning we decide to put on bulbs but we had some problems. For this reason we had used your computer.

Kid.II.22: Ya şimdi çünkü bizim bilgisayarda ışık sensörüne bi çizgiyi algıllyo algılamıyo sonra saksıyı görüyo görmeden döküyo falan gibi problemler oldu. Bi de önce lamba falan takıcaktık onlarda da problemler oldu. O yüzden sizin bilgisayarınız kullandık.

\subsubsection{Conclusion about technical issues}

Battery shortage, battery charger, not enough pieces, memory shortage and computer problems are main technical problems can be faced at a robotics camps. While design phase of a robotic camp, the designer should consider these problems and take precautions for them. Moreover, during the camp previously unseen technical problems can occur, therefore there should be person or at least one of the instructors could handle technical problems on time. If a technical problem could not be solved on time, that group who faced with technical problem could be complete the activity or could be behind of the other groups. 


\subsubsection{Design principles for technical issues}

At least one person should have enough technical competencies to solve technical problems at any of the problems occurrence. Sometime, it is impossible to solve technical problems on time; therefore it is advised to have an extra robot set and a computer. Also, it is advised that there should be extra battery packs. Therefore the children could not waste time waiting for charging. Moreover, a basic Mindstorms NXT set does not have enough pieces for a robotic camp, especially when the children design their robots at projects section, supporting each group with a resource pack is advised. If still a group needs extra pieces for their projects, the children should be encouraged sharing pieces.

\subsubsection{Challenges}

During the interviews, the children were asked about most challenging part of the camps or when have they been forced. Combining Lego pieces to create a functional part and programming sections of the camps seems the most challenging parts for the children. Table 4.17 presents frequency of challenges according to camps.

Table 4.17

Challenges

\begin{tabular}{llcccc}
\hline \multirow{2}{*}{ Category } & Sub-category & \multicolumn{2}{c}{ I. Camp } & \multicolumn{2}{c}{ II. Camp } \\
& & $\#$ & $\%$ & $\#$ & $\%$ \\
\hline \multirow{3}{*}{ Challenges } & Combining pieces & 14 & 46.7 & 2 & 9.1 \\
& Programming & 10 & 33.3 & 9 & 40.9 \\
& Sensors & 3 & 10.0 & - & - \\
& Gear station & - & - & 1 & 4.5 \\
\hline
\end{tabular}

The children have been forced mostly when they combining the pieces of the robots. It was observed that, it was easy to combine the pieces with the help of the manual, however when they create a new design especially while they work on their projects that was difficult to make a functional parts like can grabber. Fourteen of the children 
from the first camp and second children from the second camp stated that they had difficulties mostly when they combining the pieces.

\title{
$R:$ Ok, did have hard times?
}

Kid.I.12: I had hard times and also now I have.

$R$. Could you tell this more?

Kid.I.12: For example, we try to put the parts horizontally in order to take the cola can. It is very hard to put them. For two and a half day. It is hard for me till I started to do it. It is hard for me to put something horizontally. There is not a part and you have to create the fixing point. It is hard for me. Except for this, I have no problem.

\begin{abstract}
R: Peki zorlandı ̆̆ın zamanlar oldu mu?
Kid.I.12: Zorlandı̆̆ım zaman oldu şu anda öyle zorlanıyorum aşă̆ıda $R$ : Ne mesela anlatır misin bunu biraz daha.

Kid.I.12: Mesela aşağıda parçaları yatay takmaya çalıșıyoruz ya hani koka kola kutusunu almak için. Onu takmakta acayip zorlanıyoruz. İki buçuk gün. Yani onu başladığımdan beri yapmakta zorlanıyorum. Aslında baştan beri yapmakta zorlanıyorum. Hani yatay bir şeyler takmakta zorlanıyorum. Hani parça yok kendin oluşturacaksın takma yerlerini. O konuda zorlanıyorum. Onun dişında pek bir sorun yer yok.
\end{abstract}

$R:$ So, did you have any difficulty?

Kid.II.02: Yes.

$R:$ For example what? Could you give example?

Kid.II.02: For example, during the robot that we have created. Robot was moving but the arm was sticking and we had pulled it many times. Now we have completed it.

R: Peki zorlandı ̆̆ın zamanlar oldu mu?

Kid.II.02: Evet.

R: Mesela. Örnek verir misin? Neyde zorlandın?

Kid.II.02: Örneğin kendi yaptı̆̆ımız robotta... robot gidiyordu.. dönerken kol takılıyordu. Onu geri çektik. Çok oldu. Sonra şimdi tam yaptık.

Although one of the important outcomes of the camp for the children was learning programming of the robots with NXT-G software, some of the children had hard times with the programming of the robots. Ten of the children at the first camp stated that programming was challenging for them.

$R$ : Ok, did you have anything hard for you to do during the camp?

Kid.I.11: I have sometimes. About programming. I am very confused.

R: Peki zorlandı̆̆ın zamanlar oldu mu kampta.

Kid.I.11: Bazen oluyor. Programlamakta. İyice kafam karlşıyor. 
The children were instructed how to program their robots at first three days of the second camp. The instructor had chance to explain more advance concept at the second camp. The researcher has observed and noted that:

At the programming part I did not tell so easy things. I even told about "Wire". In my opinion, kids take how much it is given to them, if they are curios.

Programlama da hiç de basit şeyler yaptırmadım. "Wire” bile anlattım. Bence çocuklar ne kadar verilirse o kadarını allyorlar, yeter ki istekli olsunlar.

However, nine of the children at the second camp stated that they had difficulties at programming of the robots especially while building their projects. Moreover, it was observed that some of the children could not applied what they had learned about programming when they working on the projects.

$R:$ So, did you have hard times?

Kid.II.03: While programming.

$R$ : According to you, why was it hard for you? What could be the reason; do you think you could not get the logic behind it?

Kid.II.03: In fact, I got the programs but I forgot easily.

R: Peki zorlandı̆̆ın zamanlar oldu mu?

Kid.II.03: Programlarken.

R: Peki neden zorlandığını düşünüyorsun? Ne olabilir mesela mantığını kavrayamadığını mı düşünüyorsun?

Kid.II.03: Ya da ben şöyle yani. Programları anladım aslında da. Çabuk unuttum. O yüzden.

Similarly programming was reflected in the evaluation forms:

Kid.I.03: We learnt how to design a robot to gather garbage that is collecting garbage and putting somewhere else. We designed his robot (even it was hard) and then we started to program it.

Kid.I.03: Bir robotun çöp toplaması için yani çöpleri alıp belirli bir yere koyması için robotu tasarlamay öğrendik. Bu robotu tasarladık (zor da olsa) sonra programlamaya başladık. Bu benim için daha zor oldu.

Moreover, three of the children stated that they had slogged when working with sensors.

$R:$ Did you have hard times?

Kid.I.15: Yes, I did. Sometimes ultrasonic sensor did not see and we were very busy with and then it started to see. 
$R:$ Zorlandiğın zamanlar oldu mu?

Kid.I.15: Evet oldu. Bazen ultrasonic sensör görmedi. Ve onunla çok uğraştıktan sonra sonunda görmeye başladı.

Kid.II.05 stated that he had difficulties to understand the gear station because he had not learned the subjects at school yet.

R: So, did you have difficult times during the camp?

Kid.II.05: Yes. For example during the first days, they had given us something. It was about cogwheel. Instructor XXX had prepared it. It was very hard at this day because we had not learnt cogwheels yet. It is taught at 7 th grade. I was just at 7 th grade and it was very hard for me.

R: Peki zorlandı̆̆ın zamanlar oldu mu kampta?

Kid.II.05: Evet. Mesela ilk gün bir şeyler vermişlerdi. Dişli çarklar ile ilgili idi. XXX abi hazırlamıştı. Ya o gün çok zorlamıştı. Çünkü biz öğrenmemiştik çarkları. Yedinci sınıfta öğreniyorlar. Bende yediye geçmiştim. O beni çok zorlamıştı.

Students' data revealed "combining Lego pieces" which refers to mechanical part of the robots and "programming" are two important challenging issues in a robotics camp.

\subsubsection{Instructors' opinions about challenges}

Although programming seems common difficulties of both camps for children, the instructors stated that the children were very good at and enjoyed programming.

R: We have mentioned about the stations, what about the programming part?

Instructor 1: In my opinion, it was very good.

$R$ : However, were they tired?

Instructor 4: Sometimes they were tired but they liked very much and it was funny for them.

Instructor 2: All of them did.

Instructor 1: Kid.II.05 and others were very good at it.

R: İstasyonları konuştuk programlama kısmı?

Eğitmen 1: Bence çok güzeldi.

$R$ : Çok mu yoruldular diyeceğim ama

Eğitmen 4: Yorulduklarl da oldu ama çok sevdiler çok zevk aldılar.

Eğitmen 2: Hepsi yaptı yani

Eğitmen 1: Kid.II.05 falan çok iyiydi. 


\subsubsection{Conclusion about challenges}

The most challenging parts of the camps were programming and combining pieces. Therefore the instructors should be more supportive and be watchful when the children working on programming or combining Lego pieces. Moreover, nearly all of the children had not programming experience; therefore transition to programming should be smoothed with some activities like role playing.

\subsubsection{Design principles for challenges}

Challenges should be part of a robotics camp, because the challenges will increase motivation and engagement on the activities (Nourbakhsh et al., 2004). However, the challenges should not be too hard for the children to result in frustration. Because nearly all of the children will not have programming experience, programming will be challenging it selves. Moreover, getting used to the pieces and connecting these pieces to create functional parts requires time and some mechanical talents. Especially first days of the camp, combining pieces also could be frustrating, therefore the instructors should support required amount of scaffolding, not too much or less.

\subsubsection{Camp duration}

Both of the camps generally started around 08:45 and finished around 16:00. During an ordinary camp day, one long lunch break, two snack breaks and three or four short breaks were given. A study session was 45-60 minutes long. Length of a study sessions mostly arranged to preparation of lunch and snacks.

During the first camp, the children did not complain about camp schedule, even at the camp evaluation forms. However, during the second camp it was observed that some of the children did not go out at breaks and continued to work on robots, but many of the children unwillingly came back to their work after a break. Moreover, they asked for more and long breaks during the camp and they reflected their request at the camp evaluation forms.

Kid.II.19: Breaks are VERY SHORT and FEW (written as capital letters) 
Therefore, the researcher added camp duration related questions to the interview schedule. As a result, camp duration category could emerge only at the second camp interviews and camp evaluation forms. Table 4.18 represents the frequencies of camp duration related sub-categories from the interviews and camp evaluation forms for the second camp. Camp duration related complaints are categorized at three subcategories.

Table 4.18

Camp duration

\begin{tabular}{|c|c|c|c|}
\hline \multirow{2}{*}{ Category } & \multirow{2}{*}{ Sub-category } & \multicolumn{2}{|c|}{ II. Camp } \\
\hline & & \# & $\%$ \\
\hline \multirow{3}{*}{ Camp duration } & Too long & 5 & 22.7 \\
\hline & Breaks are too short & 5 & 22.7 \\
\hline & Number of breaks & 5 & 22.7 \\
\hline
\end{tabular}

Five of the children stated that the camp duration from 8:40 to 15:00 were too long. According to them camp duration should be shorten.

$R:$ For example, at which part you are bored?

Kid.II.13: Not at the morning but at afternoon I am bored.

$R$ : Is the camp duration very long for you?

Kid.II.13: Yes.

$R$ : So, what should be the duration?

Kid.II.13: Camp duration is I think seven hours and it could be less. I think that $i$ wish it was five or six hours.

$R:$ Mesela nelerde siklliyorsun?

Kid.II.13: Illk geldiğimde ilk dediğim yani sabah geldiğimde değil de böyle öğleden sonra siklliyorum.

R: Şey süre uzun mu geliyor yoksa kamp süresi?

Kid.II.13: Evet.

R: Peki nasil olsun kamp süresi?

Kid.II.13:Kamp süresi böyle hani yedi saat herhalde böyle. Yedi sekiz saat altıda olabilir. Beş altı saat olsa diyorum okul kadar. 
Although, according to first camp the duration of the breaks were longer at the second camp; the children complained about the shortness of the breaks. According to five of the children, the breaks were too shorts.

$R:$ Do you want to add or share something about the camp?

Kid.II.05: I want you to extend the breaks.

R: Peki senin eklemek istediğin kampla ilgili paylaşmak istediğin bir şey var mı?

Kid.II.05: Teneffüsleri uzatın diyorum.

Moreover five of them also complained number of the break times.

R: While talking about breaks, do you mean the duration or the number of breaks.

Kid.II.15: Number of it.

R: Number.

Kid.II.15: We have three breaks.

$R$ : Yes, we have three big breaks, do you prefer more breaks with lower durations?

Kid.II.15: It would be better for me.

R: Şey ara çok az derken aranın süresi mi çok az, yoksa aranın sayısı mı çok az yani?

Kid.II.15: Sayıst.

R: Sayısı.

Kid.II.15: Üç ara yapıyoruz zaten.

$R$ : Evet üç tane büyük ara yapıyoruz onun yerine kısa kısa daha fazla mı ara yapalım?

Kid.II.15: Öyle yapalım öyle daha iyi olurdu bence.

\subsubsection{Instructor's opinions about camp duration}

The second camp was more exhaustive than the first camp because of the hot weather. The second camp was conducted at hot summer times in Ankara and there was not any air-conditioner at camp area. The researcher noted that:

Hot weather is another problem because we cover the window with curtain and make the presentation. Atmosphere is like burning. We open it immediately when we do not make presentation but it is useless. It is very hot.

Sicaklar da ayr bir sorun, pencereyi perde ile kapatıp, projeksiyon ile sunum yapıyoruz. Ortam yanıyor. Projeksiyon kullanmadığımız anlarda hemen açıyoruz ama nafile. Çok sıcak. 
Therefore, the instructors kept breaks longer than the first camp. The researcher noted his thoughts as:

As the instructors we even want to make long breaks because we are tired and bored. It is very tiring doing like that from morning to the evening. Hot weather is also another thing.

Ĕgitmenler olarak bizler bile araları uzun tutmak istiyoruz, sikıllyoruz, yoruluyoruz. Bu şekilde, sabahtan akşama kadar çok yorucu. Sıcaklar da cabası.

During the camp, some of the instructors mentioned that why the camp was day long, the camp should be half day long.

Some of the kids were telling about the long camp duration. As the instructors, we are very tired. As my personal opinion, camp should be in half of the day (Instructor 4).

Çocuklardan bazıları da kamp süresinin uzun olduğunu söylüyor. Eğitmenler olarak bizler de çok yoruluyoruz. Benim de şahsi fikrim yarım gün olmalı kamp (Ĕ̈itmen 4).

Moreover, during the focus group interview the instructors summarized the all issued about camp duration and conditions.

Instructor 1: First of all, it should be till the noon.

R: We had never talked about it.

Instructor 1: I think because all of us are thinking the same thing. It should be till noon, full day is waste of the time.

Instructor 4: I talked to some of the kids about whether the half day would be better and they said that full day is better.

Instructor 3: They think like that because they only had full day work.

Instructor 1: In my opinion, they are not aware of it; they do not come back before one hour when they exit

$\ldots$

Instructor 4: These camps should not be in the summer.

Instructor 1: There were some students who wrote and wanted air conditioner on the rooms. They do not want to go out much.

Instructor 2: Yes, there should be air conditioner.

Eğitmen 1: Bir kere fixiz öğlene kadar olmall.

R: Onu hiç konuşmadık sizlerle.

Eğitmen 1: Hepimizin fikri aynı diye konuşmadık herhalde. Öğlene kadar olmalı tüm gün zaman kaybl.

Eğitmen 4: Bir kaç çocukla konuştum öğlene kadar olsa daha mı iyi olur diye yok hocam bütün gün olsun işte. 
Eğitmen 3: Ama bütün günü gördükleri için bütün gün olsun istiyorlar.

Eğitmen 1: Onlar farkında değiller bence zaten çıkınca bir saat gelmiyorlar.

Eğitmen 4: Yazın olmasın böyle kamplar

Eğitmen 1: Şey yazanlar vardı klima olsun odalarda evet evet klima isteyenler vardı. Dışarı çıkma istekleri de azalıyor.

Eğitmen 2: Klima evet olsun ya.

\subsubsection{Conclusion about camp duration}

The first camp was conducted at winter and there was not any complaint about camp duration or break times, however, the children and the instructors were agreed that the second camp was more exhaustive because of the hot weather. The hot weather condition was affected the children and the instructor attitudes toward the camp. Therefore, while designing a robotics camps, the designer should consider weather conditions. Moreover, for an effective robotics camp physical conditions of the camp area should be suitable for effective instruction.

\subsubsection{Design principles for camp duration}

A normal day for a robotics camp could be arranged as a forty-five or fifty minutes study section and ten minutes break. After three study sections, a long lunch break could be given. Similarly, three study sections could be done at afternoon.

While designing a camp curriculum, physical conditions that affect the quality of the instruction like the weather condition also should be considered. If the camp were conducted at hot summer times, the air-conditioner for camp area is advised. If airconditioner is not available, the camp duration should be shorter and break times could be longer to prevent the children get bored.

\subsubsection{Summary and design principles}

The results of the study are presented in this chapter. Firstly, both robotics camps' diaries are presented to better understanding. Then emerged categories from analysis of the interviews, observations, camp evaluation forms and field notes are presented. After the presentation of each category, design principles for a robotics camp are expressed. Robotics camp design principles were created by the researcher considering the results of the study and the researcher's experiences. These design principles are consolidated at Table 4.19. 
Table 4.19

Design principles for an educational robotics training camp

Category Design principles

Robotics concepts instructions could be design under four heading, general robotics knowledge, programming, sensors and mechanics.

"General robotics knowledge" which is covering general idea of what robots are could be presented at the beginning of the camp with interesting activities like videos, drawing pictures, role playing games and guiding questions.

Programming, sensors and mechanic concepts should be given Robotics concurrently.

The content of the instruction at a robotics camps, should be organized from simple to complex and subsequent content should be integrated with former one.

Three days and six hours a day programming instruction is quite enough to introduce NXT Mindstorms sets and teach NXT-G programming environments with advanced panel and necessary practices.

Mathematics and science concepts should not be given with direct instruction at a robotics camps. Problem Based Learning approach

Mathematics could be used.

\& science Mathematics and science activities should be prepared for affecting the children's attitudes toward mathematics and science in a positive way. 
Table 4.19 (continued)

Some complex problems like real life should be prepared and the children should use their mathematics and science knowledge to Mathematics solve that complex problem by using robots.

\& science Robotics training camps should give chance to practice to the children what they have learned at schools.

At least one science instructor should attend to a robotic camp.

Peer learning or more social outcome can be encouraged with less involved instructors but in less managed environment.

In group and between groups social interaction should be encouraged in a robotic training camp. Implementing cooperative

Social skills learning and small group work strategies could enhance in group interaction

Between groups interaction could be enhanced borrowing Lego pieces, sharing information or arranging competition between the groups.

Projects parts should be emphasized, if it is possible whole camps

Camp's components curriculum should made of small projects including STEM concepts.

STEM related concepts could be studied at learning stations and activity sheets could be used at these stations.

A guest who has robotic career could be invited to discuss career

Career options with children, female guest advised because she also could be a role model for the girls. 
Table 4.19 (continued)

The group size should be arranged that every child in the group should have duties at any time. If any group member does not have a work to do, they find unrelated something to engage.

Group size Engagement of all group members with activities could be ensured by adjusting group size or complexity of activities.

For the activities similar to activities used in these camps, three member groups are advised, four members group also acceptable.

\begin{tabular}{ll}
$\begin{array}{ll}\text { Group mates' } \\
\text { gender }\end{array}$ & Groups should be constructed with mixed gender. \\
\hline & Task sharing and division of labor should be encouraged to \\
Group & eliminate "not interested" and "wants to make more" group \\
problems & problems.
\end{tabular}

The children who attended to camp should be at the same level.

Tournaments and races should be arranged to increase motivation and to make the camp more entertaining.

Competition Competition should not be over emphasized and causes to misunderstandings. It should be clearly defined that tournaments and races are just for fun and motivation and the children should not predicate another meaning to the results of the competitions.

Instructors' main duty at a robotics camps to be good coaches not to be classical teachers.

Coaching Instructors should motivate learners, analyze their performances, provide feedback and advice on the performances and how to learn about how to perform, and provoke reflection on and articulation of what was learned (Jonassen, 1999). 
Table 4.19 (continued)

Battery shortage, battery charger, not enough pieces, memory shortage and computer problems are main technical problems can be faced at a robotics camps.

Technical There should be at least one person has enough technical issues competencies to solve technical problems at any of the problems occurrence.

There should be extra robot set, computer and battery packs.

A basic Mindstorms NXT set does not have enough pieces, supporting each group with a resource pack is advised.

Challenges should be part of a robotics camp, because the challenges will increase motivation and engagement (Nourbakhsh et al., 2004).

The challenges should not be too hard for the children to result in frustration.

Challenges

Because the children will not have programming experience, programming will be challenging it selves. Moreover, connecting Lego pieces to create functional parts requires time and some mechanical talents. Therefore, especially at the first days of the camps, the instructors should support required amount of scaffolding, not too much or less.

A normal day for a robotics camp could be arranged as a forty-five or fifty minutes study section and ten minutes break. Three morning and three afternoon sessions with lunch break could be

Camp duration done.

While designing a camp curriculum, conditions that affect instruction should be considered and precautions should be taken like weather condition. 


\section{CHAPTER 5}

\section{DISCUSSION AND CONCLUSION}

This chapter presents the discussion on the findings of the research study. More specifically, it covers the discussion on the design principles for educational robotics training camps. First, each theme and category which was presented in the findings of the study chapter is discussed deeply in the same order. Then, after the discussion of each theme and category, the researcher makes suggestions for a successful educational robotics training camp. Next, a robotics camp design guideline is presented. Lastly, implications of the findings and recommendations for future research are presented. For better visualization of the themes, categories, and their relations; concept map of themes and categories is presented again at Figure 5.1. Simply, the driving research question; the key design principles for an educational robotics training camp is centered on the diagram and each main and sub design issue is placed around the research question and their relation with the research question is shown with lines. Discussions in this chapter have been organized according to the diagram. 


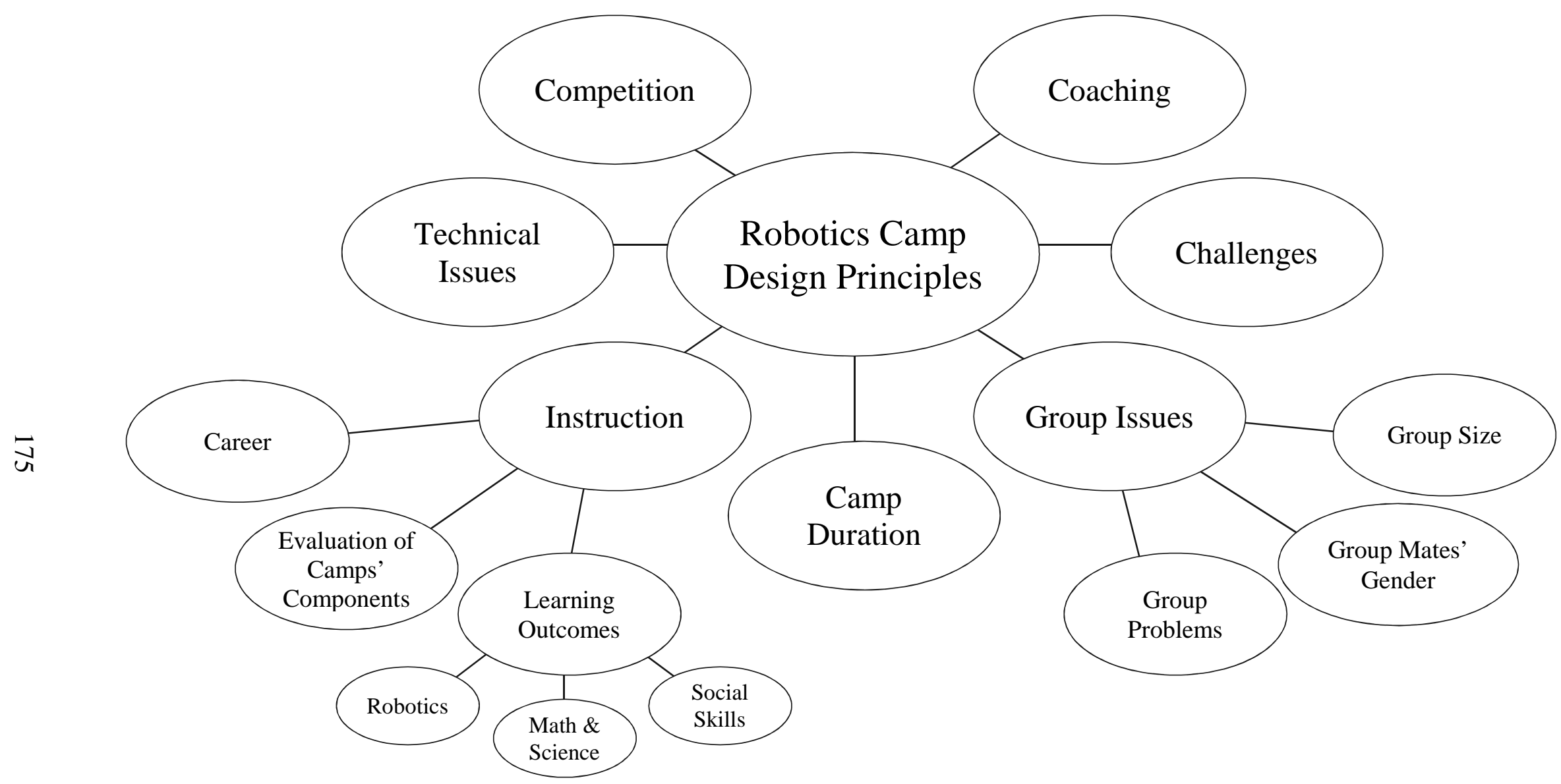

Figure 5.1 Concept map of the themes and categories 


\subsection{Discussions on Instruction}

The first and the most important sub question of the study is how the instruction should be structured in a robotics training camp. To answer this sub question, firstly learning outcomes of the camps were investigated. Secondly, each part of the both camps was evaluated and lastly, career effects of the camps were discussed.

\subsubsection{Learning outcomes}

Results of the study have shown that learning outcomes emerged at three categories which are "robotics", "mathematics and science" and "social skills".

\subsubsection{Robotics}

For a robotic training camp, it is obvious that firstly children should know how to build and program the robots then they could use the robots in the activities. As a result of the study, robotics knowledge can be categorized as "general robotics knowledge", "robot mechanics", "programming" and "sensors". As Nourbakhsh et al., (2004) emphasized that a robotic course should certainly include common aspects of all robots mechanics and programming. The answer of how the instruction should be structured could not be given without clearly defining how robotics instruction should be structured. Therefore, robotics instruction discussed under four headings as presented in the findings of the study chapter.

\subsection{General robotics knowledge}

The first learning outcome category under "robotics" theme is general robotics knowledge and it refers to general information about robots such as what robot is, why we use robots etc. The results of the study have shown that the children have gained knowledge about robotics from camps. However, while designing robotics camps, the question is when and how robotics knowledge should be given to the children.

Because of the paradigm shift from teacher-centered instruction to learner-centered instruction, Reigeluth (1999) offered elaboration theory which argues that content should be organized from simple to complex order. Elaboration theory provides 
holistic approach to foster learning process more meaningful and motivational. According to the theory, broader, more inclusive concepts should be taught before the narrower and more detailed concepts. The theory of robotics studies can be based on Papert's constructionism (1993), which also emphasizes children's active roles while building their own intellectual structures. In addition, Reigeluth's (1999) elaboration theory emerged from needs for ways to sequence instruction for learnercentered paradigm. Therefore, elaboration theory may fit well to robotics camp design. When all concepts in a robotics camp curriculum considered, the basic, the broadest and the most inclusive concept is the definition of a robot that is general robotics knowledge. When elaboration theory considered, instruction of a robotics camps should start with general robotics knowledge.

Because of the limited studies related to robotics camp curriculum, it is hard to find any evidence about starting robotics camp with general robotics knowledge. In addition, the studies presenting their camp curriculum is also limited. However, Murphy and Rosenblatt's (2000) presented their "robocamp" curriculum at their article. After an introduction part, their robotics camp starts with instructor-led discussions about what can robots do and continues with mini lecture about parts of a robot. Although, they did not provide direct suggestion on starting robotics camp with general robotics knowledge; their approach to instruction at robotics camp is alluding instruction should start with basic robotics.

General robotics knowledge should not be given by direct instruction. The content should be given by interesting activities which should allow children to create their meaning about robots as constructionism stated.

\subsection{Robot mechanics}

Nourbakhsh et al. (2004) defined mechanics as "interrelationship between various kinematics substructures of the robot and the kinematics of the overall robot" (p.1). They conducted their study with "Trikebot" which is quite different than LEGO Mindstorms NXT and their mechanics category includes basic mechanisms like servos, motors, chassis, suspension, bearings and electronics like motor controllers, microprocessors, the vision system etc. However, LEGO Mindstorms NXT sets were 
used in this study and the children did not deal with any electronic components of the robots. Therefore, robot mechanics refer to combining Lego pieces to build functional robots for this study.

In both camps, Lego Mindstorms NXT sets were distributed to the children and they were given chance to investigate the pieces, then they discussed for five or ten minutes about the main parts of the robots. The children have learned how to build robots while they were building their first robots according to the instructions on the manual at the first camp and simpler base robot (Appendix K) at the second camp. That is, they have learned robot mechanic by building a robot like Papert's simple definition of the constructionism as "learning by making" (Papert \& Harel, 1991). While they were building their robots, the instructors just explained the symbols on the manual because the manual was in English and they helped the children when they had problems.

Results of the study have proved that, robot mechanic emerged as one of the learning outcome of robotics camps. Nourbakhsh et al. $(2004,2005)$ and Druin \& Hendler, (2000) have found similar result and Nourbakhsh et al. $(2004,2005)$ called that theme "mechanics" and Druin and Hendler (2000) called "mechanical design".

As presented in the findings chapter, the frequency of "robot mechanics" was not high as much as programming and sensors categories. The children did not take instruction about robot mechanics like programming and sensors, moreover; they just followed instruction either from the manual or Appendix K. Not taking any formal instruction should be the reason of why frequency of "robot mechanics" is lesser than programming and sensors. The children could not think that robot mechanics is one of the subjects they have learnt at the camps, because they could already combine Lego pieces.

The results of the study have also shown that "combining pieces", it can be also called "robot mechanics", was the most challenging activity of the first camp. However, combining pieces nearly disappeared as a challenging activity at the second camp. That can be explained by preparing a simpler robot design handout (Appendix K) and using that design as the first robot building activity before than the 
design at the manual. Therefore, the children started to the mechanic concepts with much simpler concepts like elaboration theory stated. In addition to the simple robot design, the children also built a robot according to the manual at the second camp. Therefore, the children at the second camp had chance to build one more robot than the children who attended to the first camps. It can be concluded that, preparing a simpler robot design is better approach for robot mechanic concepts and it is advised for more effective robotics camp curriculum.

\subsection{Programming}

The most important outcome is that children can start to make program and learn how to program their robots. Although programming could be very challenging for at that age of children in classical programming environments such as Basic or Pascal, NXT-G programming environment make programming understandable for the children because of drag and drop blocks architecture. That feature of NXT-G environment enhance the understanding of programming logic rather than spending hours and days to learn and debugging the various syntaxes for first-time programmers (Ranganathan et al., 2008).

Robots have unique characteristics for teaching programming because when children make a program, the results or outcomes of the program is not on a computer screen, but, outcomes occur at the children's real world, not in virtual computer world. "The programmable brick breaks new ground for programming environments for kids: it connects programming to the real world..." (Sargent, 1995, p.11). That could be the reason for why programing was totally most cited learning outcomes of both camps.

Although, elementary school children are not required to know programming at that age, programming is related to problem solving and critical thinking abilities. There are many research with different age of children presenting that programming with robots positively affected critical thinking and problem solving skills (Chambers, Carbonaro, \& Rex, 2007; Cocek, 2008; Druin \& Hendler, 2000; Murphy \& Rosenblatt, 2000; Ranganathan et al., 2008; Scott, 2009; Sullivan, 2008). Moreover, Papert (1993) goes far more beyond than critical thinking and problem solving. According to him, learning programming is learning of how to communicate with a 
computer and that could change the way they learn everything else such as mathematics.

Because programming part of robotics camps are very important, programming instruction should be designed carefully. Although, it is impossible to point best way for programming instruction with two robotics camps experience, comparisons of the two camps results can reveal the better instructional approach for programming. Results of the study have shown that the second camp was better than the first one in terms of teaching programming. The main difference between the two camps was programming instruction was given together with science and mathematics activities at the first camp however, the first three days of the camp was reserved for only programming at the second camp. Although the contents of programming instructions were similar, just focusing programing at the first three day could be the reason for better understanding of programming. Therefore, it is better to separate science and mathematics activities from programming instruction. Moreover, because of robots' motivational effect (Korchnoy \& Verner, 2008; Petre \& Price, 2004; Vollstedt, 2005; Zubrowski, 2002), dealing with only robots during the first days of the camp may motivate the participants toward the camp. Also, as explained before, according to elaboration theory, firstly learning robots mechanics and programming then using robots at science and mathematics activities will be more productive. Because learning robot programming is simpler phase than using robots in mathematics and science activities.

Moreover, the results of the study have also shown that, the children mostly struggled with programming and combining pieces. Nourbakhsh et al., (2004; 2005) also reported that the children were mostly struggled programming and mechanics. Although, simple programming architecture of NXT-G environments, they could be struggled with algorithm of the programming because nearly all of the children have not written a program before. That implies that, some algorithm activities could be added to robotics camp curriculum before starting programming instruction. Algorithm activities should be thought as the first step for programming, therefore these activities should be as simple and basic as possible. Moreover, like the whole camp curriculum, the programming section should be constructed from simple to complex in itself. After simple algorithm exercises, basic blocks such as "move", 
"sound" and "display" should be thought. Later, intermediate block like "wait for" and the logical blocks like "loop" and "switch" should be given. If it is required, advanced panel of NXT-G environment could be given lastly. In addition, the instructors should be aware that children struggle mostly programming and combining Lego pieces. Therefore, the instructors should be more watchful when children working on programming or combining pieces.

\subsection{Sensors}

Robots can interact with their environments by their sensors and NXT sets come with four basic sensors, ultrasonic, light, sound and touch. During the camps, the children worked with these sensors. Nourbakhsh et al., (2004; 2005) placed sensors under mechanics theme. According to them, sensor is one of the electronic components of a robot. However, sensors emerge as a learning theme in this study and sensor concept was the second most cited robotics learning outcomes of both camps.

One of the themes from Nourbakhsh et al., (2004; 2005) studies is "robot point of view" which refers to "the ability to "see" through the robot's eyes and thus understand the sensor limitations and action constraints under which the robot must operate" (p.20). That emphasize children understandings of how robots can perceive through their sensors and it is related to critical thinking skills of the children. In addition, Murphy and Rosenblatt, (2000) prepared an activity called "through the eyes of a robot" and focused sensors of a robot. Although, there was not emerged any category as robot point of view in this study, sensor category under learning outcomes also includes robot point of view. When a sensor is connected to a robot, it requires a program to work in intended way. Especially, making a program for a sensor requires children have already internalized how a robot perceive their environment (robot point of view) with that sensor.

Using sensor is not just related to connecting a sensor in an appropriate way (mechanics); it is also related to analyzing, decision making and problem solving. When children asked to design a robot with specific purpose, for example garbage collector robots were designed in this study. The children should analyze the problems, such as how robot can grab a can and how to prevent robots passing the 
borders etc. After that, they should decide which sensors should be used and how these sensors will trigger an action. After the first trial, mostly they face with problems required to be solved. This continuum analyzing the emerged problems, deciding solutions and solving problems continue until the robot works fine.

During the camps, the children could work only with four sensors. However, there are much different external sensors in the market for NXT sets such as $\mathrm{pH}$, gravity, accelerometer, force etc. Conducting a robotic camp with these sensors will make the camp more colorful and enjoyable. Much more science activities can be designed with these sensors and the children also could use these sensors in their projects.

\subsubsection{Mathematics \& science or STEM (science, technology, engineering and mathematics)}

During the design phase of the camps, mathematics and science concepts were emphasized. The sixth grade "Mathematics" and "Science and Technology" courses' curriculums were investigated and suitable concepts for robotics activities were decided. However, engineering field was not considered so deeply. Although similar courses given to children at schools as stated in the literature chapter; the STEM (Science, Technology, Engineering and Mathematics) concepts and these four subjects are not thought together in Turkey. Engineering courses are not included in elementary school's curriculum and these courses are thought separated. Therefore, at the design phase, the instructors are just focused on science and mathematics activities. However, the robot itself could be thought directly related with technology and engineering.

When the STEM (Science and Technology, Mathematics and Technology \& Design courses in Turkey) curricula are investigated, it could be seen that vision of these courses are to give questioning, critical thinking, and problem solving skills to children (TTKB, 2006a, 2006b, 2009). There are many robotic studies in the literature aimed to measure effects of robotics activities on these skills (Barak \& Zadok, 2007; Barker \& Ansorge, 2007; Beer, Chiel, \& Drushel, 1999; Hussain, Lindh, \& Shukur, 2006; Johnson, 2003; Lindh \& Holgersson, 2007; Mauch, 2001; Mosley \& Kline, 2006; Nugent, Barker, \& Grandgenett, 2010; Robinson, 2005; 
Sullivan, 2008; Wyeth, Venz \& Wyeth, 2004). Results of the study also revealed that robotic activities have positive effects on children's discovery learning and critical thinking skills because robotic activities give children to use questioning, critical thinking and problem solving skills. It is obvious that a robot is a good tool not only of robotics itself, but also for general science, technology, engineering, and mathematics (STEM) concepts (Mataric et al., 2007).

The study has shown that the camps reinforced children's interest toward mathematics and science, as consequences of the science and mathematics activities or learning stations. However, when the instructors criticized the STEM education at both camps; they admitted that the robot and STEM relation could be better. That is, robots could be used more effectively for STEM concepts. Moreover, they emphasized that in a robotic camp, STEM concepts should not be given as instruction, the children should be in a complex problem solving process and they should use their prior knowledge to produce solutions for that problem. Futschek (1995) suggested similar approach to technology education. In the technology content, children can solve open-ended problems on the basis of their own needs and what is meaningful and significant to them. Regardless of the media, pupils are encouraged to work and learn in a way that fosters creativity and discovery (cited in Järvinen, 1998). As given before, for example the children could be asked to design the fastest robot. While designing, children have chance to use their creativity. Also, they should consider effects of such as gears, number of the motors, and radius of the tires. The activity could be finished with a discussion on effects of these variables on robots' speed, guided by the science teacher.

Activities make the connection between robots and the STEM concepts. Therefore, while the activities are being prepared, instructors should consider target group characteristics and their prior knowledge while designing camp curriculum. It would be better to add one science and technology teacher and one mathematics teacher who had experience with target group to the camp team. Moreover, these teachers also could create and manage discussions about the concepts after the activities. 


\subsubsection{Social skills}

In addition to "robotics" and "STEM" outcomes, robotics also has impact on children's social skills. Social learning is one of the learning outcomes, may be the most beneficial one of robotics studies and this subject has been worked since Logo which is ancestor of today's Lego Mindstorms NXTs (Yelland, 1995a). Some of the studies focused on types of interactions inside the groups (Denis \& Hubert, 2001), some of them resulted as robotics helps children developing teamwork skills (Johnson, 2003) and the learning is more fun at environments that allows social interaction (Panadero, Román, \& Kloos, 2010; Robinson, 2005). This study also resulted in similar way; children gain some social skills such as group working. However, the aim of the study was not to deeply investigate social interaction patterns or teamwork skills the children developed during a robotics camp. The aim of the study was to reveal how social skills could be empowered during a robotics camp and suggesting strategies for it.

The result of the study is quite interesting at social skills category. When both camps are compared according to emerged social skills, the first camp is richer than the second camp. The reasons of difference can be found when the both camps are compared on their social potentials. Firstly, the number of the children who attended to the first camp was more than the second camp. Because of the equal number of the robot sets, the number of the children at each group was more at the first camp. Therefore, the first camp provided much richer social environment to the children. Secondly, number of the instructors who attended to the second camp was more than the first camp and each group had an instructor at the second camp. Therefore, the instructors could direct the children to activities when they lost their attention and interfere any unwanted situation. As a result, the classroom management was much easier and the camp area was more noiseless at the second camp. Therefore, the children could work much quieter but lesser social environment. Lastly, competition was kept at minimum level at the second camp. Competitions also have social values and competition and social interaction are key issues to increase children's motivation (Panadero et al., 2010). Keeping competition at minimum level at the second camp could be another reason for the difference between the camps. 
Competition is discussed later in this chapter but it should be pointed that races and tournaments could have also increased social opportunities of the first camp.

It can be concluded that social outcomes of a robotic camp could be managed by offering social environments. Number of instructors and involvement of instructors have two fold effect on social environments; less social environment with better classroom management or more social but less peaceful and workable environments.

In group and between groups interaction should be encouraged at robotics camps. In group interaction can be achieved with cooperative learning strategies such as positive interdependence, promotive interaction etc. (further information see literature review chapter). Between groups interaction can be achieved with information and Lego pieces sharing like in the second camp during the work hours. Moreover, eating meals together, playing some physical games outside at free times can also contribute between groups interaction. Although it will be presented at competition section, some tournaments and races will also increase in group and between groups interaction.

\subsubsection{Evaluation of camps' components}

Evaluation in instructional design has two purposes and one of the aspects of "evaluation is determining how well the instruction works: is the instruction effective, efficient, and appealing? And if it is not working well, what changes need to be made?" (Smith \& Ragan, 2005, p. 104). That is, evaluation of the instruction. The answer of the question how should the instruction be structured at a robotic camp will be incomplete without evaluation. Therefore, the children and instructors evaluated the parts of the camps which are activity sheets for the first camp and programming instruction, learning stations and project section for the second camp.

One of the main differences between the two camps' curriculums was that at the first camp activity sheets were prepared and these activities were conducted within programming instruction section. However, programming instruction and mathematics and science activities were separated at the second camp. Programming instruction was given during the first three days of the camp and science and mathematics activities were conducted at learning stations. Last three days of both 
camps were reserved for projects work. The children were asked to evaluate activity sheets at the first camp. On the other hand, the children evaluated parts of the second camp because of the change in the curriculum and revision on the interview schedule. The instructors compared both camps on their instructional design.

Result of the children and instructors' evaluation have shown that, separating STEM activities with learning stations from programming instruction is better instructional approach for a robotics camp. Moreover, with the learning station approach, the limited resources could be used for more productively. For example, if all groups will work on the same activity, all groups will need same resources at the same time. Any extra material for an activity should be provided for all groups. Also, with the learning station approach, the groups could share their unused Lego pieces; because each group creates different robots and each group's demands are different.

The results of the study have shown that projects section of a camp is the most enjoyable and most liked part of a robotics camp. Project is so important that it emphasized at the definition of constructionism. "Constructionism adds the idea that people construct new knowledge with particular effectiveness when they are engaged in building projects that are personally meaningful. Students construct their own knowledge effectively while building creations that interest and excite them, and encourage them to learn" (Mindell et al., 2000, p11). Because the projects section was the most liked part of the camp by the children, the STEM concepts also could be given in half or one day long projects. For example, each learning station could not be labeled as circumference station or gear station; the stations will be introduced with their problems like, "in this station, it is expected that you will create a robot, it will measure the length of the three different black lines". Only the radiuses of the tires are given to the children. Therefore, the children could design a robot with light sensor when the light sensor enter the black are it start to measure the rotation of the motors and measurement will end when the robot reached the end of the black area. Therefore, they could calculate the length of the black area by multiplying the value from rotation sensors and circumference of the tire. They also remember and use how they calculated the circumference of a circle. 
Like the example activity, the activities should not be based on direct instruction and give students chance to use previous knowledge to solve a problem. All learning station activities should be designed in similar way.

\subsubsection{Career}

Technology related summer camps were used to increase children's interest toward technology, computing, and engineering (Miller, Shearer, \& Moskal, 2005). Some of these camps were especially for girls to increase their curiosity and interest toward STEM and also increase the possibilities of the engineering careers (Burket et al., 2008); while the design phase of the camps, career effect of a robotics camp was not foreseen and also the researcher did not investigate that career effect deeply. The career effect emerged when the researcher was investigating children's benefits from the camps. Therefore, the career effect could be more than $10 \%$ for the first camp and $18.2 \%$ for the second camp. Even with these percentages, it could be concluded that robotics a camp has effects on the children's career plan, especially for girls.

Nourbakhsh et al. (2005) also defined a theme "self-identification with science and technology" in their study aimed to evaluate the educational efficacy of robotics. They defined the theme as "developing an interest in technology, confidence in one's ability to work with technology, and interest in pursuing education and future careers in science and technology" (p. 120). Without considering career effects, two robotics camps were designed and without any career emphasis or career related activities, the result of the study shown that a robotics camp has affected career choices of children especially girls'. During the camps, children work on robots that are directly related to electronics and mechanics. Therefore, while they are dealing with these concepts in a joyful way, their fears about engineering and technology could be broken.

Both result of the study and the related literature have shown that a robotics camp has effect on attended children's career choices. Therefore, career options could also be added objectives of a robotics camps like studies in literature (Burket, Small, Rossetti, Hill, \& Gattis, 2008; Miller, Shearer, \& Moskal, 2005; Nourbakhsh et al., 2005). 
Technology, computing and engineering career could be emphasized in an educational robotics camp. For this purpose, some guest speakers who has a career on robotics or engineering could attend the camp to discuss on their areas of expertise, lifestyle and career on robotics (Nourbakhsh et al., 2005). Female speaker is advised, because she could also be a role model for the girls.

\subsection{Discussions on Group Issues}

The second sub-question of the study is what group and gender issues are. As presented in the findings of the study chapter, the sub-question was investigated under three categories a) group size where the optimum group size was investigated, b) group mates' gender where the gender issues were investigated and c) group problems where the group problems, their causes and possible solutions were investigated.

\subsubsection{Group size}

When all instructional setting and goals are decided at design phase of the camps, the instructors should decide on optimal group size. If students lack collaborative skills, the group should be two or three students, later the group size can reach to six (Johnson, Johnson, \& Smith, 1991; Johnson, Johnson, \& Hulubec, 1986). However, the instructors should consider number of the factors when deciding the group size. When the group increases, the abilities, expertise, skills and the number of the minds for getting and processing information will increase. However, the available materials for the task will be another factor when deciding on group size (Johnson et al., 1986; Wilkinson, 2002). The results of the study have also proved that, the main reason for more crowded group is that when the number of the children increase in the group, the number of the ideas and minds will increase, therefore the more discussions will be and they will get more benefit from the group work. However, the designer should balance between the number of the children in a group and available materials. Because, if groups are more crowded than its' optimum size, some of the children in the group will get bored and be occupied in doing unrelated things. 
A criterion for the optimum group size is every child in the group should have duties at any time (Edmiston, n.d.). That could be achieved adjusting group size according to difficulties of activities or vice versa. That is, the activities for a five members group should be more demanding than the activities for a three members group. If one of both variables (number of members in a group and difficulty level of activities) is already defined; the other one should be arranged accordingly.

However, it is hard to balance the difficulty level of activities and group size without robotics camp experience. The activities are explained in diary of the camps sections in detail. Moreover, the results of the study have shown that the group size should be three for a robotics camp and four-members-groups are also acceptable. Therefore, it is advised to inexperienced camp designers to evaluate difficulties of activities in this study and for optimum group size is emerged as there for these activities. If their activities are similar to the activities in this study, three members groups are advised. Also Mauch's (2001) study (with similar activities) and Panadero, Román, and Kloos (2010) study resulted that the group size should be three. If the group size has already been decided and larger than three, the activities should be more demanding to cover every members in the group.

\subsubsection{Group mates' gender}

Gender studies in this subject rooted to Logo. Hughes, Brackenridge, Bibby \& Greenhough (1989) found that mixed (boys, girls) groups performed better on a Logo task than all-boy, and the same as all-girl (cited in Howe, 1997). Yelland (1995) also worked on gender issues on collaborative Logo task. He found that there were no differences in performance measures between girls and boys but there were differences in interaction. Girls showed more verbal interaction in offering information, asking information, offering a proposal and asking for a proposal. Lund and Pagliarini (2000) also reported that girls were at least as enthusiastic as the boys at robotics. Moreover, Nourbakhsh et al., (2004) also stated that girls more likely struggle with programming and they entered the course with less confidence about technology than boys. However, their confidence increased throughout the course significantly more quickly than the boys. As a result, although there are some differences between boys and girls at some variables, there is not any performance 
and enthusiasm difference between boys and girls. As stated before, aim of the researcher is not reveal the difference between the girls and boys on any variables; the aim is define how the groups should be constructed in a robotics camp. However, either robotics or collaborative learning related literature can give clear answer to that question. Findings about group composition on collaborative learning are mixed regarding to heterogeneous or homogeneous forming (Shimazoe \& Aldrich, 2010). Because of the multiple interactions, the group heterogeneity effect is different for different tasks (Dillenbourg, 1999). The result of the study have shown that, most of the children prefer either mixed gender group or group mates' gender does not matter for them. As related literature pointed, there is not any performance and enthusiasm difference between boys and girls, therefore, mixed gender groups are suggested for a robotic camp. Moreover, in mixed gender group, the children could also gain more social skills.

\subsubsection{Group problems}

Group problems at a robotics camp is a bit different than the group problems at a classroom settings, for example hitchhikers or hitch-hiking which means getting same grade all of the group members in spite of a not working one (Johnson et al., 2007; Oakley, Felder, \& Brent, 2004; Shimazoe \& Aldrich, 2010) is a problem for group works at classroom settings. But, results of the study have shown that hitchhiking is not a group problem for a robotics camp because there is not any grading. On the contrary, the group members who "want to make more tasks" are one of the group problems.

"Not interested" group members, group member who "wants to make more" tasks and "no sight of respect" from the group members were emerged main causes of the group problems. In addition, at the second camp the children from the government's special dormitories for the children of divorced parents were main causes of the group problems.

Cohn, (1999) stated that assigning roles to group members is a technic to encourage students to work cooperatively and a clear division of labor is an effective way to prevent hitchhikers. Although, hitchhikers are not a problem at a robotic camp, 
encouraging task sharing or division of the labor could prevent the behavior of the group member who wants to make more tasks on the robots. Moreover, the best solution could be assigning an instructor to each group. Therefore, the instructor could manage the division of the labor, get interest of the group member toward activities and help to solve any conflict in the group.

However, being an instructor in the group could decrease the children's benefit from the group work. The children could not develop their collaborative group skills in a group with an instructor. The children should have chance to solve their problems by themselves. Therefore, support of the instructor should decrease in time that is scaffolding approach should be used in instructors' support. Felder, Brent, and North (1994) also suggested that if any group problems occurred, the instructor should facilitate the discussion for the solution and may suggest alternatives but should not impose solutions on the group. Moreover, Shimazoe and Aldrich (2010) suggest rearranging groups' memberships when problem arise. Although, rearranging groups is a solution, Felder et al. (1994) suggest not to reconstitute groups too often, because, main goal of the cooperative learning is to help the children develop collaborative skills such as leadership, decision making, communication etc. These goals can only be achieved when the children have enough time within the group.

Some children's behaviors from the dormitory disturbed the other group members. Also as an instructor, we had hard times to control these children. We had not received education and experience for dealing these children. If children with similar characteristics will attend a camp, at least one experienced instructor should attend to the camp.

\subsection{Discussions on Competition}

The third sub-question of the study was related with the issues and strategies about cooperation and competition among learners. To answer this question, competition between the groups were encouraged at the first camp; on the contrary, competition was kept at minimum level at the second camp. When competition between the groups was encouraged some negative consequences have been experienced. However, when competition was kept at minimum level, self-competition has 
emerged. Although instructors' data revealed negative consequences of competition, children's' data from both camps resulted with necessity of competition.

Although competitive environments have some drawbacks, in competitive environments the children force their limits (Martin, 1992). Petre and Price (2004) found that robotics competitions motivated students to persist through the competition in spite of frustration or setbacks. As a result of the study, the children should be in competitive environments to work more productive and to enjoy the activities. Because, when a race or tournament arranged, the children work with much more enthusiasm. Panadero, Román, and Kloos (2010) also concluded that competition and social interactions are key issues that contribute to increase the student's motivation in their study with Lego Mindstorms NXTs.

Because the children worked in groups, a group's success was dependent on the each member's effort on the group; therefore the children should work cooperatively in their group to be successful at the races or tournaments. Because there is not any grading, arranging races or tournaments is one way to create positive interdependence (Johnson \& Johnson, 1996; Johnson et al., 1986) in a robotic camp.

Although there is the possibility of negative consequences; the competition should be a part of a robotic camp because competition is a great motivator for the children and source of fun. The instructors should take some precautions to prevent negative consequences of competition. For example, results of a race should not be exaggerated by children; instructors should clearly define that purpose of races are for fun or motivation. The instructors should not let the children be upset when they are defeated in a competition.

\subsection{Discussions on Coaching Issues}

Duties of a coach were clearly defined in the cooperative learning literature. A coach should motivate learners, analyze their performances, provide feedback and advice on the performances and how to learn about how to perform, and provoke reflection on and articulation of what was learned (Jonassen, 1999). Tinzmann et al. (1990) defined duties of a coach as providing hints or cues, giving feedback, redirecting students' efforts, and helping them use a strategy. The main principle of coaching is 
when the students need, providing the right amount of help, not too much or too little, therefore students retain as much responsibility as possible for their own learning.

Although coaching term is used often in the robotics studies, especially that related to robotic competitions such as FLL, effective coaching strategies have not been defined for a robotics camp in the literature. However, FLL defined roles of a coach for the competition in their coaching manual (n.d.). A coach should facilitate instead of giving correct answer. For example, instead of telling "use smaller wheels from the kit" a coach should encourage to brainstorm ideas to make the robot slower or to experiment to find correct wheels. Another useful coaching method is to answer a question with a carefully considered question that forces them to use their knowledge of science and hypothesize logical outcomes. They also pointed out that, a coach should assist young people by facilitating problem-solving and helping them to reach their own solutions.

During the camps the instructors avoided direct instruction, especially when the children work on learning stations and projects; they encourage the children to find solutions to their design or programming problems. As a result of coaching approach, the children stated that they have learned better and they enjoyed their learning. Therefore the instructors for a robotic camp should understand that their duty is being a coach. They should not give direct solution of the problems. They should evaluate the children's performance and give right amount of support to them. Jim, (2010) pointed that frustration and stress built up very quickly when the robots failed to perform what is expected. The instructors should keep them active with right amount of support, should not let them to enter anxiety or boredom area, should keep them in flow state (Csikszentmihalyi, 1991).

\subsection{Discussions on Technical Issues}

The term "technical issues" has a broad meaning in the literature. It includes from electronic parts such as processor of the NXT brick or structure of a sensor (McWhorter, 2005; Mindell et al., n.d.) to combining pieces such as gears (Barak \& Zadok, 2007). The purpose of the study was not to deal with technical parts of a 
robot and reveal electronically and mechanically design problems and propose solution to those problems. Aim of the study is revealing technical problems that children confronted during the activities with Lego Mindstorms NXT sets and computers. Therefore, technical issues should be understood as any technical problems resulted from tools used at the camps.

The most common technical problem was deficiency of the Lego pieces. Especially at the second camp, fifty percent of the children stated deficiency of the pieces. In addition to the basic Lego Mindstorms NXT education set, one resource pack was distributed to each group in both camps. In spite of extra resource pack, deficiency of Lego pieces is still main technical problem of a robotics camp. It is obvious that basic Lego Mindstorms NXT education set do not have enough pieces especially when the children build their own design. Therefore, resource pack is as essential as Lego Mindstorms NXT set. If the children still complain for deficiency of pieces even when resource pack is distributed, they could be encouraged to share pieces with the other groups.

Battery shortage is emerged as another technical problem of a robotics camp. The batteries could not stand all day long activities. Although, they could charge their robots at breaks and nights, sometimes children have to wait charging to continue the activities. Therefore, having extra battery packs are advised and these batteries should always be fully charged. Thus, in the case of battery shortage, these packs should be changed with empty one. Empty batteries should be charged immediately while the camp is continuing.

Also memory shortage of NXT bricks is another technical problem. During a camp, children have to clear memory of the robots, delete old programs to make place to run new programs. While designing a robot camp, the instructors could not do anything for the memory shortage of the robots. However, during the camp, the children should be encouraged to save all their programs on the computer before closing the NXT-G programming environment. Therefore, they can reload their programs, whenever they want. 
Moreover, in any case of technical failure, there should be at least one person who had enough technical competencies to solve technical problems. In addition, an extra robot set and computer also advised as a spare part. Sometimes, technical problems could not be solved instantly; changing parts could be the only solution.

\subsection{Discussions on Challenges}

Brandt, (1998) stated people learn better under some conditions, one of these conditions is what they learn is challenging and when they accept the challenge. Challenges were used in many of the robotics studies (Cocek, 2008; Gandy, Bradley, Arnold-Brookes, \& Allen, n.d.; Krugman, 1998; Panadero et al., 2010; Zubrowski, 2002). Educational robotics camps should have challenging components, because the challenges will increase motivation and engagement (Nourbakhsh et al., 2004).

Nourbakhsh et al. (2004) reported that in their study with robotics, the children were mostly struggled with programming and mechanics. Moreover, Järvinen (1998) expressed that programming appeared to be the most difficult and frustrating task. Similarly, the results of the study have shown that, the children mostly struggled at programming and mechanics. Because the nature of the programming it requires writing the program most of the time it could not work perfectly first time and the rest of the progress is debugging and debugging. Although, simple programming architecture of NXT-G environments, nearly all of the children have not written a programming before, therefore they could be struggled with algorithm of the programming. Therefore, some algorithm activities could be added to a camp curriculum such as programming role play and drawing simple algorithm on a paper. The instructors should also be aware that children struggle mostly in programming and combining Lego pieces. Therefore, the instructors should be more watchful when the children working on programming or combining pieces to better guidance. Because these two concepts are the most challenging parts of a robotics camps, the children could easily frustrate when they are working on them.

\subsection{Discussions on Camp Duration}

The duration of a robotic camp and length of sessions are varied in the literature. Some of the robotics camp were one day long (Burket et al., 2008; Cannon et al., 
2006) some of them were one week long (Murphy \& Rosenblatt, 2000), some of them were two weeks long (Williams et al., 2008) and some of them held at weekends throughout the year (Krugman, 1998). Therefore, the designer can decide the duration of camp according to instructional objectives of the camp. One of the interesting results of the study is that there was not any complain or suggestion about the camp duration at the first camp, however most of the children at the second camp complained about camp duration or length of the breaks. In addition to the children, instructors' data resulted with that the camp should be half day long.

Although camps' durations were the same, the main reason of complaint about camp or breaks' duration was the weather condition. The first camp was conducted in winter season and the second camp was in summer season. The hot summer condition negatively affected the instruction at the second camp.

When designing a robotic camp curriculum, the weather conditions should also be considered; because it affects the children and instructors' performance. If it is possible; there should be an air conditioner in the camp area. Moreover, while designing a robotic camp curriculum, the balance between the contents and the camp duration should be ensured. If a camp is arranged as half day long, they either must sacrifice from the content or the camp must be longer.

\subsection{Camp Design Guidelines}

Guiding research question of the study is what the design principles for an educational robotics training camp are. Robotics camp design related concepts and related suggestions were presented so far. Moreover, an educational robotics camp design guideline is presented in this section. The guideline highlights main issues of educational robotics camp design. Also, sample robotics camp curriculum is presented in the Appendix M.

Design guidelines consist of two parts "design phase" which highlights what should be done during the design phase of a camp and "implementation part" which highlights the main issues during a camp. 


\subsubsection{Design phase}

- Define the target population, grade level of participation should be clearly defined and all participants should be at same level.

- Mathematics and science activities should be prepared according to grade levels of the children.

- Mathematics and science activities should not be prepared based on direct instruction approach. Children should face a complex problem and they should use their mathematics and science knowledge to solve that problem.

- Detailed camp curriculum should be prepared. Each day of the camp should be planned with details. The curriculum should contain programing sections, mathematics and science activities, projects section, and motivational completions.

- Carrier options could be included on the curriculum. A guest speaker could be invited to the camp, or half day of the camps could be reserved for a trip to observe robots' usage in industry or robot related studies etc.

- The camp curriculum should include as much as possible projects, because the children like mostly doing projects with robots.

- For each group one robot sets, one resource pack (extra Lego pieces pack) and one computer should be prepared. Extra robot set and battery packs are advised.

- There should be at least one person who is competent in technical aspects in the team.

- At least one science instructor should be in the team to manage science related activities and discussions. 


\subsubsection{Implementation phase}

- The first session should include introduction that is the participants should introduce themselves (an icebreaker activity could be used for introduction) and be informed about camp rules.

- General robotics information should be given with interesting activities such as role playing, drawing pictures.

- Groups should be created with three or four members with mixed gender.

- Children should have chance to investigate robotics sets to discover parts of the sets.

- During the camp, children should be encouraged to design their own robots.

- Instruction should be organized simple to complex. Especially, mechanics and programming concepts should start from simple.

- Task sharing and division of the labor should be encouraged during group works.

- Competitions are just for motivation; therefore coaches should not let the children break down after a completion.

- Instructors should always remember that their duty is being a good coach. That is they should observe the children's progress and give them right amount of help at proper time.

- Programming and mechanics are the most struggled parts of a camp; therefore the instructors should watch the children progress especially at these activities. The instructors should prevent frustration.

- In-group and between-groups interaction should be encouraged during the camp.

- Social and physical activities should be encouraged at breaks. 
- Sessions could not be so long that children get bored and breaks should be long enough to children let off steam.

\subsection{Implications of the Findings}

In the literature there are some example curriculums for a robotic training camp like Murphy and Rosenblatt (2000) and Nourbakhsh et al., (2005). They shared their robotic camp curriculum and their activities. Aim of this study was to prepare a guideline for a robotic training camp with all aspects. In addition to the robotic camps curriculum in the literature, the success factors were defined and according to children and instructors opinions suggestions were given for each factor. Moreover, based on these suggestions, a sample robotic training camp was presented. Therefore, instructors or institution who wants to prepare a robotic training camp could be benefitted from the results of this study.

Also the instructor who wants to use Lego Mindstorms NXT robotic set in their courses or robotic club can benefit from the results of the study. In addition to the suggestions, recommended activities in the sample camp curriculum (Appendix M) could be helpful to those instructors.

\subsection{Recommendations for Future Research}

Designing a robotic training camp's curriculum is not a single step progress and there is no single best curriculum. Designing a curriculum is a continuous progress and this study is the first step of creating a robotic training camp's curriculum. Therefore, the results of this study should be applied in a robotic camp and the results should be evaluated. Redesign, implementation, and evaluation cycle should be followed to reach better robotic training camp's curriculum.

As a result of the study, the children stated that the camp had effect on their science and mathematics knowledge. As a further study, with a more quantitative approach the robotic training camp's effects on science and mathematics knowledge could be investigated.

To investigate potentials of using robots in formal STEM education, a robotic camp can be organized with STEM teachers. Six teachers from different STEM areas 
(Science and technology, mathematics and technology and design courses) could attend first week of the camp and teachers get training on robotics and programming. Then, the teachers prepare activities with robots aimed to teach a subject in their field. Second week of the camp, children attend to camp and they work with teachers in group work. After they have learnt robotics and programming they work on the activities that teachers had prepared. At the end of the camp, children and teachers' opinions could be taken about implementation of the robots in the formal education.

\subsection{Limitation of the Study}

This study has some limitation. First of all this study was conducted with limited number of the children. Although, it is not the aim of this study to reach a generalization as a qualitative study, conducting similar camp might shed light on to reach better robotic instructional camp's curriculum. Moreover, the assertions could be applied only to similar cases.

While accepting the children to the camp; neither any sampling procedure nor the GPAs of the children were considered. Moreover, the camps were two weeks long and the children were highly motivated toward learning robotics. Therefore, science and mathematics results should be evaluated carefully.

\subsection{The End}

Finally I reached the end. It was a long and hard journey, sometimes enjoyable especially at the camp times, while working with children. I guess I achieved what I wanted to do. I prepared a guideline to whom interested in robotic camps.

Beside this dissertation, I think we achieved very important thing, we present something to those children, which they normally would not meet. They lived two weeks, they could remember whole life. I will.

This journey also affected my thought about media in learning. Before starting to this study, I placed myself near to method in media-method debate. Now, I believe that some media has promising features in learning but without exaggeration. 
I think, I will continue to work on robotics and their instructional features in learning. 


\section{REFERENCES}

2010 - 2011 Coaches Manual. (n.d.). Retrieved March 22, 2012, from http://www.usfirst.org/sites/default/files/2010-2011_Coaches_Manual_Rev 3.pdf

About TEGV. (n.d.). Retrieved August 12, 2011, from http://www.tegv.org

Ackermann, E. (2001). Piaget's constructivism, Papert's constructionism: What's the difference. Future of learning group publication, 5(3), 438.

Argote, L., \& Goodman, P. S. (1986). Investigating the implementation of robotics. In D. Davis (Ed.), Managing technological innovation: Organizational strategies for implementing advanced manufacturing technologies. San Francisco: Jossey-Bass.

BEST. (n.d.). Retrieved August 15, 2011, from http://www.bestinc.org

Baloian, N., Hoeksema, K., Hoppe, U., \& Milrad, M. (2006). Technologies and Educational Activities for Supporting and Implementing Challenge-Based Learning. In D. Kumar \& J. Turner (Eds.), Education for the 21 st Century Impact of ICT and Digital Resources (Vol. 210, pp. 7-16). Boston: Springer.

Barak, M., \& Zadok, Y. (2007). Robotics projects and learning concepts in science, technology and problem solving. International Journal of Technology and Design Education, 19(3), 289-307.

Barker, B. S., \& Ansorge, J. (2007). Robotics as means to increase achievement scores in an informal learning environment. Journal of Research on Technology in Education, 39(3), 229.

Bazeley, P. (2007). Qualitative data analysis with NVivo. London: Sage.

Beer, R. D., Chiel, H. J., \& Drushel, R. F. (1999). Using autonomous robotics to teach science and engineering. Communications of the ACM, 42(6), 85-92.

Bjoerner, T. (2009, June). If I had a Robot it should do Everything for me: Children's Attitudes to Robots in Everyday Life. International Journal of Learning, 16(3), 243-254. 
Bogdan, R. C., \& Biklen, S. K. (2007). Qualitative research for education: An Introduction to theory and methods. Boston: Allen and Bacon.

Brandt, R. (1998). Powerful learning. Alexandria: Association for Supervision \& Curriculum Development.

Bruner, J. S. (1961). The act of discovery. Harvard Educational Review, (31), 21-32.

Burket, S., Small, C., Rossetti, C., Hill, B., \& Gattis, C. (2008). A day camp for middle school girls to create a STEM pipeline. Proceedings of the 2008 American Society for Engineering Education Annual Conference \& Exposition. Pittsburgh, PA.

Burton, R. R., Brown, J. S., \& Fischer, G. (1984). Skiing as a model of instruction. Everyday cognition: Its development in social context, 139-150.

Cannon, K. R., Panciera, K. A., \& Papanikolopoulos, N. P. (2007). Second annual robotics summer camp for underrepresented students. Proceedings of the 12th annual SIGCSE conference on Innovation and technology in computer science education (pp. 14-18).

Cannon, K., LaPoint, M. A., Bird, N., Panciera, K., Veeraraghavan, H., Papanikolopoulos, N., \& Gini, M. (2006). No fear: University of Minnesota Robotics Day Camp introduces local youth to hands-on technologies. Robotics and Automation, 2006. ICRA 2006. Proceedings 2006 IEEE International Conference on (pp. 363-368).

Chambers, J. M., Carbonaro, M., \& Rex, M. (2007). Scaffolding knowledge construction through robotic technology: A middle school case study. Electronic Journal for the Integration of Technology in Education, 6, 55-70.

Cocek, C. C. (2008). Lego Mindstorms and Critical Thinking Skills in the Elementary Classroom. Education. Mount Saint Vincent University.

Cohn, C. L. (1999). Cooperative Learning in a Macroeconomics Course. College Teaching, 47(2), 51.

Creswell, J. (2007). Qualitative inquiry \& research design: Choosing among five approaches. Thousand Oaks: Sage.

Csikszentmihalyi, M. (1991). Flow: The psychology of optimal experience. New York: HarperPerennial.

DeMarrais, K. (2004). Qualitative interview studies: Learning through experience. Foundations for research: Methods of inquiry in, 51-68.

Denis, B., \& Hubert, S. (2001). Collaborative learning in an educational robotics environment. Computers in human behavior, 17(5-6), 465-480. 
Dennen, V. (2004). Cognitive apprenticeship in educational practice: Research on scaffolding, modeling, mentoring, and coaching as instructional strategies. Handbook of research on educational communications, 813-828.

Denzin, N., \& Lincoln, Y. (2005). The Sage handbook of qualitative research. Thousand Oaks: Sage Publications.

Dillenbourg, P. (1999). What do you mean by collaborative learning. Collaborative learning: Cognitive and computational Approaches, 1, 1-19.

Druin, A., \& Hendler, J. A. (2000). Robots for kids: exploring new technologies for learning. San Francisco: Morgan Kaufmann.

Ediger, M. (2011). Learning Stations in the Social Studies. Education, 131(3), 467470.

Edmiston, G. (n.d.). Designing Inclusive Curriculum: Engaging Girls with Science, Engineering and Technology using Robotics. Retrieved February 14, 2012, from http://acce.edu.au/sites/acce.edu.au/files/archived_papers/conf_P_68_designingi nclusivecurriculumfinal.doc

Ersoy, Y. (2006). Innovations in Mathematics Curricula of Elementary Schools-I: Objective, Content and Acquisition. Elementary Education Online, 5(1), 30-44.

First Lego League. (n.d.). Retrieved August 12, 2011, from http://www.usfirst.org/firstlegoleague/community/fll/welcome.html

Fagin, B., \& Merkle, L. (2003). Measuring the effectiveness of robots in teaching computer science. ACM SIGCSE Bulletin (Vol. 35, pp. 307-311).

Felder, R. M., \& Brent, R. (1994). Cooperative Learning in Technical Courses: Procedures, Pitfalls, and Payoffs.

Ferrari, M., \& Astolfo, D. (2007). Building robots with LEGO Mindstorms NXT. Rockland, Mass.: Syngress Media Inc.

Fraenkel, J. R., \& Wallen, N. E. (1993). How to design and evaluate research in education (5th ed.). Boston: McGraw-Hill Higher Education.

Gandy, E. A., Bradley, S., Arnold-Brookes, D., \& Allen, N. R. (n.d.). The use of LEGO Mindstorms NXT Robots in the Teaching of Introductory Java Programming to Undergraduate Students. Retrieved July 15, 2011, from http://www.ics.heacademy.ac.uk/italics/vol9iss1/pdf/paper01.pdf

Griffith Jr, D. S. (2005). FIRST Robotics as a model for experiential problem-based learning: A comparison of student attitudes and interests in science, mathematics, engineering, and technology. ProQuest Dissertations and Theses. Clemson University, United States -- South Carolina. 
Guba, E. (1981). Criteria for assessing the trustworthiness of naturalistic inquiries. Educational Technology Research and Development, 29(2), 75-91.

Hammer, D. (1997). Discovery Learning and Discovery Teaching. Cognition and Instruction, 15(4), 485-529.

Harel, Idit. (1991). Children designers. Ablex Pub. Corp. (pp. 24-27). New Jersey: Ablex Publishing.

Howe, C. (1997). Gender and classroom interaction. Edinburgh: SCRE Publication.

Hussain, S., Lindh, J., \& Shukur, G. (2006). The effect of LEGO Training on Pupils ' School Performance in Mathematics, Problem Solving Ability and Attitude : Swedish Data. Educational Technology \& Society, 9(3), 182 - 194.

Jim, C. K. W. (2010). Teaching with LEGO mindstorms robots: Effects on learning environment and attitudes toward science. ProQuest Dissertations and Theses. The University of Texas at Dallas, United States -- Texas.

Johnson, D. W., \& Johnson, R. T. (1996). Cooperation and the use of technology. In D. Jonassen (Ed.), Handbook of research for educational communications and technology (Vol. 1, pp. 1017-1044). New York: Macmillan.

Johnson, D. W., \& Johnson, R. T. (2008). Social interdependence theory and cooperative learning: The teacher's role. In R. M. Gillies, A. Ashman, \& J. Terwel (Eds.), Theteacher's role in implementing cooperative learning in the classroom (pp. 9-37). New York: Springer.

Johnson, D. W., Johnson, R. T., \& Smith, K. A. (1991). Active learning: Cooperation in the college classroom. Minnesota: Interaction Book Co.

Johnson, D. W, \& Johnson, R. T. (1984). Cooperative Small-Group Learning. Curriculum Report. 14, 12-18.

Johnson, D. W, \& Others, A. (1984). Circles of learning: Cooperation in the classroom. New Jersey: Englewood Cliffs. Alexandria, VA: Association for Supervision and Curriculum Development.

Johnson, D. W., Johnson, R. T., \& Smith, K. (2007). The State of Cooperative Learning in Postsecondary and Professional Settings. Educational Psychology Review, 19(1), 15-29.

Johnson, J. (2003). Children, robotics, and education. Artificial Life and Robotics, $7(1), 16-21$.

Jonassen, D. (1999). Designing constructivist learning environments. In C. M.

Reigeluth (Ed.), Instructional-design theories and models (Vol. 2, pp. 215-239).

New Jersey: Lawrence Erlbaum. 
Järvinen, E. M. (1998). The Lego/Logo learning environment in technology education: An experiment in a Finnish context. Journal of Technology Education, 9(2), 47-59.

Kafai, Y. B., \& Resnick, M. (1996). Constructionism in practice: Designing, thinking, and learning in a digital world. New Jersey: Lawrence Erlbaum.

Kalaycığlu, S. Çelik, K. Çelen, Ü. Türkyılmaz, S. (2010). Temsili Bir Örneklemde Sosyo-Ekonomik Statü (SES) Ölçüm Aracı Geliştirilmesi: Ankara Kent Merkezi Örneği. Journal of Sociological Research, 13(I).

Keathly, D., \& Akl, R. (2007). Attracting and Retaining Women in Computer Science and Engineering: Evaluating the Results. 2007 ASEE Annual Conference.

Kee, D. (n.d.). Retrieved May 12, 2010, from http://www.damienkee.com/home/2011/8/20/domabot-classroom-robotdesign.html

Kelly, J. F. (2010). Lego Mindstorms NXT-G Programming Guide. New York: Springer.

Kirac, S. (2006). Ömrümden Uzun İdeallerim Var. İstanbul: Anı.

Korchnoy, E., \& Verner, I. M. (2008). Characteristics of learning computercontrolled mechanisms by teachers and students in a common laboratory environment. International Journal of Technology and Design Education, 20(2), 217-237.

Krugman, M. (1998). Using themes for hands on robotics courses: Colorado school of mines robocamps. National Conference on Educational Robotics (pp. 97106).

Kurfiss, J. G. (1988). Critical Thinking: Theory, Research, Practice, and Possibilities. Washington, D.C.: Association for the Study of Higher Education.

Lau, K. W., Tan, H. K., Erwin, B. T., \& Petrovic, P. (1999). Creative Learning in School with LEGO Programmable Robotics Products. Frontiers in Education Conference, 1999. FIE'99. 29th Annual (Vol. 2, pp. 12D4-26). IEEE.

Lego Mindstorms NXT Hardware Developer Kit. (n.d.). Retrieved August 18, 2011, from http://mindstorms.lego.com/en-us/support/files/default.aspx

Lincoln, Y. S., \& Guba, E. G. (1985). Naturalistic inquiry (Vol. 75). London: Sage Publications.

Lindh, J., \& Holgersson, T. (2007). Does lego training stimulate pupils' ability to solve logical problems? Computers \& Education, 49(4), 1097-1111. 
Lund, H. H., \& Pagliarini, L. (2000). RoboCup Jr. with LEGO MINDSTORMS. Robotics and Automation, 2000. Proceedings. ICRA 'O0. IEEE International Conference on (Vol. 1, pp. 813-819 vol.1).

MEB. (2005). PISA 2003 Uluslararası Öğrenci Değerlendirme Projesi, Ulusal Nihai Rapor. Ankara: Eğitim Araştırma ve Geliştirme Dairesi Yayınları.

MEB. (2007). PISA 2006 Uluslararası Öğrenci Değerlendirme Projesi, Ulusal Ön Rapor. Ankara: Eğitim Araştırma ve Geliştirme Dairesi Yayınları.

Martin, F. (1988). Children, cybernetics, and programmable turtles. Unpublished Masters Thesis, Massachusetts Institute of Technology Media Laboratory. Massachusetts Institute of Technology.

Martin, F. G. (1992). Building robots to learn design and engineering. Frontiers in Education Conference (pp. 213-213).

Martin, F., Mikhak, B., Resnick, M., Silverman, B., \& Berg, R. (2000). To mindstorms and beyond: Evolution of a construction kit for magical machines. Robots for kids: Exploring new technologies for learning (pp. 9-33). San Francisco: Morgan Kaufmann.

Mataric, M. J., Koenig, N., \& Feil-Seifer, D. (2007). Materials for enabling hands-on robotics and STEM education. AAAI spring symposium on robots and robot venues: Resources for AI education.

Mauch, E. (2001). Using Technological Innovation To Improve the Problem-Solving Skills of Middle School Students: Educators' Experiences with the LEGO Mindstorms Robotic Invention System. Clearing House, 74(4), 211-214.

Maxwell, J. W. (2006). Re-situating Constructionism. The International Handbook of Virtual Learning Environments, 279-298.

McGoldrick, C., \& Huggard, M. (2004). Peer learning with Lego Mindstorms. Frontiers in Education, 2004. FIE 2004. 34th Annual (pp. S2F-24-9 Vol. 3).

McNally, M., Goldweber, M., Fagin, B., \& Klassner, F. (2006). Do lego mindstorms robots have a future in CS education? Proceedings of the 37th SIGCSE technical symposium on Computer science education - SIGCSE '06, 61. New York, New York, USA: ACM Press.

McNerney, T. (2004). From turtles to Tangible Programming Bricks: explorations in physical language design. Personal and Ubiquitous Computing, 8(5), 326-337.

McWhorter, W. (2005). Turtles and beyond: A history of programmable robots. Unpublished manuscript.

Merriam, S. B. (2009). Qualitative research: A guide to design and implementation. San Francisco: Jossey-Bass. 
Miles, Matthew B., \& Huberman, A. M. (1994). Qualitative data analysis: An expanded sourcebook. (p. 352). London: Sage Publications.

Miles, M.B., \& Huberman, A. M. (1999). Qualitative data analysis. Scenario. London: Sage Publications.

Miller, L., Shearer, S., \& Moskal, B. (2005). Technology Camp 101: Stimulating Middle School Students' Interests in Computing. Proceedings Frontiers in Education 35th Annual Conference, S1F-26-S1F-31. IEEE.

Mindell, D., Beland, C., Wesley, C., Clarke, D., Park, R., \& Trupiano, M. (n.d.). LEGO mindstorms, the structure of an engineering (r)evolution. Retrieved July 15, 2011, from web.mit.edu/6.933/www/Fall2000/LegoMindstorms.pdf

Mindstorms: What is NXT. (n.d.). Retrieved August 12, 2011, from http://mindstorms.lego.com

Mosley, P., \& Kline, R. (2006). Engaging Students: A Framework Using LEGO® Robotics to Teach Problem Solving. Information Technology, Learning, and Performance Journal, 24(1).

Murphy, R. R., \& Rosenblatt, M. (2000). Robocamp: One Hands-on Week of Exploring Science through Robotics. In Allison Druin \& J. Hendler (Eds.), Robots for kids: Exploring new technologies for learning (pp. 297-331). San Francisco: Morgan Kaufmann.

National Institute of Food and Agriculture. (n.d.). What is a 4-H Club ? Retrieved January 16, 2012, from http://www.csrees.usda.gov/nea/family/res/pdfs/What_Club_REVISED_7_11.p df

National Robotics Challenge. (n.d.). Retrieved August 15, 2011, from http://www.nationalroboticschallenge.org

National Science Board. (n.d.). Preparing the next generations of STEM innovators: Identifying and developing our nations human capital. Retrieved August 18, 2012, from http://www.nsf.gov/nsb/stem/innovators.jsp

Nordstrom, G., Reasonover, G., \& Hutchinson, B. (2009). Attracting Students to Engineering Through Robotics Camp. ASEE Southeast Section Conference.

Nourbakhsh, I R, Hamner, E., Crowley, K., \& Wilkinson, K. (2004). Formal measures of learning in a secondary school mobile robotics course. Robotics and Automation, 2004. Proceedings. ICRA '04. 2004 IEEE International Conference on (Vol. 2, pp. 1831-1836 Vol.2).

Nourbakhsh, Illah R., Crowley, K., Bhave, A., Hamner, E., Hsiu, T., PerezBergquist, A., Richards, S., et al. (2005). The Robotic Autonomy Mobile 
Robotics Course: Robot Design, Curriculum Design and Educational Assessment. Autonomous Robots, 18(1), 103-127.

Nugent, G., Barker, B., \& Grandgenett, N. (2010). Impact of Robotics and Geospatial Technology Interventions on Youth STEM Learning and Attitudes. Journal of Research on Technology in Education, 42(4), 391-408.

OECD. (2010). PISA 2009 Results: What Students Know and Can Do: Student Performance in Reading, Mathematics and Science (Volume I) (Vol. I). PISA: OECD Publishing.

Oakley, B., Felder, R., \& Brent, R. (2004). Turning student groups into effective teams. Journal of Student, 2(1), 9-34.

Ohio STEM Learning Network. (n.d.). Ohio STEM Learning Network. Retrieved August 19, 2011, from http://www.osln.org

Ozbay, M., Buyukikiz, K. K., \& Uyar, Y. (2011). İlköğretim yedinci sinif öğrencilerinin yazili anlatimlarindaki kelime hazineleri üzerine bir inceleme. Mustafa Kemal Universitesi Journal of Social Science Institute, 8(15), 149-173.

Ozbay, O. (2003). Merton's Strain Theory: Evidence from the High Schools in Ankara. Cumhuriyet Universitesi Sosyal Bilimler Dergisi, 27(1), 59-76.

Packer, J. (2006). Learning for Fun: The Unique Contribution of Educational Leisure Experiences. Curator: The Museum Journal, 49(3), 329-344.

Panadero, C. F., Román, J. V., \& Kloos, C. D. (2010). Impact of learning experiences using LEGO Mindstorms ${ }^{\circledR}$ in engineering courses. Education Engineering (EDUCON), 2010 IEEE (pp. 503-512).

Papert, S. (1993). Mindstorms: Children, computers, and powerful ideas. New York: Basic Books.

Papert, S. (1999). What is Logo? Who needs it. Logo Philosophy and Implementation (p. iv-Xvi). Logo Computer Systems Inc.

Papert, S., \& Harel, I. (n.d.). Situating constructionism. Retrieved July 15, 2011, from http://www.papert.org/articles/SituatingConstructionism.html

Papert, S., \& Solomon, C. (1971). Twenty things to do with a computer. Retrieved July 15, 2011, from http://dspace.mit.edu/handle/1721.1/5836

Patton, M. (1990). Qualitative evaluation and research methods . London: Sage Publications.

Perdue, D. (2008). The Unofficial LEGO Mindstorms NXT Inventor's Guide. San Francisco: No Starch Press. 
Petre, M., \& Price, B. (2004). Using Robotics to Motivate "Back Door" Learning. Education and Information Technologies, 9(2), 147-158.

Ranganathan, P., Schultz, R., \& Mardani, M. (2008). Use of LEGO NXT

Mindstorms brick in engineering education. 2008 ASEE North Midwest (pp. 112).

Rasmussen, J. (2001). The importance of communication in teaching: A systemstheory approach to the scaffolding metaphor. Journal of Curriculum Studies, $33(5), 569-582$.

Reigeluth, C. M. (1999). The elaboration theory: Guidance for scope and sequence decisions. In C. M. Reigeluth (Ed.), Instructional-Design Theories and Models: A New Paradigm of Instructional Theory. (Volume II). Mahwah, NJ: Lawrence Erlbaum Assoc.

Reiser, R. a. (2001). A history of instructional design and technology: Part II: A history of instructional design. Educational Technology Research and Development, 49(2), 57-67.

Robinson, M. (2005). Robotics-Driven Activities: Can They Improve Middle School Science Learning? Bulletin of Science, Technology \& Society, 25(1), 73-84.

Rogers, C., \& Portsmore, M. (2004). Bringing engineering to elementary school. Journal of STEM Education, 5(3-4), 17-28.

Ruiz-del-Solar, J., \& Aviles, R. (2004). Robotics Courses for Children as a Motivation Tool: The Chilean Experience. IEEE Transactions on Education, 47(4), 474-480.

Saldana, J. (2009). The coding manual for qualitative researchers. London: Sage Publications.

Sargent, R. (1995). The programmable LEGO brick: Ubiquitous computing for kids. Cambridge, MA: Media Laboratory Master's Thesis, Massachusetts Institute of Technology.

Sargent, R., Resnick, M., Martin, F., \& Silverman, B. (1996). Building and learning with programmable bricks. Constructionism in practice: Designing, thinking and learning in a digital world, 161-174.

Scott, C. E. (2009). A comparative case study of the characteristics of science, technology, engineering, and mathematics (STEM) focused high schools. (M. Hjalmarson, Ed.)Development. George Mason University, United States -Virginia.

Shimazoe, J., \& Aldrich, H. (2010). Group Work Can Be Gratifying: Understanding \& Overcoming Resistance to Cooperative Learning. College Teaching, 58(2), 52-57. 
Simsek, H., \& Yildirim, A. (2008). Sosyal Bilimlerde Nitel Araştırma Yöntemleri (p. 366). Ankara: Şeçkin Yayıncılık.

Slavin, R. E. (1991). Student team learning: A practical guide to cooperative learning. Washington, DC: National Education Association.

Smith, P. L., \& Ragan, T. J. (2005). Instructional Design (3rd ed.). New York: John Willey \& Sons.

Strauss, A., \& Corbin, J. (1998). Basics of qualitative research: Techniques and procedures for developing grounded theory. London: Sage Publications.

Study of educational impact of the LEGO Dacta materials-INFOESCUELA-MED. Final Report. (n.d.). Retrieved August 10, 2011, from http://www.robotic.qc.ca/index.php?option=com_docman \&task=doc_download\&gid=18\&Itemi $\mathrm{d}=101$

Sullivan, F. R. (2008). Robotics and science literacy: Thinking skills, science process skills and systems understanding. Journal of Research in Science Teaching, 45(3), 373-394. Wiley Online Library.

Şık, A., \& Koç, A. (2011). Teknoloji ve Tasarım dersi programı üzerine iş eğitimi öğretmenlerinin görüş ve düşüncelerinin belirlenmesi (antalya ili örneği). Gazi Üniversitesi Endüstriyel Sanatlar Ĕ̈itim Fakültesi Dergisi, 58-71.

Talim ve Terbiye Kurulu Başkanlığı (TTKB). (2005). Talim ve Terbiye Kurumu Baskanligi İlkögretim 1-5. Sınıf Programları Tanıtım El Kitabı.

Talim ve Terbiye Kurulu Başkanlığı (TTKB). (2006a). İlköğretim Fen ve Teknoloji Dersi (6,7 ve 8. Sınıflar) Öğretim Programı.

Talim ve Terbiye Kurulu Başkanlığı (TTKB). (2006b). İlköğretim Teknoloji ve Tasarım Dersi Öğretim Programı ve Klavuzu (6, 7 ve 8. Sınıflar ).

Talim ve Terbiye Kurulu Başkanlığı (TTKB). (2009). İlköğretim Matematik Dersi 15. Sınıflar Öğretim Programı.

Tinzmann, M., Jones, B., Fennimore, T., Bakker, J., Fine, C., \& Pierce, J. (1990). What is the collaborative classroom. Proceedings of NCREL.

Tsupros, N., Kohler, R., \& Hallinen, J. (2009). STEM Education : A Project to Identify the Missing Components.

TUIK. (2010). Bölgesel Göstergeler TR51 Ankara. Ankara:Türkiye İstatistik Kurumu.

Tuysuz, C., \& Aydin, H. (2009). İlköğretim Fen ve Teknoloji Dersi Öğretmenlerinin Yeni Fen ve Teknoloji Programına Yönelik Görüşleri. (Turkish). The 
Elementary School Science and Technology Teachers' Perceptions Toward To New Science and Technology Curriculum. (English), 29(1), 37.

Van Maanen, J. (1979). Reclaiming qualitative methods for organizational research: A preface. Administrative Science Quarterly, 24(4), 520-526.

Vollstedt, A.-M. (2005). Using robotics to increase student knowledge and interest in science, technology, engineering, and math. (E. L. Wang, Ed.)ProQuest Dissertations and Theses. University of Nevada, Reno, United States -- Nevada.

Watt, M. (1982). What is Logo? Creative Computing, 8(10), 112-29.

Webb, N. M., \& Palincsar, A. S. (1996). Group processes in the classroom. In D. C. Berliner \& R. C. Calfee (Eds.), Handbook of educational psychology (pp. 841873). New York: Macmillan.

Welch, A. (2007). The effect of the FIRST Robotics Competition on high school students' attitudes toward science. (D. Huffman, Ed.)ProQuest Dissertations and Theses. University of Kansas, United States -- Kansas.

Wilczynski, V., \& Flowers, W. (2006). FIRST robotics competition: University curriculum applications of mobile robots. International Journal of Engineering Education, 22(4), 792-803. International Journal of Engineering Education.

Wilkinson, I. (2002). Small-group composition and peer effects. International Journal of Educational Research, 37(5), 425-447.

Williams, D., Ma, Y., Prejean, L., \& Ford, M. (2008). Acquisition of Physics Content Knowledge and Scientific Inquiry Skills in a Robotics Summer Camp. Journal of Research on Technology in Education, 40(2), 201-216.

Wyeth, P., Venz, M., \& Wyeth, G. (2004). Scaffolding children's robot building and programming activities. RoboCup 2003: Robot Soccer World Cup VII, 308-319. Springer.

Yelland, N. (1995a). Mindstorms or a storm in a teacup? A review of research with Logo. International Journal of Mathematical Education in Science and Technology, 26(6), 853-869.

Yelland, N. (1995b). Collaboration and learning with Logo: does gender make a difference? The first international conference on Computer support for collaborative learning (pp. 397-401). L. Erlbaum Associates Inc.

Yin, R. K. (2009). Case study research: Design and methods (Vol. 5). Thousand Oaks: Sage Publications.

Zubrowski, B. (2002). Integrating science into design technology projects: Using a standard model in the design process. Journal of Technology Education, 13(2), $47-65$. 


\section{APPENDIX A}

\section{INTERVIEW SCHEDULE}

Merhaba,

Ben Memet ÜÇGÜL. Sizlerle daha önce de konuştuğumuz gibi bu yaptığımız robot etkinliği aynı zamanda benim doktora tezimin bir parçası. Simdi sizinle etkinlikte yaşadıklarımızla ilgili biraz konuşmak istiyorum.

Öncelikle belirtmeliyim ki; soracağım sorular kesinlikle sizin bilginizi ölçme amaçlı değildir. Ayrıca, cevaplarınızı benden başka kimse görmeyecektir. Sadece size ait olan demografik bilgileri kullanabilirim. Bu noktada da sizin bilgilerinizi takma ad kullanarak yazabilirim.

Soracağım soruların hiçbirinin doğru yada yanlış cevapları yoktur. Ben sadece sizin bu konu hakkında ne düşündügünüzü merak etmekteyim.

Eğer sizin için de bir sakıncası yoksa görüşmemizi kaydetmek istiyorum. Görüşmemiz yaklaşık 30-40 dakika sürecektir. Görüşmeye başlamadan önce bana sormak istediğiniz bir şey var mı? Görüşmenin herhangi bir noktasında ara vermek isterseniz bana söylemeniz yeterli.

Görüşmeye başlayabilir miyiz?

3. Robotlarla ilk karşılaştığın zamanı hatırlıyor musun? Biraz anlatabilir misin?

a. Neler hissettin?

i. Hislerin nedenleri?

4. Robotlar ile çalıștığın süreci değerlendirir misin? 

a. Eğleniyor musun?
b. Neler hissediyorsun?
c. Sana olan faydaları nelerdir?

i. Örneklendirebilir misin?

d. Bu süreçte neler öğrendiğini düşünüyorsun?

i. Örneklerle açıklayabilir misin?

e. Zorlandığınız zamanlar oldu mu?

i. Örneklerle açıklayabilir misin?

5. Grup arkadaşlarınla sorunlar yaşadınız mı? Ne tip sorunlar?

Probe: Sorumluluk almama

Probe: Kişisel sorunlar

a. Bu sorunlar nasıl çözüldü/çözülmeli?

b. Eğitmenin rolü ne olmalı?

6. Biz kampı bu şekilde yaptık ama, sizce kamp nasıl olmalı?/ Olmalıydı?

a. Grup:

i. Gruplardaki öğrenci sayısı ne olmalı? Neden?

ii. K1z ve erkek sayısı nasıl olmalı? Neden?

iii. Bireysel farklılıklar önemli mi? Bireysel farklılıklar nasıl değerlendirilmeli?

Probe: Zeka (uzamsal zeka, matematik zekası v.b.), ilgi, yetenek, bilişsel gelişim düzeyi, yaş, cinsiyet.

b. Eğitim:

i. Bir eğitim verilmeli mi? Neden?

ii. Verilecek ise eğitim nasıl olmalı? (Detaylı açıklama)

Probe: Yaparak, yüzyüze, kitaptan v.b.

iii. Eğitmen size nasıl yardımcı olmalı? (Eğitimde - Etkinlik esnasinda)

c. Etkileşim:

i. Grup içi etkileşim nasıl olmalı?

ii. Gruplar arası etkileşim nasıl olmalı? Rekabet olmalı mı? Neden?

iii. $\mathrm{Bu}$ etkileşimi sağlamak için eğitmene ne gibi görevler düşmektedir? 
d. Teknik

i. Yaşanabilecek teknik problemler neler olabilir?

ii. Bu problemlerin üstesinden nasıl gelinebilir?

e. Etkinlik saatleri

i. Bir günde kaç saat olmalı? Neden?

ii. Teneffüsler? Neden?

7. Kampta en çok hoşunuza giden/olumlu şeyler nelerdi?

8. Kamptaki en sıkıcı/olumsuz şeyler nelerdi?

9. Kampın bölümlerini nasıl değerlendirirsiniz?

a. İlk üç günlük robot ve programlama eğitimi

b. Sonraki üç günlük istasyon çalışmaları

c. Proje çalışması

10. Robotlar/teknoloji konusunda kendini nasıl görüyorsun?

a. Kamp öncesinde

b. Kamp sonrasinda

11. Eklemek istediğiniz başka bir şey var mı?

Teşekkürler :) 


\section{CAMP EVALUATION FORM}

Ad1:

Tarih: / /2010

Soyadi:

Grup:

$\mathrm{Bu}$ gün etkinlikte neler öğrendiniz?

Grup arkadaşlarınızla yaşadığınız olumlu - olumsuz deneyimler nelerdir?

Eğitmen ile ilgili yaşadığınız olumlu - olumsuz deneyimler nelerdir?

Genel olarak bugünkü etkinliği değerlendirir misiniz? (Eksik olan noktalar, önerileriniz, yaşadığınız sizi etkileyen olumlu ya da olumsuz olaylar ) 
APPENDIX C

\section{RESEARCH PERMISSION}

E. T.C.

MiLLî EĞITIM BAKANLIĞI

Eģitimi Araşturma ve Geliştirme Dairesi Başkapnlığ

Sayı : B.08.0.EGD.0.07.00.00.311- $308 / 1846$

Konu : Araşırma Izni

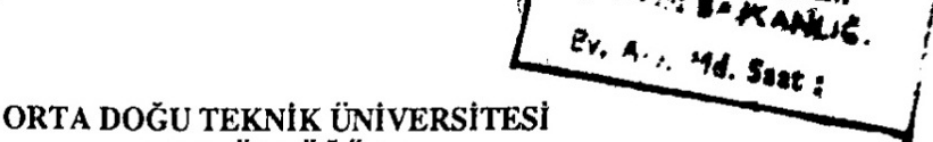

\section{REKTÖRLÜGÜNE}

Ilgi : a) 29/06/2010 tarih ve B.30.2.ODT.72.00.00/400/4041 sayılı yazı

b) 28.02.2007 tarih ve B.08.0.EGD.0.33.05.311-311/1084 sayıl Makam Onayı ile Uygulamaya Konulan "Millı̂ Eğitim Bakanlığına Bağlı Okul ve Kurumlarda Yapılacak Araştırma ve Araştırma Desteğine Yönelik İzin ve Uygulama Yönergesi

Üniversiteniz Bilgisayar ve Öğretim Tcknolojileri Eğitimi EABD Doktora Programı ögrencisi Mehmet Üçgül'ün "Eğitsel Robot Kamplarında Kritik Başarı Faktörleri: Durum Çalışması" başlıklı araştırmasında kullanılacak veri toplama araçlarını Türkiye Eğitim Gönüllüleri Vakfı Etimesgut Eğitim Parkı ve Bingöl-Solhan Yatılı Illkögretim Bölge Okulu'nda uygulama izin talebi incelenmiştir.

Üniversiteniz tarafından kabul edilerek onaylı bir örneği Bakanlığımızda muhafaza edilen ( 3 sayfa - 12 sorudan oluşan) veri toplama araçlanın ve gerekli izin belgelerini, ilgi (a) yazıda belirtilen illerdeki eğitim kurumlarının öğrencilerine gönüilülük esas olmak ve kimlik bilgilerini belirtilmemek kaydıyla uygulanmasında bir sakınca görülmemektedir.

Ilgı (b) Yönergenin 5.Maddesinin (o) bendi uyarınca teslim tutanağının imzalanarak araştırmanın bitiminde sonuç raporunun $i k i$ örneğinin Bakanlığımıza gönderilmesi gerekmektedir.

Bilgilerinizi ve gercginı rica cderim.

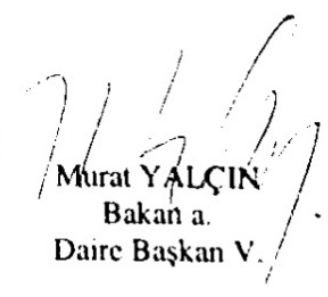

Ek: 1.Görüşme Formu (3 sayfa)

26.07.:0 ก14025 


\title{
APPENDIX D
}

\section{PARENTAL PERMISSION FORM}

\author{
Sayın Veli,
}

TÜBİTAK tarafından desteklenen "Genç Mucitler Robot Geliştiriyor, Bilimi Keşfediyor Kampı” Atılım Üniversitesi, ODTÜ ve Dokuz Eylül Üniversitesi'nde çalışan bilim insanlarının oluşturduğu bir ekip tarafından yürütülmektedir. Türkiye Eğitim Gönüllüleri Vakfı (TEGV) Semahat - Dr.Nusret Arsel Eğitim Parkı'nda 25 Ocak- 5 Şubat 2010, saat 9:30-16:30 arasında gerçekleşecek olan bilim kampımızın etkinliğini ölçmek için kısa anketler, gözlemler ve görüşmeler yapılması planlanmaktadır. Bu kapsamda ekibimiz tarafından görüntü ve ses kaydı yapılması öngörülmektedir. Bu kayıtlar sadece proje ekibi tarafından incelenecektir. Bu çalışmaya katılım gönüllülük esasına dayanmaktadır. Öğrenciler arzu ettiği takdirde, hiçbir yaptırıma maruz kalmaksızın katılımdan vazgeçme hakkına sahiptir.

$\mathrm{Bu}$ bilimsel çalışmanın yanı sıra projenin tanıtımı için kamp esnasında çekilen fotoğraf ve videolar İnternet sitemizde tanıtım amacıyla yayınlamayı düşünülmektedir.

Son olarak, 29 Ocak 2010 tarihinde ODTÜ Bilim ve Teknoloji Müzesi'ne bir gezi etkinliği planlanmaktadır. Ücretsiz olan gezimizde katılımcılarımızın ulaşımı servis aracılığıly sağlanacaktır.

Çalışmamıza ve kampımıza katkılarınızdan dolayı şimdiden teşekkür ederim. Daha fazla bilgi için proje yöneticisiyle iletişim kurabilirsiniz.

\section{Proje Yöneticisi}

Yrd. Doç. Dr. Erol ÖZÇELİK

Atılım Üniversitesi Bilgisayar Mühendisliği Bölümü

Kızılcaşar Mah. 06836 İncek/ANKARA

Telefon:586 8793

E-posta:eozcelik@atilim.edu.tr

Proje Ekibi:

Doç. Dr. Kürşat Çağgltay (ODTÜ, Eğitim Fakültesi), Dr. Bülent Cavaş (Dokuz Eylül Üniversitesi, Eğitim Fakültesi), Uzman Memet Üçgül (ODTÜ, Eğitim Fakültesi), Uzman Nuri Kara (ODTÜ, Eğitim Fakültesi) 
Yukarıda açıklamasını okuduğum çalışmaya, çocuğumun katılımına izin veriyorum.

- İzin vermiyorsanız lütfen kutuya çarpı işareti koyunuz.

Kamp esnasında çocuğumun çekilen fotoğraf ve videoların projenin İnternet sitesinde tanıtım amacıyla yayınlamasına izin veriyorum.

- İzin vermiyorsanız lütfen kutuya çarpı işareti koyunuz.

Çocuğumun ODTÜ Bilim ve Teknoloji Müzesi'ne gitmesine izin veriyorum.

- İzin vermiyorsanız lütfen kutuya çarpı işareti koyunuz.

Velinin Adı Soyadı:

İmzası:

Tarih: 
APPENDIX E

THE FIRST CAMP CURRICULUM

\section{E.1 The First Day}

Etkinlik Tarihi (Gün/Ay/Yıl): 25/01/2010

Etkinliğin Adı: Robotlara ve Lego Mindstorms NXT Ortamına Giriş

Hedef Kitle: İlköğretim 6. sınıflar

Etkinliği yaptıracak kişi(ler):

\section{Takım koçları:}

Etkinliğin Amacı: Bu etkinliğin üç amacı vardır. Birinci amaç, örnek robotlar sunarak öğrencilerin ilgisini çekmek ve öğrencilerin robotlarla neler yapabileceklerini göstererek motivasyonlarını artırmak. İkinci amaç, robot kavramını tartışarak robotların karakteristik özelliklerini tanımlamak. Son olarak da, Lego Mindstorms NXT'ye giriş yaparak öğrencilerin çalışacağı ortamı tanıtmaktır.

Etkinliğin Konusu: Etkinliğin konusu robotların içinde bulundukları ortamı nasıl algılayıp ona göre hareket ettiklerini ve nasıl zeki davrandıklarını öğrencilere göstermektir. Robotların, belirli bir görevi başarmak için tanımlanan algoritma dahilindeki sıralı komutları nasıl yaptıkları tartışılacaktır. Lego Mindstorms NXT çalışma ortamındaki donanımsal ve yazılımsal bileşenler öğrencilere tanıtılacaktır. Basit bir robot yapmanın ne kadar kolay olduğu gösterilerek öğrencilerin motivasyonu ve robot geliştirmeye yönelik öz-yeterlilik inançları artırılacaktır.

\section{Etkinliğin Süresi:}

09:30 - 10:20 Robot kampının tanıtılması, kuralların açıklanması ve ön testlerin uygulanmasi
$10: 20-10: 30$
Ara
$10: 30-11: 20$
“Zeki Robotlar İşbaşında” gösterimi
$11: 20-11: 30$
Ara
$11: 30-12: 20$
"Vol.i" filminin bir kısmının izlenmesi ve tartışma
$12: 20-13: 30$
Öğle yemeği
$13: 30-14: 20$
Robotlar üzerine tartışma 
14:20 - 14:30 Ara

14:30 - 15:20 Lego Mindstorms ortamına giriş

15:20 - 15:30 Ara

15:30 - 16:20 İlk robotumu yapıyorum aktivitesi

\section{Kullanılacak Malzemeler:}

Projeksiyon cihazı

Proje ekibinin önceden yaptığ çalışır durumda olan örnek robotlar

"Vol.i" filmi

Her bir grup için Lego Mindstorms seti, bilgisayar, resim kağıdı ve pastel boya seti

Etkinliğin Nasıl Yapıldığı (Rehber sayısı, katılımcı sayısı, senaryolaştırılmış ayrintılı uygulama planı vs.):

Rehber saylst: 3

Katılımcı sayısı: 24 (6 grup)

Robot kampının tanıtılması ve ön testlerin uygulanması. Önce öğrencilerin birbirleriyle tanışması için bir aktivite yapılır. Daha sonra öğrencilere önce robot kampı hakkında genel bilgiler verilecektir. Kampın kuralları katılımcılara açıklanacaktır. Öğrencilerden beklenenler, aktivitelerin içerikleri anlatılacak ve kampta ne gibi robotlar geliştirecekleri projektör aracılığıyla sunulacaktır. Daha sonra öğrencilerin soru sormaları teşvik edilerek soruları cevaplandırılacaktır. Son olarak ön testler uygulanacaktır.

“Zeki Robotlar İşbaşında” gösterimi. Öğrencilerin Lego Mindstorms teknolojisi ile neler yapabileceklerine örnekler gösterilecektir. Hem proje personeli ve TEGV'deki diğer öğrenciler tarafından geliştirilmiş robotların sınıfta sunumu yapılacak, hem de projektörden öğrencilerin yaşıtlarının geliştirdikleri robotlar sunulacaktır. Buradaki amaç, çalışan robotlar göstererek öğrencilerin motivasyonunu artırmaktır. Gözlem aktivitesinin daha verimli olması için öğrencilere aktiviteden önce cevaplamaları istenen sorular verilecektir. Bu sayede öğrencilerin gözlemdeki rolünün salt izleyen değil soruların cevaplarını araştıran olması sağlanacaktır. Örneğin, öğrencilere robotların yaptığı işler ve bu işleri nasıl yapabildikleri sorulacak, cevaplar sınıfta tartışılacak, daha etkileşimli bir ortam sağlanacaktır.

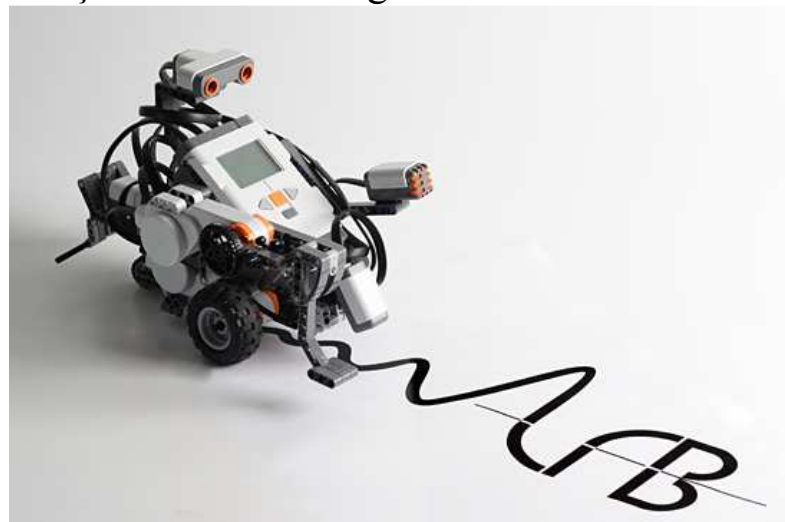

Figure E.1 Yaz1 yazan robot 


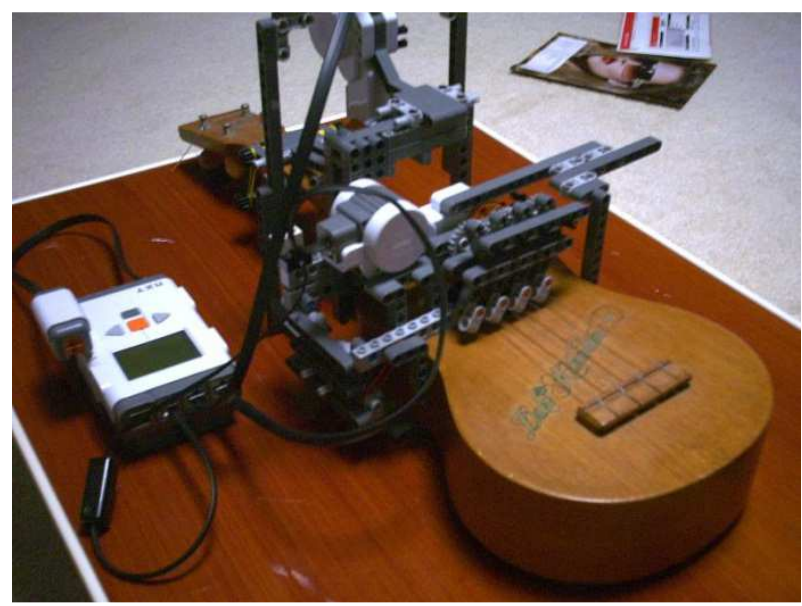

Figure E.2 Gitar çalan robot

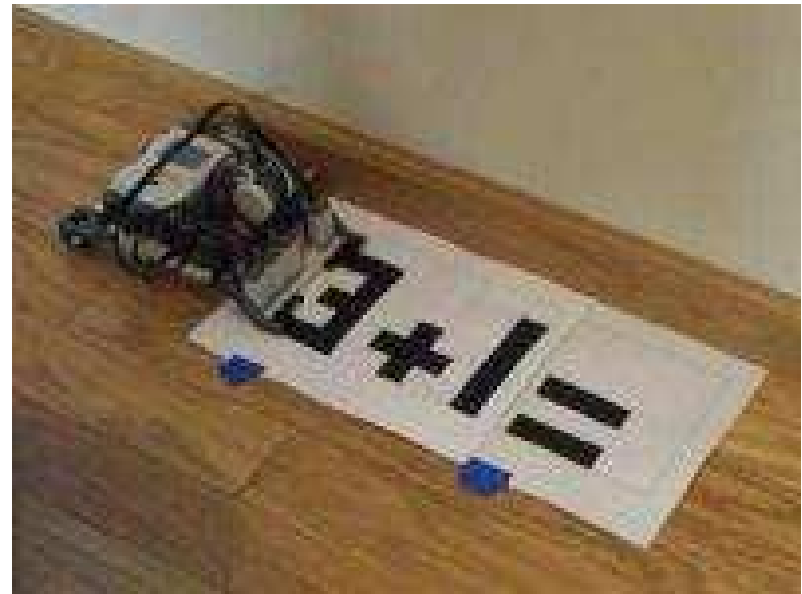

Figure E.3 Matematik problemi çözen robot

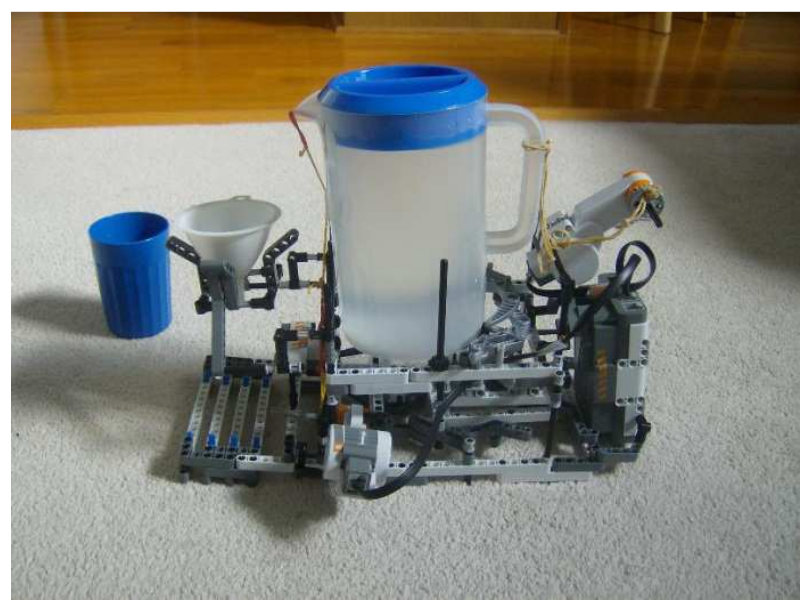

Figure E.4 Su dolduran robot

"Vol.i" filminin bir kısmının izlenmesi ve tartışma. Vol.i filminin bir kısmı seyredilecek ve ardından film üzerine tartışma yapılacaktır. Bu aktivitede robot ve toplum ilişkisi, robotlardaki zeka kavramı incelenecektir.

Robotlar üzerine tartışma. Örnek robotların gösteriminden sonra öğrenciler 2 kişiden 
oluşan gruplara ayrılarak hayallerindeki robotu/robotları masa başında pastel boyalarla çizmeleri istenecektir. Daha sonra her bir grup çizdikleri resmi diğer arkadaşlarıyla paylaşılacaktır.

Lego Mindstorms ortamına giriş ve algoritma. Öğrencilere Lego Mindstorms ortamının donanımsal ve yazılımsal bileşenleri tanıtılacaktır. Sınıfta basit bir robot geliştirerek robotun nasıl inşa edildiği, yazılımın kullanılarak robotun nasıl programlandığı, programların robota nasıl aktarıldığı ve robotun nasıl bu programı çalıştırıldığı gösterilecektir. Bu etkinlikte Lego Mindstorms yazılımının kullanımına yönelik detaylı bilgiler verme yerine baştan sona bir robotun nasıl yapıldığı bağlam (context) içinde sunulacaktır. Robotu kontrol eden programların çalışma mantığını görünür kılmak ve somutlaştırmak için drama tekniği kullanılacaktır. Bu drama tekniğinde, normalde dijital ortamda çalışan robot programlama süreci öğrencilerin rol aldığı bir sahnede canlandırılacaktır. Bu bağlamda, bir öğrenci grubu programcı rolünü üstlenecektir. Programcılar robotun belirli bir işi yapması için gereken komutları belirleyeceklerdir. Bir başka öğrenci, grubun yazdığı programları robota okuyup aktaracaktır. Robot rolü verilen başka bir öğrenci de kendisine iletilen komutları aynen sırasıyla yapacaktır. Robot aktarılan komutları yorum katmadan birebir uygulayacağı için grubunun hazırladığı programın ne kadar doğru olduğu tüm sınıf tarafından gözlemlenecektir. Programcıların robotu yeniden programlamalarına izin verilerek hatalarını düzeltmeleri sağlanacaktır. Başka problemlerde dramaya katılmayan öğrencilerin rol almaları sağlanarak tüm sınıfın dramada aktif olarak yer alması teşvik edilecektir. Eğitmen robotların ak sakallı dedesi rolünü oynayacak ve öğrencilere gerektiğinde yol gösterecektir. Drama etkinliğinin daha başarılı olması ve öğrencilerin konuyu daha iyi idrak edebilmeleri için aktivitenin başında eğitimciler katılımcılara drama etkinliğine bir örnek göstereceklerdir.

İlk robotumu yapıyorum aktivitesi. Gruplara robot setleri verilerek öğrencilerin robotu oluşturan parçaları incelemelerine izin verilir. Bu sayede öğrencilerin robot setlerini keşfetmeleri desteklenir. Gruplara, Lego Mindstorms kitapçığı verilerek bu kitapçıtaki yönergelere göre robotu oluşturmaları istenir. 


\section{E.2 The Second Day}

Etkinlik Tarihi (Gün/Ay/Yıl): 26/01/2010

Etkinliğin Adı: Robotun Tekerleğinin Çapı ve Kat Ettiği Mesafe

Hedef Kitle: İlköğretim 6. sinıflar

Etkinliği yaptıracak kişi(ler):

\section{Takım koçları:}

Etkinliğin Amacı: Öğrenci gruplarına robotlarının belirli bir mesafe (2 metre gibi) kadar yol alması görevi vererek ölçme, uzunluk ve denklemler gibi matematik konularında aşağıda belirtilen kazanımları sağlamak ve bu konuların gerçek hayatta nasıl işe yaradıklarını görünür kılmak.

\section{Ele Alınan Konunun İlköğretim Matematik Programındaki Yeri}

\begin{tabular}{|l|l|}
\hline Öğrenme Alanı & Kazanımlar \\
\hline Uzunlukları ölçme & $\begin{array}{l}\text { Uzunluk ölçme birimlerini açıklar ve } \\
\text { birbirine dönüştürür. }\end{array}$ \\
& $\begin{array}{l}\text { Düzlemsel şekillerin çevre } \\
\text { uzunluklarını strateji kullanarak tahmin } \\
\text { eder. }\end{array}$ \\
& Düzlemsel şekillerin çevre uzunlukları \\
& ile ilgili problemleri çözer ve kurar. \\
\hline & Eşitliğin korunumunu modelle gösterir \\
& ve açılar. \\
& Denklemi açılar, problemlere uygun \\
& denklemleri kurar. \\
& Birinci dereceden bir bilinmeyenli \\
Eşitlik ve denklem & denklemleri çözer. \\
\hline \multirow{3}{*}{ Dönüş̧üm Geome hareketini açıklar. } \\
& 2. Bir şeklin öteleme sonunda oluşan \\
& görüntüsünü inşa eder. \\
\hline
\end{tabular}

Etkinliğin Konusu: Etkinliğin konusu ilköğretim 6. sınıf programında yer alan uzunlukları ölçme, eşitlik ve denklem ve dönüşüm geometrisidir. Bu soyut konuların somut bir şekilde anlatmak ve bu konuların gerçek hayatta nasıl işe yaradığını göstererek öğrencilerin matematik konularına olan tutumlarını geliştirmek için robotların programlandığı probleme dayalı öğrenme yoluyla etkinlik sunulacaktır.

\section{Etkinliğin Süresi:}

$\begin{array}{ll}\text { 09:30 }-10: 20 & \text { Problemin açıklanması ve drama } \\ \text { 10:20 - 10:30 } & \text { Ara } \\ \text { 10:30 - 11:20 } & \text { Robotun programlanması } \\ \text { 11:20 - 11:30 } & \text { Ara }\end{array}$


$11: 30-12: 20$

Denklemler

12:20 - 13:30

$13: 30-14: 20$

$14: 20-14: 30$

$14: 30-15: 20$

$15: 20-15: 30$

$15: 30-16: 20$
Yol, tekerleğin çevresi ve attığı turu arasındaki ilişki,

Öğle yemeği

Ölçü birimlerinin birbirine dönüşümü

Ara

Çevre uzunluğu

Ara

Yarışma, Grup sunumları, Özet

\section{Kullanılacak Malzemeler:}

\section{Projeksiyon cihazı}

Her bir grup için 3 farklı boyutta robot tekerlek seti, bir adet mezura (şerit metre), çalışma kağıdı, Lego Mindstorms seti ve bilgisayar.

Etkinliğin Nasıl Yapıldığı (Rehber sayısı, katılımcı sayısı, senaryolaştırılmış ayrintılı uygulama planı vs.):

Rehber sayısi: 3

Katılımcı sayısi: 24 (6 grup)

Problemin açıklanması ve drama. Öğrencilere bir güvenlik robotu geliştirmeleri istenir. Bu robot, 2 metre boyundaki bir kapıda düzenli olarak gidip gelecektir. Öğrencilerin problemi daha net bir şekilde anlamaları için problem drama şeklinde anlatılır. Bu etkinlik sadece robotun 2 metre ileri gitmesini kapsamaktadır. Robotun geri dönmesi başka etkinliklerde sağlanacaktır. Öğrencilere, "robotun kat etmesi gereken mesafe ile tekerleğinin çevresi arasında bir ilişki olabilir mi" sorusu yöneltilir. Cevaplar sınıfta tartışılır. Öğrencilerin öne sürdükleri fikirleri test etmeleri için aşağıdaki deneyler yapılır.

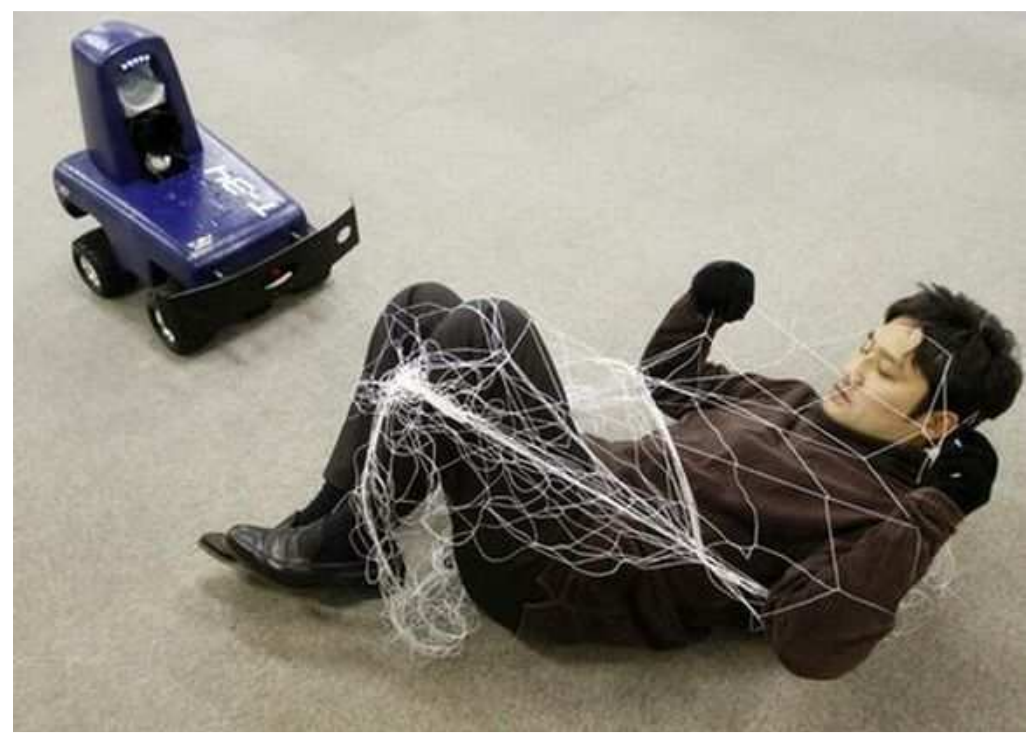

Figure E.5 Güvenlik robotu hırsızı yakalarken

Robotun ileri hareket etmesi için programlanması. Öğrencilere yazılımı kullanarak robotu programlamaları, bilgisayardaki programı robota aktarmayı ve son olarak da robota aktarılmış programı çalıştırmaları gösterilir. Robotun ileri doğru hareket etmesi gereken komutlar öğrencilere projeksiyon cihazında sunulur. 
Yol, tekerleğin çevresi ve attığ turu arasındaki ilişki. Her bir öğrenci grubuna 3 farklı boyutta robot tekerleği, bir adet Lego Mindstorms seti, mezura ve çalışma kağıdı verilir. Gruplar sırayla değişik boydaki tekerlek setlerini robotlarına takarlar. Deneme yanılma yoluyla robotlarının $50 \mathrm{~cm}$ yol kat etmesini sağlamaya çalışırlar. Her bir tekerlek için bulunan tur sayısı çalışma kağıdına yazılır.Öğrencilere, robotun aldığı yol, tekerleğinin çevresi ve attığı tur arasında bir ilişki olup olmadığı sorusu sorulur. Gruplar önce kendi aralarında bu soruyu tartışır. Sonra grupların cevapları sinıfta tartışılır.

Denklemler. Gruplara yol, çevre ve tur arasındaki ilişkiyi gösteren denklemi yazmaları istenir. Gruplar ellerindeki verileri birbirleri arasında değiştirirler. Her grup, önerdiği denklemin doğruluğu diğer grubun verilerini kullanarak sınar. Doğru cevap (denklem) sınıfta tartışılır. Bu denklemden her bir tekerleğin çevresi hesaplanır.

Ölçü birimlerinin birbirine dönüşümü. Öğrencilere bu sefer en büyük tekerlek takıldığında robotun 2 metre ilerlemesi için kaç tur atması gerektiği, 2 metrenin kaç santim ettiği sorulur. Cevapların doğruluğunu ölçmek için grupların mezura kullanmaları istenir. Hangi cevabın doğru olduğu sınıfça tartışılır.

Çemberin çevre uzunluğu. Öğrencilere, tekerleğin çevresi ile çapı arasında bir ilişkinin olup olmadığını test etmeleri istenir. Öğrenciler 3 tekerleğin çevresini ve çapını mezura ile ölçüp, ölçüm sonucunu çalışma kağıtlarına yazarlar. Grupların bu ilişkiyi gösteren denklemi bulmaları istenir. Gruplar ellerindeki verileri birbirleri arasında değiştirirler. Her grup, önerdiği denklemin doğruluğu diğer grubun verilerini kullanarak sınar. Doğru cevap (denklem) sınıfta tartışılır.

Yarışma ve Grup sunumları. Grupların kendilerine verilen görevi yani robotlarını 2 metre ileri gitmesini sağlamaları istenir. Her bir gruba tek bir hak verilerek, robotlarının belirtilen mesafe kadar ileri gidip gitmediğini ölçer. Her bir tekerlek için ayrı yarışma yapılır. Hataların sebepleri çalışma kağıdındaki ilgili yere yorumlamaları istenir. Hataların gruplar tarafından keşfedilip çözmeleri istenir. Gerektiğinde eğitmenler gruplara yardım ederler. Son olarak, tüm gruplar kendilerine verilen projeyi sınıfın önünde sunarlar. Bu kapsamda gruplar hem kendi robotlarının nasıl çalıştığını gösterirler, hem de öğrendikleri matematik konularını yorumlarlar.

Özet. Kapanışta, eğitmenler bu etkinlikte işlenen konuları özet bir şekilde tekrar ederler ve matematikte işlenen bu konuların gerçek hayatta nasıl işe yaradıklarını örnek verip anlatırlar. 


\section{E.3 The Third Day}

Etkinlik Tarihi (Gün/Ay/Yıl): 27/01/2010

Etkinliğin Adı: Geometri ve Robotun Dönmesi

Hedef Kitle: İlköğretim 6. sinıflar

Etkinliği yaptıracak kişi(ler):

\section{Takım koçları:}

Etkinliğin Amacı: Bu etkinliğin amacı daha önceki etkinliklerde tasarlanmış olan güvenlik robotunun bazı matematiksel bilgi ve beceriler 1şı̆̆ında 180 derece (geri) dönmesini sağlamaktır. Bu etkinlik yapılırken öğrencilerin aşağıda belirtilen öğrenme alanları ve kazanımları edinmeleri beklenecektir.

Ele Alınan Konunun İlköğretim Matematik Programındaki Yeri

\begin{tabular}{|c|c|}
\hline Öğrenme Alanı & Kazanımlar \\
\hline Uzunlukları ölçme & $\begin{array}{l}\text { 1. Uzunluk ölçme birimlerini } \\
\text { açıklar ve birbirine dönüştürür. } \\
\text { 2. Düzlemsel şekillerin çevre } \\
\text { uzunluklarını strateji kullanarak } \\
\text { tahmin eder. } \\
\text { 3. Düzlemsel şekillerin çevre } \\
\text { uzunlukları ile ilgili problemleri } \\
\text { çözer ve kurar. }\end{array}$ \\
\hline Eşitlik ve denklem & $\begin{array}{l}\text { 1. Eşitliğin korunumunu modelle } \\
\text { gösterir ve açıklar. } \\
\text { 2. Denklemi açılar, problemlere } \\
\text { uygun denklemleri kurar. } \\
\text { 3. Birinci dereceden bir } \\
\text { bilinmeyenli denklemleri çözer. }\end{array}$ \\
\hline Dönüşüm Geometrisi & $\begin{array}{l}\text { 1. Dönme hareketini açıklar. } \\
\text { 2. Düzlemde bir nokta etrafında ve } \\
\text { belirtilen bir açıya göre şekilleri } \\
\text { döndürerek çizimini yapar. }\end{array}$ \\
\hline Çember ve Daire & $\begin{array}{l}\text { 1. Çemberin özelliklerini belirler ve } \\
\text { çember modeli inşa eder. } \\
\text { 2. Çemberin düzlemde ayırdığı } \\
\text { bölgeleri belirler. } \\
\text { 3. Çember ile doğrunun ilişkisini } \\
\text { belirler. } \\
\text { 4. Çember veya dairede merkez açı }\end{array}$ \\
\hline
\end{tabular}




\begin{tabular}{|l|l|}
\hline & $\begin{array}{l}\text { ve çevre açı ile bu açıların } \\
\text { gördüğü yayları belirler. }\end{array}$ \\
5. Aynı yayı gören merkez açıını \\
ölçüsü ile çevre açının ölçüsü \\
arasındaki ilişkiyi belirler.
\end{tabular}

\section{Etkinliğin Konusu:}

$\mathrm{Bu}$ etkinliğin konusunu ilköğretim matematik programında yer alan Uzunlukları ölçme, Eşitlik ve denklem, Dönüşüm Geometrisi ve Çember ve Daire konuları oluşturmaktadır. Bu soyut konuların somut bir şekilde anlatmak ve bu konuların gerçek hayatta nasıl işe yaradığını göstererek öğrencilerin matematik konularına olan tutumlarını geliştirmek için robotların programlandığı probleme dayalı öğrenme yoluyla etkinlik sunulacaktır.

\section{Etkinliğin Süresi:}

\begin{tabular}{|c|c|}
\hline $09: 30-10: 20$ & Problemin açıklanması ve drama \\
\hline $10: 20-10: 30$ & Ara \\
\hline $10: 30-11: 20$ & Robotun geri dönmesi için programlanması \\
\hline $11: 20-11: 30$ & Ara \\
\hline $11: 30-12: 20$ & Yol, tekerleğin çevresi ve attığı turu arasındaki ilişki \\
\hline $12: 20-13: 30$ & Öğle yemeği \\
\hline $13: 30-14: 20$ & Denklemler \\
\hline $14: 20-14: 30$ & Ara \\
\hline $14: 30-15: 20$ & Denklemler \\
\hline $15: 20-15: 30$ & Ara \\
\hline $15: 30-16: 20$ & Yarışma, Grup sunumları, Özet \\
\hline
\end{tabular}

\section{Kullanılacak Malzemeler:}

Projeksiyon cihazı

Her bir grup için robot seti, bir adet mezura, çalışma kağıdı, Lego Mindstorms seti ve bilgisayar.

\section{Etkinliğin Nasıl Yapıldığı (Rehber sayısı, katılımcı sayısı, senaryolaştırılmış ayrintılı uygulama planı vs.):}

Rehber sayısi: 3

Katılımcı sayısı: 24 (6 grup)

Problemin açıklanması ve drama. Öğrencilerden daha önceki etkinliklerde geliştirilmiş olan güvenlik robotunun geri dönmesini sağlamaları istenir. Robotun nasıl döneceğini öğrencilere kavratabilmek için bir drama aktivitesi yapılır. Bu drama etkinliğinde iki katılımcı robotun tekerleği rolünü üstlenirler. Robotun 180 derece dönmesi için bir öğrencinin sabit kalıp, diğer öğrencinin dairesel bir yol üzerinde hareket etmesi gerekir. Öğrenciler arasındaki mesafe artığında hareket eden öğrencinin daha fazla yol kat etmesi gerektiği, bir başka deyişle yarı çapı daha büyük bir dairenin çevresinde yol alması gerektiği keşfedilir.

Robotun geri dönmesi için programlanması. Bir tekerleğin hareket etmeyerek tek bir tekerleğin dönmesi öğrencilere projeksiyon cihazında gösterilir. Öğrenciler deneme yanılma yoluyla robotlarını 180 derece döndürmek için tek bir tekerleğin kaç tur 
attığını bulurlar. Bu değeri çalışma kağıdına yazarlar. İki tekerlek arasındaki mesafe 2 defa değiştirilir. Her bir durumda robotun 180 derece dönmesi için tek bir tekerleğin kaç tur attığı bulunur.

Yol, tekerleğin çevresi ve attı̆̆ tur arasındaki ilişki. Bir önceki aktivitede yol, tekerleğin çevresi ve attığı tur arasındaki ilişki incelenmişti. Ayrıca, bir önceki aktivitede hesaplanan tekerleklerin çevresi ile tekerleğin attığ 1 tur çarpilarak tekerleğin kat ettiği yol hesaplanır. İki tekerlek arasındaki farklı mesafeler ile tek bir tekerleğin kat ettiği yol arasındaki ilişki tartışılır.

Denklemler. Gruplardan bu ilişkiyi açıklayan denklemi bulmaları istenir. Aşağıda doğru denklem yazılmıştır.

Robotun dönüş açısı / $360=$ tek bir tekerleğin kat ettiği yol / dairenin çevresi (yarıçap = iki tekerlek arasındaki mesafe)

Yarışma ve Grup sunumları. Grupların kendilerine verilen görevi yani robotlarını 2 metre ileri gidip geri dönmesi istenir. Her bir gruba tek bir hak verilerek, robotlarının belirtilen mesafe kadar ileri gidip gitmediğini ve 180 derece dönüp dönmediğini ölçer. Başlangıç noktasına en yakın mesafede duran grup yarışmayı kazanır. Tekerler arasındaki 3 farklı mesafe için ayrı ayrı 3 yarışma düzenlenir. Hataların sebepleri çalışma kağıdındaki ilgili yere yorumlamaları istenir. Hataların gruplar tarafından keşfedilip çözmeleri istenir. Gerektiğinde eğitmenler gruplara yardım ederler. Son olarak, tüm gruplar kendilerine verilen projeyi sınıfın önünde sunarlar. Bu kapsamda gruplar hem kendi robotlarının nasıl çalıştığını gösterirler, hem de öğrendikleri matematik konularını yorumlarlar.

Özet. Kapanışta, eğitmenler bu etkinlikte işlenen konuları özet bir şekilde tekrar ederler ve matematikte işlenen bu konuların gerçek hayatta nasıl işe yaradıklarını örnek verip anlatırlar. 


\section{E.4 The Fourth Day}

Etkinlik Tarihi (Gün/Ay/Yıl): 28/01/2010

Etkinliğin Adı: Robotun Hızının Bulunması

Hedef Kitle: İlköğretim 6. sınıflar

Etkinliği yaptıracak kişi(ler):

\section{Takım koçları:}

\section{Etkinliğin Amacı:}

Öğrenciler 4 ve 5 . sinıflarda kuvvetin ne olduğu, cisimlerin hareketlerine veya şekillerine olan etkileri ve kuvvet çeşitleriyle ilgili bilgileri almıştır. Bu aşamadan sonra öğrenciler, bazı cisimlerin hızlarını hesaplayabilmelidir. İşte bu etkinlikte de öğrenci gruplarının belirli bir mesafede sabit hızla farklı tasarımlardaki robotların hızlarını hesaplamaları istenecektir. Bu etkinlik yoluyla öğrencilerin aşağıda belirtilen kazanımları edinmelerinin yanı sıra bu konuların günlük yaşamda nasıl işe yaradığını anlamaları sağlanmaya çalışılacaktır.

Ele Alınan Konunun İlköğretim Fen ve Teknoloji Öğretim Programındaki Yeri: Sinıf Seviyesi : 6. Sinıf Öğrenme Alanı : Fiziksel Olaylar - Basit M

2. Ünite : Kuvvet ve Hareket

İlgili kazanımlar

1.1. Cismin aldığı yolu ve bu yolu ne kadar zamanda aldığını ölçer (BSB-22, 23).

1.2. Alınan yolu ve geçen zamanı kullanarak cismin süratini hesaplar.

1.3. Sürat birimlerini ifade eder ve kullanır (BSB-24).

1.4. Alınan yol, geçen zaman ve sürat arasındaki ilişkiyi açıklar ve farklı durumlar için uygular (BSB-30).

1.5. Bir cismin aldığı yol ile geçen zaman arasındaki ilişkiyi grafikle gösterir ve grafiği yorumlar.

\section{Etkinliğin Konusu:}

Etkinliğin konusunu ilköğretim 6. sınıf programında Fiziksel Olaylar öğrenme alanının Kuvvet ve Hareket Ünitesi'nin hız-yol-zaman konuları oluşturmaktadır. Etkinlik ayrıca yine ilköğretim 6.sınıf matematik programında yer alan uzunlukları ölçme, eşitlik ve denklem ve dönüşüm geometrisini de içermektedir. Bu soyut konular somut bir şekilde anlatılarak ve gerçek yaşamla ilişkisi kurularak öğrencilerin fen ve matematik konularına olan tutumları geliştirilecektir. Etkinliklerde probleme dayalı öğrenmeye dayalı aktiviteler sunulacaktır.

\section{Etkinliğin Süresi:}

$\begin{array}{ll}\text { 09:30 }-10: 20 & \text { Problemin açıklanması } \\ \text { 10:20 - 10:30 } & \text { Ara } \\ \text { 10:30 - 11:20 } & \text { Uzunluk ölçümü, Robotun programlanması } \\ \text { 11:20 - 11:30 } & \text { Ara }\end{array}$


$11: 30-12: 20$

Alınan yol ve zaman arasındaki ilişki, dişli çarklar, Formüller

$12: 20-13: 30$

Öğle yemeği

13:30 - 14:20 Robotların hızlarının hesaplanması, değişik dişlilerle tekrar tasarlanan robotların hızlarının ölçümü

14:20 - 14:30 Ara

14:30 - 15:20 Elde edilen verilerin bilgisayar ortamında grafiklerinin

hazırlanmasi

15:20 - 15:30 Ara

15:30 - 16:20 Yarışma, Grup sunumları, Özet

\section{Kullanılacak Malzemeler:}

- Projeksiyon cihaz1,

- Her bir grup için robot seti,

- Bir adet mezura,

- Kronometre,

- Çalışma kâğıdı,

- Grafik Kağıdı,

- Lego Mindstorms seti,

- Bilgisayar ve

- Yazıc1.

Etkinliğin Nasıl Yapıldığı (Rehber sayısı, katılımcı sayısı, senaryolaştırılmış ayrintılı uygulama planı vs.):

Rehber sayıst: 3

Katılımcı sayısı: 24 (6 grup)

Problemin açıklanması: Bir önceki etkinlikte yaptığımız güvenlik robotu hırsızları yakalamak

için bir ağ atmaktadır. Robotunuzun hırsızları yakalayabilmesi için en azından hırsızların koşma hızına yakın bir hızda hareket etmesi gerekmektedir. Bu nedenle bu etkinlikte bir robotun hızını nasıl ölçeceğinizi öğrenmenin yanı sıra robotunuzun değişik hızlarda hareket etmesini sağlayıcı süreçleri öğrenmeniz gerekecektir. Size verilen robotu kullanarak aşağıdaki etkinlikleri yapınız.

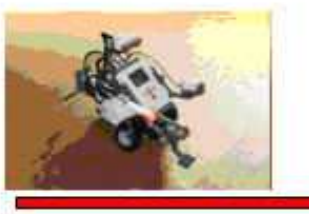

A

A ile $\mathrm{C}$ arasındaki uzaklık 4 metredir.

Robotunuz sabit hızla hareket etmektedir.

$\mathrm{AB}$ arasındaki uzaklık AC arasındaki uzaklığın 4 katıdır.

Bu bilgilerden yararlanarak, aşağıdaki soruların cevabını robotunuzu kullanarak bulunuz ve aşağıdaki tabloya yazınız 
A noktasındaki robotun $\mathrm{C}$ noktasına varması için geçen süre ne kadardır?

A noktasındaki robotun B noktasına varması için geçen süre ne kadardır?

A noktasından hareket eden robotun hızı $\mathrm{kaç} \mathrm{m} / \mathrm{sn}$ ve $\mathrm{kaç} \mathrm{km} / \mathrm{saat}$ 'tir.Robotunuz için 3 farklı deneme yapınız ve ortalama değerleri bulunuz ve aşağıdaki tabloya yazınız.

Tablo 1. A Noktasından hareket eden robot için veri tablosu

\begin{tabular}{|c|c|c|c|c|c|c|c|}
\hline \multicolumn{6}{|c|}{ C Noktasına gelmesi için geçen süre (sn) } & \multicolumn{3}{|c|}{$\begin{array}{c}\text { B noktasına gelmesi için geçen süre } \\
(\mathrm{sn})\end{array}$} \\
\hline $\begin{array}{c}\text { 1.Dene } \\
\text { me }\end{array}$ & $\begin{array}{c}\text { 2.Dene } \\
\text { me }\end{array}$ & $\begin{array}{c}\text { 3.Dene } \\
\text { me }\end{array}$ & $\begin{array}{c}\text { Ortala } \\
\text { ma }\end{array}$ & $\begin{array}{c}\text { 1.Dene } \\
\text { me }\end{array}$ & $\begin{array}{c}\text { 2.Dene } \\
\text { me }\end{array}$ & $\begin{array}{c}\text { 3.Dene } \\
\text { me }\end{array}$ & $\begin{array}{c}\text { Ortala } \\
\text { ma }\end{array}$ \\
\hline & & & & & & & \\
\hline
\end{tabular}

Yukarıdaki tablodan elde ettiğiniz değerler için yol - zaman grafiği çiziniz ve bu grafik üzerinde tartışmalar yapınız.

Yukarıdaki tablodan elde ettiğiniz ortalama değerleri aşağıdaki tabloya yazarak her iki robotun hızını hesaplayınız.

\begin{tabular}{|c|l|l|l|}
\hline Robot & A - B Uzaklığ (m) & Geçen Süre (s) & $\begin{array}{l}\text { Hız= A-B } \\
\text { Uzaklığ / Geçen } \\
\text { Süre }\end{array}$ \\
\hline $\begin{array}{c}\text { A Noktasındaki } \\
\text { Robot }\end{array}$ & & & \\
\hline
\end{tabular}

\section{Robotunuzun Hızının değiş̧irilmesi}

Bu etkinlik için robotunuzun motor gücünü değiştirerek hızını tekrar hesaplayınız.

Tablo 1. A Noktasından hareket eden robot için veri tablosu

\begin{tabular}{|c|c|c|c|c|c|c|c|}
\hline \multicolumn{5}{|c|}{$50 \%$ Güç } & \multicolumn{4}{c|}{$100 \%$ Güç } \\
\hline $\begin{array}{c}\text { 1.Dene } \\
\text { me }\end{array}$ & $\begin{array}{c}2 . \text { Dene } \\
\text { me }\end{array}$ & $\begin{array}{c}3 . \text { Dene } \\
\text { me }\end{array}$ & $\begin{array}{c}\text { Ortala } \\
\text { ma }\end{array}$ & $\begin{array}{c}1 . \text { Dene } \\
\text { me }\end{array}$ & $\begin{array}{c}2 . \text { Dene } \\
\text { me }\end{array}$ & $\begin{array}{c}3 . \text { Dene } \\
\text { me }\end{array}$ & $\begin{array}{c}\text { Ortala } \\
\text { ma }\end{array}$ \\
\hline & & & & & & & \\
\hline
\end{tabular}

Yukarıdaki tablodan elde ettiğiniz değerler için yol - zaman grafiği çiziniz ve bu grafik üzerinde tartışmalar yapınız.

Yukarıdaki tablodan elde ettiğiniz ortalama değerleri aşağıdaki tabloya yazarak her iki robotun hızını hesaplayınız.

\begin{tabular}{|c|l|l|l|}
\hline Robot & A - B Uzaklığı (m) & Geçen Süre (s) & $\begin{array}{l}\text { Hız= A-B } \\
\text { Uzaklığı / Geçen } \\
\text { Süre }\end{array}$ \\
\hline $50 \%$ Güç & & & \\
\hline
\end{tabular}


\begin{tabular}{|l|l|l|l|}
\hline $100 \%$ Güç & & & \\
\hline
\end{tabular}

\section{Etkinlik ile ilgili açıklamalar}

$\mathrm{Bu}$ etkinlikte öğrenciler, ilk olarak bir doğru üzerinde sabit süratle hareket eden cisimlerin aldıkları yolları zamana bağlı ölçerek hızlarını hesaplar, alınan yol ve geçen zaman grafiklerini yorumlar.

Robotun ileri hareket etmesi için programlanması: Robotu programlamaları için gereken komutlar öğrencilere projeksiyon cihazında sunulur. Motora değişik çapta dişlilerin bağlanması ve bunlar arasındaki oranlar, matematiksel bilgiler ışığında öğrencilere sunulur.

Uzunluk ölçümü: Öğrencilere mezura verilerek 4 metrelik bir çizgi çizmeleri ve A $\mathrm{C}$ yol mesafesini hesapladıktan sonra yine mezura ile bu mesafeyi işaretlemeleri istenir. Buradaki basit matematik probleminden yararlanarak $A C$ ve $C B$ arasindaki mesafeleri de öğrencilerin bulması istenir.

Yol - Zaman - Hiz ilişkisi: Öğrenciler A noktasından hareket eden robotun C noktasına ve B noktasına ulaşması için ve motora değişik dişlilerin takılması durumunda geçen süreyi kronometre ile ölçmeleri istenir. Daha sonra elde ettikleri verileri Excel programı ile grafiğe dönüştürüp, bu grafiklerin yorumlanması istenir. Buradaki grafiğin sabit bir çizgi çıkması beklenmelidir. Son tabloda verileri yerine yazarak her iki robotun hızını bulmaları istenir.

Ölçü birimlerinin birbirine dönüşümü: Öğrencilerin robot hızlarını değişik ölçü birimlerine çevirmeleri istenir. Örneğin $\mathrm{m} / \mathrm{s}, \mathrm{km} / \mathrm{s}$ v.s

Yarışma ve Grup sunumlart: Grupların kendilerine verilen görevi yani belirli hızda hareket eden robot yapmaları istenir. Kronometre ile ölçülen sabit bir süre (30 saniye gibi) boyunca robotun belirtilen hızda gitmesi amaçlanmaktadır. Yarışma 3 farklı hız için tekrarlanır. Hataların sebepleri çalışma kağıdındaki ilgili yere yorumlamaları istenir. Hataların gruplar tarafından keşfedilip çözmeleri istenir. Gerektiğinde eğitmenler gruplara yardım ederler. Son olarak, tüm gruplar kendilerine verilen projeyi sınıfın önünde sunarlar. Bu kapsamda gruplar hem kendi robotlarının nasıl çalıştığını gösterirler, hem de öğrendikleri fen ve matematik konularını yorumlarlar. Özet. Kapanışta, eğitmenler bu etkinlikte işlenen konuları özet bir şekilde tekrar ederler ve matematikte işlenen bu konuların gerçek hayatta nasıl işe yaradıklarını örnek verip anlatırlar. 


\section{E.5 The Fifth Day}

Etkinlik Tarihi (Gün/Ay/Yıl): 29/01/2010

Etkinliğin Adı: Sesin Yansıması, Sensör Verilerinden Robotların Engelden Sakınması ve Nesneleri Tanıması

Hedef Kitle: İlköğretim 6. sinıflar

Etkinliği yaptıracak kişi(ler):

\section{Takım koçları:}

Etkinliğin Amacı: Gruplara robotlarının engelden sakınması ve nesneleri tanıması görevleri vererek ses dalgalarının maddelerle etkileşimini (yansıma, soğurulma ve geçme) gibi fen ve teknoloji konuları ile uzunluk ve denklemler gibi matematik konularında aşağıda belirtilen kazanımları gerçekleştirmek ve bu konuların gerçek hayatta nasıl işe yaradıklarını görünür kılmak.

\section{Ele Alınan Konunun İlköğretim Programındaki Yeri}

\begin{tabular}{|c|c|}
\hline Öğrenme Alanı & Kazanımlar \\
\hline Iş1k ve ses & $\begin{array}{l}\text { Sesin her yönde dalgalar halinde } \\
\text { yayıldığını fark eder (BSB-1). } \\
\text { Sesin bir engel ile karşılaştığında } \\
\text { yansıdığını deney ile keşfeder (BSB-1, } \\
8,17 \text { ) } \\
\text { Bilim ve teknolojide sesin yansıması } \\
\text { olayından nasıl yararlanıldığına } \\
\text { örnekler verir (FTTÇ-9, 16, 17; TD-3). } \\
\text { Madde ile karşılaşan sesin } \\
\text { soğurulabileceğini fark eder (BSB-1). } \\
\text { Farklı maddelerin sesi farklı } \\
\text { soğurduğunu fark eder (BSB-1, 6). } \\
\text { Ses yalıtımında ve yankı oluşumunu } \\
\text { önlemede, kullanılan malzemelerin sesi } \\
\text { iyi soğurduklarını fark eder (BSB-8, 30, } \\
\text { 31; FTTÇ-32). }\end{array}$ \\
\hline Eşitlik ve denklem & $\begin{array}{l}\text { Eşitliğin korunumunu modelle gösterir } \\
\text { ve açıklar. } \\
\text { Denklemi açıklar, problemlere uygun } \\
\text { denklemleri kurar. } \\
\text { Birinci dereceden bir bilinmeyenli } \\
\text { denklemleri çözer. }\end{array}$ \\
\hline
\end{tabular}

Etkinliğin Konusu: Etkinliğin konusu ilköğretim 6. sınıf fen ve teknoloji programında yer alan ışık ve ses ile matematik programında yer alan eşitlik ve 
denklemlerdir. Aktivitelerin daha etkileşimli bir şekilde yapılma suretiyle öğrencileri öğrenme sürecinde daha aktif bir konuma getirmek ve derslerde işlenen kuramların gerçek hayatta nasıl kullanılabileceğini göstermek için robotların programlandığ1 probleme dayalı öğrenme yoluyla etkinlikler gerçekleştirilecektir.

\title{
Etkinliğin Süresi:
}

09:30 - 10:20 Problemin açıklanması, Robotu programlamanın öğretilmesi

\author{
10:20 - 10:30 Ara \\ 10:30 - 11:20 Engellerden sakınma. Uzaklık, sesin hızı ve zaman arasındaki
}

ilișki

11:20-11:30 Ara

11:30 - 12:20 Nesnelerin ayırt edici özellikleri, Nesnelerin tanınması,

Yarışma

12:20 - 13:30 Öğle yemeği

$13: 30-14: 20$

14:20 - 16:20 ODTÜ Bilim ve Teknoloji Müzesine Gezi

\section{Kullanılacak Malzemeler:}

Projeksiyon cihazı

Her bir grup için bir adet mezura, çalışma kağıdı, Lego Mindstorms seti, bilgisayar, engel görevi görecek kitap

Etkinliğin Nasıl Yapıldığı (Rehber sayısı, katılımcı sayısı, senaryolaştırılmış ayrintılı uygulama planı vs.):

Rehber sayıst: 3

Katılımcı sayısı: 24 (6 grup)

Problemin açıklanması. Öğrenciler, daha önceki aktivitelerde bazı özelliklerini yaptıkları robotlarını geliştirmeleri istenir. Bu aktivitede, robota engelden sakınma ve belirli bir nesneyi tanıma nitelikleri eklenmesi gerekmektedir. Robotun görev aldığ güvenlik kapısında önüne insanlar çıkabilir. Robotun bu engellerle karşılaştığında durup geri dönmesi istenmektedir. Bunun yanında güvenlik kapısına bazen güvenlik kukaları bırakılmaktadır. Robotun bu kukalara tanıması gerekmektedir. Öğrencilere önce karanlık mağaralarda yarasaların duvarlara ve diğer yarasalara çarpmadan nasıl uçtukları sorulur. Cevaplar sınıfça tartışılır. Yarasanın bu özelliğinin robotlara uygulanabilip uygulanamayacağı hakkında öğrencilerin görüşleri dinlenir. Daha sonra, öğrencilerin gözlerini kapatmaları istenir ve ellerine bazı nesneler verilir. $\mathrm{Bu}$ nesnelerin tanınması istenir. Tanıma işlemini nasıl yaptıkları öğrencilere sorulur. Bunun, robotlara nasıl uygulanabileceği tartışılır. 

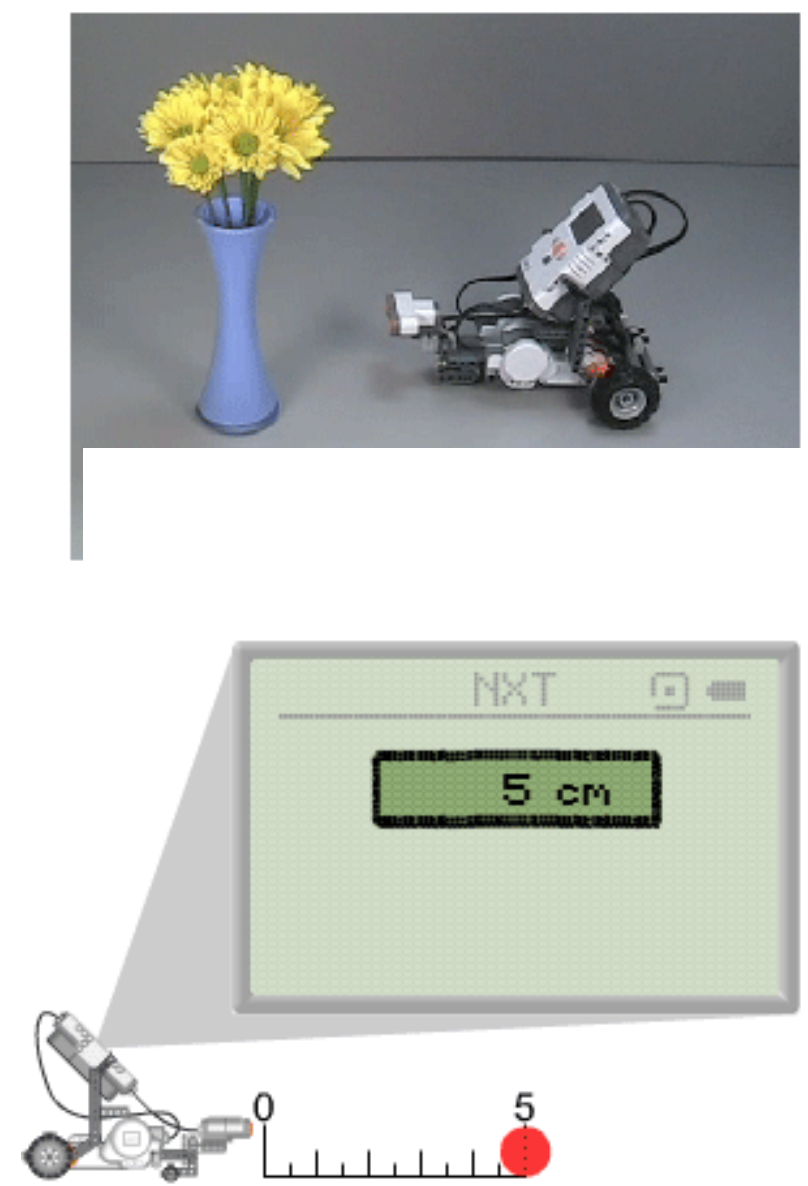

Figure E.6 Güvenlik robotu ultrasonik sensörü ile nesnelerin uzaklığını ölçerken

Robotu programlamanın öğretilmesi. Robotun uzaklığa duyarlı ultrasonik sensöründen verilerinin okunması için gereken komutlar öğrencilere projeksiyon cihazında sunulur.

Engellerden sakınma. Her bir öğrenci grubuna bir adet Lego Mindstorms seti, mezura, çalışma kağıdı verilir. Ayrıca engel olarak bir nesne verilir. Grupların robotlarının karşısına çıkan engel çıktığı zaman geri dönmesini programlaması istenir. Zorluk çeken gruplara destek verilir.

Uzaklık, sesin hızı ve zaman arasındaki ilişki. Önce uzaklık, sesin hızı ve zaman arasındaki ilişki grup içinde tartışılması istenir. Sonra gruplara bu ilişkiyi gösteren denklemi yazmaları istenir. Son olarak da öğrencilere, ultrasonik sensörün yaydığı sesin kaç saniyede renkli naylona çarpıp geri döndüğü sorulur Öğrenciler, naylon ile sensör arasındaki uzaklığını ve sesin hızını bilmektedir. Yapmaları gereken tek bilinmeyenli bu denklemi çözmektir. Grupların cevapları karşılaştırılır.

Nesnelerin ayırt edici özellikleri. Gruplara farklı renge sahip iki farklı renkte kitap verilir. Öğrencilerden robotlarının bu farklı renkteki kitapları nasıl ayırt edebileceği sorulur. 
Nesnelerin tanınması. Gruplara, robotlarının farklı renkteki kitapları tanıması için 1şık sensörünü nasıl kullanabilecekleri anlatılır. Daha sonra öğrenciler gerekli programı yazmaya koyulurlar. Eğitmenler bu süreçte öğrencileri yönlendirirler.

Yarışma ve Grup sunumları. Grupların kendilerine verilen görevi yani robotlarının karşısına bir engel çıkınca durup geri dönmesi ve farklı renkteki kitapları ayırt etmesi istenir. Yarışma 3 defa ayrı renklere sahip kitaplar için tekrarlanır. Tüm gruplar kendilerine verilen projeyi sınıfın önünde sunarlar. Bu kapsamda gruplar hem kendi robotlarının nasıl çalıştığını gösterirler, hem de öğrendikleri konuları yorumlarlar.

Özet. Kapanışta, eğitmenler bu etkinlikte işlenen konuları özet bir şekilde tekrar ederler ve okulda işlenen bu teorik konuların gerçek hayatta nasıl işe yaradıklarını örnek verip anlatırlar.

ODTÜ Bilim ve Teknoloji Müzesi’ne gezi. ODTÜ Bilim ve Teknoloji Müzesi'ne gezi düzenlenecektir. 


\section{E.6 The Sixth Day}

Etkinlik Tarihi (Gün/Ay/Yıl): 01/02/2010

Etkinliğin Adı: Robotların Çizgileri İzlemesi

Hedef Kitle: İlköğretim 6. sınıflar

Etkinliği yaptıracak kişi(ler):

\section{Takım koçları:}

\section{Etkinliğin Amacı:}

$\mathrm{Bu}$ etkinlikte robotların belirli bir çizgiyi izleyebilmeleri için gerekli tasarım ve programları yapmaları sağlanacaktır.

\section{Etkinliğin Konusu:}

$\mathrm{Bu}$ etkinliğin konusunu 1şı sensörleri oluşturmaktadır. Bu sensörlerin robotlara nasıl adapte edileceği ve nasıl programlanacağı öğretmenler tarafından anlatılacaktır. Öğrenciler için soyut konular somut bir şekilde anlatılarak ve gerçek yaşamla ilişkisi kurularak robotların günlük yaşamdaki ve endüstriyel alanlarda kullanım prensipleri anlatılmaya çalışılacaktır. Etkinliklerde probleme dayalı öğrenmeye dayalı aktiviteler kullanılacaktır.

\section{Etkinliğin Süresi:}
$09: 30-10: 20$
Problemin açıklanması
$10: 20-10: 30$
Ara
$10: 30-11: 20$
Robotun belli bir çizgide ilerlemesini sağlaması için gerekli programların yapilması
$11: 20-11: 30$
Ara
11:30 - 12:20 Belirli bir saha üzerinde robotun izleyeceği çizgilerin belirlenmesi ve 1şık sensörlerinin kullanılması
$12: 20-13: 30$
Öğle yemeği arasındaki ilişkilerin kurulması
$14: 20-14: 30$
Ara
$14: 30-15: 20$
Tasarlanan robotun denemesi
$15: 20-15: 30$
Ara
$15: 30-16: 20$
Yarışma, Grup sunumları, Özet

13:30 - 14:20 Robota 1ş1k sensörünün yerleştirilmesi ve robot-sensör

\section{Kullanılacak Malzemeler:}

- Projeksiyon cihazı,

- Siyah elektrik bandı

- Çalışma kâğıdı,

- Lego Mindstorms seti,

- Bilgisayar ve

- Yazici. 


\section{Etkinliğin Nasıl Yapıldığı (Rehber sayısı, katılımcı sayısı, senaryolaştırılmış ayrintılı uygulama planı vs.):}

Rehber sayısl: 3

Katılımcı sayısi: 24 (6 grup)

Problemin açıklanması: Bir haftalığına tatile çıkmayı planlıyorsunuz. Son iki hafta içerisinde ise evinizin bulunduğu bölgede çeşitli hırsızlık olaylarının yaşandığını duydunuz. Bir önceki etkinlikte hazırlamış olduğunuz güvenlik robotunun evinizde belli saatlerde ve belli bölgelerinde ses çıkararak dolaşmasını istiyorsunuz. Böylelikle hırsızların evin boş olmadığını anlayarak evinizde hırsızlık amacıyla girmemesini sağlayacaksınız. Bu nedenle krokisi aşağıda verilen evinizin içerisinde robotunuzun belli çizgileri izleyebilmesi için gerekli programlamayı yapmanız gerekmektedir.

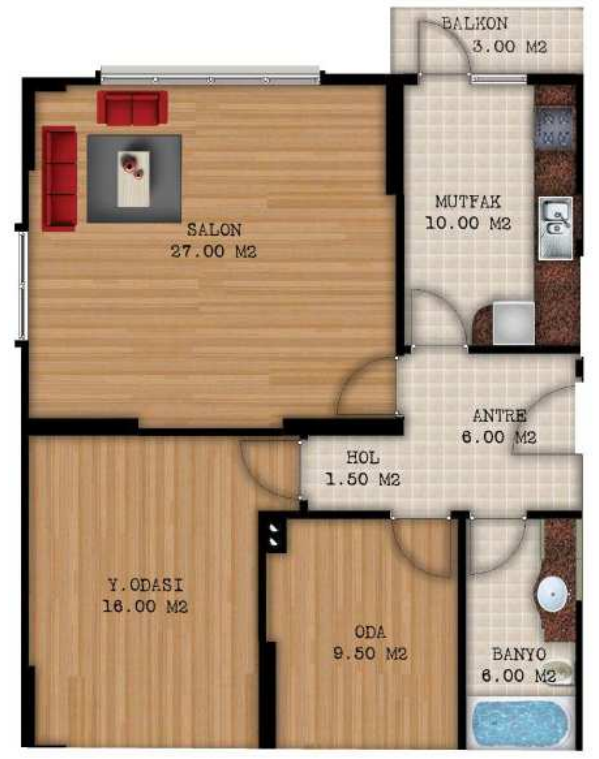

Figure E.7 Güvenlik robotu ev planı

Robotunuzun bütün odaları, mutfak ve banyoyu dolaşması gerekmektedir. Buna uygun çizgileri çizerek robotunuzun bu çizgiler üzerinde hareket etmesini sağlayınız.

\section{Etkinlik ile ilgili açıklamalar}

\section{Etkinlik öncesi:}

$\mathrm{Bu}$ etkinliğin öncesinde rehber öğretmenler bir ders sunusu yaparak robotlarda kullanılan sonar, lazer, kızılötesi gibi bazı görsel sistemleri tanıtır. Bu sistemlerin benzerliklerini ve farklılıklarını anlatır. Işık sensörünün robota nasıl adapte edileceğini ve nasıl programlanacağını gösterir. Işık sensöründe karşılaşılan güçlükler ile ilgili sorunların nasıl çözülebileceğini anlatır.

Öğrenciler ise, bir önceki etkinlikte tasarlanan güvenlik robotunun belirli bir çizgiyi takip edebilmesi için gerekli programlama üzerinde çalışırlar. Bu çizgileri takip etmeyi sağlayacak olan 1 şı sensörü üzerinde çalışırlar ve sensörün robota eklenmesi 
için gerekli tasarımı yaparlar.

Robotun çizgiyi takip edebilmesi için programlanması: Robotu programlamaları için gereken komutlar öğrencilere projeksiyon cihazında sunulur. Sensörün çalışma prensibi ve NXT arasındaki uyum projeksiyon yardımı ile öğrencilere sunulur.

Yarışma ve Grup sunumları: 3 farklı çizginin izlenmesi içim 3 farklı yarışma yapılır. Çizgileri izleyerek hedefe en hızlı ulaşan grup yarışmayı kazanır. Bu aşamaya kadar olan süreçte karşılaşılan zorluklar not alınarak grupların hep birlikte bu sorunların nasıl çözülebileceğine ilişkin tartışma yapmakları istenir. Gerektiğinde eğitmenler gruplara yardım ederler.

Özet. Kapanışta, eğitmenler bu etkinlikte işlenen konuları özet bir şekilde tekrar ederler ve yapılan bu etkinliğin günlük ve endüstriyel alanlarda nasıl kullanıldıklarına ilişkin örnekler verirler. 


\section{E.7 Project Days}

Etkinlik Tarihi (Gün/Ay/Yıl): 02/02/2010 - 04/02/2010

Etkinliğin Adı: Projenin Verilmesi ve Proje Üzerinde Grupların Çalışması

Hedef Kitle: İlköğretim 6. sinıflar

Etkinliği yaptıracak kişi(ler):

\section{Takım koçları:}

Etkinliğin Amacı: Gruplara açık uçlu bir proje vererek öğrencilerin yaratıcılıklarını tetiklemek, problem çözme, analitik düşünme ve grup halinde çalışma becerilerini artırmaktır. Öğrenciler bu etkinlikte kendi robotlarını geliştirebildiklerini görecekler ve bu sayede de kendilerine olan özgüvenleri artacaktır.

Etkinliğin Konusu: Bu etkinlikte öğrencilerin gruplarıyla yapmaları gereken bir proje verilir. Proje gruplarından bir sınıfın zeminine rasgele bırakılmış kola kutularının toplayıp çöp tenekesine atan bir robot yapmaları istenir. Robotun belirli bir zaman içinde çok fazla sayıda kola kutularını çöp tenekesine atması gerekir $\mathrm{Bu}$ zaman içinde en fazla kola kutusu toplayan robotu geliştiren grup yarışmayı kazanır.

\section{Etkinliğin Süresi:}

$\begin{array}{ll}\text { 09:30 - 10:20 } & \text { Projenin verilmesi } \\ \text { 10:20 - 10:30 } & \text { Ara } \\ \text { 10:30 - 11:20 } & \text { Proje Üzerinde Grupların Çalışması } \\ \text { 11:20 - 11:30 } & \text { Ara } \\ \text { 11:30 - 12:20 } & \text { Proje Üzerinde Grupların Çalışması } \\ \text { 12:20 - 13:30 } & \text { Öğle yemeği } \\ \text { 13:30 - 14:20 } & \text { Proje Üzerinde Grupların Çalışması } \\ \text { 14:20-14:30 } & \text { Ara } \\ \text { 14:30 - 15:20 } & \text { Proje Üzerinde Grupların Çalışması } \\ \text { 15:20 - 15:30 } & \text { Ara } \\ \text { 15:30 - 16:20 } & \text { Proje Üzerinde Grupların Çalışması }\end{array}$

Kullanılacak Malzemeler:

Projeksiyon cihazı ve her bir grup için bir adet mezura, Lego Mindstorms seti, bilgisayar

Etkinliğin Nasıl Yapıldığı (Rehber sayısı, katılımcı sayısı, senaryolaştırılmış ayrintılı uygulama planı vs.):

Rehber sayısi: 3

Katılımcı sayısı: 24 (6 grup)

Projenin verilmesi. Yukarıda belirtilen proje öğrencilere duyurulur. Öğrencilerin soruları cevaplanır. 
Proje üzerinde grupların çalışması. Gruplar projeleri üzerinde çalışırlar.

Öğrencilerin problem üzerinde sistematik bir şekilde çalışmaları için grupların problemi analiz etmeleri ve kendi çözüm önerilerini tasarlamaları, geliştirmeleri ve değerlendirmeleri istenecektir. Öğrencilerin bu süreçleri takip etmelerini garantiye almak için süreç sonunda kısa raporlar (analiz raporu gibi) hazırlamaları istenir. Öğrencilerin başarısızlıktan dolayı ilgilerinin azalmaması için öğrenciler yüreklendirilip desteklenir ve gereken yardım ve yönlendirme sağlanır. Öğrencilerin grup içinde proje üzerinde yapıcı bir şekilde tartışmalarını sağlamak için öğretmenler gerektiğinde sorular (kola kutularını robot nasıl en doğru ve en hızlı bir şekilde algılar gibi) soracaktır. Öğrencilerin ilgi alanlarına ve becerilerine göre gerektiğinde projelerinde belirli görevler (yazılımcı, tasarımcı gibi) verilecektir. 


\section{E.8 The Last Day}

Etkinlik Tarihi (Gün/Ay/Yıl): 05/02/2010

Etkinliğin Adı: Proje Sunumları ve Hediyelerin Verilmesi

Hedef Kitle: İlköğretim 6. sinıflar

Etkinliği yaptıracak kişi(ler):

\section{Takım koçları:}

Etkinliğin Amacı: Kampın son gününde gerçekleştirilen yarışmada öğrencilerin centilmence rekabet etmelerini öğrenmelerini ve diğer grupların yaptığı projeleri görerek çok yönlü düşünmelerini sağlamaktır. Kampın sonunda sertifika verilerek öğrencilerin konuya ilgilerini artırmaktır. Öğrencilerin sunum yapmalarına imkan vererek sunum yapma ve bir toplum önünde konuşma becerilerini artırmaktır.

Etkinliğin Konusu: Bu etkinlikte gruplar yaptıkları robotları tüm sınıf huzurunda sergilerler. Gruplar daha sonra bu kampta öğrendiklerini, robot konularıyla derslerde işledikleri konuları nasıl ilişkilendirdiklerini, okulda görülen bu konuların gerçek hayatta ne işe yaradıklarını projektörden sunarlar. Tüm öğrencilere kampa katıldıklarını belgeleyen bir katılım belgesi verilir. Tüm öğrencilere kampa katılımlarından dolayı hediyeler (kitap, kalem, ayraç gibi) verilir.

\section{Etkinliğin Süresi:}

\begin{tabular}{|c|c|}
\hline $09: 30-10: 20$ & Proje sunumları \\
\hline $10: 20-10: 30$ & Ara \\
\hline $10: 30-11: 20$ & Proje sunumları \\
\hline $11: 20-11: 30$ & Ara \\
\hline $11: 30-12: 20$ & Proje sunumları \\
\hline $12: 20-13: 30$ & Öğle yemeği \\
\hline $13: 30-14: 20$ & Son testlerin uygulanmasi \\
\hline $14: 20-14: 30$ & Ara \\
\hline $14: 30-15: 20$ & Sertifikaların ve dereceye girenlere ödüllerinin verilmesi \\
\hline $15: 20-15: 30$ & Ara \\
\hline $15: 30-16: 20$ & Kapanış \\
\hline
\end{tabular}

\section{Kullanılacak Malzemeler:}

Projeksiyon cihazı

Her bir grup için Lego Mindstorms seti, bilgisayar

Etkinliğin Nasıl Yapıldığı (Rehber sayısı, katılımcı sayısı, senaryolaştırılmış ayrintılı uygulama planı vs.):

Rehber sayısi: 3

Katılımcı sayısı: 24 (6 grup)

Yarışma ve Proje sunumları. Gruplar yaptıkları robotu sergilerler. Robot belirli bir 
zaman içinde rasgele dağıtılmış kola kutularını hızla çöp kutusuna atması gerekmektedir. Çöpe atılmış her bir kola kutusu için gruplar puan alır. Robotların performansları gösterildikten sonra, gruplar problemi nasıl analiz ettiklerini, ne gibi bir çözüm önerisi tasarlayıp geliştirdiklerini tüm sınıfa projektörden sunarlar. Son olarak da kampta öğrendiklerini, robot konularıyla derslerde işledikleri konuları nasıl ilişkilendirdiklerini, okulda görülen bu konuların gerçek hayatta ne işe yaradıklarını anlatırlar.

Son testlerin uygulanması. Son testler uygulanır.

Sertifikaların ve hediyelerin verilmesi. Öğrencilere kampa katıldıklarını belgeleyen sertifikalar dağıtılır ve öğrencilere hediyeler verilir.

Kapanış. Kampın websitesinin adresi öğrencilere iletilir. Eğitmenlerle öğrencilerin iletişimlerini devam ettirmek için e-posta adresleri değişilir. Öğrencilerden kamp hakkında dönütler alınır. Son olarak da öğrencilerle vedalaşılır. 
APPENDIX F

ACTIVITY SHEET

Grup Adı:

\section{ÇALIŞMA KAĞIDI}

GÜNÜN YARIŞMASI: 3 farklı tekerlek için 2 metre ileri giden robot yapımı

Soru 1: Robotun aldığı yol ile tekerleğinin çevresi arasında ne gibi bir ilişki olabilir?

Soru 2: Robotunuz $50 \mathrm{~cm}$ yol alması için her bir tekerlek kaç tur atmalıdır? Küçük tekerlek: Orta tekerlek: , Büyük tekerlek:

Soru 3: Yol, tekerleğin çevresi ve turu arasındaki ilişkiyi gösteren denklem nedir?

Soru 4: 2 metre kaç santimetredir?

$2 m=$ $\mathrm{cm}$

Soru 5: Her bir tekerleğin çapı nedir?

Küçük tekerlek: , Orta tekerlek: Büyük tekerlek:

Soru 6: Tekerleklerin çevresini çapına bölünüz. Küçük: Çevre $=$ Orta: Cevre = - Orta: $\frac{\text { Çevre }}{\text { Çap }}$ Büyük: Çevre $=$ Çap Çap 
Soru 7: Tekerleğin çevresi ve çapı arasındaki ilişkiyi gösteren denklem nedir?

YARIŞMA: 3 farklı tekerlek için 2 metre ileri giden robot yapın.

Tekerlekler kaç tura programlanmalıdır?

Küçük tekerlek: Orta tekerlek: Büyük tekerlek: 
APPENDIX G

ACTIVITY SHEET

Grup Adı:

\section{ÇALIŞMA KAĞIDI}

GÜNÜN YARIŞMASI: 3 farklı tekerlek arası mesafe için 2 metre ileri gidip geri gelen bir robot yapımı

Soru 1: Robotu 180 derece döndürmek için tek bir tekerlek kaç tur atmalıdır?

Kisa mesafe: Orta mesafe: Uzun mesafe:

Soru 2: Dünkü aktivite kağıdını kullanarak her bir tekerleğin kat ettiği yolu bulunuz?

Kisa mesafe: Orta mesafe: Uzun mesafe:

Soru 3: Tekerlekler arasındaki mesafe nedir? Kisa mesafe: Orta mesafe: Uzun mesafe:

Soru 4: iki tekerlek arasındaki farklı mesafe ile tek bir tekerleğin kat ettiği yol arasındaki ilişkiyi gösteren denklem nedir?

YARIŞMA: 3 farklı tekerlek arası mesafe için 2 metre ileri gidip başlangıç noktasına geri dönen robot yapın. Tekerlekler ileri ve geri hareketi için kaç tura programlanmalıdır? Tekerlekler 180 derece dönmesi için kaç tura programlanmalıdır?

İleri ve Geri hareket için;

Kısa mesafe: Orta mesafe: Uzun mesafe: 
Tekerleklerin 180 derece dönmesi için; Kısa mesafe: Orta mesafe: Uzun mesafe: 
APPENDIX H

ACTIVITY SHEET

Grup Adı:

ÇALIŞMA KAĞIDI

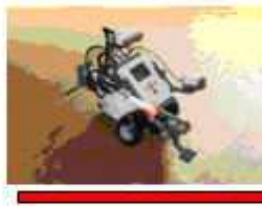

A

$\mathrm{C}$

B

A ile $C$ arasındaki uzaklık 2 metredir.

Robotunuz sabit hızla hareket etmektedir.

$A B$ arasındaki uzaklık $A C$ arasındaki uzaklığın 4 katıdır.

Bu bilgilerden yararlanarak, aşağıdaki soruların cevabını robotunuzu kullanarak bulunuz ve aşağıdaki tabloya yazınız

Soru 1: A noktasındaki robotun $C$ noktasına varması için geçen süre ne kadardır?

Soru 2: A noktasındaki robotun B noktasına varması için geçen süre ne kadardır?

Soru 3: A noktasından hareket eden robotun hızı kaç $\mathrm{m} / \mathrm{s} n$ ve kaç $\mathrm{km} /$ saat'tir. Robotunuz için 3 farklı deneme yapınız ve ortalama değerleri bulunuz ve aşağıdaki tabloya yazınız. 


\begin{tabular}{|c|c|c|c|c|c|c|c|}
\hline \multicolumn{3}{|c|}{ C Noktasına gelmesi için geçen süre (sn) } & \multicolumn{3}{|c|}{ B noktasına gelmesi için geçen süre (sn) } \\
\hline 1.Deneme & 2.Deneme & 3.Deneme & Ortalama & 1.Deneme & 2.Deneme & 3.Deneme & Ortalama \\
\hline & & & & & & & \\
\hline
\end{tabular}

Soru 4: Yukarıdaki tablodan elde ettiğiniz değerler için yol - zaman grafiği çiziniz

Soru 5: Yukarıdaki tablodan elde ettiğiniz ortalama değerleri aşağıdaki tabloya yazarak her iki robotun hızını hesaplayınız.

\begin{tabular}{|l|l|l|l|}
\hline Robot & A - B Uzaklığı (m) & Geçen Süre (sn) & $\begin{array}{l}\text { Hız= A-B Uzaklığ } \\
\text { / Geçen Süre }\end{array}$ \\
\hline $\begin{array}{l}\text { A-B Arasında } \\
\text { Hareket Eden } \\
\text { Robot }\end{array}$ & & & \\
\hline
\end{tabular}

$\mathrm{H}_{1 \mathrm{z}}=$ $m / s n$

\begin{tabular}{|l|l|l|l|}
\hline Robot & A - C Uzaklığı (m) & Geçen Süre (sn) & $\begin{array}{l}\text { Hız= A-C Uzaklığı } \\
\text { / Geçen Süre }\end{array}$ \\
\hline $\begin{array}{l}\text { A-C Arasında } \\
\text { Hareket Eden } \\
\text { Robot }\end{array}$ & & & \\
\hline
\end{tabular}

$\mathrm{H}_{1 \mathrm{z}}=$ $m / s n$

Soru 6: Bu etkinlik için robotunuzun motor gücünü değiştirerek hızını tekrar hesaplayınız.

\begin{tabular}{|l|l|l|l|l|l|l|l|}
\hline \multicolumn{3}{|c|}{$50 \%$ Güç } & \multicolumn{5}{c|}{$100 \%$ Güç } \\
\hline 1.Deneme & 2.Deneme & 3.Deneme & Ortalama & 1.Deneme & 2.Deneme & 3.Deneme & Ortalama \\
\hline & & & & & & & \\
\hline
\end{tabular}

Soru 7: Yukarıdaki tablodan elde ettiğiniz ortalama değerleri aşağıdaki tabloya yazarak her iki robotun hızını hesaplayınız.

\begin{tabular}{|l|l|l|l|}
\hline Robot & A - B Uzaklığı (m) & Geçen Süre (s) & $\begin{array}{l}\text { Hız= A-B Uzaklığ } \\
\text { / Geçen Süre }\end{array}$ \\
\hline $50 \%$ Güç & & & \\
\hline $100 \%$ Güç & & & \\
\hline
\end{tabular}


YARIŞMA: Gruplardan belirli hızda hareket eden robot yapmaları istenir. Kronometre ile ölçülen sabit bir süre (10 saniye gibi) boyunca robotun belirtilen hızda gitmesi amaçlanmaktadır. Yarışma 3 farklı hız için tekrarlanır. 
APPENDIX I

ACTIVITY SHEET

Grup Adı:

\section{ÇALIŞMA KAĞIDI}

GÜNÜN YARIŞMASI: Robotların karşısına bir engel çıkınca durup geri dönmesi ve farklı renklerdeki kitapları ayırt etmesi. Yarışma 3 defa farklı renklere sahip kitaplar için tekrarlanır.

Soru 1: Robota bağlı ultrasonic sensörün önüne değişik uzaklıkta kitap koyun. Ultrasonic sensörün okuduğu değer ile sizin ölçtüğünüz değerleri karşılaştırın.

\begin{tabular}{|l|l|}
\hline Kitap ile sensör arasındaki uzaklık & Ultrasonic sensörün ölçüm değeri \\
\hline & \\
\hline & \\
\hline & \\
\hline
\end{tabular}

Soru 2: Ultrasonic sensör uzaklığı sizce nasıl buluyor olabilir?

Soru 3: Ultrasonik sensörün yaydığı ses kaç saniyede engele çarpıp geri dönmektedir? (Sesin hızı = $340 \mathrm{~m} / \mathrm{sn}$ ) 
Soru 4: Uzaklık, sesin hızı ve zaman arasındaki ilişkiyi gösteren denklem nedir?

YARIŞMA: Robotların karşısına bir engel çıkınca durup geri dönmesi ve farklı renklerdeki kitapları ayırt etmesi. Yarışma 3 defa farklı renklere sahip kitaplar için tekrarlanır. 


\section{APPENDIX J}

ACTIVITY SHEET

\section{ÇALIŞMA KAĞIDI}

Soru 1: Robotun aldığı yol ile tekerleğinin çevresi arasında ne gibi bir ilişki olabilir?

Soru 2: Robotunuz $50 \mathrm{~cm}$ yol alması için her bir tekerlek kaç tur atmalıdır?

Küçük tekerlek: Orta tekerlek: Büyük tekerlek:

Soru 3: Yol, tekerleğin çevresi ve turu arasındaki ilişkiyi gösteren denklem nedir?

Soru 4: 1 metre kaç santimetredir?

$1 m=$ $\mathrm{cm}$ 
Soru 5: Her bir tekerleğin çapı nedir?

Küçük tekerlek: Orta tekerlek:

Büyük tekerlek:

Soru 6: Tekerleklerin çevresini çapına bölünüz.

Küçük: Cevre $=$

Orta: Cevre $=$

Büyük: Cevre $=$

Çap

Çap

Çap

Soru 7: Tekerleğin çevresi ve çapı arasındaki ilişkiyi gösteren denklem nedir?

Soru 8: 3 farklı tekerlek için 1 metre ileri giden robot yapın. Tekerlekler kaç tura programlanmalıdır?

Küçük tekerlek: Orta tekerlek: Büyük tekerlek:

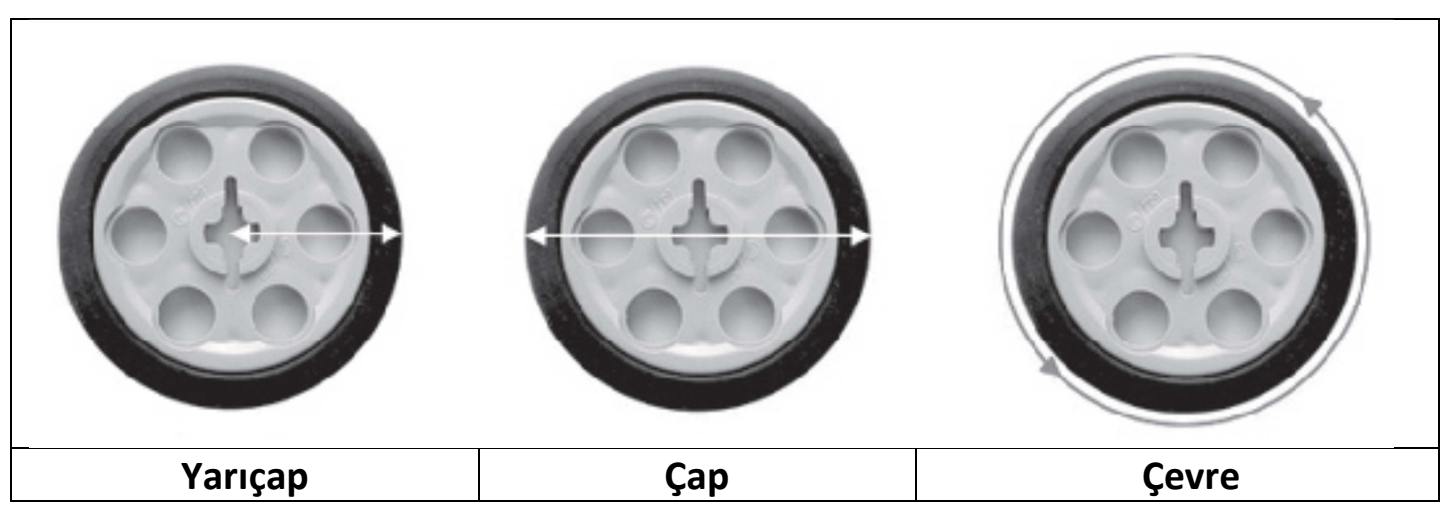




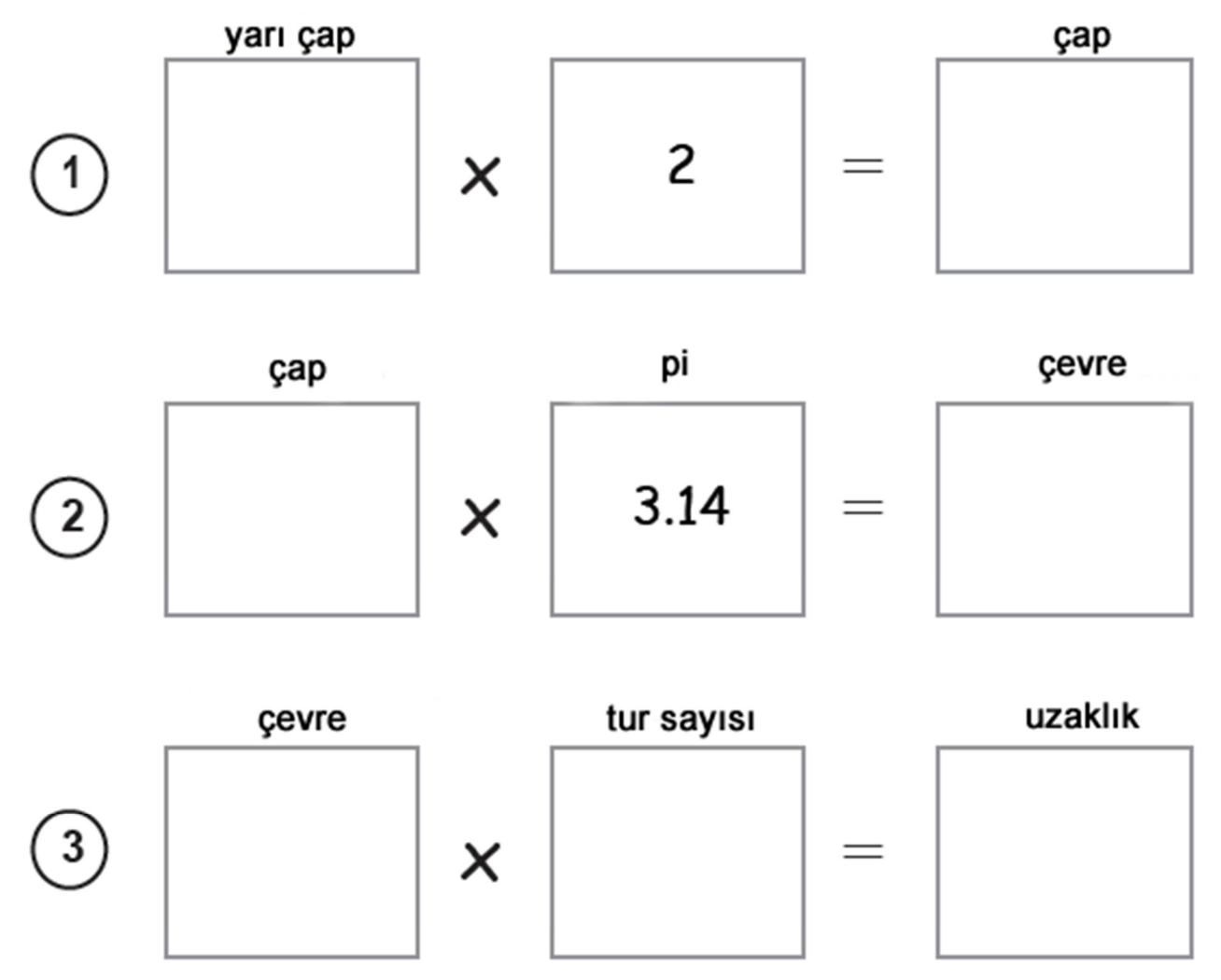


APPENDIX K

SIMPLE ROBOT DESIGN

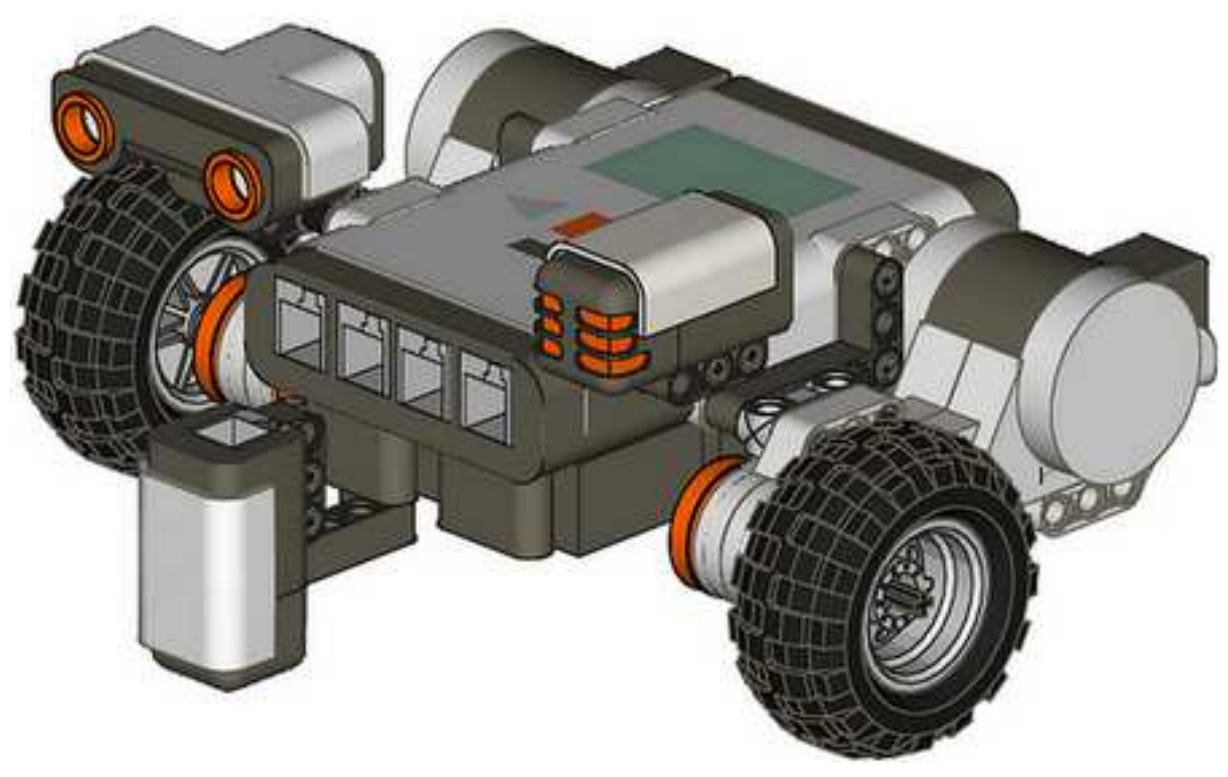

Figure E.8 Finished simple robot design 

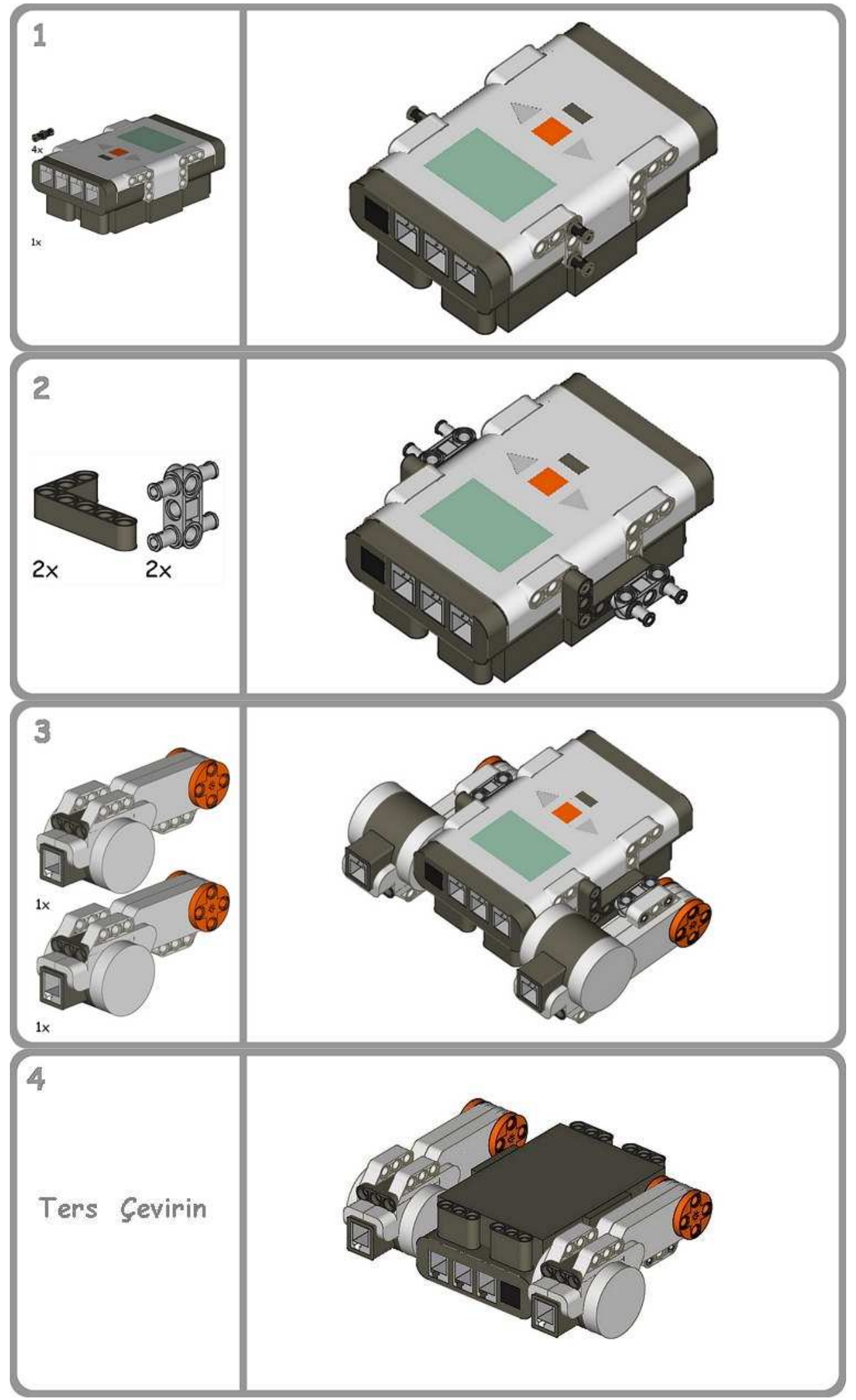

Figure E.9 Simple robot desing tutorial 


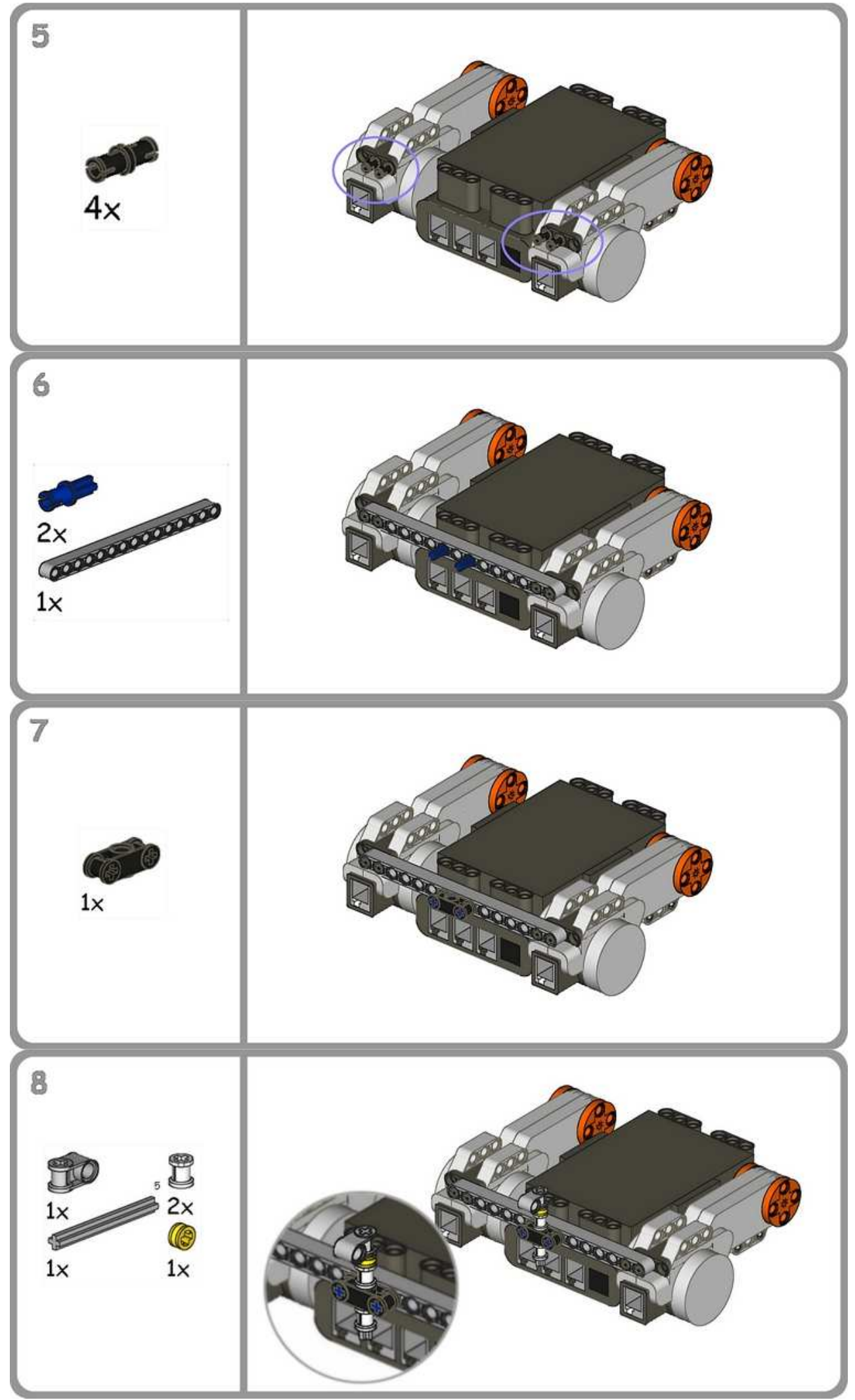

Figure E.10 Simple robot design tutorial 


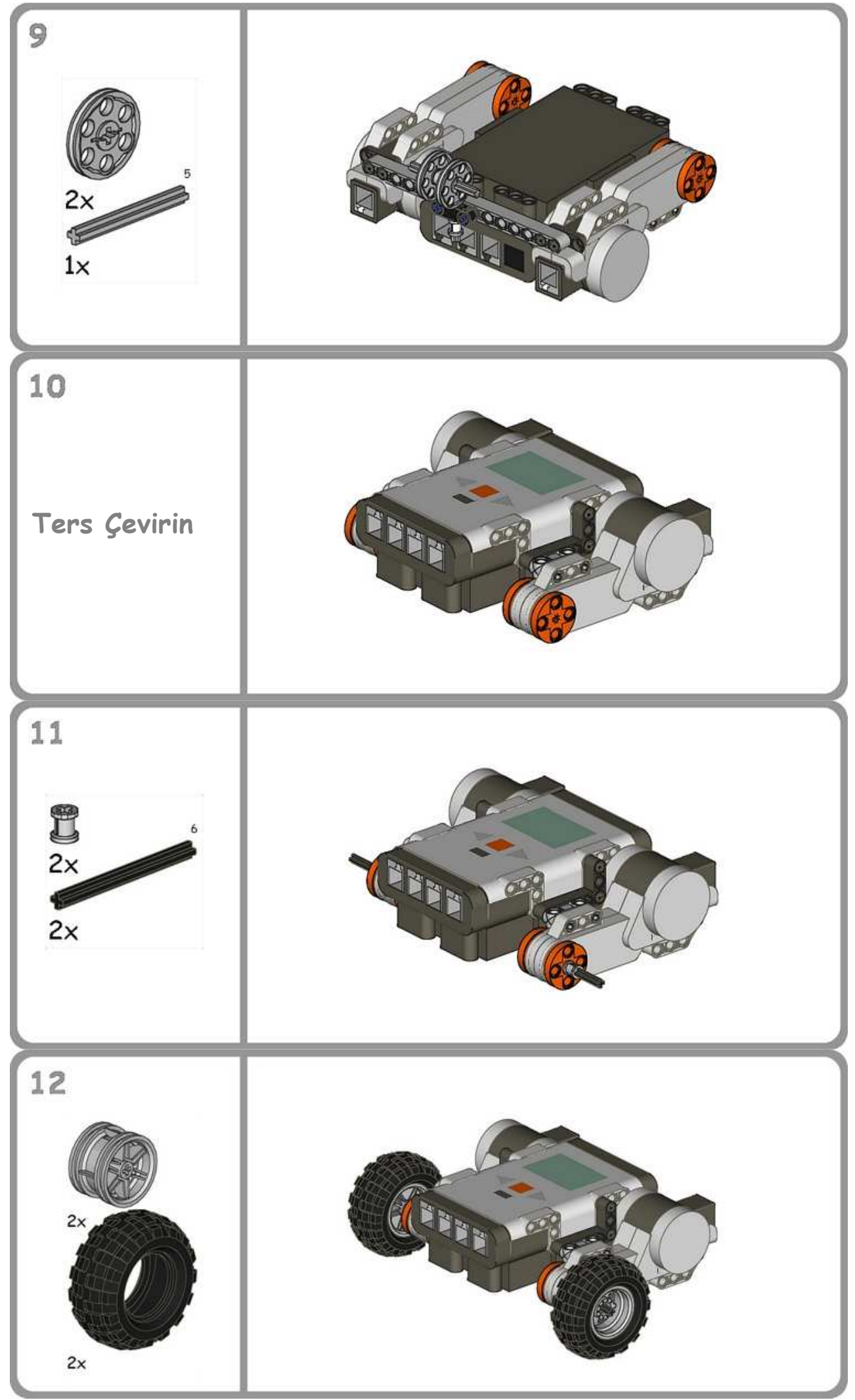

Figure E.11 Simple robot design tutorial 


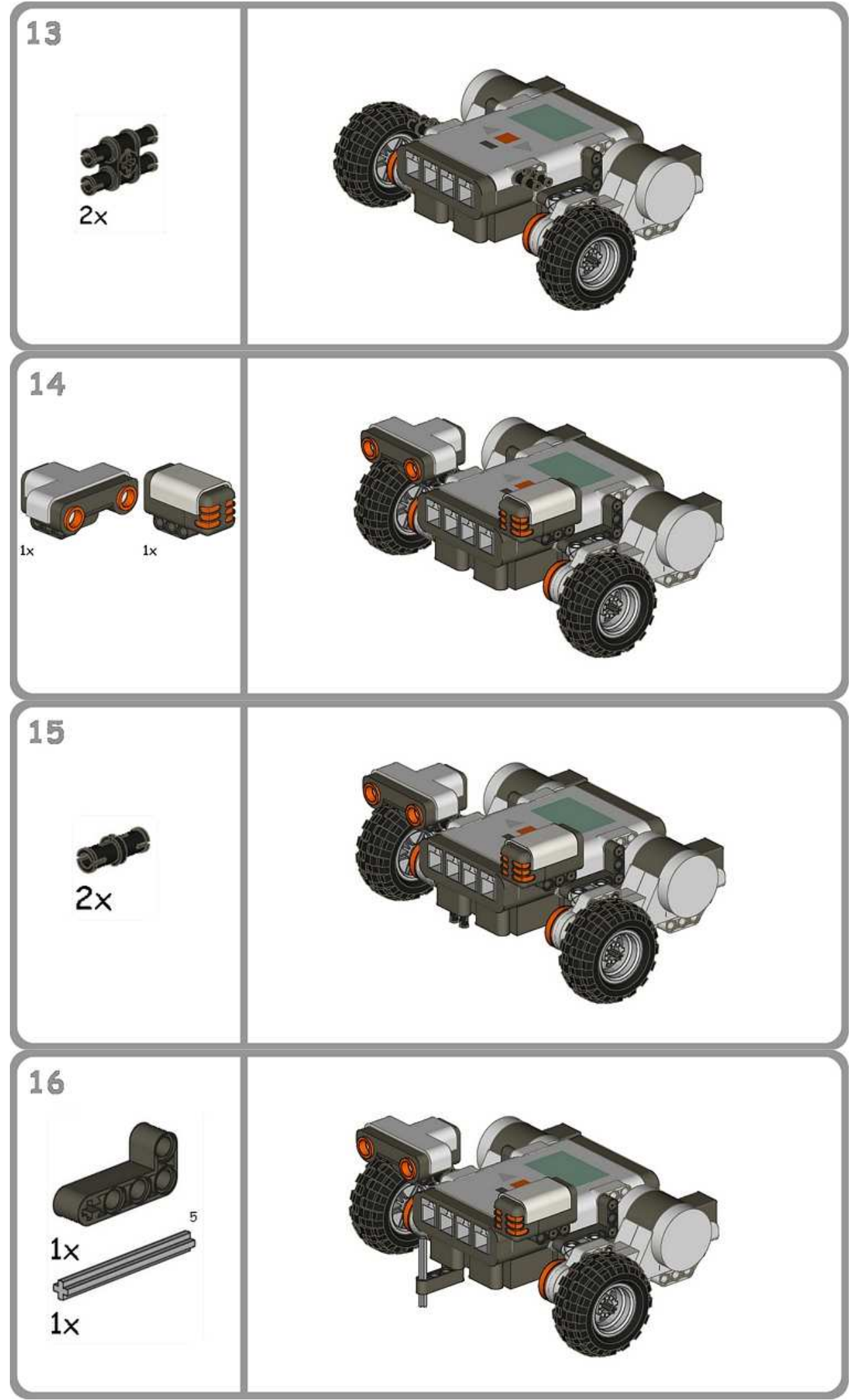

Figure E.12 Simple robot design tutorial 


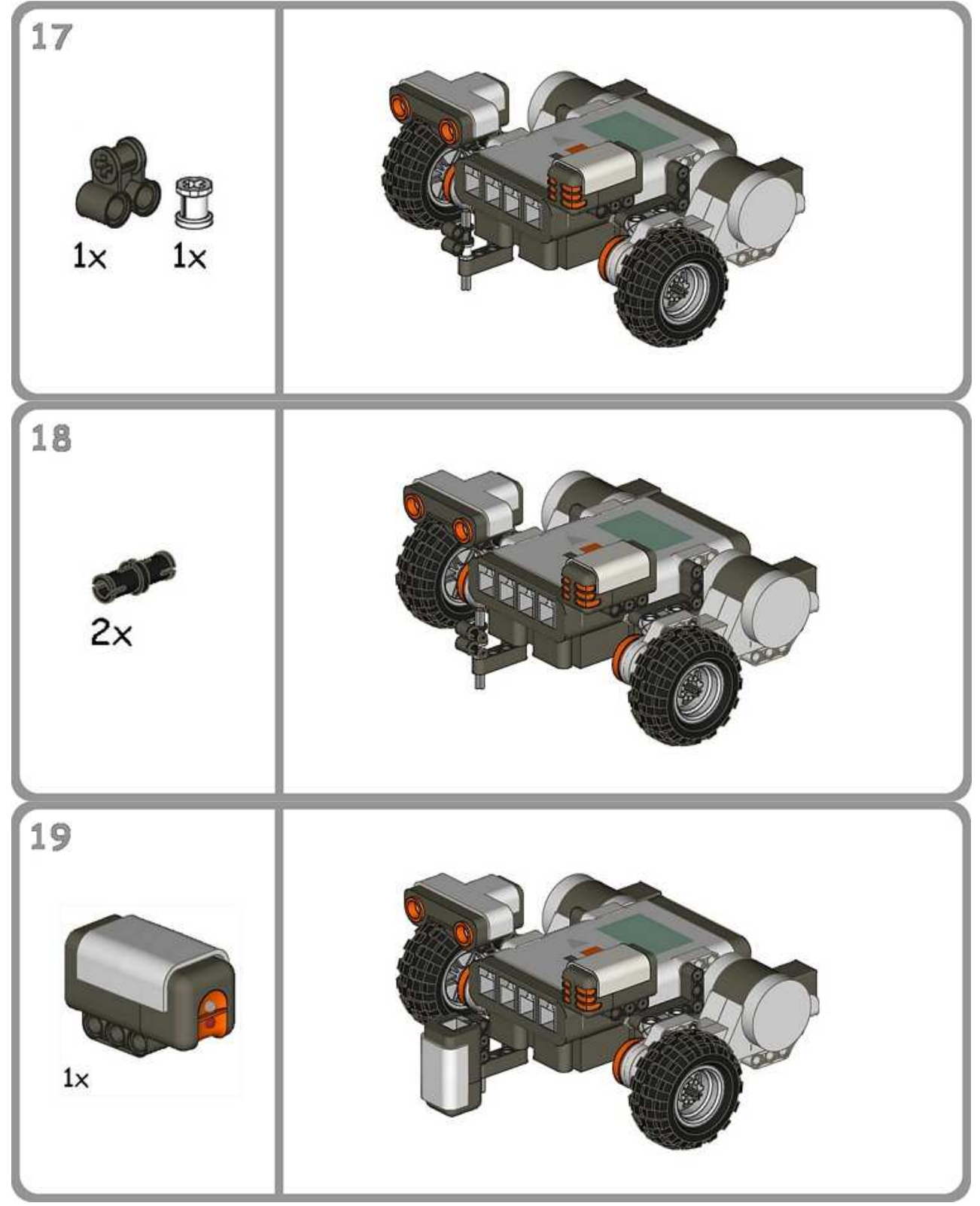

Figure E.13 Simple robot design tutorial

Kabloları da takınca

ROBOTUNUZ HAZIR

(:) :) (:) 


\section{APPENDIX L}

\section{CODING COMPARISON}

ลิ

Table L.1

Coding comparison

\begin{tabular}{|c|c|c|c|c|c|c|c|c|}
\hline Node & Source & Kappa & $\begin{array}{l}\text { Agreement } \\
(\%)\end{array}$ & $A$ and $B(\%)$ & $\begin{array}{l}\text { Not A and } \\
\text { Not B (\%) }\end{array}$ & $\begin{array}{l}\text { Dis- } \\
\text { agreement } \\
(\%)\end{array}$ & $\begin{array}{l}A \text { and } \\
\text { Not B } \\
(\%)\end{array}$ & $\begin{array}{l}B \text { and } \\
\text { Not A } \\
(\%)\end{array}$ \\
\hline Coaching & Kamp.I.14 & 0,323 & 86,82 & 3,79 & 83,03 & 13,18 & 13,14 & 0,03 \\
\hline Outcomes $\backslash$ Hint & Kamp.I.14 & 0 & 86,86 & 0 & 86,86 & 13,14 & 0 & 13,14 \\
\hline Coaching & Kamp.I.04 & 0,3045 & 90,23 & 2,43 & 87,8 & 9,77 & 9,77 & 0 \\
\hline Competition $\backslash$ Positive & Kamp.I.27 & 0,2982 & 90,57 & 2,27 & 88,3 & 9,43 & 0 & 9,43 \\
\hline Competition $\backslash$ Positive & Kamp.I.13 & 0 & 90,64 & 0 & 90,64 & 9,36 & 9,36 & 0 \\
\hline Competition $\backslash$ Desire to be the first & Kamp.I.27 & 0 & 90,81 & 0 & 90,81 & 9,19 & 9,19 & 0 \\
\hline
\end{tabular}


Table L.1 (continued)

\begin{tabular}{|c|c|c|c|c|c|c|c|c|}
\hline Group $\backslash$ Group problems $\backslash$ Little not important & Kamp.I.04 & 0,2864 & 92,12 & 1,75 & 90,37 & 7,88 & 7,88 & 0 \\
\hline Outcomes $\backslash$ Discovery learning & Kamp.I.13 & 0 & 92,6 & 0 & 92,6 & 7,4 & 7,4 & 0 \\
\hline Group $\backslash$ Group problems $\backslash$ Solutions $\backslash$ Bluff & Kamp.I.13 & 0 & 92,96 & 0 & 92,96 & 7,04 & 7,04 & 0 \\
\hline Outcomes $\backslash$ Learning with fun & Kamp.I.04 & 0 & 93,3 & 0 & 93,3 & 6,7 & 6,7 & 0 \\
\hline Coaching & Kamp.I.16 & 0,4108 & 93,33 & 2,56 & 90,76 & 6,67 & 6,67 & 0 \\
\hline Outcomes $\backslash$ Math $\backslash$ Math reinfoced & Kamp.I.14 & 0 & 93,88 & 0 & 93,88 & 6,12 & 6,12 & 0 \\
\hline Outcomes $\backslash$ Science $\backslash$ Science reinforced & Kamp.I.14 & 0 & 93,88 & 0 & 93,88 & 6,12 & 6,12 & 0 \\
\hline Group $\backslash$ Group size $\backslash 4$ is fine & Kamp.I.04 & 0,3766 & 93,95 & 1,99 & 91,97 & 6,05 & 6,02 & 0,03 \\
\hline Competition $\backslash$ Negative & Kamp.I.14 & 0 & 93,96 & 0 & 93,96 & 6,04 & 6,04 & 0 \\
\hline Group $\backslash$ Group problems $\backslash$ Solutions $\backslash$ Task sharing & Kamp.I.27 & 0 & 94,32 & 0 & 94,32 & 5,68 & 0 & 5,68 \\
\hline Activity Sheets $\backslash$ Learned better & Kamp.I.27 & 0 & 94,39 & 0 & 94,39 & 5,61 & 5,61 & 0 \\
\hline Activity Sheets $\backslash$ Review & Kamp.I.27 & 0 & 94,39 & 0 & 94,39 & 5,61 & 5,61 & 0 \\
\hline Usage in formal education $\backslash$ Technology design course & Kamp.I.16 & 0,4915 & 94,49 & 2,91 & 91,58 & 5,51 & 5,51 & 0 \\
\hline Group $\backslash$ Group problems & Kamp.I.27 & 0 & 94,96 & 0 & 94,96 & 5,04 & 5,04 & 0 \\
\hline Technical problems $\backslash$ Robot loses its mind & Kamp.I.27 & 0 & 95,09 & 0 & 95,09 & 4,91 & 4,91 & 0 \\
\hline Group $\backslash$ Gender $\backslash I$ prefer all girls & Kamp.I.13 & 0 & 95,49 & 0 & 95,49 & 4,51 & 4,51 & 0 \\
\hline Group $\backslash$ Gender $\backslash$ I prefer all boys $\backslash I$ blush & Kamp.I.04 & 0,3908 & 95,61 & 1,5 & 94,11 & 4,39 & 4,39 & 0 \\
\hline Activity Sheets $\backslash$ Learned new things & Kamp.I.13 & 0,5424 & 95,68 & 2,8 & 92,88 & 4,32 & 2,55 & 1,77 \\
\hline Competition $\backslash$ Tournament event & Kamp.I.14 & 0 & 96,05 & 0 & 96,05 & 3,95 & 0 & 3,95 \\
\hline Group $\backslash$ Group problems $\backslash$ Not interested & Kamp.I.16 & 0,6716 & 96,34 & 4,06 & 92,28 & 3,66 & 3,66 & 0 \\
\hline Outcomes $\backslash$ Robotic $\backslash$ Robot Mechanic & Kamp.I.13 & 0 & 96,34 & 0 & 96,34 & 3,66 & 0 & 3,66 \\
\hline Outcomes $\backslash$ Discovery learning & Kamp.I.16 & 0 & 96,35 & 0 & 96,35 & 3,65 & 0 & 3,65 \\
\hline Group $\backslash$ Gender $\backslash$ Mixed is better & Kamp.I.27 & 0 & 96,37 & 0 & 96,37 & 3,63 & 3,63 & 0 \\
\hline Outcomes $\backslash$ Robotic $\backslash$ Sensors - GSD & Kamp.I.13 & 0 & 96,46 & 0 & 96,46 & 3,54 & 3,54 & 0 \\
\hline
\end{tabular}


Table L.1 (continued)

\begin{tabular}{|c|c|c|c|c|c|c|c|c|}
\hline Group $\backslash$ Group size $\backslash 3$ is Fine & Kamp.I.13 & 0 & 96,58 & 0 & 96,58 & 3,42 & 3,42 & 0 \\
\hline Group $\backslash$ Group problems $\backslash$ Group member & Kamp.I.13 & 0 & 96,63 & 0 & 96,63 & 3,37 & 3,37 & 0 \\
\hline Group $\backslash$ Gender $\backslash$ Mixed is better & Kamp.I.16 & 0,5919 & 96,67 & 2,56 & 94,11 & 3,33 & 3,33 & 0 \\
\hline Activity Sheets $\backslash$ Learned better & Kamp.I.04 & 0 & 96,7 & 0 & 96,7 & 3,3 & 3,3 & 0 \\
\hline Technical problems $\backslash$ Battery & Kamp.I.13 & 0,4324 & 96,77 & 1,29 & 95,47 & 3,23 & 3,23 & 0 \\
\hline Group $\backslash$ Gender $\backslash$ I prefer all girls & Kamp.I.27 & 0 & 96,84 & 0 & 96,84 & 3,16 & 0 & 3,16 \\
\hline Technical problems $\backslash$ Sensors & Kamp.I.27 & 0 & 96,87 & 0 & 96,87 & 3,13 & 0 & 3,13 \\
\hline Outcomes $\backslash$ Learning with fun & Kamp.I.13 & 0,7173 & 96,92 & 4,22 & 92,7 & 3,08 & 3,08 & 0 \\
\hline Outcomes $\backslash$ Learning from manual & Kamp.I.27 & 0 & 96,96 & 0 & 96,96 & 3,04 & 3,04 & 0 \\
\hline Group $\backslash$ Group problems $\backslash$ Want to do more & Kamp.I.13 & 0 & 96,99 & 0 & 96,99 & 3,01 & 0 & 3,01 \\
\hline Outcomes $\backslash$ Robotic $\backslash$ Programming & Kamp.I.14 & 0,7135 & 97,05 & 3,95 & 93,1 & 2,95 & 0 & 2,95 \\
\hline Activity Sheets $\backslash$ Like quiz & Kamp.I.16 & 0 & 97,1 & 0 & 97,1 & 2,9 & 0 & 2,9 \\
\hline Activity Sheets $\backslash$ Math related & Kamp.I.16 & 0 & 97,1 & 0 & 97,1 & 2,9 & 2,9 & 0 \\
\hline Technical problems $\backslash$ Robots' memory shortage & Kamp.I.16 & 0 & 97,32 & 0 & 97,32 & 2,68 & 0 & 2,68 \\
\hline Difficulties $\backslash$ Combining & Kamp.I.14 & 0 & 97,34 & 0 & 97,34 & 2,66 & 0 & 2,66 \\
\hline Difficulties $\backslash$ Programming & Kamp.I.14 & 0 & 97,34 & 0 & 97,34 & 2,66 & 2,66 & 0 \\
\hline Competition $\backslash$ Positive & Kamp.I.04 & 0 & 97,38 & 0 & 97,38 & 2,62 & 2,62 & 0 \\
\hline Coaching & Kamp.I.13 & 0 & 97,71 & 0 & 97,71 & 2,29 & 0 & 2,29 \\
\hline Group $\backslash$ Group problems $\backslash$ Solutions & Kamp.I.16 & 0 & 97,77 & 0 & 97,77 & 2,23 & 2,23 & 0 \\
\hline Demographics $\backslash$ Lego experience $\backslash$ No & Kamp.I.04 & 0,0816 & 97,84 & 0,1 & 97,75 & 2,16 & 2,16 & 0 \\
\hline Difficulties $\backslash$ Programming & Kamp.I.27 & 0,3776 & 97,9 & 0,66 & 97,24 & 2,1 & 2,1 & 0 \\
\hline Activity Sheets $\backslash$ Learned better & Kamp.I.16 & 0 & 97,91 & 0 & 97,91 & 2,09 & 0 & 2,09 \\
\hline Activity Sheets $\backslash$ Review & Kamp.I.16 & 0 & 97,91 & 0 & 97,91 & 2,09 & 2,09 & 0 \\
\hline Group $\backslash$ Gender $\backslash$ I prefer all boys & Kamp.I.04 & 0 & 97,93 & 0 & 97,93 & 2,07 & 0 & 2,07 \\
\hline
\end{tabular}


Table L.1 (continued)

\begin{tabular}{|c|c|c|c|c|c|c|c|c|}
\hline Activity Sheets $\backslash$ Math related & Kamp.I.13 & 0 & 98,26 & 0 & 98,26 & 1,74 & 1,74 & 0 \\
\hline Usage in formal education $\backslash$ Technology design course & Kamp.I.13 & 0,8551 & 98,28 & 5,47 & 92,81 & 1,72 & 1,72 & 0 \\
\hline Demographics $\backslash$ Lego experience $\backslash$ Yes & Kamp.I.14 & 0,5293 & 98,34 & 0,96 & 97,38 & 1,66 & 1,66 & 0 \\
\hline Activity Sheets $\backslash$ Note - remember & Kamp.I.04 & 0 & 98,38 & 0 & 98,38 & 1,62 & 0 & 1,62 \\
\hline Outcomes $\backslash$ Robotic $\backslash$ Robot Mechanic & Kamp.I.04 & 0,512 & 98,57 & 0,77 & 97,8 & 1,43 & 0,36 & 1,06 \\
\hline Group $\backslash$ Group problems $\backslash$ Solutions $\backslash$ Task sharing & Kamp.I.04 & 0 & 98,64 & 0 & 98,64 & 1,36 & 0 & 1,36 \\
\hline Group $\backslash$ Group size $\backslash 3$ is Fine & Kamp.I.14 & 0,7301 & 98,66 & 1,87 & 96,79 & 1,34 & 1,34 & 0 \\
\hline Demographics $\backslash$ Lego experience $\backslash$ Yes & Kamp.I.16 & 0,4517 & 98,67 & 0,56 & 98,11 & 1,33 & 1,33 & 0 \\
\hline Coaching & Kamp.I.27 & 0,9234 & 98,69 & 8,79 & 89,9 & 1,31 & 0,66 & 0,66 \\
\hline Difficulties $\backslash$ Combining & Kamp.I.27 & 0,789 & 98,69 & 2,55 & 96,14 & 1,31 & 0,64 & 0,67 \\
\hline Outcomes $\backslash$ Math $\backslash$ Circumference - pi & Kamp.I.16 & 0,4429 & 98,72 & 0,52 & 98,2 & 1,28 & 1,28 & 0 \\
\hline Outcomes $\backslash$ Robotic $\backslash$ Programming & Kamp.I.04 & 0,616 & 98,73 & 1,05 & 97,68 & 1,27 & 0,49 & 0,78 \\
\hline Group $\backslash$ Group size $\backslash 3$ is Fine & Kamp.I.27 & 0,8175 & 98,79 & 2,82 & 95,97 & 1,21 & 0 & 1,21 \\
\hline Difficulties $\backslash$ Programming & Kamp.I.04 & 0 & 98,8 & 0 & 98,8 & 1,2 & 0 & 1,2 \\
\hline Demographics $\backslash \#$ of bros \& sis $\backslash 3$ & Kamp.I.04 & 0,0471 & 98,88 & 0,03 & 98,85 & 1,12 & 1,12 & 0 \\
\hline Group $\backslash$ Group size $\backslash 3$ is Fine & Kamp.I.04 & 0 & 98,88 & 0 & 98,88 & 1,12 & 0 & 1,12 \\
\hline Competition $\backslash$ Negative & Kamp.I.04 & 0,8599 & 98,91 & 3,51 & 95,4 & 1,09 & 1,09 & 0 \\
\hline Outcomes $\backslash$ Career & Kamp.I.13 & 0,7606 & 98,92 & 1,77 & 97,14 & 1,08 & 0 & 1,08 \\
\hline Demographics $\backslash$ Lego experience $\backslash$ Yes & Kamp.I.13 & 0,7935 & 98,93 & 2,12 & 96,82 & 1,07 & 1,07 & 0 \\
\hline Usage in formal education $\backslash$ Math course & Kamp.I.27 & 0,8157 & 99,01 & 2,27 & 96,74 & 0,99 & 0,99 & 0 \\
\hline Outcomes $\backslash$ Social skills $\backslash$ Losing Winning Case & Kamp.I.16 & 0 & 99,2 & 0 & 99,2 & 0,8 & 0 & 0,8 \\
\hline Technical problems $\backslash$ Battery charger & Kamp.I.14 & 0,798 & 99,23 & 1,56 & 97,67 & 0,77 & 0,77 & 0 \\
\hline Difficulties & Kamp.I.04 & 0 & 99,29 & 0 & 99,29 & 0,71 & 0,71 & 0 \\
\hline Demographics $\backslash$ Father's job $\backslash$ Tradesman & Kamp.I.14 & 0,6048 & 99,31 & 0,53 & 98,78 & 0,69 & 0,65 & 0,03 \\
\hline
\end{tabular}


Table L.1 (continued)

\begin{tabular}{|c|c|c|c|c|c|c|c|c|}
\hline Demographics $\backslash$ Father's job $\backslash$ Worker & Kamp.I.13 & 0,7134 & 99,35 & 0,83 & 98,52 & 0,65 & 0,65 & 0 \\
\hline Demographics $\backslash$ Mother's job $\backslash$ Housewife & Kamp.I.27 & 0,4827 & 99,43 & 0,27 & 99,16 & 0,57 & 0,57 & 0 \\
\hline Demographics $\backslash$ Mother's job $\backslash$ Working & Kamp.I.14 & 0,6349 & 99,43 & 0,5 & 98,94 & 0,57 & 0 & 0,57 \\
\hline Demographics $\backslash \#$ of bros \& sis $\backslash 3$ & Kamp.I.16 & 0,5804 & 99,46 & 0,38 & 99,08 & 0,54 & 0,54 & 0 \\
\hline Outcomes $\backslash$ Career & Kamp.I.04 & 0 & 99,5 & 0 & 99,5 & 0,5 & 0,5 & 0 \\
\hline Outcomes $\backslash$ Friendship & Kamp.I.27 & 0,8924 & 99,58 & 1,78 & 97,8 & 0,42 & 0,42 & 0 \\
\hline Activity Sheets $\backslash$ Learned new things & Kamp.I.14 & 0,901 & 99,61 & 1,84 & 97,77 & 0,39 & 0,39 & 0 \\
\hline Demographics $\backslash$ Mother's job $\backslash$ Working & Kamp.I.13 & 0,7325 & 99,64 & 0,5 & 99,14 & 0,36 & 0,36 & 0 \\
\hline Demographics $\backslash$ Father's job $\backslash$ Tradesman & Kamp.I.04 & 0,6782 & 99,76 & 0,25 & 99,51 & 0,24 & 0,24 & 0 \\
\hline Demographics $\backslash$ Mother's job $\backslash$ Working & Kamp.I.04 & 0,9686 & 99,97 & 0,43 & 99,54 & 0,03 & 0,03 & 0 \\
\hline Competition $\backslash$ Positive & Kamp.I.14 & 0,9969 & 99,98 & 2,88 & 97,1 & 0,02 & 0,02 & 0 \\
\hline Demographics $\backslash$ Father's job $\backslash$ Officer & Kamp.I.16 & 0,9713 & 99,98 & 0,35 & 99,63 & 0,02 & 0 & 0,02 \\
\hline Outcomes $\backslash$ Robotic $\backslash$ Programming & Kamp.I.13 & 0,9876 & 99,98 & 0,69 & 99,29 & 0,02 & 0 & 0,02 \\
\hline Demographics $\backslash$ Mother's job $\backslash$ Housewife & Kamp.I.16 & 0,9892 & 99,99 & 0,47 & 99,52 & 0,01 & 0 & 0,01 \\
\hline Activity Sheets & Kamp.I.04 & 1 & 100 & 0 & 100 & 0 & 0 & 0 \\
\hline Activity Sheets & Kamp.I.13 & 1 & 100 & 0 & 100 & 0 & 0 & 0 \\
\hline Activity Sheets & Kamp.I.14 & 1 & 100 & 0 & 100 & 0 & 0 & 0 \\
\hline
\end{tabular}

Note: Table is sorted by agreement coloumn, the rest 465 row of the table is omited bacause of $100 \%$ agreement. 
APPENDIX M

\section{SAMPLE ROBOTICS CAMP CURRICULUM}

A sample robotic curriculum is presented in this section; the curriculum was designed based on the results of the study and experiences of the researcher. The camp goes from 9:30 to 15:20, two weeks Monday to Friday. There should be six groups and each group should consist of three $6^{\text {th }}$ grade children.

Different from the previous camps, this camp will be supported with a web page. Firstly the web page should contain tutorials about how to combine and program Lego Mindstorms NXTs. Secondly, each group will log in to web site and they get their missions from that web page via multimedia. That is they will watch a short movies explaining or giving clues about the missions. When they achieve a mission, they will enter the result of the measurement or a code they get from the work area when they achieve the specific objective, into the web page then they going to pass next mission. Like video games but they achieve missions at real world with the robots.

The whole camp based on a story. The moon station (See Figure M.2) which consist of three separate buildings which are base, power control unit and rector have hit by meteor storms. Because of radiation leak, only the base station is safe, the conditions of the other two bases are unknown. Therefore, robotic teams will constitute and be trained about new robotic sets Lego Mindstorms NXT. After their training, the teams will send to moon base station and their objective is programming and designing their robots, to reach other two stations and fix the problems. 
For each groups, LEGO MINDSTORMS Education NXT Base Set, LEGO MINDSTORMS Education Resource Set and a computer will be required. For each group work area should be prepared (Figure M.2). Moreover, for the one activity magnetic sensors will be required.

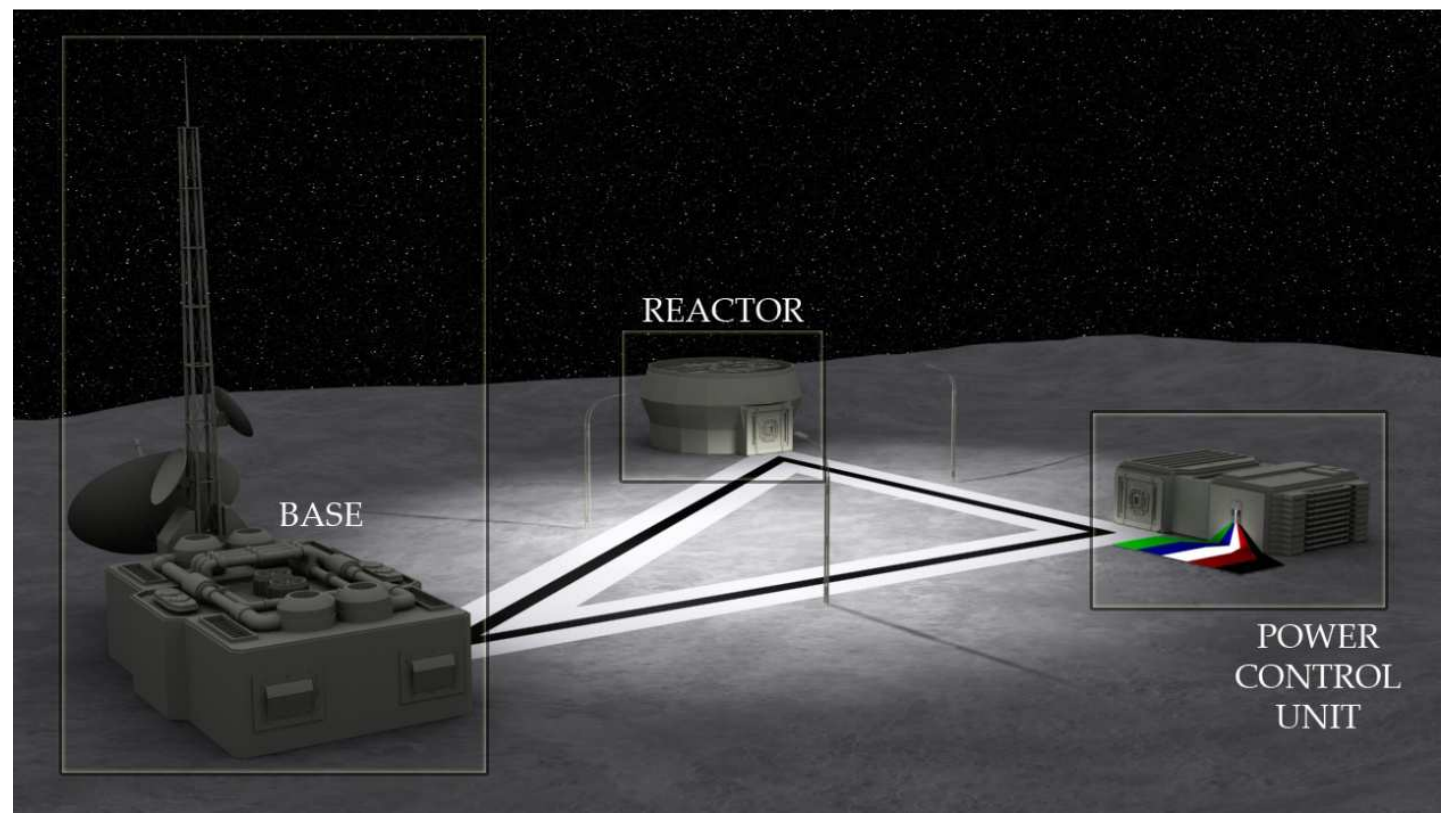

Figure M.1 Moon Station

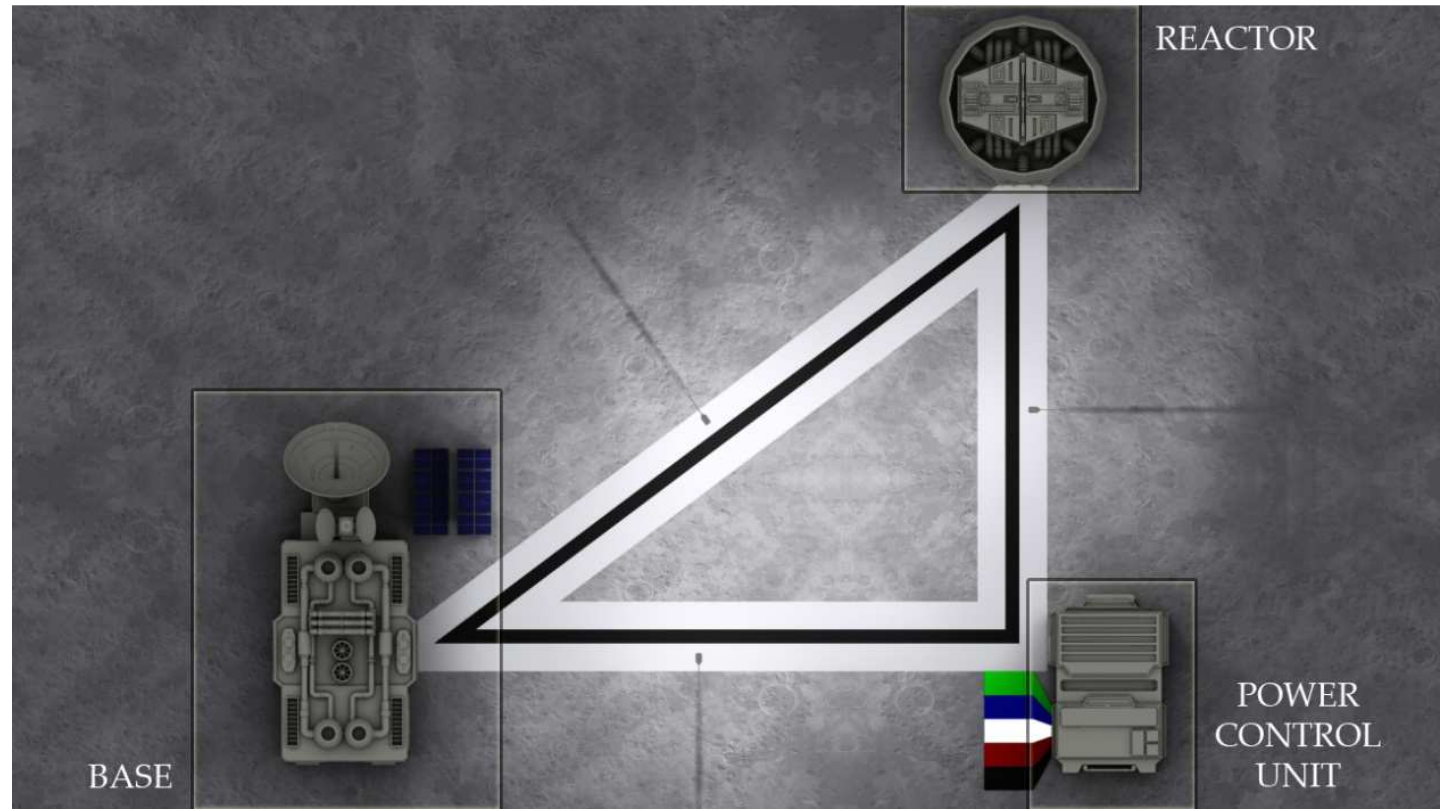

Figure M.2 Work Area 
Like the second camp, the first three days of the camp will be allocated to robotics and programming. Different from the second camp, "NXT Data Logging" will be emphasized because the children will use robots as data collector in missions. Later, the children will interpret that data on the computer.

\section{M.1 The First Day}

\begin{tabular}{|c|c|}
\hline $09: 30-10: 20$ & Introduction \\
\hline \multirow[t]{3}{*}{$10: 30-11: 20$} & Discussion on robots \\
\hline & Short movies about Lego Mindstorms NXT \\
\hline & Drawing my imaginary robot \\
\hline \multirow[t]{2}{*}{$11: 30-12: 20$} & Discussion on programming \\
\hline & Programming drama - algorithm \\
\hline $12: 30-13: 20$ & Lunch break \\
\hline \multirow[t]{2}{*}{$13: 30-14: 20$} & Introduction to Lego Mindstorms NXT sets \\
\hline & Components of Lego Mindstorms NXT sets \\
\hline \multirow[t]{3}{*}{$14: 30-15: 20$} & Creating simple robots (Appendix K) \\
\hline & Programming on NXT screen \\
\hline & Packing up \\
\hline
\end{tabular}

The focus of the first day of the camp will be introduction. The story of the camp will be told. They will learn that they will take a three days robotics education and their mission is programming their robots to solve the problems of Moon Station. The children will introduce programming and Lego Mindstroms NXT sets and these two concepts are new for them. Therefore before they start to programming and building their own robots the children should feel confidence about the camp. With the discussion and activities the children should understand clearly that what robots are and their characteristics. After that, the programming concept should be clearly stated with discussion and drama activity.

At the afternoon section of the first day, the children will introduce Lego Mindstorms NXT robotic sets. They should have chance to explore the sets and guess its 
components and their functions. They will combine a simple robot and make simple program on the NXT screen without using computer.

\section{M.2 The Second Day}

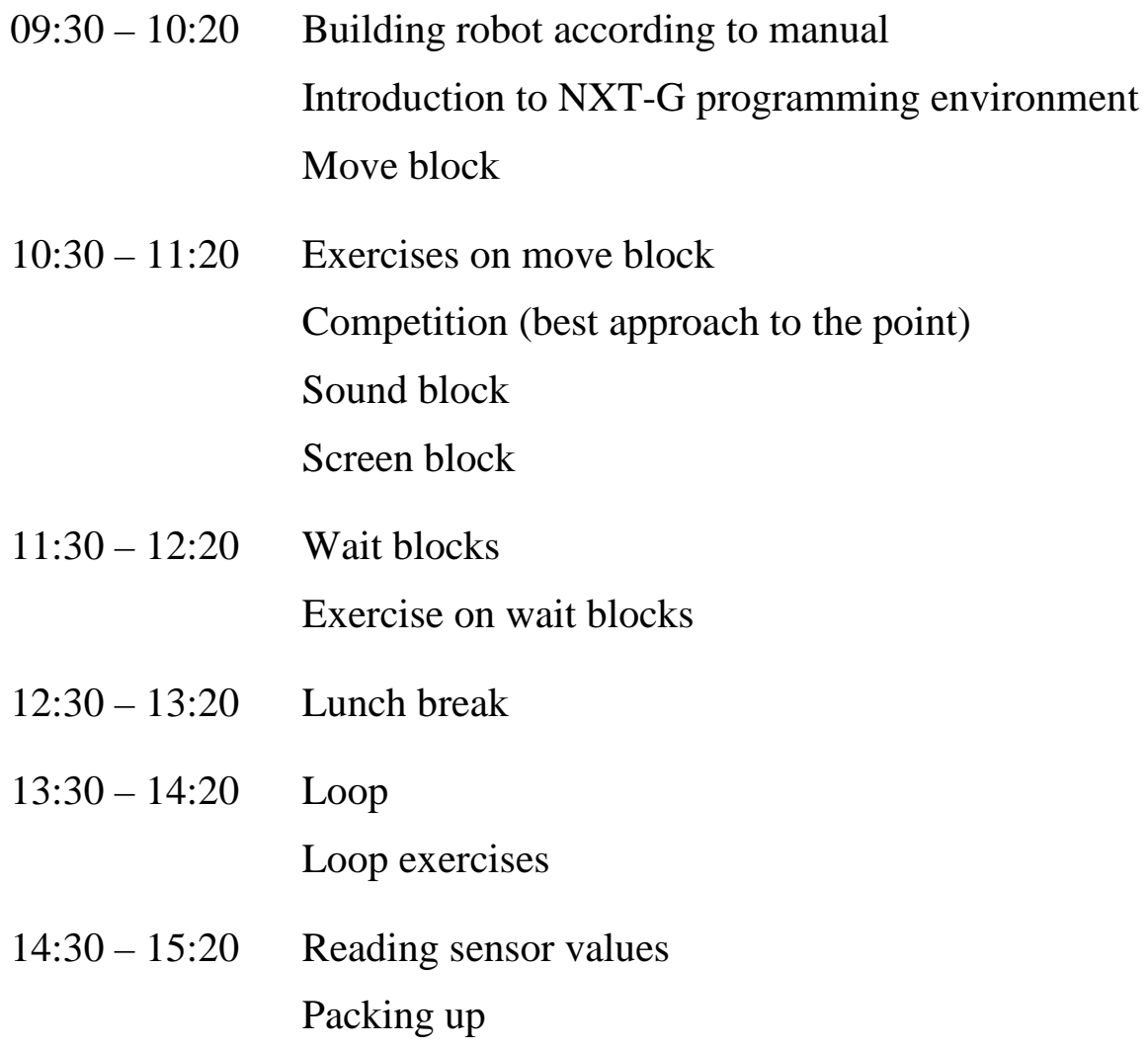

On the second day of the camp, the children will work on programming. Therefore, NXT-G programming environments will be introduced to the children and drag and drop programming approach with programming blocks will be explained by using projection.

The children should have chance to proactive what they have learnt with some exercises. Moreover, some competition could be arranged to increase motivation and prevent them getting bored. For example, after they have learnt move block, they should asked to make a program their robots will move exactly 2 meters. A point 2 meters away from the start line could be defined and the closest robots to the point will be the winner and so on. 


\section{M.3 The Third Day}

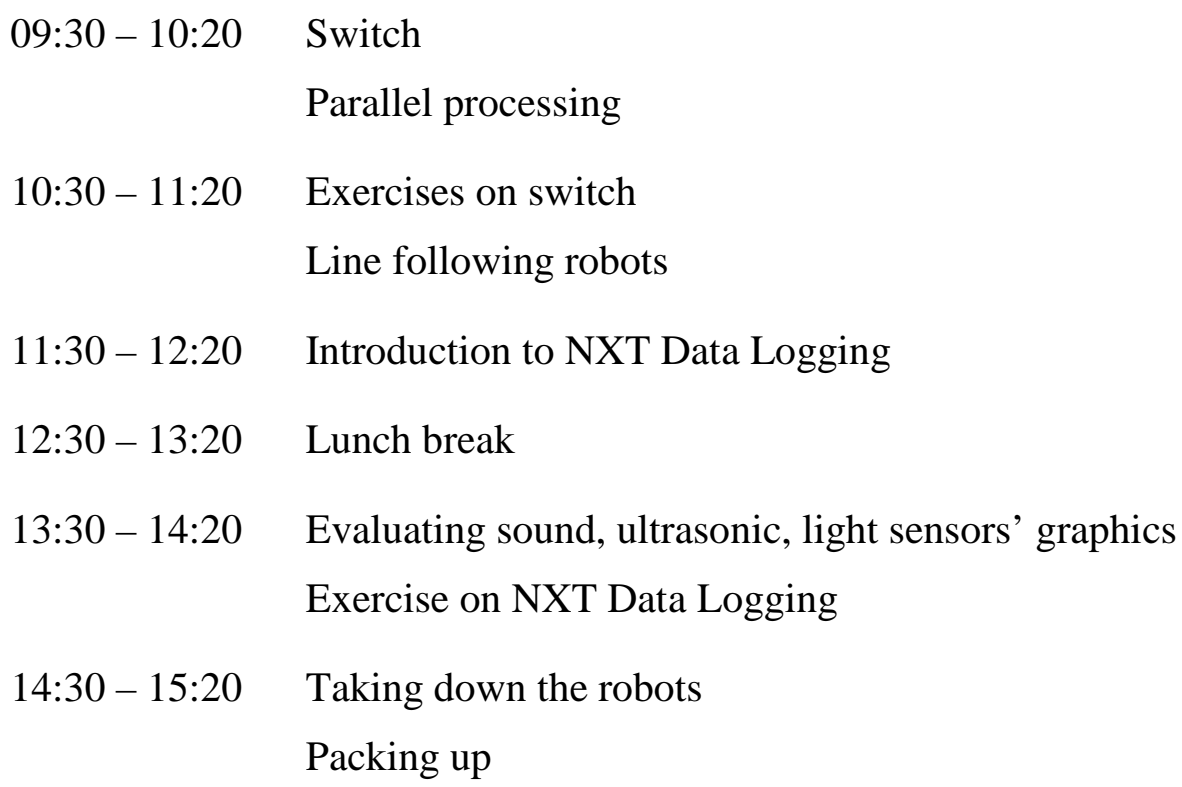

The last day of the programming section is reserved for more advanced programming blocks and NXT Data Logging software. The children will learn how they will program their robots to collect data from sensors and evaluation of these data on the computer. Similar to the previous day the children should be challenged with some exercises. At the end of the day each groups should take down their robots because they will start moon station missions on next day.

\section{M.4 The Fourth, Fifth and Sixth Days}

Until the seventh day of the camp, each group will work Moon Station missions on a printed work area (Figure M.2). Moon Station missions also could be done with learning stations approach like the second camp. If the learning station approach will be used, the missions must be arranged according to the number of the groups. Moreover, to prevent groups waiting each other, each mission must be finished at the same time.

Until the fourth day, the groups and their passwords should be defined for the web page. The children will log in to the web page to get their missions. Like the video games, when they logged on they could continue where they had left. 
After the each mission, an instructor should make discussion on what they have learnt and which science knowledge they have used. If it is required, the instructor should emphasize the science concept they have used and deepen the discussion.

\section{M.4.1 The First Mission}

The first mission is collection information about the Moon Station. The children will get message from the commander asking them to measure distances between the bases. More specifically, he is asking the length of the black line between the bases. Moreover, he added diameters of three tiers of robots to his message.

To accomplish this mission the children should fill three blanks area on the Moon Station plan (similar to Figure M.2) representing the distance between base - power control unit, power control unit - reactor and rector - base. When they correctly filled the blanks and send, they could pass to next mission.

The children should be warned about not to do "trial and error", because each incorrect send will be evaluated by their commander as unsuccessful at the mission.

\section{M.4.2 Extra Activity}

According to the children performance, they could ask a design a robot which measures how far the robots moved and shows on the NXT's screen like cars' odometers. Moreover, they could make it for different size of tires.

\section{M.4.3 The Second Mission}




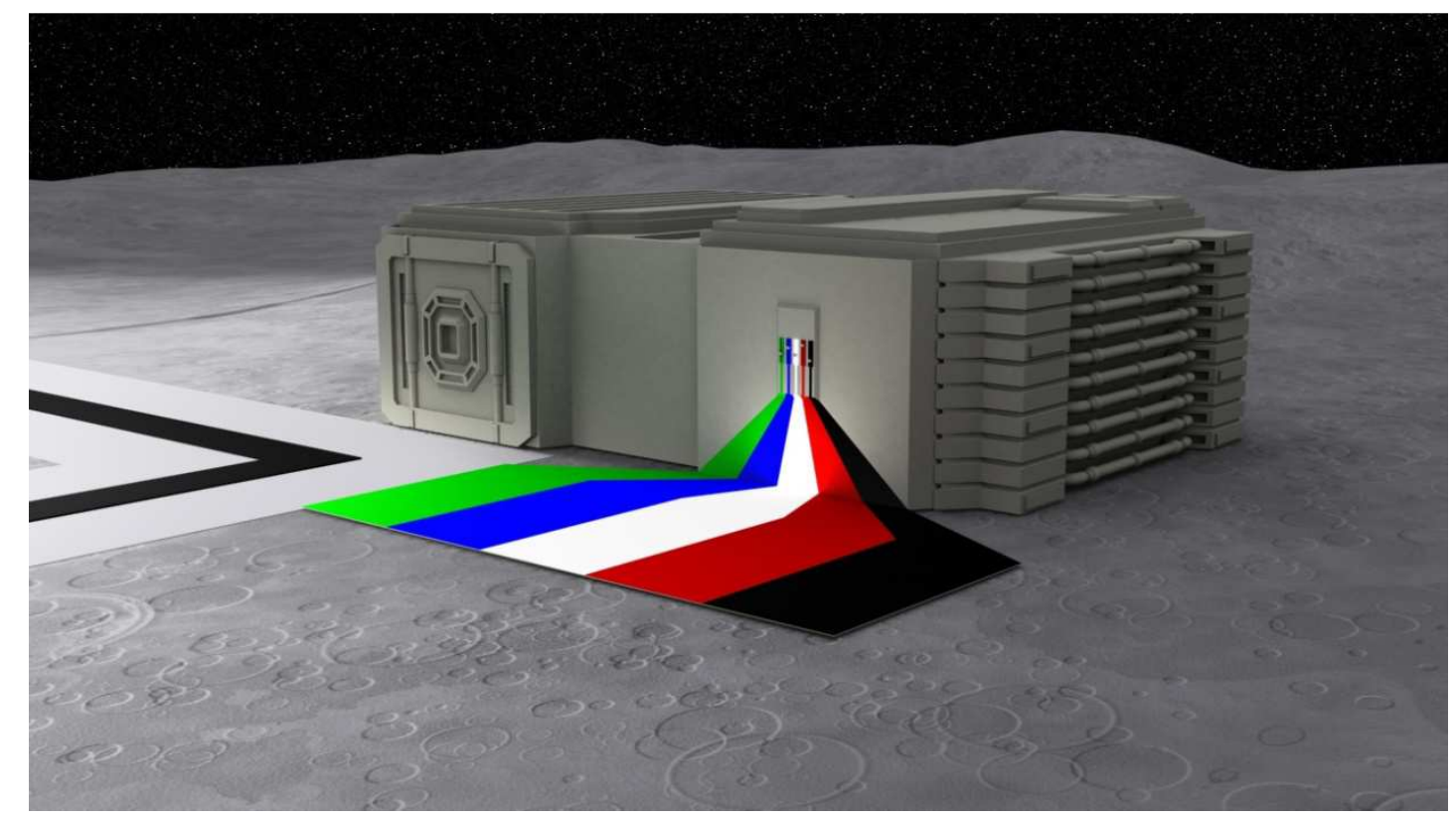

Figure M.3 Power Control Unit

The second mission is entering power control unit. Because of the radiation leak the reactor should be switched off. However, the power control unit is locked and could be opened only entering correct combination of a color based lock. The lock is work based on the reflection rate of the different colors.

After this briefing, the children will be directed to a web page, which contains five sliders on different colors (like Figure M.4). When they correctly arranged the sliders, they will see a short video showing the opening of the door and they could pass the next mission.

It is expected that, the children will measure the reflection rate of the different color on the work area. When they arrange the sliders on the web page, similar to the graph they will get on the NXT Data Logging screen, they will be achieved the mission. 


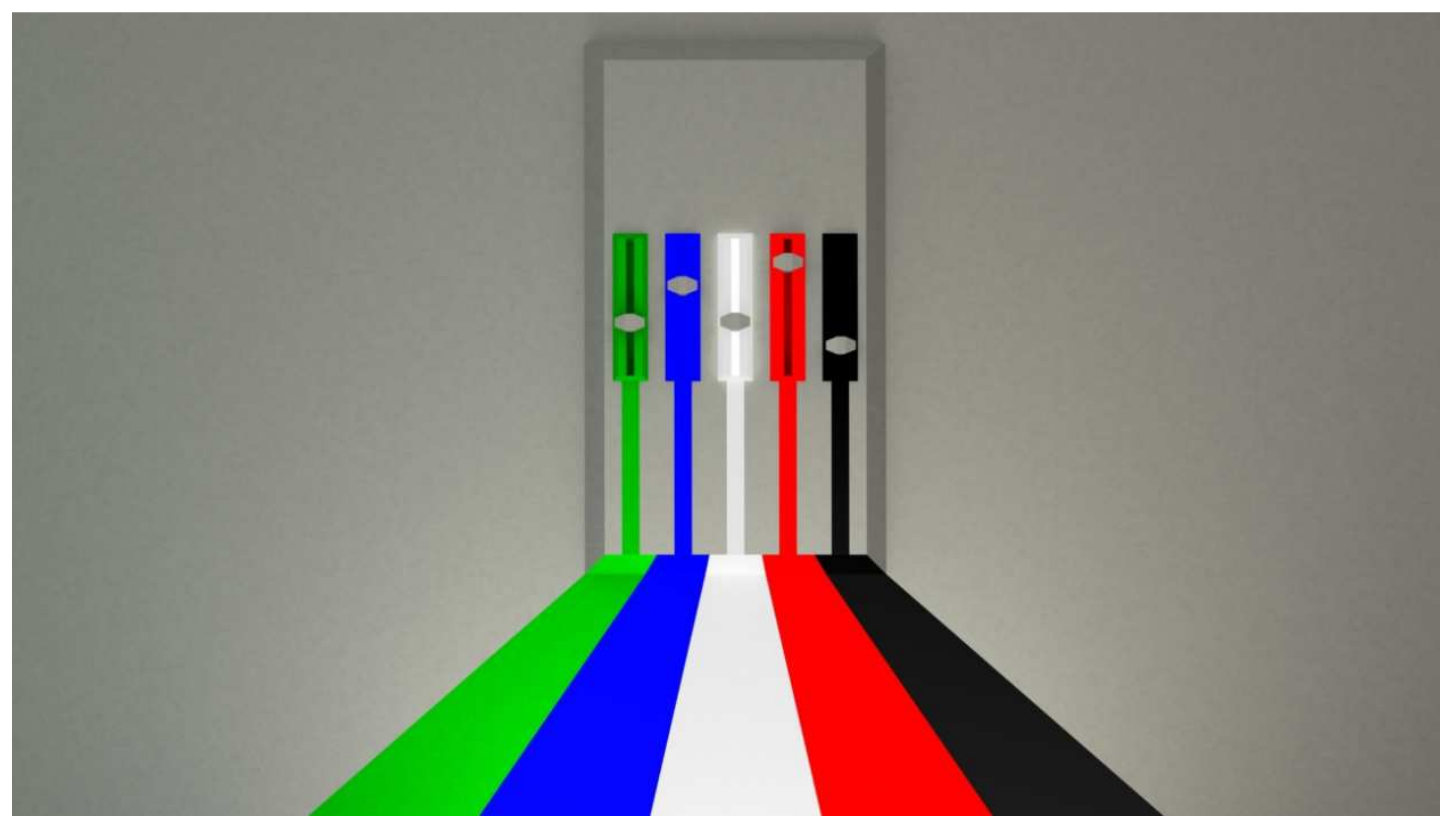

Figure M.4 Color lock

\section{M.4.4 The Third Mission}

The third mission is the finding the magnet. When power control unit opened, it realized that there is a problem inside of the unit and some parts of power control unit should be changed. The required parts sent inside a capsule from the earth. The capsule has landed on between power control unit and the rector. It is known that the capsule has a magnetic field like magnet.

The mission is finding the location of the capsule and getting it to base. However in this mission the robot with magnetic fields sensor will find the capsule and come to base. Then the grabber or arm connected robot should bring it to the base at the second time. When the capsule reached the base, the children should open it and get the code inside it to pass next mission.

\section{M.4.5 Extra Activity}

The children could measure density of the magnetic field along a magnet. How it changes $\mathrm{N}$ to $\mathrm{S}$ poles and discussed about their measurements. 


\section{M.4.6 The Fourth Mission}

The fourth mission is reach on time. When the part of the power control unit placed, it could not work properly. As a result of this malfunctioning, the doors of the bases could not work properly. When the door of main base opened, power control unit's door opens exactly ten seconds after it and it stays open exactly twenty seconds. Then, the reactor's door opens exactly twenty seconds after the power control unit's door closed. The reactor's door stays open thirty seconds. Thirty seconds later than the reactor's door closed, main base's door will be open. The children should program their robots to reach each base at stated time intervals.

One instructor will use a chronometer to measure time intervals and evaluate the robots performance. Moreover, the children could adjust and measure their robots velocity outside of the work area with a ruler and chronometer.

\section{M.4.7 Extra Activity}

This mission can be done with different size tires.

\section{M.4.8 The Fifth Mission}

The last mission is collecting supply containers. Three supply containers have been sent from the earth and the containers have landed randomly inside of the triangle area. The mission is collecting these containers and bringing them to the base. The children should program to their robots to find a container and bring it to the base, therefore they send their robots three times to achieve this mission. Each container has unique number, when the children enter these numbers into the web page they will be accomplished their mission.

\section{M.5 The Seventh, Eighth and Ninth Days}

These three days reserved for the project work. Like both camps, the children will design and program their robots to produce a solution for their daily life problems or a social problem. The instructor should behave like an adviser to guide their project work. 


\section{M.6 The Last Day}

On the last day of the camp, the children will present their robots and show their robots performance to the visitors. At the morning session children will prepare their presentation. The parents will be invited to the afternoon session of the camp to see what their children have achieved.

\section{M.7 Extra Activity - Tournament}

Because the curriculum has not been tested with sixth grade children, how long the missions will take is not known. If the children finished all missions, before the expected time, a tournament could be arranged to fill the time gap.

Aim of the tournament is designing strongest robots. Two robots will be connected to each other and placed center of a circle. Which robot drags competitor to the outside of the circle will be winner. After the semi-final and final the champion robots will be selected. After the selection of the champion, there will be a discussion on design consideration for the strongest robot. "How should be gears used?" "What is the importance of the tires' diameter?" "What is the importance of the number of the motors?" are should be main points of the discussion. Same tournament could be also arranged for the fastest robot. 


\section{CURRICULUM VITAE}

\section{PERSONAL INFORMATION}

Surname, Name: Üçgül, Memet

Nationality: Turkish (TC)

Place of Birth: Adana

Marital Status: Single

Phone: +903122104177

email: memet3gul@gmail.com

\section{EDUCATION}

$\begin{array}{lll}\text { Degree } & \text { Institution } & \text { Year of Graduation } \\ \text { MS } & \begin{array}{l}\text { METU Computer Education and } \\ \text { Instructional Technology }\end{array} & 2006 \\ \text { BS (Major) } & \begin{array}{l}\text { METU Computer Education and } \\ \text { Instructional Technology }\end{array} & 2003 \\ \text { BS (Minor) } & \text { METU Psychology } & 2003\end{array}$

WORK EXPERIENCE

\begin{tabular}{lll} 
Year & Place & Enrollment \\
$2010-2011$ & $\begin{array}{l}\text { Young Inventors Build Robots and } \\
\text { Discover Science (TUBITAK) }\end{array}$ & Instructor \\
$2004-2010$ & $\begin{array}{l}\text { METU Faculty of Education } \\
\text { Educational Volunteers Foundation } \\
\text { of Turkey (TEGV) }\end{array}$ & Research Assistant \\
\hline 2010 & Volunteer
\end{tabular}

FOREIGN LANGUAGE

Advanced English

INTERNATIONAL REPORT

Ucgul, M., Uslu, O. (2010). Development of Game Motivation Scale. 9th International Internet Education Conference \& Exhibition, 14-16 September, Cairo, Egypt, 2010. 